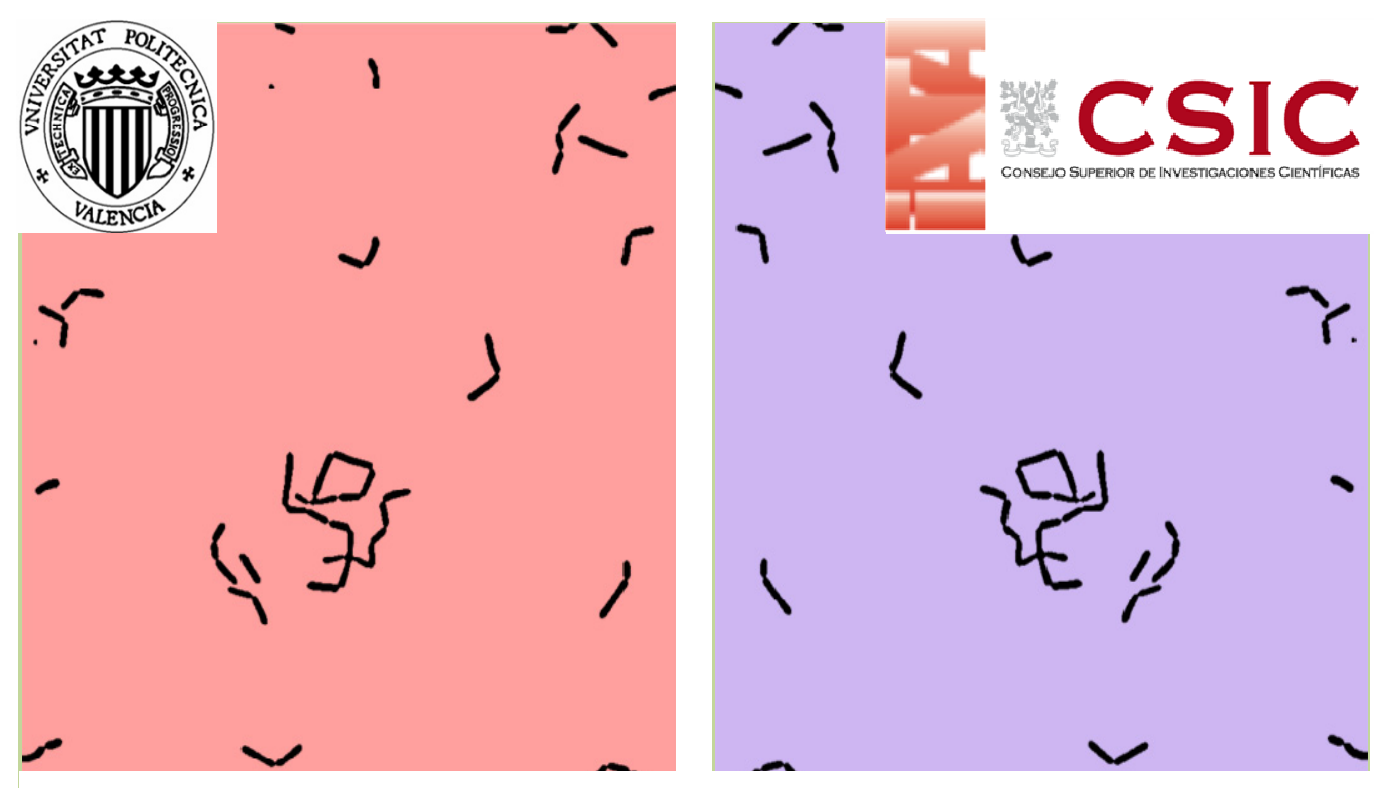

Caracterización de factores de adhesión a proteínas de la matriz extracelular en

\title{
Lactobacillus casei
}

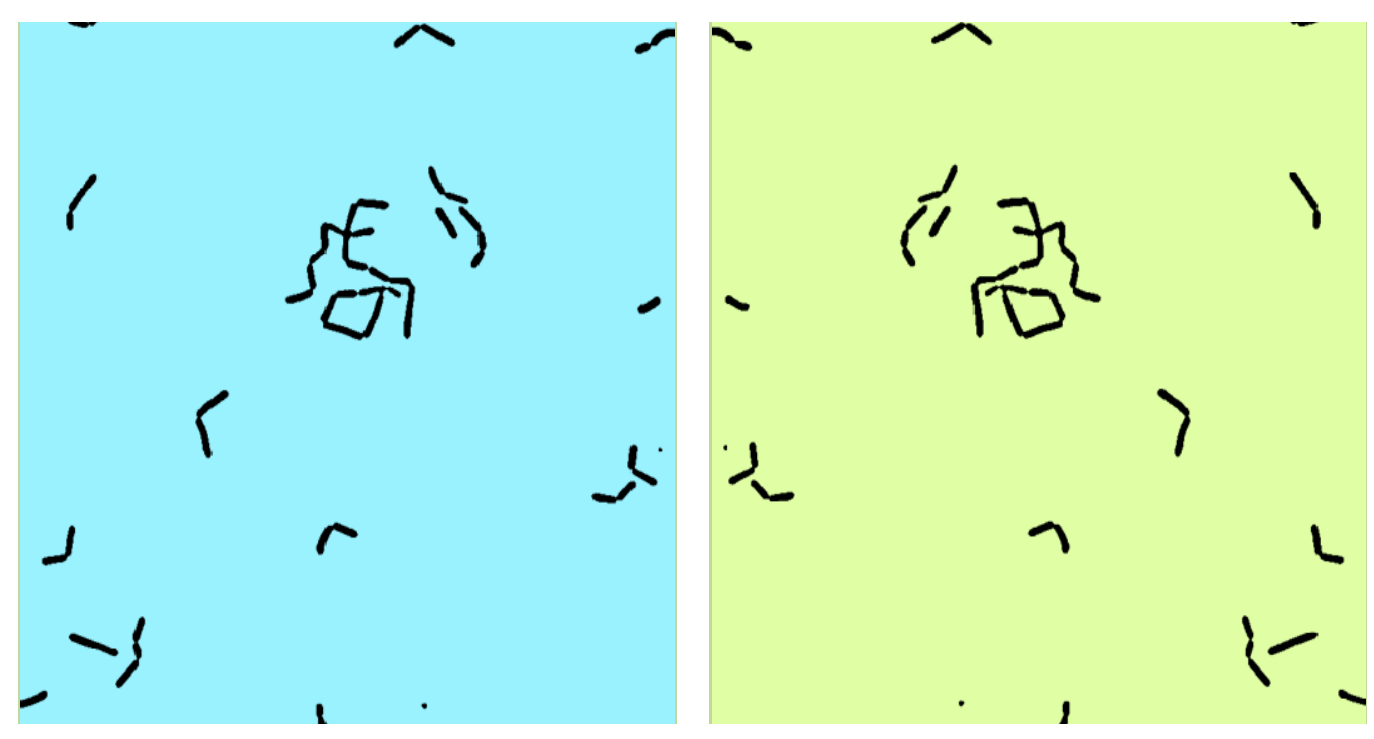

Diego Muñoz Provencio

Tesis Doctoral

Director de Tesis: Vicente Monedero García Septiembre, 2011. 


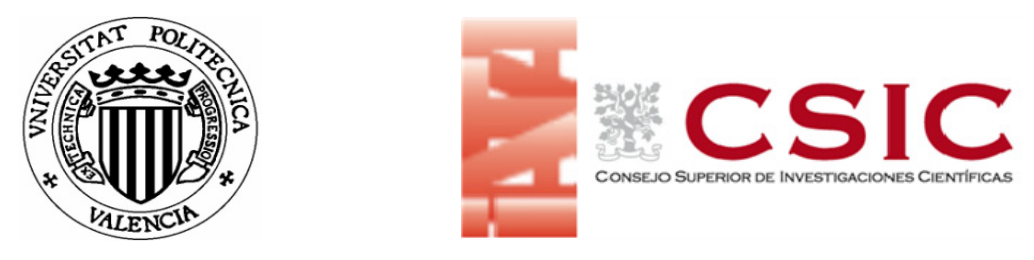

\author{
Universidad Politécnica de Valencia \\ Departamento de Biotecnología
}

Consejo Superior de Investigaciones Científicas

Instituto de Agroquímica y Tecnología de Alimentos

\title{
"Caracterización de factores de adhesión a proteínas de la matriz extracelular en Lactobacillus casei"
}

Memoria presentada por Diego Muñoz Provencio

para optar al grado de Doctor por la Universidad Politécnica de Valencia.

Director de Tesis: Vicente Monedero García 


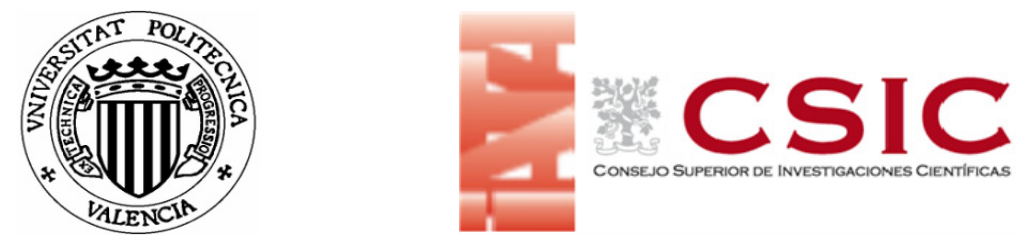

El Dr. Vicente Monedero García, Científico Titular del Laboratorio de Bacterias Lácticas y Probióticos, del Instituto de Agroquímica y Tecnología de Alimentos (IATA), Consejo Superior de Investigaciones Científicas (CSIC)

\section{CERTIFICA:}

Que la memoria titulada "Caracterización de factores de adhesión a proteínas de la matriz extracelular en Lactobacillus casei" presentada por el licenciado Diego Muñoz Provencio para optar al grado de doctor por la Universidad Politécnica de Valencia, ha sido realizada en el Instituto de Agroquímica y Tecnología de Alimentos (IATACSIC) bajo mi dirección y que reúne las condiciones necesarias para ser defendida por su autor ante el tribunal correspondiente.

Valencia, Septiembre 2011

Fdo.: Dr. Vicente Monedero García 



\section{AGRADECIMIENTOS}

Lo que estáis leyendo no son los agradecimientos originales. Acabaron siendo demasiado buenos, notablemente más largos de lo normal y de una escandalosa incorrección política. Por el momento duermen el sueño de los justos en un cajón y me los guardo como apuntes para una novela.

Agradezco a la Generalitat Valenciana que tuviera a bien otorgarme una beca FPI y al Instituto Danone la concesión de una beca de investigación sin las cuales hubiera debido hacer la tesis simplemente por amor al arte y viviendo debajo de un puente. Mi familia tiene mis agradecimientos por descontado, son mi grupo de apoyo, me impulsan a seguir.

Sin Vicente, mi director de tesis, nada de esto hubiera sido posible (GRACIAS con mayúsculas). Gracias también a mis tutores, Javier Buesa y Manuel Hernández, pese a que solo les vi fugazmente sé que me hubieran ayudado de haberlo requerido. Gracias a Gaspar que fue el primero con el que me puse en contacto y que inició la cadena de acontecimientos que me llevaron a este laboratorio.

Del periodo neurocientífico y cinematográfico debo dar las gracias a Víctor Meseguer, un amigo de los que siempre están cuando los necesitas, a Rodolfo Madrid que siempre se portó muy bien conmigo y a Neus Ayuso que me acogió en su casa como a alguien de su familia.

Agradezco a todo el personal del IATA el buen trato recibido. En especial aprecio mucho el momento “ $\mathrm{iHola}$, hola!” diario de Emilia y las conversaciones con Fran, Miguel y Alí.

De los mandamases no citados ya en el primer párrafo, debo dar las gracias a Ma Jesús por darme esos buenos kilos de limones cada año y a Manolo por ayudarme a poner en hora el reloj con su puntualidad britanica.

Le doy las gracias a Juan, Luisa, Sneyder, Adriana, Christine y Carmen que me permitieron adaptarme fácilmente al lugar al empezar la tesis. 
Christine se merece una mención especial; es con la que más tiempo he coincidido y me ha ayudado siempre que me ha hecho falta.

A Lourdes y Maite les agradezco su facilidad para transmitir alegría, a Pepe lo fácil que es llevarse bien con él y a Ahmed que siempre se acuerde de mí cuando vuelve en su peregrinaje intermitente. A Inma, Amparo, María y Pascual les agradezco el que siempre me recibieran con una sonrisa.

A Cristina, Chema, Ainhoa y Amalia les doy las gracias por constituir el ecosistema único del laboratorio 007. A los dos primeros por sus consejos y buen humor, a la tercera por sus ratos buenos y a la cuarta por ser como mi mami en el laboratorio.

Gracias a Jesús por intentar lo del Biacore conmigo, pese a que no saliera y a Maricarmen por ayudarme con los cultivos celulares y la historia de las sortasas.

Gracias a Arlette por ser mi amiga pese a que no soy proclive a hablar por teléfono y mis ganas son inversamente proporcionales a la duración de la conversación. Gracias también a los ratones que se dejaron pinchar -muy a su pesar-para que pudiéramos obtener antisueros.

En resumen les doy las gracias a todas las personas que quiero y a todas aquellas personas que me quieren, dos conjuntos que si bien no siempre son $100 \%$ coincidentes si son en su mayor parte solapantes. 


\section{RESUMEN}

El interés por los microorganismos probióticos se ha visto incrementado considerablemente en las últimas décadas. Se trata principalmente de aislados intestinales obtenidos de individuos sanos que administrados por vía oral contribuyen al mantenimiento de la homeostasis intestinal. Su efecto beneficioso es dependiente de las interacciones que lleven a cabo en el tracto gastrointestinal con células del epitelio, del sistema linfoide asociado a la mucosa y de otros miembros de la microbiota. La capacidad de adhesión a componentes de la mucosa gastrointestinal contribuiría a prolongar la permanencia y la posibilidad de que las citadas interacciones tengan lugar. Es por ello uno de los criterios más empleados para la selección de cepas potencialmente probióticas.

Los mecanismos de adhesión se han caracterizado principalmente en microorganismos patógenos donde juegan un papel clave en la invasión y colonización del huésped. Se considera que las bacterias probióticas podrían compartir algunos de estos mecanismos con las patógenas, pero sin embargo la disponibilidad de información acerca del proceso y de las moléculas implicadas es mucho menor. Este trabajo pretende profundizar en el estudio de las propiedades adhesivas de lactobacilos y en la caracterización de los determinantes implicados.

Lactobacillus casei es una especie presente de forma natural en el tracto gastrointestinal y reproductivo de animales y humanos, empleada tradicionalmente para la obtención de alimentos fermentados y que abarca múltiples cepas consideradas probióticas. La investigación llevada a cabo en esta tesis evidenció la ausencia de perfiles de adhesión claros en función del origen de la cepa, existiendo una gran variabilidad intra-específica. Los tratamientos con proteasas sugirieron una contribución mayoritaria de factores proteicos expuestos en superficie en la adhesión a proteínas de la matriz extracelular.

Empleamos la cepa de L. casei BL23 por su carácter probiótico, la susceptibilidad a ser manipulada genéticamente y la disponibilidad de su secuencia genética. La identificación de posibles adhesinas proteicas se abordó por tres estrategias complementarias: análisis in silico, búsqueda en una genoteca de phage display e identificación directa a partir de extractos de proteínas de pared. 
Se determinaron las propiedades de adhesión de las proteínas purificadas y el efecto que la mutación puntual de los genes codificantes tenía sobre las propiedades adhesivas de las células enteras.

La variedad de proteínas identificadas capaces de interaccionar con componentes de la matriz extracelular refuerza la idea de que el proceso de adhesión es multifactorial. Posiblemente estas proteínas posean características de tipo lectina ya que las proteínas del mucus y de la matriz extracelular se caracterizan por estar altamente modificadas, principalmente por glicosilación.

Una parte de las posibles adhesinas identificadas habían sido previamente caracterizadas como proteínas intracelulares con una función no relacionada con adhesión (enzimas glicolíticas, proteínas implicadas en respuesta a estrés, etcétera). Son proteínas moonlighting que no seguirían las vías clásicas de secreción de proteínas o anclaje a la superficie celular.

Este trabajo también trató de investigar la posible contribución a la persistencia en el nicho gastrointestinal de proteínas ancladas a superficie por acción de las enzimas sortasas, encontrando sustratos que estarían implicados en la utilización de carbohidratos de la mucosa y en adhesión a la misma. Se identificaron cuatro sortasas, dos de la clase A y dos de la clase C. Los estudios de las propiedades de adhesión, de anclaje de sustratos con motivo reconocible por sortasas y de la expresión génica apuntaron a que srtA1 sería responsable del anclaje de la mayoría de los sustratos con motivo reconocible por sortasas mientras que srtA2 podría compensar la ausencia de actividad srtA1.

Los clusters de srtC1 y srtC2 son homólogos de los clusters spaFED y spaCBA de $L$. rhamnosus GG responsables de la formación de pili con capacidad de adherir mucus intestinal lo que sugería que L. casei se trataría de una bacteria con este tipo de apéndices proteicos que podrían contribuir a la adhesión al mucus.

Este trabajo ha supuesto un incremento del conocimiento acerca de las propiedades adhesivas de $L$. casei a componentes de la mucosa gastrointestinal y de factores proteicos implicados en la interacción huésped/probiótico. 
RESUM:

L'interès pels microorganismes probiòtics s'ha vist incrementat considerablement durant les darreres dècades. Es tracta principalment d'aïllats intestinals obtinguts d'individus sans que quan son administrats per via oral contribueixen al manteniment de I'homeostasis intestinal. El seu efecte beneficiós és dependent de les interaccions que porten a terme al tracte gastrointestinal amb les cèl-lules de l'epiteli, del sistema limfoide associat a la mucosa i d'altres membres de la microbiota. La capacitat d'adhesió a components de la mucosa gastrointestinal contribuiria a perllongar la permanència $i$ la posibilitat de què les esmentades interaccions esdevinguen. Degut a aquest fet, és un dels criteris més utilitzats per a la selecció de soques potencialment probiòtiques.

Els mecanismes d'adhesió s'han caracteritzat principalment a microorganismes patògens en els quals desenvolupen un paper clau durant la invasió i la colonització de l'hoste. Es considera que els bacteris probiòtics podrien compartir alguns d'aquests mecanismes amb els patògens, no obstant això la disponibilitat d'informació sobre el procés i de les molècules implicades és molt menor. Aquest treball d'investigació pretén profunditzar en l'estudi de les propietats adhesives dels lactobacils i en la caracterització dels determinants implicats.

Lactobacillus casei és una espècie present de forma natural en el tracte gastrointestinal i reproductiu d'animals i d'humans, utilitzada tradicionalment per a l'obtenció d'aliments fermentats i que compren múltiples soques considerades probiòtiques. L'investigació realitzada en aquesta tesi va evidenciar l'absència de perfils d'adhesió clars en funció de l'origen de la soca, existint una gran variabilitat intra-específica. Els tractaments amb proteases van suggerir una contribució majoritària de factors proteïcs exposats a la superfície en l'adhesió a proteïnes de la matriu extracel/lular.

Vam emprar la soca de L. casei BL23 pel seu caràcter probiòtic, la susceptibilitat a ser manipulada genéticament i la disponibilitat de la seva seqüència genètica. La identificació de possibles adhesines proteiques es va abordar mitjançant tres estratègies complementàries: anàlisi in silico, recerca a una genoteca de phage display i la identificació directa a partir d'extractes de proteïnes de paret. 
Es van determinar les propietats d'adhesió de les proteïnes purificades i l'efecte que la mutació puntual dels gens codificants tenia sobre les propietats adhesives de les cèl-lules senceres.

La diversitat de proteïnes identificades capaces d'interaccionar amb components de la matriu extracel-lular reforça la idea de què el procés d'adhesió és multifactorial. Possiblement aquestes proteïnes posseeixin característiques de tipus lectina degut a què les proteïnes del mucus i de la matriu extracel-lular es caracteritzen per estar altament modificades, principalment per la glicosilació.

Algunes de les possibles adhesines identificades havien estat prèviament caracteritzades com a proteïnes intracel/lulars, amb una funció no relacionada amb l'adhesió (enzims glicolítics, proteïnes implicades en la resposta a estrès, etcètera). Són proteïnes moonlighting les quals no seguirien les vies clàssiques de secreció de les proteïnes o d'ancoratge a la superfície cel-lular.

Aquest treball també va tractar d'investigar la possible contribució a la persistència al nínxol gastrointestinal de proteïnes ancorades a la superfície per acció dels enzims sortases, trobant substrats que estarien implicats en la utilització de carbohidrats de la mucosa i en l'adhesió a la mateixa. Es van identificar quatre sortases, dues de la classe $\mathrm{A}$ i dues de la classe $\mathrm{C}$. Els estudis de les propietats d'adhesió, d'ancoratge de substrats amb motiu reconeixible per les sortases i de l'expressió gènica, apuntaven en el sentit què srtA1 seria responsable de l'ancoratge de la majoria dels substrats amb motiu reconeixible per les sortases mentrestant srtA2 podria compensar l'absència d'activitat srtA1.

Els clusters de srtC1 i srtC2 són homòlegs dels clusters spaFED i spaCBA de L. rhamnosus GG responsables de la formació de pili amb capacitat d'adherir mucus intestinal, la qual cosa suggeria que $L$. casei es tractaria d'un bacteri amb aquest tipus de apèndixs proteics que podrien contribuir a l'adhesió al mucus.

Aquest treball ha suposat un increment del coneixement en torn a les propietats adhesives de $L$. casei a components de la mucosa gastrointestinal i de factors proteics implicats en la interacció hoste/probiòtic. 
ABSTRACT:

The interest on probiotic microorganisms has increased considerably during the last decades. They are mainly intestinal isolates obtained from healthy individuals that when orally administered contribute to the intestinal homeostasis maintenance. Their beneficial effect depends on the interactions they carry out in the gastrointestinal tract with cells of the epithelium, the mucosa associated lymphoid tissue and other microbiota members. The adhesion capacity to gastrointestinal mucosa components would prolong their persistence and increase the possibility that these interactions take place. These reasons make it one of the most employed criterium for the selection of potential probiotic strains.

The adhesion mechanisms have been characterized mainly in bacterial pathogens, where they play a key role in the invasion and colonization of the host. It is considered that the probiotic bacteria would share some of the mechanisms present in pathogens, but the availability of information about the process and the molecules implicated is still limited for this group of microorganisms. This work aimed to deepen in the study of the lactobacilli adhesive properties and in the characterization of the determinants implicated.

Lactobacillus casei species is naturally present in the gastrointestinal and reproductive tracts of humans and animals, it has been traditionally used to obtain fermented foods and it encompasses multiple strains considered as probiotics. The research carried out in this thesis evidenced the absence of clear adhesion profiles depending on the strain origin and a great intra-specific variability. The protease treatment suggested a major contribution of surface exposed proteic factors in the adhesion to extracellular matrix (ECM) proteins.

We employed the L. casei BL23 strain due to its probiotic character, its genetic manipulation susceptibility and the availability of its genome sequence.

The identification of possible proteic adhesins was carried out by three complementary strategies: in silico analysis, the search on a phage display gene library and the direct identification using cell wall protein extracts. We determined the adhesive properties of the purified proteins and the effect of mutations of their codifying genes on the adhesive properties of whole cells. 
The variety of proteins able to interact with ECM components identified reinforces the idea that the adhesion proccess is multifactorial. They possibly have lectin-like characteristics since the mucus and ECM proteins are characterized by being highly modified, mainly by glycosylation. Part of the potential adhesins identified have been previously characterized as intracellular proteins with a main function not related to adhesion (glicolytic enzymes, stress response proteins, etc.) Therefore, they represent moonlighting proteins that would not follow the classic pathways of secretion or anchoring to the cell surface.

This work also aimed to determine the possible contribution of sortase-dependent surface proteins to the persistence in the gastrointestinal tract. We found substrates implicated in mucosal carbohydrate utilization and mucosal adhesion. Four sortases were identified in L. casei BL23, two class A (srtA1 and srtA2) and two class C sortases (srtC1 and srtC2) clustered with their potential substrates. The studies of adhesion properties, sortase dependent substrate anchoring and gene expression pointed to srtA1 as the main sortase responsible of anchoring the majority of substrates with sortase cleavage motif, while srtA 2 may compensate the absence of srtA1 activity. srtC1 y srtC2 clusters are, respectively, homologous to the spaFED and spaCBA clusters of $L$. rhamnosus GG responsible for the formation of pili with intestinal mucus adhesive capacity. This suggests that $L$. casei would be a bacterium with this kind of proteic appendixes that may contribute to the mucus adhesion.

This thesis represents an increase in the knowledge of the $L$. casei adhesive properties to components of the gastrointestinal mucosa and of the proteic factors implicated in the host/probiotic interaction. 


\section{ÍNDICE}

\section{INTRODUCCIÓN GENERAL}

1. EL TRACTO GASTROINTESTINAL

2. MICROBIOTA DEL TRACTO GASTROINTESTINAL 3

3. DIVERSIDAD DE NICHOS EN EL INTESTINO 8

3.1 Estómago $\quad 8$

3.2 Intestino delgado

3.3 Intestino grueso 9

4. LA BARRERA MUCOSA DEL INTESTINO 10

4.1 Capa de mucus $\quad 10$

4.2 Epitelio intestinal $\quad 11$

4.3 Tejido conectivo (membrana basal y lamina propria) 13

4.3.1 Colágeno de tipo IV 15

4.3.2 Laminina $\quad 15$

4.3.3 Fibronectina $\quad 15$

4.3.4 Fibrinógeno 16

4.3.5 Colágenos de tipo fibrilar $\quad 16$

4.4 Tejido linfoide asociado a la mucosa gastrointestinal 16

5. BACTERIAS LÁCTICAS 19

5.1 Lactobacillus casei 20

6. PROBIÓTICOS, PREBIÓTICOS Y SIMBIÓTICOS

7. CONTRIBUCIÓN DE LOS PROBIÓTICOS A LA FUNCIÓN BARRERA INTESTINAL 24

7.1 Efectos sobre el epitelio $\quad 25$

7.1.1 Incrementando la secreción de mucus por las células $\quad 25$ caliciformes

7.1.2 Produciendo ácidos grasos de cadena corta 26

7.1.3 Incrementando la secreción de péptidos 27 antimicrobianos ( $\beta$-defensinas) por parte de los enterocitos

7.1.4 Favoreciendo la estabilidad de las uniones estrechas $\quad 28$ disminuyendo la permeabilidad epitelial a

patógenos o sus productos

7.1.5 Promoviendo la homeostasis intestinal a través de $\quad 29$ rutas de señalización específicas

7.2 Efectos sobre el sistema inmune asociado a mucosas 30

7.2.1 Incrementando el número de células productoras de $\quad 30$ inmunoglobulina $A$ en la lámina propia

7.2.2 Promoviendo la secreción de la IgA al mucus luminal $\quad 31$

7.3 Efectos sobre otros miembros de la microbiota 31

7.3.1 Compitiendo por sitios de unión con comensales o 31 patógenos 
determinados miembros de la microbiota beneficiosos para el hospedador

7.3.4 Matando (efecto bactericida) o inhibiendo el crecimiento (efecto bacteriostático) de bacterias patógenas al liberar factores antimicrobianos como las bacteriocinas

8. PROCESO DE ADHESIÓN EPITELIAL

10.1 Pared celular

10.1.1 Peptidoglicano

10.1.2 Ácidos teicoicos

10.1.3 Polisacáridos de pared

10.1.4 Proteínas de superficie

10.1.4.1 Proteínas unidas a la membrana por inserción de segmentos hidrofóbicos

10.1.4.2 Lipoproteínas

10.1.4.3 Proteínas ancladas covalentemente a pared por acción de las sortasas

10.1.4.4 Anclaje no covalente por dominios específicos que reconocen algún componente de la pared (CWBD1, CWBD2, LysM, GW, SLHD, WxL, $\mathrm{SH} 3 \mathrm{~b})$

10.1.4.5 Moonlighting proteins

11. SISTEMAS DE SECRECIÓN DE PROTEÍNAS EN LACTOBACILOS

11.2 Holin (Formador de poros)

11.3 (Fimbrilin-Protein Exporter)

11.4 Peptide Efflux ABC Transporters

12.1 Proteínas de unión a mucus

12.2 Proteínas de la capa de superficie (S-layer) como adhesinas

12.3 Proteínas que median la adhesión a la matriz extracelular 
CAPÍTULO 1: Adhesion properties of Lactobacillus casei strains to resected intestinal fragments and components of the extracellular matrix.

\begin{tabular}{|c|c|}
\hline ABSTRACT & 82 \\
\hline INTRODUCTION & 83 \\
\hline MATERIALS AND METHODS & 85 \\
\hline Strains and growth conditions & 85 \\
\hline Adhesion to solvents test & 86 \\
\hline Ex vivo binding assay & 86 \\
\hline Microtitre plate binding assays & 88 \\
\hline Yeast agglutination assay & 89 \\
\hline Bioinformatic analysis & 89 \\
\hline RESULTS & 90 \\
\hline Adhesion properties to solvents & 90 \\
\hline Binding to human colon fragments ex vivo & 92 \\
\hline In vitro binding to mucin and $\mathrm{ECM}$ components & 93 \\
\hline DISCUSSION & 100 \\
\hline ACKNOWLEDGEMENTS & 104 \\
\hline REFERENCES & 105 \\
\hline $\begin{array}{l}\text { 2 2: Characterization of a fibronectin-binding protein from } \\
\text { illus casei BL23 }\end{array}$ & 109 \\
\hline ABSTRACT & 112 \\
\hline INTRODUCTION & 113 \\
\hline MATERIALS AND METHODS & 115 \\
\hline Strains and growth conditions & 115 \\
\hline Construction of an L. casei BL23 fbpA mutant & 115 \\
\hline Microtitre plate binding assays & 117 \\
\hline Adhesion to solvents test & 118 \\
\hline Adhesion to Caco-2 and HT-29 cell lines & 119 \\
\hline Purification of $6 \mathrm{X}(\mathrm{His}) \mathrm{FbpA}$ and binding assays & 119 \\
\hline Preparation of antiserum to $6 \mathrm{X}(\mathrm{His}) \mathrm{FbpA}$ & 120 \\
\hline Isolation of cellular fractions and western blot & 121 \\
\hline Statistical analysis. & 121 \\
\hline
\end{tabular}

CAPÍTULO 2: Characterization of a fibronectin-binding protein from 
Characterization of an L. casei BL23 strain mutated in fbpA 122

L. casei FbpA binds to fibronectin $\quad 126$

Cellular location of FbpA $\quad 128$

FbpA in other L. casei strains $\quad 129$

DISCUSSION 132

ACKNOWLEDGEMENTS $\quad 135$

REFERENCES 136

CAPÍTULO 3: Shotgun phage display of Lactobacillus casei BL23 against 139 collagen and fibronectin

$\begin{array}{lr}\text { ABSTRACT } & 142 \\ \text { INTRODUCTION } & 143 \\ \text { MATERIALS AND METHODS } & 145 \\ \text { Strains and growth conditions } & 145 \\ \text { Construction and screening of an L. casei BL23 shotgun } & 145 \\ \text { phage-display library } & \\ \text { ELISA of individual clones } & 147 \\ \text { Protein expression and purification } & 147 \\ \text { In vitro binding assays } & 148 \\ \text { RT-PCR } & 149 \\ & 150 \\ \text { RESULTS } & 150 \\ \text { and fibronectin by phage display } & 153 \\ \text { Ability of purified XpkR, ps356 and LCABL_01820 to bind } & 155 \\ \text { collagen and fibronectin } & 156 \\ \quad \text { Expression of } x p k R, p s 356 \text { and LCABL_01820 in L. casei } & 158 \\ \text { BL23. } & 159\end{array}$

CAPÍTULO 4: Identification of surface proteins from Lactobacillus casei BL23 163 able to bind fibronectin and collagen

\begin{tabular}{ll} 
ABSTRACT & 166 \\
INTRODUCTION & 167 \\
MATERIALS AND METHODS & 169 \\
\multicolumn{1}{c}{ Bacterial Strains and Growth Conditions } & 169 \\
$\quad$ Isolation of $L$. casei Surface Proteins and Immunoplate & 169
\end{tabular}

XII 
Purification of GST Fusion Proteins 170

Immunoplate Binding Assays with Purified Proteins $\quad 171$

RESULTS 172

L. casei BL23 Surface Proteins that Bind Fibronectin and 172

Collagen

Verification of Binding of Enolase and GAPDH 174

DISCUSSION 176

$\begin{array}{ll}\text { ACKNOWLEDGEMENTS } & 178\end{array}$

$\begin{array}{ll}\text { REFERENCES } & 179\end{array}$

CAPÍTULO 5: Four sortase genes are present in the genome of Lactobacillus 183

casei BL23. Mutant construction and characterization.

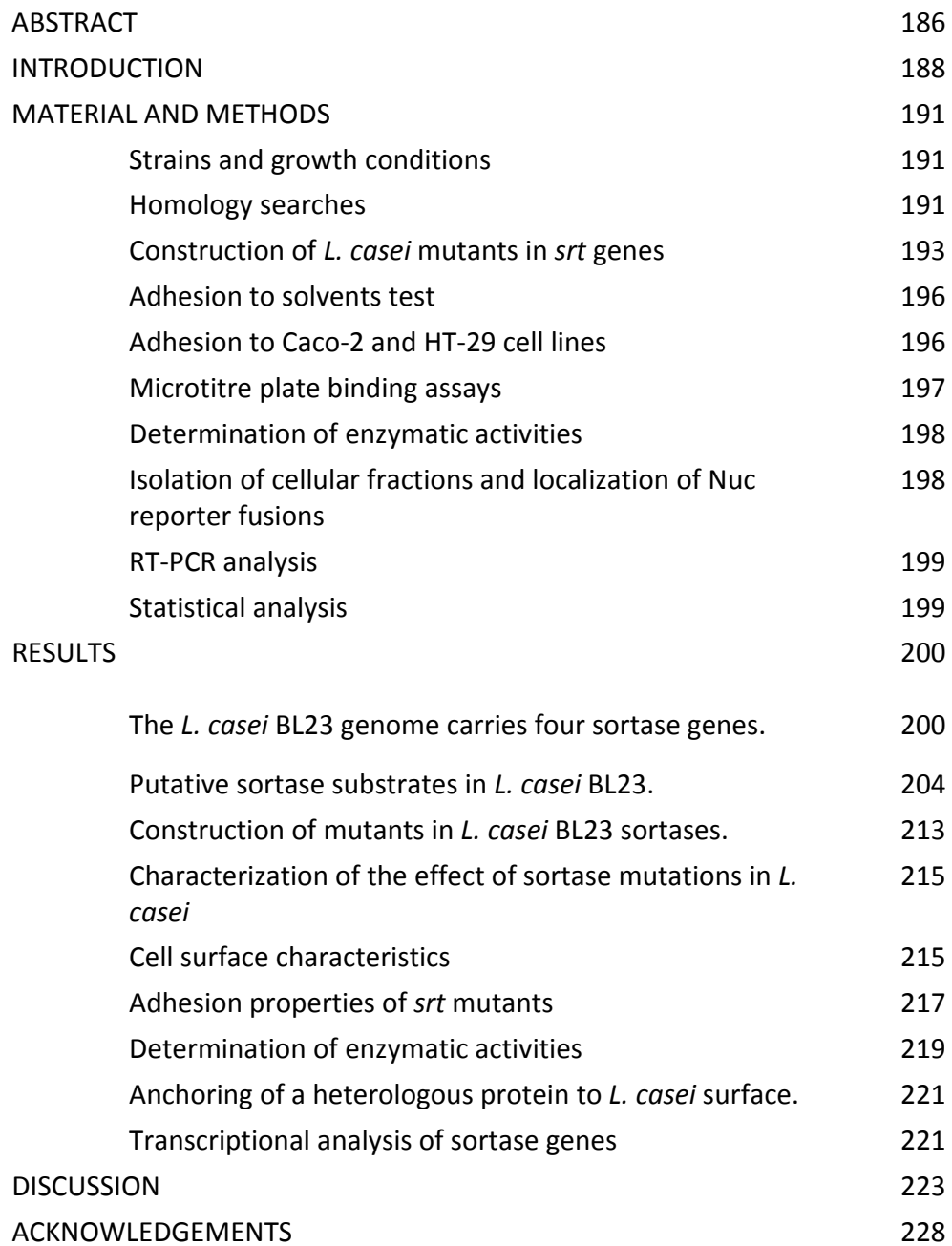

XIII 
DISCUSIÓN GENERAL

233

CONCLUSIONES FINALES

247 
INTRODUCCIÓN 
INTRODUCCIÓN 


\section{EL TRACTO GASTROINTESTINAL:}

El tracto gastrointestinal o aparato digestivo es un conjunto de órganos presente en animales pluricelulares cuyas funciones principales son la ingesta y digestión de alimentos, la absorción de nutrientes, la retención de agua y electrolitos, colaborar con la excreción, y desempeñar una serie de actividades que suponen una barrera frente a agresiones del ambiente externo (por ejemplo la neutralización de sustancias y microorganismos nocivos) (Shen, 2009). Si tuviéramos que resumir sus dos principales funciones serían nutrición y defensa (Hsiao, et al., 2008).

Su gran longitud en humanos (unos 11 metros), las plicae circulares o elevaciones regulares, las proyecciones en forma de dedo en que se disponen las células epiteliales o enterocitos y el borde apical en cepillo de éstas, conforman una superficie de más de 300 $\mathrm{m}^{2}$ siendo la zona principal de interacción con antígenos, microorganismos y sustancias potencialmente nocivas en el organismo.

\section{MICROBIOTA DEL TRACTO GASTROINTESTINAL:}

No vivimos en un entorno estéril, la colonización del tracto gastrointestinal comienza a las pocas horas de nacer. El modo de nacimiento, así como el contacto con la madre y el resto del personal responsable del cuidado del recién nacido determinan los microorganismos a los que éste se expone. Posteriormente, el principal reservorio de microorganismos y antígenos con el que se va a enfrentar el individuo es la dieta.

Durante los primeros años de vida, el tracto inmaduro y susceptible a desequilibrios experimenta una sucesión más o menos caótica de poblaciones hasta llegar a la microbiota (flora microbiana) intestinal del adulto (Palmer, et al., 2007), una colección de microorganismos que viven en coexistencia pacífica con su hospedador. 


\section{INTRODUCCIÓN}

Múltiples factores genéticos y ambientales influyen su composición, lo que da lugar a amplias variaciones entre individuos (Figura 1). La microbiota aumenta tanto en número de células como en diversidad hasta el año de edad, momento a partir del cual los números se mantienen esencialmente constantes produciéndose una evolución en su composición.

FACTORES GENÉTICOS DEL INDIVIDUO

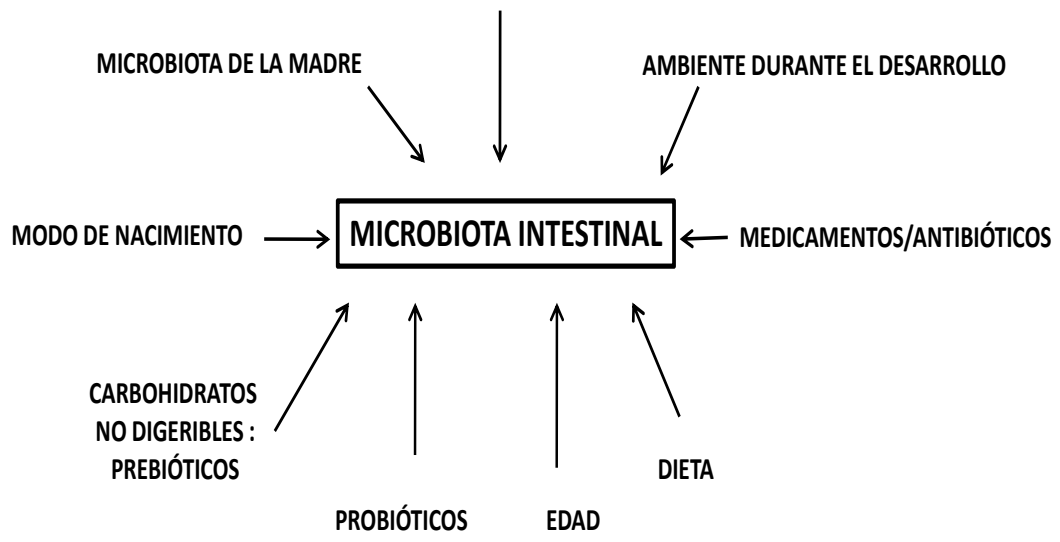

Figura 1. Factores que influyen sobre la composición de la microbiota intestinal. Adaptado de The intestine and its microflora are parterns for the protection of the host: report on the Danone Symposium "The Inteligent Intestine" (Bourlioux, et al., 2003).

El estudio de la diversidad de las poblaciones microbianas del intestino ha sido muy difícil de abordar pues los métodos tradicionales de cultivo bacteriano se han mostrado insuficientes, ya que se calcula que hasta un $80 \%$ de las especies no se pueden cultivar in vitro debido a que la gran mayoría son anaerobias estrictas y a que muchas tienen requerimientos físicos y nutricionales muy concretos (Duncan, et al., 2007).

Recientemente los estudios metagenómicos empleando técnicas independientes de cultivo, como la generación de genotecas de 16S DNA o la secuenciación masiva, han permitido identificar en torno a 1000 unidades taxonómicas operativas por individuo (Hamady \& Knight, 2009, Tap, et al., 2009). 
En éstas son mayoría las bacterias, destacando los filos Firmicutes y Bacteroidetes, pero también encontramos en cantidades pequeñas y variables otros filos bacterianos, arqueas, virus, hongos y protistas unicelulares (Marchesi, 2010).

Solo una pequeña proporción de los filos detectados en la biosfera han evolucionado en asociación con el intestino humano, como resalta el hecho de que se encuentren solo 9 filos bacterianos y 1 de arqueas de entre los más de 70 y los 13 conocidos respectivamente (Hsiao, et al., 2008).

Los lactobacilos, un género de microorganismos anaerobios facultativos perteneciente al filo Firmicutes, con una amplia presencia en productos alimentarios fermentados y con miembros considerados probióticos, presentan unos niveles bajos en el colon o en heces. Sin embargo son predominantes en el estómago y especialmente en el intestino delgado, pudiendo constituir hasta el $50 \%$ de la microbiota del ileon (Kleerebezem \& Vaughan, 2009).

Es de destacar que hay microorganismos que pese a pertenecer a los filos menos abundantes en el tracto gastrointestinal humano pueden tener una gran influencia en el mantenimiento de la salud y el desarrollo de la enfermedad. Como por ejemplo las proteobacterias entre las que se encuentran patógenos implicados como agentes etiológicos en el desarrollo de la colitis ulcerosa. Otro ejemplo, en este caso de microorganismos considerados probióticos, son las bifidobacterias, un genero de bacterias Gram-positivas anaerobias estrictas pertenecientes a los Actinomycetes que constituyen tan solo del 3 al $5 \%$ de la microbiota presente en el colon adulto (Duncan, et al., 2007).

Así, el tracto gastrointestinal humano se desvela como uno de los ecosistemas más complejos hasta ahora estudiados. La composición de la microbiota intestinal está recibiendo una atención creciente por su potencial implicación en desordenes funcionales del intestino e incluso en enfermedades no intestinales como la diabetes o el síndrome metabólico. 


\section{INTRODUCCIÓN}

El interés está en determinar si la composición de la misma varía conjuntamente con los marcadores de las enfermedades, no solo tomando dicha composición como indicativo de enfermedad, sino también de riesgo de padecerla y en consecuencia con utilidad en prevención (Mai \& Draganov, 2009).

El intestino se ha considerado de gran importancia en la salud humana, pues ya en el año 400 A.C. Hipócrates afirmaba "la muerte se asienta en los intestinos" o "la raíz del mal está en una mala digestión". En las últimas décadas la mayor parte de las investigaciones sobre la interacción de microorganismos con el intestino se han centrado en patógenos gastrointestinales y la forma en que causan enfermedad. Sin embargo recientemente ha aumentado de forma considerable el interés por el estudio del efecto de microorganismos comensales y de su compleja red de contribuciones a la fisiología del hospedador (Sekirov, et al., 2010).

Los animales gnotobióticos (raices griegas gnostos "conocido" y bios "vida"), son modelos reduccionistas, nacen y crecen en un entorno estéril para luego recibir un inoculo bacteriano de composición conocida. El conocer la composición de la microbiota posibilita estudiar los efectos de cepas bacterianas individuales o grupos definidos. Dichos modelos han permitido determinar que la microbiota intestinal no es indispensable, pero influye notablemente en aspectos anatómicos y fisiológicos (Hsiao, et al., 2008).

Los animales sin microbiota intestinal requieren un mayor aporte calórico para mantener su peso corporal (un $30 \%$ más en el caso de ratones), su motilidad intestinal y la tasa de regeneración del epitelio son más lentas que en un organismo convencional y, además, pueden presentar diferencias a nivel hepático, hormonal, inmune, de comportamiento y en el manejo de electrolitos y fluidos (Smith, et al., 2007).

La relación del hospedador con la microbiota del intestino es una simbiosis con importantes implicaciones para la nutrición, la fisiología y la regulación del sistema inmune del hospedador. 
Los microorganismos encuentran nutrientes y un ambiente estable, fermentan sustancias de otro modo indigeribles por el organismo y aportan, metabolitos como los ácidos orgánicos de cadena corta acetato y butirato, siendo este último el nutriente preferido por los colonocitos.

La microbiota puede alcanzar $10^{13}-10^{14}$ células; 10 veces más que las propias del hospedador y el microbioma o conjunto de sus genes ser 100 veces mayor (Gill, et al., 2006). La microbiota desempeña importantes funciones metabólicas que rivalizan con las del hígado, pudiendo ser considerada como un órgano virtual y el microbioma una extensión del genoma del hospedador (O'Hara \& Shanahan, 2006).

Por tanto, los seres humanos son super-organismos cuyo metabolismo está constituido por una amalgama de atributos humanos y microbianos.

Diversos estudios metagenómicos sugieren que el $80 \%$ o más de los microorganismos presentes en el intestino son específicos del hospedador aunque pueden identificarse en torno a un $2 \%$ de unidades taxonómicas operativas compartidas entre individuos que constituirían un núcleo común (Tap, et al., 2009). En la actualidad hay múltiples proyectos en marcha en todo el mundo para caracterizar el microbioma intestinal humano, como el MicrOBES (INRA. Francia) o el Meta-HIT (Unión Europea y China) e identificar dicho núcleo común dadas las implicaciones que para la salud tienen las disbiosis. Esto ha llevado recientemente a la determinación de la existencia en la población de tres "enterotipos" diferentes que que se distinguen en la estructura de las especies bacterianas presentes en el intestino (Arumugam, et al., 2011). Así, los datos sugieren la existencia de relaciones de simbiosis específicas entre las poblaciones bacterianas y el hospedador que estarían influenciadas por el genotipo y fenotipo de éste. 


\section{INTRODUCCIÓN}

\section{DIVERSIDAD DE NICHOS EN EL INTESTINO:}

La diversidad de nichos siguiendo el eje proximal-distal del tracto gastrointestinal condiciona una distribución no uniforme de la flora microbiana (Figura 2).

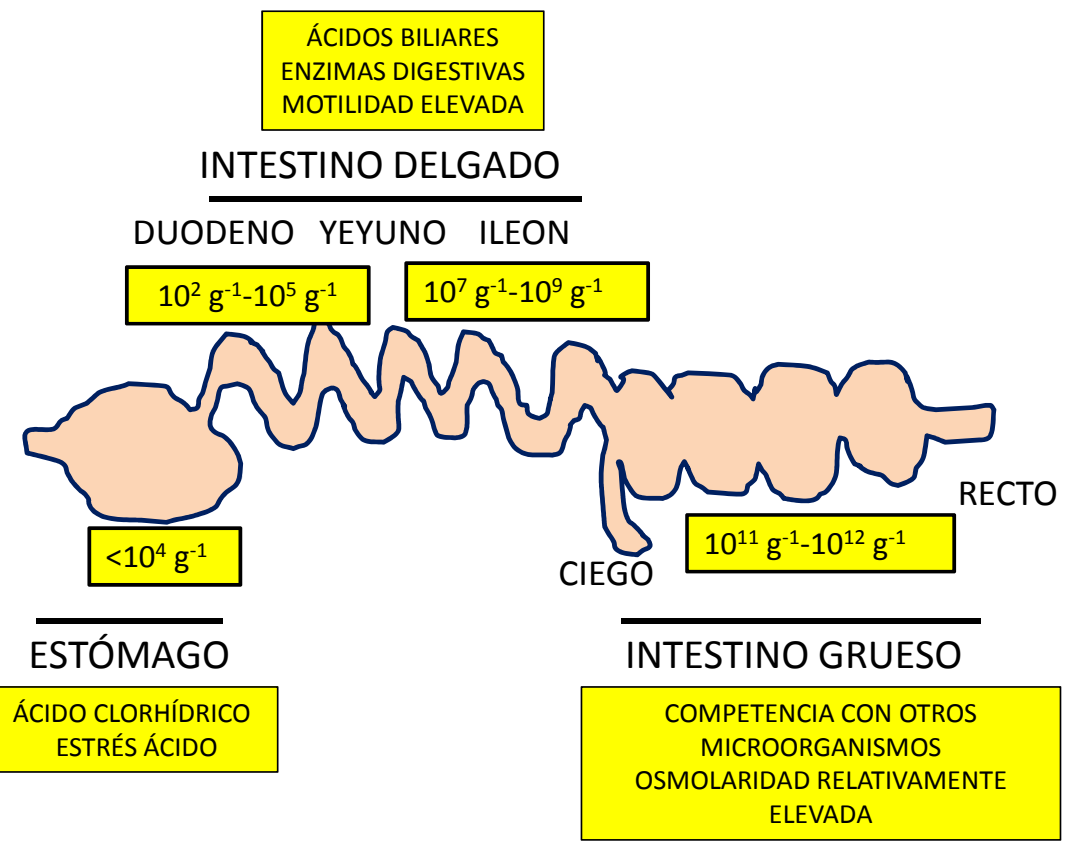

Figura 2. Carga microbiana en el tracto gastrointestinal y sus principales factores condicionantes. Adaptado de The extracellular biology of the lactobacilli (Kleerebezem, et al., 2010).

\subsection{Estómago:}

La mucosa gástrica favorece la digestión mediante la secreción de ácido clorhídrico y enzimas digestivas. El ácido clorhídrico estomacal hace que el $\mathrm{pH}$ alcance niveles muy bajos, cercanos a 1. Muy pocos microorganismos sobreviven a estas duras condiciones por lo que constituye una de las defensas más eficaces frente a los patógenos potenciales. En el estómago hay menos de $10^{4}$ células microbianas por gramo de contenido estomacal. 


\section{INTRODUCCIÓN}

\subsection{Intestino delgado:}

La elevada motilidad del intestino delgado, con un tiempo de tránsito de 4 a 6 horas, dificulta la adhesión y el crecimiento microbiano. Además, se vierten al mismo las sales biliares y las enzimas digestivas y los microorganismos han de competir por los azúcares fácilmente absorbibles con el hospedador. La presencia del gen de la hidrolasa de las sales biliares es considerada un marcador de adaptación microbiano al tracto gastrointestinal, al suponérsele un papel en la tolerancia a la bilis.

El intestino delgado puede dividirse en 3 zonas que pese a ser estructuralmente similares son funcionalmente diferentes: duodeno, yeyuno e ileon.

El 90\% de la absorción de nutrientes tiene lugar en el primer metro de intestino delgado. En el duodeno la carga microbiana es similar a la estomacal, pero va aumentando al pasar al yeyuno $\left(10^{3}\right.$ $10^{5}$ microorganismos $\left.\mathrm{g}^{-1}\right)$ e ileon $\left(10^{8}\right.$ microorganismos $\left.\mathrm{g}^{-1}\right)$.

\subsection{Intestino grueso:}

Al atravesar la válvula ileocecal, en el intestino grueso, encontramos microorganismos en gran número $\left(10^{11}-10^{12} \mathrm{~g}^{-1}\right)$. La motilidad más baja y el tiempo de residencia de más de 50 horas permiten una intensa interacción luminal-mucosal. El epitelio tiene una superficie plana con invaginaciones que forman criptas. El pH es neutro o ligeramente alcalino frente al $\mathrm{pH}$ ácido del estómago y porciones iniciales del intestino delgado y los microorganismos disponen de nutrientes: carbohidratos complejos de la dieta que no han podido digerirse, fibra, restos desprendidos de la mucosidad intestinal, células muertas procedentes de la renovación del epitelio y compuestos obtenidos a partir de las actividades metabólicas de otros miembros de la microbiota.

El principal escollo con el que se encuentran en el colon es la competencia con otros microorganismos y una osmolaridad relativamente elevada. También son destacables los diversos niveles de oxígeno, mientras que el lumen es principalmente anóxico, a nivel de la mucosa existen gradientes muy bruscos de oxígeno. 


\section{INTRODUCCIÓN}

\section{LA BARRERA MUCOSA DEL INTESTINO:}

La barrera mucosa es una estructura fisicoquímica compleja y estratificada que separa los tejidos del contenido luminal. Sus diversas capas son: mucus, epitelio, lamina propia y muscularis mucosae.

\subsection{Capa de mucus:}

La luz del tubo está en contacto con una capa de mucus constituida por glicolípidos y glicoproteínas grandes y altamente glicosiladas Ilamadas mucinas. La glicosilación alcanza el $80 \%$ del peso. En humanos existen 18 tipos de mucinas, siendo MUC2 la predominante tanto en el intestino delgado como en el grueso. Los grupos glicano de las mucinas les confieren resistencia proteolítica e hidrofilicidad, mientras que los puentes disulfuro intra en intermoleculares, gracias a sus abundantes residuos de cisteína, contribuyen a la estructura de la capa de mucus. Su carácter hidrofóbico aumenta al desplazarnos hacia regiones más distales debido a la secreción de lípidos surfactantes por las células epiteliales, lo que impide que toxinas hidrosolubles lleguen al epitelio.

El mucus actúa como una separación física entre lumen y epitelio y sirve de marco para el desarrollo de interacciones bacteriabacteria y bacteria-hospedador además de ser un lubricante para la motilidad intestinal. El mucus es también un importante mecanismo de defensa al proteger a la mucosa de daños y facilitar la reparación de lesiones. A su vez, es la primera barrera que se encuentran las bacterias intestinales.

Los patógenos deben atravesarla para alcanzar el epitelio durante la infección bien reduciendo los puentes disulfuro o mediante actividades proteasa o glicosidasa. En zonas inflamadas la capa de mucus es más delgada lo que favorece la adhesión e infiltración. 
Existe un equilibrio entre su síntesis por las células caliciformes y su degradación tanto por proteasas (de origen humano o bacteriano) como debida a la erosión causada por el tránsito gastrointestinal.

El grosor del mucus aumenta a medida que nos desplazamos de las zonas proximales a las distales del tracto. Comprende dos subcapas, una en contacto con la luz, más gruesa e hidrosoluble y otra en forma de gel insoluble, fuertemente adherida a los carbohidratos de superficie de las células epiteliales, de grosor menor y más constante, libre de microorganismos en los individuos sanos.

Como se verá más adelante, los microorganismos considerados probióticos podrían actuar a nivel de esta capa de mucus, promoviendo la secreción de mucus como un mecanismo de mejora de la función barrera y exclusión de patógenos (Ohland \& Macnaughton, 2010).

\subsection{Epitelio intestinal:}

La preservación de la homeostasis en la mucosa intestinal va en interés de la microbiota residente, pues le proporciona un hábitat conveniente. No debería sorprendernos por tanto el que varios miembros de la microbiota residente contribuyan a la integridad de la barrera a través del mantenimiento de las uniones entre células epiteliales y promoviendo la reparación del epitelio tras sufrir un daño.

Como se desarrollará más adelante, la microbiota del intestino proporciona al hospedador una barrera física frente a patógenos invasores por exclusión competitiva: ocupando sitios de unión, consumiendo fuentes de nutrientes, produciendo sustancias antimicrobianas o estimulando a las células del hospedador para que produzcan compuestos antimicrobianos. 


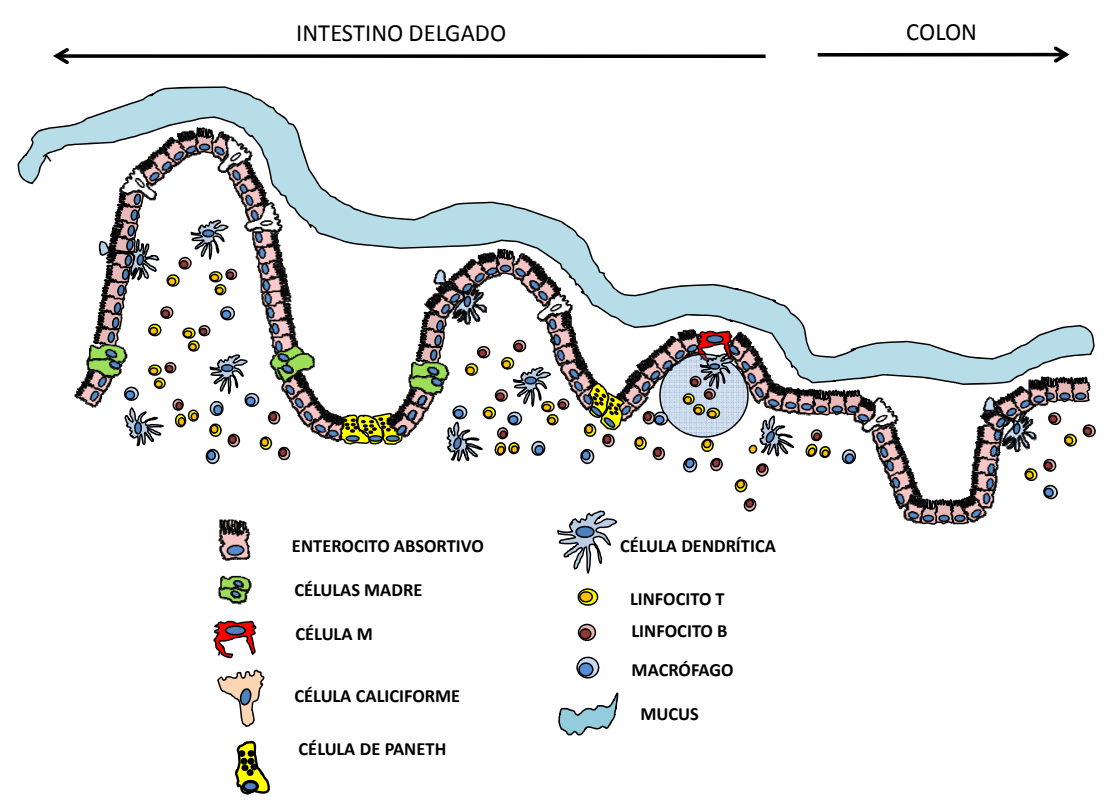

Figura 3. Representación esquemática de la superficie intestinal y sus diversos tipos celulares. El epitelio del intestino delgado se caracteriza por su distribución en vellosidades y criptas, mientras que el epitelio del colon es plano con hendiduras o criptas.

Está inducción parece requerir un contacto íntimo con el epitelio, pues los niveles de inducción de péptidos antimicrobianos son mucho más altos en ratones mutantes que carecen de inmunoglobulina A ( $\lg A)$ secretada $(\operatorname{sg} A)$ que secuestre las bacterias presentes en el lumen, respecto a los niveles inducidos en ratones silvestres (Sekirov, et al., 2010).

Bajo la capa de mucus se localiza el epitelio formado por diversos tipos celulares especializados. En el intestino delgado el epitelio alterna proyecciones en forma de dedo llamadas vellosidades, con criptas, mientras que en el intestino grueso el epitelio es plano con invaginaciones o criptas.

El epitelio está en renovación constante durante toda la vida a partir de células madre localizadas en las criptas a media altura. Cada 24 a 96 horas se produce una renovación completa del epitelio intestinal. 
Las células absortivas y las caliciformes (secretoras de mucus) migran hacia la parte superior de las vellosidades, mientras que las enteroendocrinas (que participan en la regulación de la función intestinal), las células de Paneth (que secretan sustancias antimicrobianas) y las células $M$ (que participan en la presentación de antígenos), migran hacia la base de las mismas (Figura 3).

La vellosidad permite un importante incremento de la superficie y sus principales funciones son la absorción de nutrientes y la secreción de mucus. Mientras que las criptas se especializan en renovación celular y secreciones endo, para y exocrinas. Los enterocitos absortivos llevan a cabo un transporte transcelular que requiere un espacio intercelular sellado, gradientes iónicos a través del epitelio para el transporte acoplado y una distribución polarizada de las proteínas de membrana.

La integridad estructural del epitelio tiene una importancia capital y en ella influyen los complejos de unión localizados lateralmente como las uniones estrechas (tight junctions), las uniones adherentes y los desmosomas, así como mecanismos de contracción del citoesqueleto de actomiosina.

Las uniones estrechas realizan una doble función: son un portal entre las células que limita el paso de moléculas cargadas o no y actúan como una barrera que evita que se mezclen por difusión los componentes de las porciones apical y basolateral de membrana.

La barrera constituida por el epitelio, responsable de separar el contenido luminal de tejidos subyacentes, se ve afectada en diversas enfermedades como las enfermedades inflamatorias (enfermedad de Chron y colitis ulcerosa), la enfermedad celiaca y enfermedades infecciosas.

\subsection{Tejido conectivo (membrana basal y lamina propria):}

Bajo las células epiteliales y rodeándolas encontramos tejido conectivo laxo. Junto con el epitelio constituye la mucosa, contiene capilares y presenta una gran concentración de células del sistema inmunitario e inmunoglobulinas. La matriz extracelular era considerada inicialmente tan solo como una sustancia amorfa que servía de base al epitelio. 


\section{INTRODUCCIÓN}

Actualmente se sabe que es un gel específico de tejido, altamente organizado y que regula diversos aspectos de la biología celular. Se trata de una red compleja e intrincada, cuyas moléculas constituyentes están organizadas de forma precisa. Esta red molecular determina la histoarquitectura de los tejidos y proporciona a las células información y un andamiaje. La mayoría de las moléculas que constituyen su estructura son quiméricas y presentan dominios comunes. Está compuesta por diversos tipos de colágeno, glicoproteínas diferentes al colágeno y proteoglicanos (Aumailley \& Gayraud, 1998). Las integrinas de superficie de las células epiteliales actúan como receptores de los componentes de la matriz, pudiendo iniciar importantes vías de señalización intracelular (Basson, 2003).

La matriz extracelular puede dividirse en membrana basal y lamina propia. El epitelio descansa sobre la membrana basal, una lámina relativamente bidimensional compuesta principalmente por diversas isoformas de colágeno IV y laminina, así como proteoglicanos de heparán sulfato. Además se encuentra una variedad de moléculas en diversa proporción, entre ellas fibronectina, entactina, tenascina, osteonectina, osteopontina $y$ decorina.

La membrana basal varía sustancialmente de las criptas a la punta de las vellosidades en la mucosa del intestino delgado. Variaciones en la proporción relativa de sus componentes se han descrito también en diversas enfermedades (Basson, 2003).

La lámina propia se localiza bajo de la membrana basal, es rica en colágeno de tipo I y de tipo III, así como en fibronectina y diversos proteoglicanos. La célula epitelial no está en contacto con la lamina propia salvo en casos de heridas, inflamación o invasión por patógenos. La matriz puede quedar expuesta en el caso de quedar dañado el epitelio por un trauma o un proceso de infección, pero parte de sus moléculas son liberadas de forma normal al mucus suprayacente. Por lo que la capacidad de ciertos lactobacilos de unirse a componentes de la matriz podría ser beneficiosa en caso de competir por los sitios de unión con patógenos, evitando de esta forma la colonización e infección. 


\section{INTRODUCCIÓN}

\subsubsection{Colágeno de tipo IV:}

Todos los miembros de la superfamilia de los colágenos son proteínas modulares compuestas por tres cadenas polipeptídicas con al menos una región en triple hélice y unos telopéptidos terminales no helicoidales. La contribución a la molécula de las regiones helicoidales o no varía en función del tipo de colágeno (Hulmes, 2002). La asociación de las tres cadenas viene determinada por el propéptido C-terminal. El colágeno de tipo IV no es un colágeno de tipo fibrilar y, al contrario que la mayoría, solo forma una malla plana.

Su cabeza globular se asocia con las de otras moléculas y su cola se asocia con los segmentos de cola de otras 3 moléculas de colágeno de tipo IV constituyendo una unidad de la estructura de la malla en forma de $X$ a la que se une la laminina (Basson, 2003).

\subsubsection{Laminina:}

Las lamininas son una familia de proteínas heterotriméricas compuestas por cadenas $\alpha$ (cadenas de brazos largos), $\beta, y\rangle$ (cadenas de brazos cortos). La expresión es función del tejido y del estado del desarrollo, reflejando su diversidad funcional (Simon-Assmann, et al., 1998).

\subsubsection{Fibronectina:}

Se trata de una glicoproteína de alto peso molecular que se une a integrinas de la superficie celular y a componentes de la matriz extracelular como el colágeno, la fibrina y los proteoglicanos de heparán sulfato. Es un dímero compuesto por dos monómeros aproximadamente idénticos unidos por un par de puentes disulfuro.

La hay soluble como uno de los componentes principales del plasma, producida por los hepatocitos, y la hay insoluble en la matriz extracelular, habiendo sido producida principalmente por los fibroblastos.

Es importante para la adhesión, crecimiento, migración y diferenciación celular así como en los procesos de cierre de heridas y desarrollo embrionario (Lucena, et al., 2007). 


\section{INTRODUCCIÓN}

\subsubsection{Fibrinógeno:}

Es una glicoproteína soluble del plasma de síntesis hepática implicada en la hemostasis al pasar a gel insoluble (fibrina). Se han identificado múltiples sitios extra-hepáticos de síntesis de fibrinógeno como las células epiteliales del intestino $y$ se ha constatado su presencia en la matriz extracelular donde colocaliza con la laminina y la fibronectina. Participa en la regulación de procesos celulares implicados en reparación de heridas (Pereira \& Simpson-Haidaris, 2001).

\subsubsection{Colágenos de tipo fibrilar:}

Las proteínas estructurales de colágeno son las principales responsables de la integridad estructural de los vertebrados y muchos otros organismos multicelulares. Tras su síntesis son secretadas a la matriz extracelular como precursores solubles, los procolágenos. Estos sufren un procesado proteolítico de los propéptidos en $\mathrm{N}$ y C-terminal por proteinasas específicas y el colágeno maduro se ensambla espontáneamente formando fibrillas. Solo unos 5 tipos de colágeno (I, II, III, V y XI) son fibrilares de entre los más de 20 tipos conocidos en humanos.

El colágeno de tipo I y el de tipo III son abundantes en la lámina propia. El de tipo III está compuesto por tres cadenas idénticas de tipo $\alpha 1(I I I)$, mientras que el de tipo I está compuesto por 2 cadenas $\alpha 1(\mathrm{I})$ y una cadena $\alpha 2(\mathrm{I})$. En ambos casos las regiones que no forman triple hélice son cortas (Hulmes, 2002).

\subsection{Tejido linfoide asociado a la mucosa gastrointestinal:}

El GALT o tejido linfoide asociado a mucosas del tracto gastrointestinal (Gut Associated Lymphoid Tissue), convierte a éste en el mayor órgano del sistema inmune del cuerpo, al contener la mayor fuente de células inmunocompetentes del mismo (Ramiro-Puig, et al., 2008). 
Contiene más de $10^{6}$ linfocitos por gramo de tejido y aproximadamente el $60 \%$ del total de inmunoglobulinas producidas diariamente (varios gramos), son secretadas al tracto gastrointestinal (Salminen, et al., 1998).

A través de la inmunidad innata y adquirida el organismo ha de tolerar los antígenos de la dieta y la microbiota endógena residente, mientras que debe reconocer y rechazar los microorganismos enteropatógenos. Esto es probablemente resultado de una evolución bajo presión selectiva. Bajo condiciones normales el GALT ha de mantenerse hipo-responsivo y ser capaz de respuestas rápidas ante los patógenos. El equilibrio entre la tolerancia y la activación está mantenido por una compleja red en la que participan células inmunes y epiteliales. La rotura del mismo conduce a la aparición de enfermedades inflamatorias intestinales.

Los agregados linfoides se encuentran frecuentemente en el intestino delgado, pueden estar determinados por el desarrollo o formarse por neogénesis bajo estimulación, contienen centros germinales y tienen un epitelio asociado con células $\mathrm{M}$ (micropliegue) presentadoras de antígeno. El tipo mejor caracterizado son los parches de Peyer (Figura 4).Los linfocitos se dividen entre los de la lámina propia y los intraepiteliales. Estos últimos disminuyen en número al desplazarnos del intestino delgado al colon donde la carga bacteriana es mayor.

En la lámina propia hay un enorme número de células $B$, la mayoría se acaban diferenciando en células plasmáticas secretoras de IgA. El $80 \%$ de las células plasmáticas del cuerpo se localizan en la mucosa intestinal y el isotipo de Ig producido en mayor cantidad es el A. Dicha IgA, llega al lumen por transporte transepitelial donde se conoce como IgA secretoria y genera una protección inmune no inflamatoria. Puede atrapar bacterias y antígenos de la dieta en el mucus, disminuyendo los epitopos proinflamatorios en las bacterias comensales, bloqueando la unión bacteriana a la superficie epitelial, mediando la neutralización intraepitelial de patógenos y facilitando la presentación de antígenos. Al recubrir genera una envuelta hidrofílica que es repelida por el glicocalix del epitelio. 


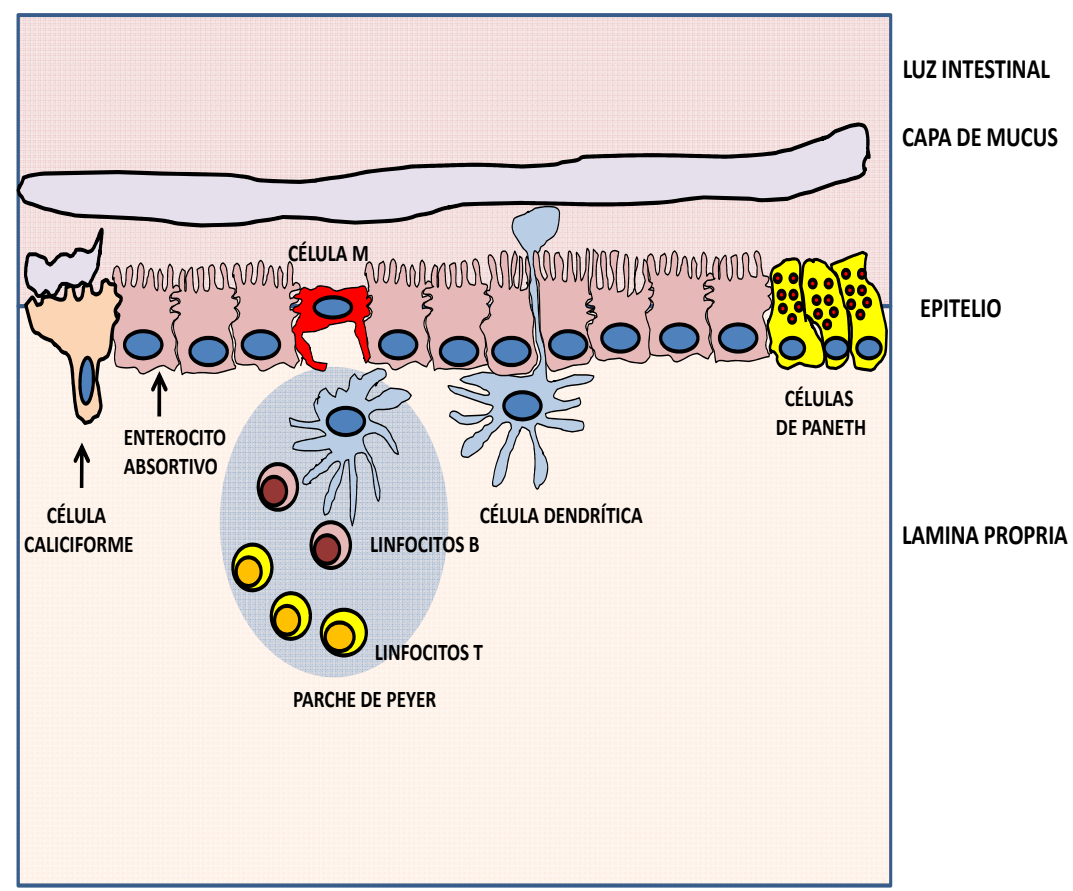

Figura 4. Esquema de las capas de la mucosa intestinal.

Las células dendríticas proyectan prolongaciones como si de periscopios se tratara, entre los enterocitos, para sondear antígenos y bacterias del lumen, aunque el sitio principal de presentación de antígenos son los parches de Peyer. El riego sanguíneo conecta el sitio de estimulación con los sitios periféricos de actuación. Los linfocitos estimulados en los parches de Peyer migran a través del conducto torácico o conducto linfático izquierdo a la circulación distribuyéndose a sitios tanto intra como extraintestinales donde se produce IgA que es transportada a la superficie mucosa. Una de las técnicas más comúnmente empleadas que demuestran la contribución del intestino a la inmunidad mucosal es la inmunización o vacunación oral (Kang \& Kudsk, 2007). 


\section{INTRODUCCIÓN}

\section{BACTERIAS LÁCTICAS:}

Las bacterias lácticas son un grupo de microorganismos Gram-positivos, no esporulantes, quimio-organotrofos, que usan la fermentación de carbohidratos como fuente de energía. El producto final mayoritario de la fermentación de carbohidratos es el ácido láctico, lo que les confiere su nombre, aunque otros ácidos orgánicos como el acetato son producidos, además de etanol y $\mathrm{CO}_{2}$, en determinadas condiciones (heterofermentación).

Filogenéticamente las bacterias lácticas pertenecen a los Firmicutes, y a la subdivisión Clostridium-Bacillus de las Eubacterias Gram-positivas y son por tanto organismo con un contenido en $\mathrm{G}+\mathrm{C}$ en su DNA inferior al $50 \%$.

Aunque esta descripción incluye cocos (Lactococcus, Leuconostoc, Oenococcus, Pediococcus, Streptococcus, Enterococcus, etc), los bacilos son los más importantes, con el género Lactobacillus como el mayoritario, el cual comprende 148 especies reconocidas.

Las bacterias lácticas se caracterizan por desarrollarse en hábitats nutricionalmente complejos y muchas de ellas participan en la elaboración de multitud de alimentos fermentados. Así, dentro del género Lactobacillus se encuentran especies exclusivas de productos de lechería (Lactobacillus delbrueckii subsp. bulgaricus, Lactobacillus helveticus), especies aisladas frecuentemente de productos cárnicos (Lactobacillus curvatus, Lactobacillus sakei), otras frecuentemente encontradas en el tracto gastrointestinal de vertebrados (Lactobacillus acidophilus, Lactobacillus gasseri) y especies con una gran adaptabilidad a diversos hábitats (Lactobacillus plantarum, Lactobacillus casei).

Los genomas de bacterias lácticas completados y aquellos cuya secuenciación está en curso han permitido, a partir de la anotación y reconstrucción metabólica, determinar el considerable grado de auxotrofía para aminoácidos y otros bloques de construcción celular. Se considera que esta característica es debida a la complejidad y riqueza nutricional de los nichos donde estas bacterias se desarrollan. 


\section{INTRODUCCIÓN}

Así, esto se compensa codificando en sus genomas gran variedad de funciones de importación de nutrientes ambientales a su metabolismo.

\subsection{Lactobacillus casei:}

L. casei es el microorganismo objeto del presente estudio. Es una bacteria láctica versátil aislada de variedad de hábitats ambientales como leche cruda o fermentada (sobre todo queso), carne, materia vegetal y los tractos reproductivos y gastrointestinales de animales y humanos.

Esta especie presenta aplicaciones diversas en la industria alimentaria: como cultivo iniciador productor de ácido que contribuye a la conservación del alimento, como cultivo que favorece el desarrollo de las características organolépticas deseadas o como cultivo que acelera la maduración. Algunas cepas son empleadas biotecnológicamente para producir ácido láctico por fermentación de diversos substratos naturales. La aplicación en alimentos y biotecnológica ha llevado a que esta especie haya sido objeto de numerosos estudios fisiológicos y genéticos. A su vez, es una especie que comprende cepas que son frecuentemente incluidas en productos para el consumo humano como probióticos (ej.: Yakult ${ }^{\circledR} \mathrm{o}$ Actimel $\left.^{\circledR}\right)$.

En estudios realizados en modelos animales, concretamente ratón, se ha constatado la expresión de genes en diversos nichos del tracto gastrointestinal y el que sus células son metabólicamente activas e inician la síntesis proteica de novo para adaptarse a los mismos (Oozeer, et al., 2005).

La definición taxonómica de $L$. casei ha estado sujeta a multitud de polémicas. Estudios taxonómicos han demostrado que la cepa tipo (L. casei ATCC393) está filogenéticamente alejada del resto de aislados clasificados dentro de la misma especie que, por otro lado, forman un taxón homogéneo. 
Esto llevó a proponer otra especie para este grupo de aislados: Lactobacillus paracasei (Collins, et al., 1989) u otra cepa tipo diferente para L. casei (L. casei ATCC334) y el rechazo de la especie $L$. paracasei (Dicks, et al., 1996). Recientemente, la Comisión Judicial del Comité Internacional de Sistemática Bacteriana desestimó la designación de una nueva cepa tipo para $L$. casei y aceptó la creación de la nueva especie L. paracasei (cepa tipo L. paracasei ATCC25302; Judicial Commission of the International Committee on Systematics of Bacteria, 2008).

Esta situación ha llevado a multitud de confusiones y en la actualidad, aunque la especie $L$. paracasei está reconocida, se sigue utilizando el nombre de L. casei como sinónimo de L. paracasei en multitud de trabajos y cepas. La antigua subespecie $L$. casei subsp. rhamnosus, posee en la actualidad el rango de especie (Lactobacillus rhamnosus) y también presenta un hábitat intestinal, con varias cepas utilizadas comúnmente como probióticos.

Existen en la actualidad varios proyectos de secuenciación de cepas de L. casei completados o en curso (ej.: cepas ATCC334, BL23, Zhang, etc.). Esto nos va a permitir realizar estudios comparativos que arrojen luz acerca de la evolución, la adaptación a diversos ambientes y la consiguiente diversidad metabólica (Cai, et al., 2009, Maze, et al., 2010).

\section{PROBIÓTICOS, PREBIÓTICOS Y SIMBIÓTICOS:}

Los probióticos son microorganismos viables y no patogénicos que administrados en cantidad suficiente pueden conferir un beneficio al hospedador más allá del puramente nutricional (Food and Agriculture Organization of the United Nations. \& World Health Organization., 2006).

Mucho antes de establecerse la definición de probióticos e incluso de descubrir la existencia de los microorganismos, ya se utilizaban productos lácteos fermentados para tratar diversas dolencias gastrointestinales como quedó registrado por el historiador romano Plinio en el 76 A.C. 


\section{INTRODUCCIÓN}

Pero no fue hasta los últimos años del siglo XIX que las bases científicas del concepto de probiótico fueron establecidas por Elie Metcnikoff. Fue el introductor de la bacterioterapia oral; propuso "sembrar" el tracto gastrointestinal con bacterias ácido lácticas inofensivas que suprimieran el crecimiento de bacterias proteolíticas nocivas, reduciendo la putrefacción en el intestino y prolongando la esperanza de vida del individuo. Por tanto el efecto propuesto más antiguo de los probióticos es actuar sobre el equilibrio de la microbiota intestinal.

En los primeros años del siglo XX, Tissier fue el primero en aislar y describir bifidobacterias de heces de lactantes. Estas bacterias pasaron a asociarse con un tracto gastrointestinal sano dada su predominancia en el intestino de los niños alimentados por lactancia materna en contraste con aquellos alimentados con fórmula, los cuales sufrían una mayor incidencia de diarrea (Kleerebezem \& Vaughan, 2009).

Poco después de establecer estos postulados empezaron a dispensarse como medicamentos sin receta y suplementos diversas cepas de bacterias lácticas y bifidobacterias para el tratamiento de la diarrea y a incluirse también en productos alimentarios para promover la salud intestinal y prevenir la enfermedad (Jankovic, et al., 2010).

Su administración es preferiblemente oral en forma de productos frescos fermentados o suplementos microbianos secos y su sitio de acción preferente el tracto gastrointestinal. No obstante, los microorganismos probióticos pueden desarrollarse en otros tipos de mucosas, pudiéndose emplear probióticos con el objeto de mejorar la salud a nivel de mucosa oral o vaginal.

Los esfuerzos para demostrar científicamente los efectos beneficiosos de los probióticos empezaron principalmente en la década de los años 80 del pasado siglo XX, acelerándose rápidamente la investigación a partir del año 2000. Hay una acumulación de datos que apoyan la existencia de efectos beneficiosos que varían en función de la cepa empleada, la dosis, así como el modo y la frecuencia de aplicación (Sherman, et al., 2009). 
Entre los diferentes efectos beneficiosos cabe destacar el tratamiento de la intolerancia a la lactosa, la prevención y tratamiento de diarreas, el efecto anticolesterolémico y el mantenimiento de la homeostasis intestinal mediante inmunoregulación y mantenimiento de la barrera intestinal.

La mayoría de bacterias probióticas fueron originalmente aisladas de humanos sanos y son así consideradas aptas para el consumo, de forma que lo único que las distingue de las comensales es la capacidad de ejercer efectos beneficiosos al ser consumidas.

Entre los microrganismos considerados probióticos se encuentran cepas de los géneros Bifidobacterium, Lactobacillus, Streptococcus, Enterococcus, Escherichia, Bacillus así como levaduras del género Saccharomyces.

La aplicación de microorganismos probióticos requiere una evaluación exhaustiva de su seguridad existiendo múltiples directrices al respecto como la QPS (Qualified Presumption of Safety) de la EFSA (European Food Safety Authority) o la GRAS (Generally Recognized as Safe) de la FDA (American Food and Drug Administration).

Los prebióticos o alimentos colónicos son ingredientes alimentarios resistentes a la acidez gástrica y a las enzimas digestivas (pancreáticas y del borde en cepillo de los enterocitos), no absorbibles, fermentables y capaces de estimular de forma selectiva el crecimiento o actividad metabólica de grupos concretos de bacterias entéricas beneficiosas, favoreciendo así al hospedador. Actualmente están bien establecidos como prebióticos la inulina, los fructo-oligosacáridos, los galacto-oligosacáridos y la lactulosa. 


\section{INTRODUCCIÓN}

Las propiedades prebióticas de los carbohidratos se ven influidas por diversos factores:

- Los monosacáridos constituyentes: los prebióticos establecidos están predominantemente compuestos por glucosa, galactosa, xilosa y fructosa.

- El tipo de enlace glicosídico: esencial para determinar la fermentación selectiva y su digestibilidad en el intestino delgado.

- El peso molecular: los oligosacáridos son prebióticos en su metabolismo mientras que los polisacáridos generalmente no lo son.

La combinación de pro y prebióticos da como resultado los simbióticos. Dicha combinación busca promover la supervivencia de los microorganismos ingeridos y favorecer la colonización del tracto gastrointestinal (Gibson \& Roberfroid, 1995, Bosscher, et al., 2009).

\section{CONTRIBUCIÓN DE LOS PROBIÓTICOS A LA FUNCIÓN BARRERA INTESTINAL:}

Los datos disponibles sobre la funcionalidad de probióticos a nivel intestinal proceden en su mayoría de estudios in vitro con monocapas de células epiteliales, pero también se dispone de datos obtenidos con modelos animales y cada vez más en estudios clínicos. Los estudios pueden emplear una cepa probiótica en concreto, mezclas de diferentes cepas, lisados celulares o el medio de crecimiento condicionado (Otte \& Podolsky, 2004).

La contribución de los probióticos a la función barrera del epitelio intestinal se basa en 3 tipos de efectos: sobre el epitelio, sobre el GALT y sobre la microbiota (Ohland \& Macnaughton, 2010) (Figura 5). 


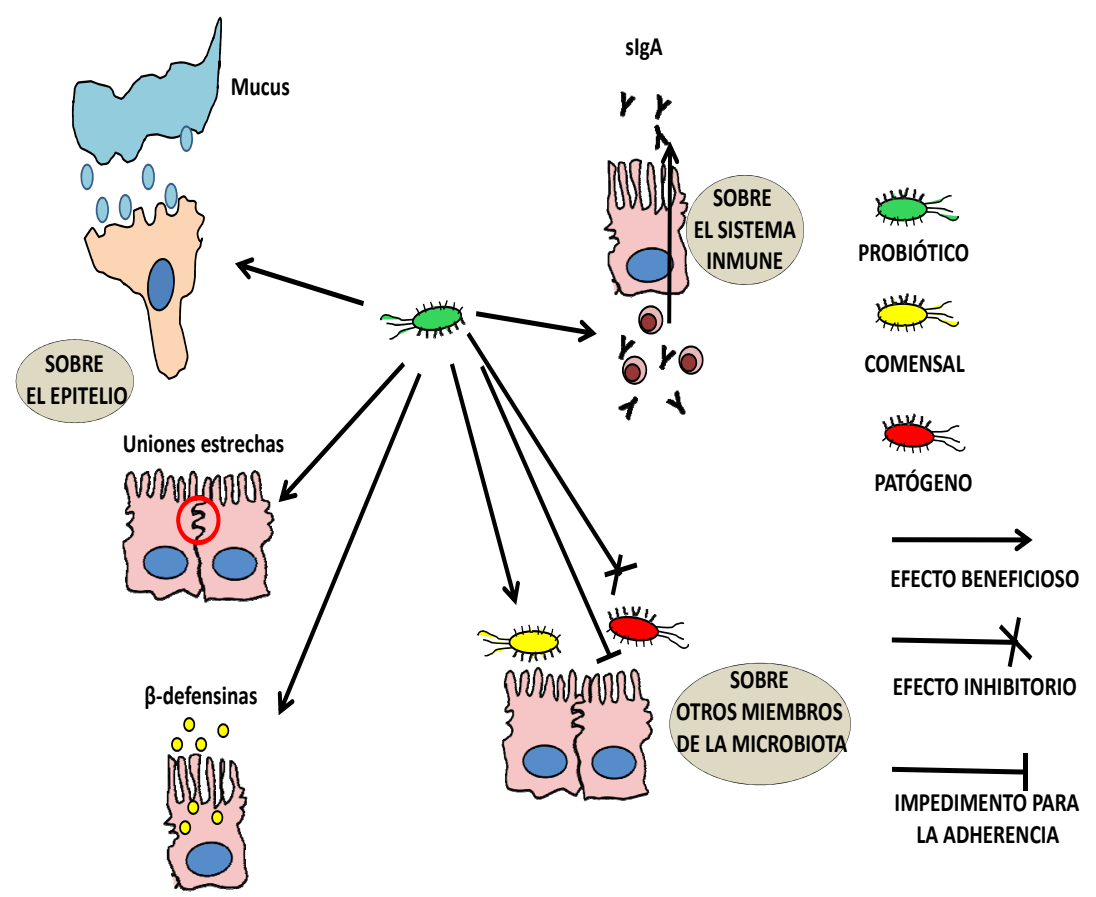

Figura 5. Contribución de los probióticos a la función barrera.

\subsection{Efectos sobre el epitelio:}

7.1.1 Incrementando la secreción de mucus por las células caliciformes:

Ya en el año 1999, Mack y colaboradores plantearon la posibilidad de que la capacidad de los probióticos de inhibir la unión de enteropatógenos al epitelio intestinal se debiera a que estimularan la secreción de mucinas. Observaron que la incubación de células epiteliales intestinales HT-29 con lactobacilos probióticos producía una disminución significativa de la adherencia de Escherichia coli enteropatógena y un aumento significativo de la expresión de MUC-2 y MUC-3 (Mack, et al., 1999). 


\section{INTRODUCCIÓN}

En un estudio posterior encontraron una correlación entre la capacidad de adhesión de la cepa de Lactobacillus empleada a la línea celular y la estimulación de la producción y secreción de mucus, pues las cepas menos adherentes no producían dicho incremento (Mack, et al., 2003).

Mattar y colaboradores observaron un efecto inhibitorio sobre la translocación epitelial en cultivos celulares de la línea de enterocitos Caco-2 y en un modelo neonatal de conejo, tanto al añadir mucina como al añadir L. rhamnosus GG. Lo que les llevo a plantear la hipótesis de que la adición de la cepa estimulaba la producción de mucina. Para poner a prueba la hipótesis usaron monocapas de células Caco-2. Las cuales en presencia de la cepa probiótica L. rhamnosus GG mostraron aumentos significativos en el mRNA de MUC-2 y en la cantidad de esta proteína (Mattar, et al., 2002).

Caballero-Franco y colaboradores ensayaron el efecto de la fórmula probiótica VSL\#3 (una mezcla liofilizada de 8 microorganismos Gram-positivos: 4 especies de lactobacilos, 3 de bifidobacterias y una de streptococos) en ratas Wistar, donde observaron un incremento del contenido luminal de mucus de un $60 \%$ y un aumento de la expresión de MUC-2. Por su parte al usar la línea de células epiteliales colónicas LS 174T la incubación con la fórmula no produjo un aumento de la secreción de mucus, pero sí la adición del medio condicionado que contiene productos secretados por las bacterias. Las especies de lactobacilos fueron las que produjeron un efecto mayor in vitro (Caballero-Franco, et al., 2007).

\subsubsection{Produciendo ácidos grasos de cadena corta:}

Los probióticos, en el ciego y colon proximal principalmente, pueden fermentar carbohidratos de la dieta que no han sido digeridos y absorbidos en el intestino delgado generando ácidos grasos de cadena corta. Estos metabolitos son fácilmente absorbibles, de forma que solo el $5-10 \%$ se elimina con las heces. Su efecto sobre receptores del epitelio intestinal como GPT41 y GPR43 promueve el peristaltismo intestinal (Ohara, et al., 2009). 
El butirato es la principal fuente de energía de los colonocitos y está implicado en el control de la maquinaria que regula la proliferación celular, la diferenciación y la apoptosis (Hijova \& Chmelarova, 2007). Puede participar en la prevención del cáncer colorectal mediante la activación de enzimas metabolizadoras de drogas, como la glutation-S-transferasa, capaz de detoxificar carcinógenos endógenos o exógenos, o actuar sobre células ya transformadas como inhibidor de la histona desacetilasa, promoviendo la detención del ciclo celular y la apoptosis (Scharlau, et al., 2009).

En un estudio llevado a cabo por Le Leu y colaboradores con ratas Sprague-Dawley, al administrar la combinación simbiótica de Bifidobacterium lactis y almidón resistente aumentó la concentración de ácidos grasos de cadena corta en el recto con respecto al control $(p=0.03)$ y se redujo un $50 \% \quad(p<0.01)$ la inducción de cáncer colorectal por azoximetano (Le Leu, et al., 2010).

7.1.3 Incrementando la secreción de péptidos antimicrobianos ( $\beta$ defensinas) por parte de los enterocitos:

Schlee y colaboradores empleando la cepa probiótica Escherichia coli Nissle 1917 observaron una inducción de la producción de la beta defensina humana 2 (hBD-2). La inducción era mayor al usar el sobrenadante del medio de cultivo que al usar las propias bacterias, por lo que la molécula responsable de este efecto debía tratarse de un factor soluble o desprendido de la superficie. La construcción de mutantes deletéreos y posteriores complementaciones demostraron que el principal estimulador de $E$. coli Nissle 1917 es la flagelina (Schlee, et al., 2007).

En un estudio posterior ensayaron el efecto de diversas cepas de Lactobacillus y de la mezcla probiótica VSL\#3 sobre la producción de hBD-2 en células Caco-2. Se observó un aumento dependiente del tiempo y la dosis en la expresión del gen y una secreción al medio de cultivo en la que participa la inducción de vías proinflamatorias (Schlee, et al., 2008). 


\section{INTRODUCCIÓN}

7.1.4 Favoreciendo la estabilidad de las uniones estrechas disminuyendo la permeabilidad epitelial a patógenos o sus productos:

Karczewski y colaboradores observaron un aumento de proteínas del sello paracelular en el epitelio de individuos sanos a los que se les había suministrado L. plantarum WCFS1 en el duodeno mediante catéter respecto a los que habían recibido placebo. Efectos similares y de importancia en la integridad del epitelio se encontraron en cultivos celulares de células Caco-2 al añadirles dicha cepa. Estos efectos estaban mediados por la interacción con el receptor TLR-2 de las células eucariotas (Karczewski, et al., 2010).

Anderson y colaboradores estudiaron el efecto de diversas cepas probióticas en la potenciación de la función barrera sirviéndose de la medida de la resistencia transepitelial en células Caco- 2 . Seleccionaron la cepa L. plantarum DSM 2648 para sucesivos experimentos por ser la que mayor incremento de la resistencia transepitelial producía. Ya fuera mediante un cocultivo previo o simultaneo, esta cepa era capaz de disminuir el efecto negativo de $E$. coli enteropatógena 0127:H6 sobre la adhesión y sobre la resistencia transepitelial, potenciando por tanto el efecto barrera (Anderson, et al., 2010).

Mennigen y colaboradores se sirvieron de un modelo murino de colitis para estudiar el efecto de la mezcla probiótica VSL\#3 sobre la expresión de las proteínas de la unión estrecha y el ratio de apoptosis de las células epiteliales. El control tratado con placebo presentaba una disminución de la expresión de ocludina, las claudinas y zonula occludens- 1 , así como un aumento en el ratio de apoptosis y en la permeabilidad epitelial. Sin embargo el tratamiento con VSL\#3 prevenía estos cambios confirmando la protección de la barrera epitelial en casos de colitis aguda gracias al tratamiento probiótico (Mennigen, et al., 2009).

En un modelo de infección por Shigella dysenteriae en rata, en los controles se producía un daño en la integridad de la membrana de las células epiteliales y una disminución de la expresión de las proteínas de los complejos laterales de unión. 
Dicho daño se veía reducido significativamente al administrar previamente una mezcla de L. rhamnosus y L. acidophilus (Moorthy, et al., 2009).

La administración de la cepa probiótica E. coli Nissle 1917 se ha mostrado capaz de prevenir el daño sobre la integridad de la barrera producido en modelos murinos de colitis inducida. En los ratones a los que se les administró el probiótico se confirmó un aumento de la expresión de zonula occludens-1, así como una disminución de la pérdida de peso, el acortamiento del colon y la infiltración de leucocitos (Ukena, et al., 2007).

\subsubsection{Promoviendo la homeostasis intestinal a través de rutas de señalización específicas:}

L. rhamnosus GG es una bacteria empleada en varios productos por sus características probióticas y es una de las cepas de Lactobacillus más estudiadas en ensayos clínicos relativos a enfermedades inflamatorias del intestino.

Yan y colaboradores purificaron 2 proteínas secretadas por esta cepa, la p40 (40 KDa) y la p75 (75 KDa), que participan en la regulación de respuestas antiapoptóticas y proliferativas de las células epiteliales intestinales (Yan, et al., 2007).

Estos autores realizaron ensayos con células epiteliales intestinales en cultivo de colon humano o de ratón o bien con explantes de colon de ratón. Las proteínas purificadas fueron capaces de activar Akt, que promueve la supervivencia celular al inactivar vías proapoptóticas y estimula la proliferación mediante su efecto sobre reguladores del ciclo celular. Así mismo redujeron significativamente el daño celular generado al incubar las células epiteliales intestinales en presencia de TNF- $\alpha$. Se trata de las primeras proteínas bacterianas probióticas para las que se ha demostrado que promueven la homeostasis intestinal a través de rutas de señalización específicas.

En un trabajo posterior, Bäuerl y colaboradores estudiaron la cepa probiótica L. casei BL23 que presenta genes que codifican proteínas homólogas de las p40 y p75 de L. rhamnosus GG. 


\section{INTRODUCCIÓN}

Encontraron que dichas proteínas estaban tanto en superficie como secretadas al medio. Purificadas como fusiones GST eran capaces de hidrolizar muropéptidos, y en el caso de mutar el gen codificante de la p75 las células formaban cadenas de gran longitud, por lo que participarían en el metabolismo de la pared celular.

Las fusiones GST purificadas fueron capaces de unir mucina, colágeno y células epiteliales intestinales en cultivo. Además al igual que p40 de $L$. rhamnosus GG, ambas fusiones fueron capaces de estimular la fosforilación del receptor de EGF (Epidermal Growth Factor) en intestino de ratón ex vivo, lo que sugiere que muy probablemente estás proteínas se hayan implicadas en el efecto probiótico descrito para estas bacterias (Bauerl, et al., 2010).

\subsection{Efectos sobre el sistema inmune asociado a mucosas:}

\subsubsection{Incrementando el número de células productoras de inmunoglobulina $A$ en la lámina propia:}

En un modelo murino tras la administración de L. casei durante 7 días, el análisis de los parches de Peyer permitió determinar la existencia de una activación de las células implicadas en la inmunidad innata, entre ellas las células productoras de IgA, con un aumento de sus marcadores específicos TLR-2 y CD-206. No se generaron anticuerpos contra $L$. casei ni se apreciaron diferencias en el número de linfocitos T (Galdeano \& Perdigon, 2006).

La administración continuada, en otro estudio, de leche fermentada conteniendo bacterias probióticas a ratones $B A L B / c$ no produjo efectos secundarios y tuvo efectos inmunomoduladores sobre el mantenimiento de la homeostasis intestinal. El número de células productoras de IgA aumentó tanto en el intestino delgado como en el grueso. También se observó un incremento en diversas citoquinas reguladoras como IL-10, que previene la aparición de una respuesta inflamatoria (de Moreno de LeBlanc, et al., 2008). 
7.2.2 Promoviendo la secreción de la IgA al mucus luminal:

La cepa Bifido B de B. animalis subsp. lactis al ser suministrada a ratones gnotobióticos es capaz de colonizar y mantener unos niveles poblacionales altos. Los ratones colonizados por esta cepa muestran niveles más altos de slgA e IL-10 en relación a los controles y pueden conferir protección frente a Salmonella, lo que se refleja en una menor mortalidad (Martins, et al., 2010).

De igual manera, otros trabajos constataron un aumento en los niveles de slgA principalmente para Saccharomyces boulardii, seguida de E. coli EMO y B. animalis (Martins, et al., 2009).

La administración de leche fermentada con starters de yogur y la cepa probiótica L. casei DN-114001 a ratones mejora la microbiota intestinal incrementando la población de bifidobacterias y disminuyendo la de enterobacterias en el intestino grueso. Esto va acompañado de una estimulación de los macrófagos, las células dendríticas y las células IgAt, aumentando la forma secretada de IgA en los fluidos intestinales y mejorando la respuesta inmune (de Moreno de LeBlanc, et al., 2008).

El consumo por parte de niños sanos de un producto probiótico conteniendo Lactobacillus coryniformis CECT5711 y L. gasseri CECT5714 mejoró la salud de su flora intestinal y potenció sus defensas entre otras cosas aumentando la cantidad de slgA, tal y como mostraron los análisis de heces y saliva (Lara-Villoslada, et al., 2007).

\subsection{Efectos sobre otros miembros de la microbiota:}

\subsubsection{Compitiendo por sitios de unión con comensales o patógenos:}

Los probióticos podrían usar los mismos sitios de unión que los patógenos, compitiendo por la unión a la mucosa e impidiendo la invasión de la misma. La capacidad de inhibir la unión de patógenos o de desplazarlos es uno de los aspectos más importantes de la manipulación terapéutica de la microbiota intestinal mediante el uso de probióticos. 


\section{INTRODUCCIÓN}

Se requiere una evaluación caso por caso ya que se ha constatado que el efecto observado depende tanto de las cepas de microorganismos probióticos y patógenos empleadas como del sistema modelo utilizado en el estudio (proteínas inmovilizadas, líneas celulares, etc.).

L. rhamnosus GG y L. casei Shirota son capaces de competir y desplazar cepas patógenas intestinales de E. coli y Salmonella del mucus intestinal humano y células Caco-2, aunque este desplazamiento es relativamente lento (Lee, et al., 2003).

Collado y colaboradores señalaron también la necesidad de evaluar caso por caso a la hora de seleccionar cepas probióticas con el objetivo de prevenir o corregir desviaciones de la microbiota intestinal. En el estudio se sirvieron de un modelo in vitro de adhesión con mucus intestinal humano inmovilizado y experimentaron distintas combinaciones de cepas patógenas y de cepas probióticas comerciales. Todas las cepas fueron capaces de adherirse al mucus con valores de adhesión más o menos altos. La capacidad de inhibir la adhesión, de competir o de desplazar los patógenos ya adheridos fue dependiente de la combinación particular de cepas (Collado, et al., 2007).

La adhesión a células Caco-2 por L. plantarum 423 es capaz de prevenir la adhesión de Clostridium sporogenes y Enterococcus faecalis y también de desplazar estas bacterias por exclusión competitiva. Dicha capacidad se conserva en gran medida tras eliminar las proteínas de superficie, por lo que se deduce que existen componentes de superficie no proteicos implicados en la adhesión (Ramiah, et al., 2008).

Otros estudios, utilizando líneas celulares epiteliales T84 y de intestino embrionario 407 tratadas con diversas cepas de lactobacilos probióticos, han mostrado una disminución en la invasión por Campylobacter jejuni. Esta reducción de la invasión del patógeno se correlaciona con la capacidad adhesiva de las cepas de Lactobacillus, lo cual sitúa al proceso de adhesión como clave en el efecto probiótico de algunas cepas (Wine, et al., 2009). 
La capacidad de adhesión tanto de cepas probióticas comerciales de lactobacilos como de otras aisladas de heces de neonato suele ser dependiente de cepa y la capacidad de inhibir la unión de patógenos presenta una dependencia con la dosis de la cepa y en algunos casos es independiente de la viabilidad de la bacteria, encontrándose resultados similares con células vivas o inactivadas por calor (Ostad, et al., 2009).

\subsubsection{Compitiendo por la disponibilidad de sustrato:}

Impedir el acceso de determinados microorganismos a recursos nutritivos juega un papel importante en la defensa del hospedador. Es la base de una dieta prebiótica, la cual proporciona una ventaja selectiva a los microorganismos probióticos beneficiosos frente a los patógenos. Un mejor conocimiento de los nichos preferidos por los diferentes microorganismos en el intestino y sus necesidades nutricionales puede permitir el diseño de estrategias de intervención basadas en la nutrición (Schaible \& Kaufmann, 2005). Los oligosacáridos (OS) como fructo-OS, galacto-OS, lactosacarosa, lactulosa, malto-OS, oligosacáridos de habas de soja o soya-OS, glucoOS, xylo-OS, gentio-OS, polidextrosa e inulina son componentes mayoritarios de dietas prebióticas (Manning \& Gibson, 2004).

\subsubsection{Produciendo sustratos metabolizables por determinados} miembros de la microbiota beneficiosos para el hospedador:

El proceso fermentativo implica diferentes grupos funcionales de microorganismos unidos en una cadena trófica. El ácido láctico generado por la fermentación de oligosacáridos llevada a cabo por un grupo de microorganismos puede ser aprovechado como sustrato por otros utilizadores del mismo como las bacterias productoras de propionato, algunas productoras de butirato $y$ bacterias reductoras de sulfato (SRB, sulphate-reducing bacteria) (Chassard, et al., 2008). Esto evita la acumulación del mismo en el intestino de individuos sanos y permite que la reacción de obtención del ácido láctico pueda seguir llevándose a cabo al ser termodinámicamente favorable. 


\section{INTRODUCCIÓN}

7.3.4 Matando (efecto bactericida) o inhibiendo el crecimiento (efecto bacteriostático) de bacterias patógenas al liberar factores antimicrobianos como las bacteriocinas:

Uno de los efectos buscados al emplear probióticos es el mantenimiento o restauración de la microbiota del hospedador. La actividad antimicrobiana de los preparados probióticos depende de la producción de sustancias antimicrobianas inespecíficas como los ácidos orgánicos o el peróxido de hidrógeno y/o de la producción de toxinas antimicrobianas con diverso rango de acción (Millette, et al., 2007). Los ácidos grasos de cadena corta pueden difundir a través de la membrana, disociarse en el ambiente más alcalino del citoplasma y acidificarlo, lo cual explica su efecto inhibidor.

La fuerte actividad antimicrobiana de L. rhamnosus GG sobre Salmonella enterica serovar Thyphimurium es debida a la acumulación de ácido láctico que afecta al crecimiento y la expresión de factores de virulencia (Durant, et al., 2000).

El ácido láctico puede actuar además de bajando el $\mathrm{pH}$, aumentando la permeabilidad de la membrana externa de bacterias Gram-negativas e incluso capturando elementos esenciales para el crecimiento, como el hierro, dadas sus propiedades quelantes (Presser, et al., 1997).

Las bacteriocinas son potentes toxinas antimicrobianas de tipo proteico. El uso de cepas productoras de bacteriocinas como probióticos y agentes bioprotectores para competir con especies no deseadas está recibiendo un interés creciente (Gillor, et al., 2008).

Podemos hablar de bacteriocinas producidas por bacterias Gram-negativas, como las colicinas y microcinas, y de bacteriocinas producidas por bacterias Gram-positivas, entre ellas los lantibióticos, por ejemplo la nisina.

Las bacteriocinas producidas por las bacterias ácido lácticas son las mejor caracterizadas de entre las producidas por microorganismos Gram-positivos, dado el interés suscitado por su larga historia en la fermentación y conservación de productos lácticos y cárnicos. 
La producción de bacteriocinas en muchas cepas está controlada de forma dependiente de la densidad de población mediante mecanismos de quorum sensing usando una feromona peptídica secretada.

Como ejemplo tenemos la nisina, un péptido antimicrobiano de pequeño tamaño, alargado y con forma de tornillo que actúa frente a un amplio espectro de bacterias Gram-positivas y hongos. Se emplea ampliamente como agente antimicrobiano alimentario. Mata al formar poros, dispersando el potencial de membrana o provocando la pérdida de metábolitos pequeños de las células sensibles.

\section{PROCESO DE ADHESIÓN EPITELIAL:}

Como se ha venido discutiendo anteriormente, algunos de los efectos beneficiosos de los probióticos así como su posibilidad de colonizar, al menos transitoriamente, el tracto gastrointestinal se ven favorecidos en el caso de presentar una buena capacidad de adhesión. Es por eso que se trata de un rasgo deseable en un probiótico potencial, pues prolongaría el tiempo de residencia, favorecería la exclusión de patógenos y la interacción con las células del hospedador, siendo esto último importante en la protección del epitelio y en la inmunomodulación.

El lumen del intestino está literalmente recubierto por carbohidratos que son sitios potenciales de unión para las adhesinas bacterianas: la fracción polisacarídica de las mucinas y el glicocalix de las células del epitelio. El repertorio innato, controlado por el genoma del hospedador, determina la colonización inicial en las primeras etapas de la vida. Posteriormente pueden producirse cambios debidos a la actividad glicolítica de los primeros colonizadores y a los cambios en la expresión o actividad de las glicosiltransferasas endógenas resultado del diálogo bacteriahospedador. Los cambios del repertorio influyen en la aparición de nuevas especies colonizadoras. 


\section{INTRODUCCIÓN}

Parece ser que a ello se debe el carácter individual de la microbiota intestinal (Bourlioux, et al., 2003, Leser \& Molbak, 2009).

En el proceso de adhesión entran en juego interacciones inespecíficas, como las interacciones hidrofóbicas, que se establecen a distancias largas y son de carácter reversible. A distancias cortas ya pueden darse interacciones específicas del tipo ligando-receptor.

Los estudios iniciales o pioneros de adhesión a células epiteliales, mucus o componentes de la matriz extracelular intentaron determinar la naturaleza de las moléculas de la superficie bacteriana responsables de la adhesión, al someter las células del microorganismo objeto de estudio a tratamientos enzimáticos (ej. tripsina, pepsina), químicos (quelantes, oxidación por periodato) o físicos (calor).

Los planteamientos más recientes del estudio de los mecanismos de adhesión hacen uso de las secuencias de los genomas para predecir posibles componentes implicados en la adhesión y obtener mutantes con delecciones o disrupciones en dichos genes o bien clonar y purificar sus productos para ensayar la adhesión con los mismos (Deepika \& Charalampopoulos, 2010). En estos casos hay que tener en cuenta siempre que las especies bacterianas podrían contener toda una variedad de factores de adhesión, y en consecuencia redundancia de funciones.

\section{MODELOS PARA EL ESTUDIO DE LA ADHESIÓN DE PROBIOTICOS:}

La mayor parte de la información referente a la adhesión de probióticos procede de modelos in vitro y en mucha menor medida de estudios in vivo o ex vivo. Los estudios in vivo se basan en la administración de determinadas cepas bacterianas o combinaciones de las mismas a organismos, por ejemplo en estudios clínicos, para determinar mediante biopsias y/o recuentos en heces la persistencia de las mismas (Gianotti, et al., 2010). Unos pocos estudios han investigado ya las dinámicas de adhesión y colonización de diversos lactobacilos en modelos animales o humanos. 
Los lactobacilos aplicados exógenamente por lo general son capaces de colonizar el tracto gastrointestinal tan solo de forma temporal. Este hecho está relacionado con la resistencia a la colonización y el principio de exclusión de nicho, según el cual cada nicho del tracto gastrointestinal es colonizado por especies bien adaptadas al mismo. La microbiota intestinal de individuos adultos sanos es bastante estable; la colonización por especies aplicadas exógenamente es más estable en individuos recién nacidos o de corta edad cuya microbiota intestinal está todavía por desarrollarse (Schultz, et al., 2004).

Por su parte los estudios ex vivo se sirven de explantes de tejido intestinal obtenidos por resección (Ouwehand, et al., 2002, Vesterlund, et al., 2005). En estudios ex vivo con tejido humano, este se obtiene tras someter pacientes de diversas patologías a resección intestinal pudiendo emplearse las zonas dañadas y las zonas adyacentes como control. Ejemplos son el carcinoma rectal, la diverticulitis o enfermedades inflamatorias intestinales (Ouwehand, et al., 2003).

Entre los modelos in vitro se han utilizado líneas celulares de adenocarcinoma humano en cultivo (Resta-Lenert \& Barrett, 2003, Candela, et al., 2008). Dos de las líneas más ampliamente utilizadas son la Caco-2 y la HT-29. Las células de la línea celular Caco-2 forman una monocapa polarizada y diferenciada con muchas características de células absortivas del intestino delgado. Las de la línea HT-29 presentan características de células indiferenciadas intestinales y en el caso de ser HT-29 MTX (HT-29 que han sido sometidas a tratamiento con metotrexato) son capaces de diferenciarse en células caliciformes secretoras de mucus.

Otro modelo ampliamente empleado es el uso de (glico)proteínas inmovilizadas del mucus (Ouwehand, et al., 2001, Vesterlund, et al., 2006) o de la matriz extracelular (Styriak \& Nemcova, 2003, de Leeuw, et al., 2006), bien por separado, combinadas $o$ en mezclas que intentan asemejarse a la matriz extracelular (matrigel) (Horie, et al., 2002, Bouzaine, et al., 2005). 


\section{INTRODUCCIÓN}

Los resultados obtenidos en estudios in vitro son difíciles de extrapolar a la situación in vivo del tracto gastrointestinal, donde la adhesión se ve muy probablemente modificada por el sistema inmune del hospedador, la competición por el espacio y los nutrientes con la microbiota residente, el recambio de la mucosa y el flujo peristáltico (Lebeer, et al., 2008). Todo modelo in vitro es una simplificación, representa tan solo una porción del tracto a nivel longitudinal $y / o$ de las capas que componen la mucosa y no se amolda adecuadamente a las condiciones fisicoquímicas $\mathrm{y} / \mathrm{o}$ la complejidad microbiana del ambiente intestinal in vivo, lo que dificulta correlacionar los resultados.

La cuantificación de la adhesión puede hacerse por métodos de cultivo, por contaje microscópico, por métodos de marcaje radioactivo o fluorescente e incluso mediante detección inmunológica. Los sistemas modelo de estudio de la adhesión bacteriana distan mucho de estar estandarizados, aunque pese a ello distintos factores responsables de la adhesión a diferentes partes de la mucosa han podido ser caracterizados en detalle en especies de lactobacilos (Velez, et al., 2007).

\section{SUPERFICIE CELULAR DE LOS LACTOBACILOS:}

La superficie de las células bacterianas (Figura 6) determina su interacción con la mucosa gastrointestinal influyendo en su localización y en su funcionalidad. Se ha sugerido que la capacidad de adherirse a la mucosa podría influir en las relaciones con otras bacterias y con el hospedador, en el primer caso alterando la composición local de la microbiota, y en el segundo interaccionando con el sistema inmunitario del hospedador.

De hecho, cada vez es más patente que el sistema inmunitario innato de la mucosa gastrointestinal es capaz de reconocer moléculas específicas de diferente naturaleza presentes en la superficie bacteriana (Microbial Associated Molecular Patterns o MAMPs) o componentes bacterianos liberados al medio (por ejemplo, DNA), modulando así su respuesta. 


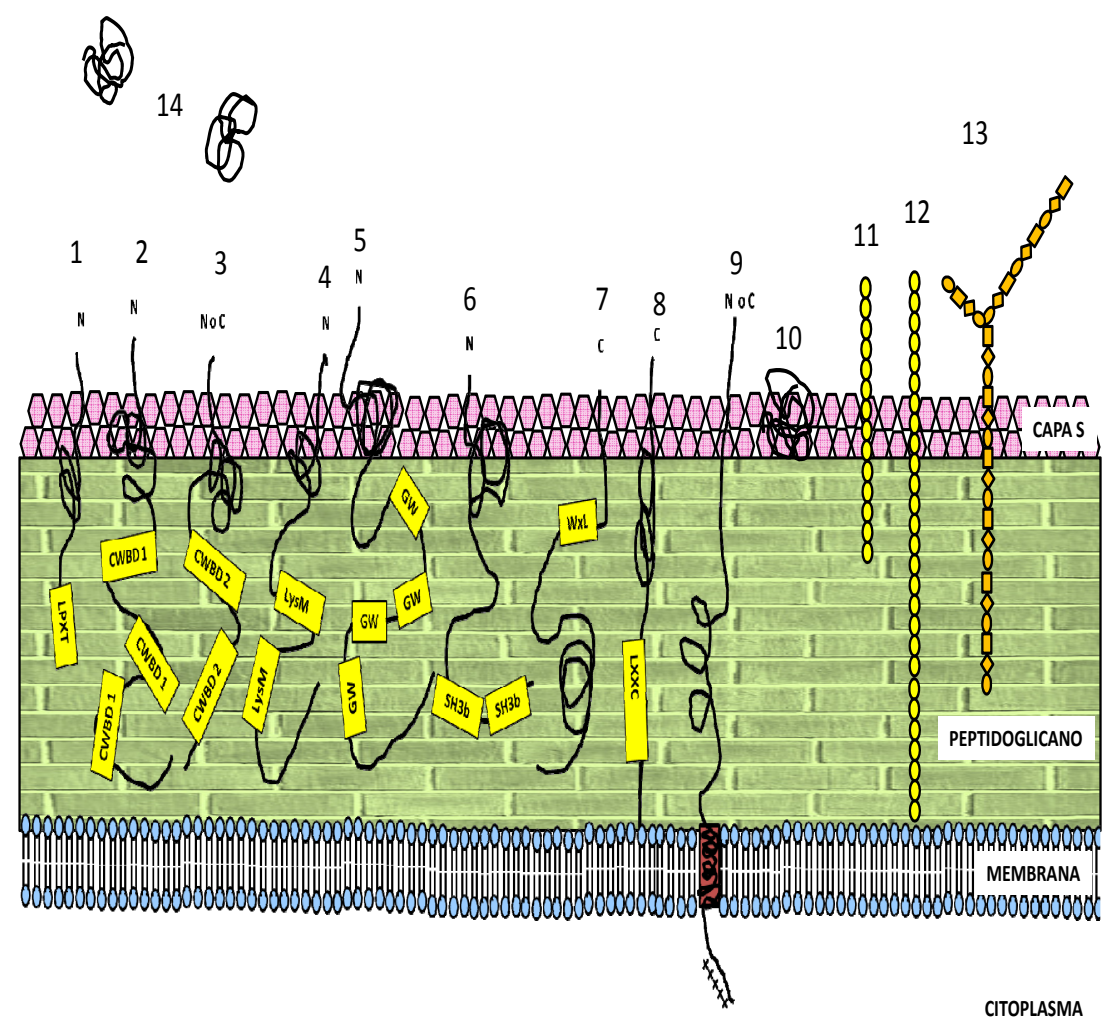

Figura 6. Esquema de la superficie de los lactobacilos y las diferentes moléculas/dominios proteícos implicados en procesos de adhesión y anclaje a la superficie. Adaptado de Exported proteins in probiotic bacteria: adhesión to intestinal surfaces, host immunomodulation and molecular cross-talking with the host (Sanchez, et al., 2008) y de Protein cell surface display in Gram-positive bacteria: from single protein to macromolecular protein structure (Desvaux, et al., 2006). 1: Proteínas ancladas covalentemente a la pared por acción de las sortasas, 2: Proteínas con dominio de unión a colina (Cell Wall Binding Domain 1), 3: Proteínas con Cell Wall Binding Domain de tipo 2, 4: Proteínas LysM, 5: Proteínas GW, 6: Proteínas SH3b, 7: Proteínas WxL, 8: Lipoproteínas , 9: Proteínas insertadas en membrane por hélices hidrofóbicas en posición $\mathrm{N}$ - o C-terminal, 10: Proteínas sin anclaje, 11: Ácidos teicoicos de pared, 12: Ácidos lipoteicoicos, 13: Polisacáridos, 14: Proteínas secretadas. 


\section{INTRODUCCIÓN}

El epitelio intestinal está equipado con receptores tanto transmembrana como intracitoplásmicos denominados receptores de reconocimiento de patrón, los PRRs (Pattern Recognition Receptors), pertenecientes a la inmunidad innata, responsables de reconocer $y$ unir los diferentes MAMPs. La densidad de los PRRs es superior en las criptas, las cuales están mejor defendidas.

Los receptores transmembrana incluyen la familia de los TLR (Toll-like receptors) y muestrean tanto el espacio extracelular como el endosoma. A nivel intracelular se encuentran los NODs, (Nucleotidebinding oligomerization domain-like receptors) o NLRs.

En función de la naturaleza del estímulo y del organismo que lo haya provocado se ponen en marcha rutas de señalización asociadas tanto con el sistema inmune innato como con el adaptativo, que pueden desembocar en una respuesta atenuada ante la microbiota comensal, en una respuesta inflamatoria frente a microorganismos patógenos o incluso en una apoptosis de la célula del hospedador.

Este diálogo microbiota-hospedador busca el asentamiento de especies comensales y prevenir que las especies patógenas constituyan nichos para su persistencia y proliferación (Sharma, et al., 2010). Mutaciones o expresión anormal de los receptores TLR o NOD se asocian con la aparición de enfermedades inflamatorias intestinales (Hsiao, et al., 2008). La envoltura celular bacteriana está en contacto con un ambiente cambiante y es capaz de responder a variaciones en el mismo con cambios en su estructura y función.

\subsection{PARED CELULAR:}

La pared celular es una estructura rígida exterior a la membrana plasmática. La pared es importante en la protección frente a la lisis osmótica aguantando las presiones internas que en bacterias Gram-positivas pueden alcanzar las 20 atmósferas y también confiere cierta protección frente a sustancias tóxicas, además de ser importante en la determinación de la forma y servir de soporte o andamiaje para el anclaje de polímeros secundarios 
como ácidos teicoicos, polisacáridos y proteínas que contribuyen a las propiedades fisicoquímicas netas de hidrofobicidad y carga. Esa decoración molecular de la pared le confiere propiedades específicas de especie y cepa.

\subsubsection{Peptidoglicano:}

El peptidoglicano es el principal componente de la pared celular y consiste en cadenas lineales de polisacáridos cuyos monómeros alternantes son $\mathrm{N}$-acetil-glucosamina (NAG) y $\mathrm{N}$-acetilmurámico (NAM) unidos mediante enlaces $\beta(1-4)$. Un extensivo entrecruzamiento de los polímeros lineales por péptidos cortos unidos a los monómeros NAM le confiere una estructura en forma de malla y le otorga una gran solidez.

Los primeros dos residuos de aminoácido suelen ser L-alanina y D-glutamina o D-isoglutamina. En la tercera posición encontramos L-lisina en el caso de cocos Gram-positivos (como Streptococcus o Staphylococcus) o ácido meso-diaminopimélico en bacilos Grampositivos (como Listeria y Bacillus) y en bacterias Gram-negativas. En el primer caso el puente cruzado entre cadenas peptídicas suele estar constituido por dos a cinco residuos de glicina y serina, mientras que en el segundo caso se trata de enlaces directos entre los mesodiaminopimelatos.

El número de capas es variable y su grosor total está comprendido entre 20 y $80 \mathrm{~nm}$. La longitud de las cadenas así como el grado de entrecruzamiento varían en función de la especie, la cepa y las condiciones de crecimiento.

Podemos encontrar modificaciones tanto en las propias hebras de glicano como en los péptidos asociados y las regiones puente. Estas modificaciones son importantes en la fisiología y la interacción con el hospedador, pudiendo incrementar la resistencia a antibióticos, a enzimas degradativas del hospedador y colaborar a evitar la inmunidad innata. Dichas modificaciones son en muchos casos específicas de especie debido a la expresión de enzimas de síntesis, degradación y modificación únicas. 


\section{INTRODUCCIÓN}

El peptidoglicano es susceptible asimismo de ser modificado en respuesta a cambios en las condiciones ambientales. Las hidrolasas de peptidoglicano lo remodelan continuamente durante el crecimiento. Un conjunto de enzimas glicosidasa, amidasa y endopeptidasas confieren la capacidad de degradar el peptidoglicano y de reciclar los glicanos y aminoácidos del mismo. Dichas enzimas están implicadas en la renovación de la pared, generando espacio para incorporar nuevos disacáridos o para sistemas de secreción u otras estructuras, en la separación de las células hijas y en la autólisis en fase estacionaria. Las hidrolasas también pueden conducir a la liberación de muropéptidos bioactivos. La habilidad de los muropéptidos de modular respuestas en el hospedador se debe a que los eucariotas no producen peptidoglicano pero han evolucionado múltiples mecanismos de detección tanto del peptidoglicano intacto como de fragmentos del mismo.

Entre los diversos receptores de peptidoglicano o muropéptidos se cuentan los anteriormente mencionados TLRs y NLRs, así como los PGRPs (Peptidoglican Recognition Proteins). En la superficie de la célula eucariota se encuentra el receptor TLR-2 (Toll Like Receptor 2) capaz de reconocer el peptidoglicano o moléculas asociadas con el mismo. NOD-1 reconoce constituyentes del peptidoglicano exclusivamente de bacterias Gram-negativas, mientras que NOD-2 reconoce peptidoglicano tanto de Grampositivas como de Gram-negativas.

Algunos PGRPs de humanos se unen directamente al peptidoglicano de microorganismos patógenos invasores y se piensa que podrían llegar a interferir en su síntesis. Otras cuentan con una actividad $\mathrm{N}$-acetil-muramoil-L-alanina amidasa, lo que les permite digerir bacterias intactas y/o reducir la respuesta pro-inflamatoria en el hospedador.

En los últimos años se han venido identificando y estudiando múltiples vías empleadas por el hospedador para la detección del peptidoglicano o muropéptidos. 
El que estén conservadas en ratones, hombres y otros eucariotas nos da una idea de su importancia, aunque también suponen una fuente de presión selectiva para el desarrollo de mecanismos de virulencia en microorganismos patógenos para evadir esta detección (Humann \& Lenz, 2009).

\subsection{2 Ácidos teicoicos:}

Los ácidos teicoicos son polímeros de polialcohol (glicerol o ribitol) unidos mediante enlaces fosfodiester. Representan hasta el $50 \%$ del peso seco de la pared y sus grupos fosfato son responsables en gran medida de la carga negativa de las bacterias Gram-positivas dado que se trata de ácidos fuertes.

Hay ácidos teicoicos de pared, unidos covalentemente a monómeros de ácido $\mathrm{N}$-acetil-murámico; ácidos lipoteicoicos unidos a través de un glicolípido a la membrana plasmática o de forma débil a la pared, e incluso podemos encontrar ácidos teicoicos liberados al medio extracelular.

Junto con el peptidoglicano contribuyen a determinar la porosidad, elasticidad y carga electrostática de la envoltura celular. Pero su carga negativa contribuye también a la homeostasis de cationes, principalmente de $\mathrm{Mg}^{2+}$, requeridos para el crecimiento, $\mathrm{y}$ de protones fundamentales para el mantenimiento del gradiente de la pared celular. Son esenciales para la supervivencia celular e influyen en la morfología, control de la elongación, disposición de los septos y separación de las células hijas, posiblemente debido a que la maquinaria de ensamblaje y degradación del peptidoglicano resulta afectada en caso de faltar.

En el caso de L. casei tan solo hay ácidos lipoteicoicos, lo que sugiere que son suficientes para desempeñar todas las importantes funciones biológicas de los ácidos teicoicos. Los ácidos lipoteicoicos de lactobacilos son variables en cuanto a la longitud de la cadena, el porcentaje y tipo de sustituciones y posiblemente en cuanto a la naturaleza del ancla lipídica. 


\section{INTRODUCCIÓN}

Están compuestos por poliglicerol fosfato y están decorados al menos por D-alanil ésteres que con la carga positiva de los grupos amino, compensan en parte la carga negativa del esqueleto fosfato.

La inactivación del operón implicado en la D-alanilación (operon $d / t$ ), presente en todos los genomas secuenciados de lactobacilos, afecta directa o indirectamente a su composición química. Las variaciones pueden afectar a la longitud (aumento de tres veces en $L$. plantarum WCFS1, reducción de 1,7 a 8 veces en $L$. rhamnosus GG o sin variaciones en $L$. reuteri 100-23), a la aparición de glucosilaciones como sustituyentes (pasando de ser indetectables a constituir el $24 \%$ del total de las sustituciones en $L$. plantarum WCFS1, aumentando cinco veces en $L$. reuteri 100-23, pero sin cambios apreciables en $L$. rhamnosus GG) y a la naturaleza del ancla lipídica (en el caso de L. rhamnosus GG). Se observa también una sensibilidad aumentada frente a péptidos antimicrobianos cargados positivamente (Palumbo, et al., 2006, Perea Velez, et al., 2007, Walter, et al., 2007).

\subsubsection{Polisacáridos de pared:}

Los polisacaridos suelen ser neutros, pudiendo tener carácter ácido de estar ramificados con grupos aniónicos como glicerol fosfato. Se distinguen tres grupos: los de la cápsula, una estructura rígida externa a la pared; los de pared, ya estén unidos covalente o no covalentemente y por último los extracelulares o secretados.

Aunque dicha división parece en cierto modo artificial al depender en gran medida de las condiciones de crecimiento.

En lactobacilos son generalmente heteropolisacáridos que pueden diferir en los monómeros, el tipo de enlace y las ramificaciones y sustituciones. La complejidad queda reflejada en la agrupación de los genes implicados en su síntesis en clusters de gran tamaño e incluso en la existencia de varios clusters por cepa. 
Estos polisacáridos podrían ocultar otros polímeros de superficie implicados en adhesión, como sugiere la pérdida de una capa difusa rodeando la pared de L. johnsonii NCC 533 y el aumento del tiempo de residencia en el tracto gastrointestinal al deleccionarse por entero el cluster responsable de su síntesis (Denou, et al., 2008).

\subsubsection{Proteínas de superficie:}

Las proteínas de la superficie de las bacterias constituyen un grupo diverso de moléculas con importantes funciones como adherencia, señalización, invasión e interacción con el sistema inmune del hospedador o el ambiente. Las proteínas son las que hacen única a la envoltura celular. De ahí la importancia que la caracterización de las proteínas de superficie tiene a la hora de comprender la ecología intestinal.

Pueden estar asociadas a la membrana o a la pared, bien de forma covalente o no covalente (Figura 6). A la membrana pueden anclarse por segmentos hidrofóbicos transmembrana en $\mathrm{N}$ ○ Cterminal o ser lipoproteínas unidas a ácidos grasos de cadena larga de la membrana plasmática. A la pared pueden unirse covalentemente por transpeptidación mediante la acción de las enzimas sortasas o pueden estar ancladas no covalentemente por diferentes dominios de unión a la pared o por interacciones con otras proteínas o apéndices superficiales.

\subsubsection{Proteínas unidas a la membrana por inserción de segmentos hidrofóbicos:}

Las proteínas que cuentan con un péptido señal en el extremo N-terminal pueden sufrir el ataque de la peptidasa señal de tipo I y ser liberadas o bien quedar retenidas en la membrana mediante la inserción de hélices transmembrana compuestas por aminoácidos hidrofóbicos seguidos o precedidos por residuos cargados positivamente. Los segmentos hidrofóbicos pueden integrarse de uno en uno o en pares, lo que se denomina modelo en horquilla. Las hay de tipo I o II en función de que la orientación sea $\mathrm{N}$ dentro C fuera o $\mathrm{N}$ fuera C dentro (Bath, et al., 2005). 


\section{INTRODUCCIÓN}

\subsubsection{Lipoproteínas:}

Las lipoproteínas presentan en $\mathrm{N}$-terminal un péptido señal de tipo II con la secuencia conservada lipobox (LXXC, donde $X$ es cualquier aminoácido) que incluye un residuo de Cys tras el sitio de corte de la peptidasa señal. La existencia de esta secuencia conservada ha facilitado enormemente la identificación de lipoproteínas putativas por análisis de secuencias génicas.

Tras ser translocado el precursor, la prolipoproteína diacilglicerol transferasa añade un grupo diacilglicerol de un glicerofosfolípido al grupo SH del residuo de Cys de la secuencia lipobox. Tras esto, la proteína se inserta en la bicapa lipídica y la peptidasa señal II corta y libera la proteína madura. Dicha proteína resulta aminoacilada en su Cys $\mathrm{N}$-terminal por la fosfolípido/apolipoproteina transacilasa lo que conduce a su anclaje a un ácido graso de cadena larga.

Este mecanismo de lipidación es de particular importancia en bacterias Gram-positivas al carecer estas de una membrana externa retentiva. Las subunidades de unión a soluto de sistemas de transporte de nutrientes son habitualmente ancladas de esta manera (Sutcliffe \& Harrington, 2002).

\subsubsection{Proteínas ancladas covalentemente a la pared por acción de las sortasas:}

Muchas de las proteínas de superficie de las bacterias Grampositivas, incluyendo aquellas que constituyen los pili, son ancladas covalentemente a la pared celular mediante la acción de las enzimas sortasas, unas tiol-transpeptidasas ancladas a la membrana (figura 7).

Los sustratos de acción de estas enzimas cuentan con un péptido señal $\mathrm{N}$-terminal y con una señal de direccionamiento a pared en C-terminal con 3 regiones diferenciadas: un motivo pentapeptídico reconocible por las enzimas sortasas (LPXTG, NPQTN u otras variantes) seguida de un dominio hidrofóbico y una cola constituida por residuos cargados positivamente. 
El péptido señal las dirige por la vía secretoria, quedando retenidas en la membrana celular gracias al dominio hidrofóbico y al ancla constituida por los residuos positivos.

La reacción se lleva a cabo en 2 pasos:

i. Acilación: con la proteína retenida en la membrana, la sortasa reconoce el motivo LPXTG; el grupo tiolato del residuo de Cys de su sitio activo lleva a cabo un ataque nucleofílico sobre el carbonilo de la treonina formando un enlace tioester entre la enzima y el sustrato.

ii. Desacilación: el grupo amino del puente cruzado de pentaglicina del lípido II (precursor de la síntesis del peptidoglicano), \{undecaprenol-PP-MurNAc-[L-Ala-D-iGln-Llys $\left(\mathrm{NH}_{2} \text {-Gly }\right)_{5}$-D-Ala-D-Ala]- $\left.\left.\beta(1-4)-G \mid c N A c\right]\right\}$, ataca el enlace tioester de la enzima acilada regenerándola y uniéndose covalentemente al sustrato proteico. La proteína unida al lípido II es incorporada al sáculo de mureina mediante reacciones de transpeptidación y transglicosilación llevadas a cabo por las proteínas de unión de penicilina o PBPs (Penicillin Binding Proteins).

Se han identificado sortasas en prácticamente todas las bacterias Gram-positivas y actualmente se propone su clasificación en 4 grupos (Dramsi, et al., 2005, Dramsi, et al., 2008). Los miembros de estas cuatro clases estructurales presentan 3 dominios conservados: D1, D2 y D3, aparte de lo cual cada clase de sortasas posee un patrón específico de aminoácidos conservados.

Los dos aminoácidos clave en el sitio catalítico, una histidina y una cisteína, se encuentran respectivamente en los motivos D2 y D3. El anillo imidazol de la histidina con toda probabilidad favorece la formación del tiolato en el residuo de cisteína y el consiguiente ataque nucleofílico sobre el grupo carbonilo del enlace peptídico objeto del corte en la secuencia reconocible por sortasas. 


\section{INTRODUCCIÓN}

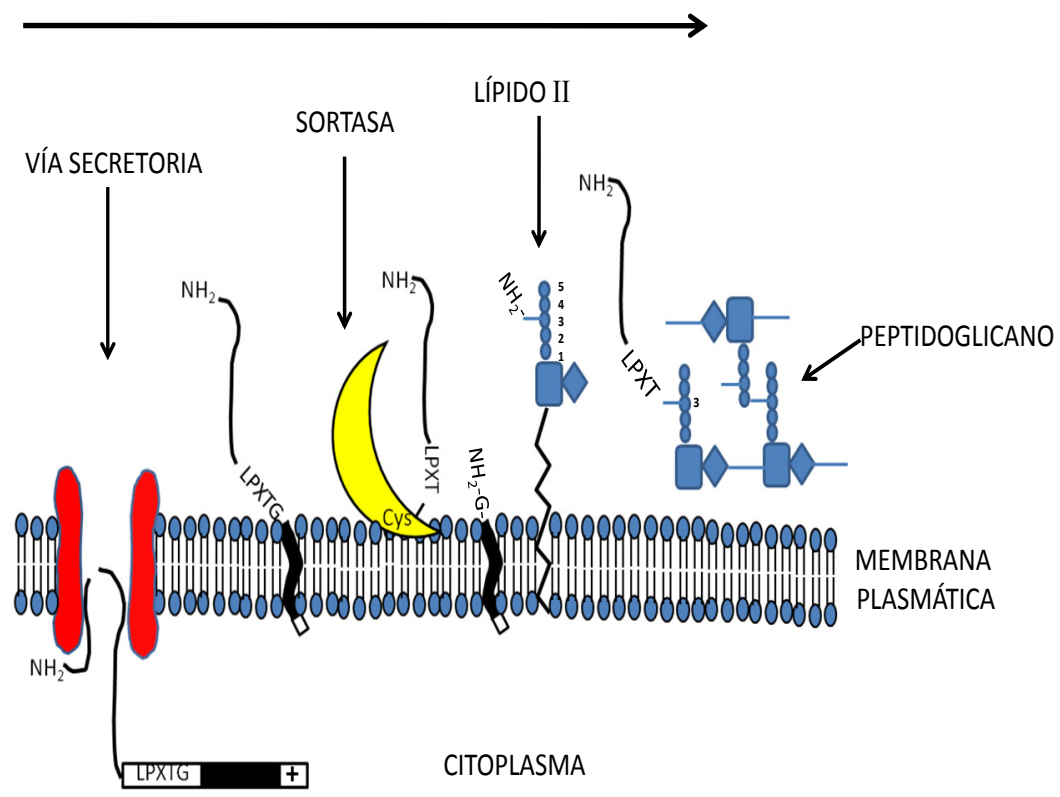

Figura 7. Mecanismo de acción de las sortasas. Adaptado de Covalent attachment of proteins to peptidoglycan (Dramsi, et al., 2008) y de Sortases and the art of anchoring proteins to the envelopes of Gram-positive bacteria (Marraffini, et al., 2006).

Las sortasas del grupo A o subfamilia 1 tienen como sortasa prototípica a SrtA de Staphylococcus aureus. Suele haber una única copia por genoma, su gen no se encuentra por regla general agrupado con los de sus sustratos, se expresa constitutivamente y es una enzima de rango amplio responsable de anclar la mayoría de sustratos que poseen un motivo C-terminal con secuencia consenso LPXTG (donde $X$ es cualquier aminoácido).

El grupo B o subfamilia 2, cuya sortasa prototípica es SrtB de S. aureus, es el grupo más pequeño, está presente en algunos Grampositivos de bajo contenido en $\mathrm{G}+\mathrm{C}$ y reconoce un motivo diferente (NPQTN, NAKTN, NPQTG). Se localiza en clusters junto con sus sustratos potenciales. 
Otra diferencia respecto a las sortasas de tipo $A$ es que no unen las proteínas al precursor del peptidoglicano péptido II, sino que lo unen a las cadenas laterales de pentaglicina no entrecruzadas del peptidoglicano maduro (Marraffini \& Schneewind, 2005).

Participan en la respuesta a condiciones de deprivación de hierro estando sus sustratos implicados en su adquisición.

El grupo C o subfamilia 3 es el más amplio y heterogéneo. Se encuentra en bacterias Gram-positivas tanto de alto como de bajo contenido en $\mathrm{G}+\mathrm{C}$. Suele haber varias copias por genoma agrupadas en clusters junto con sus sustratos potenciales lo que sugiere una coordinación regulada. Presentan un dominio hidrofóbico adicional en C-terminal y el motivo reconocido es LPXTGG en el $80 \%$ de los casos.

Son enzimas polimerizantes encargadas de la formación de pili o fimbria en múltiples bacterias Gram-positivas, estructuras supramoleculares que generalmente presentan capacidad adhesiva en su punta. Es el primer ejemplo de sortasas cuya reacción enzimática usa tan solo polipéptidos como sustratos en lugar del binomio proteína-peptidoglicano (Ton-That \& Schneewind, 2003).

El grupo $D$ incluye las subfamilias 4 y 5 que reconocen respectivamente los motivos LPXTA y LAXTG. Se encuentran en bacterias tanto de alto como de bajo contenido en $\mathrm{G}+\mathrm{C}$. Parecen jugar un papel bajo condiciones de desarrollo específicas y se localizan en genomas de organismos con ciclos de diferenciación (Bacillus, Clostridium, Streptomyces) (Marraffini \& Schneewind, 2006).

Los sustratos de las sortasas funcionan como adhesinas, internalinas, factores para evadir la coagulación y el sistema inmune, enzimas hidrolíticos (proteasas, glicosidasas), transportadores de nutrientes a través de la pared celular. Sin ellos, la mayoría de los microorganismos Gram-positivos patógenos no son capaces de llevar a cabo una infección y por ello las sortasas se plantean como una diana para terapias anti-infectivas (Maresso \& Schneewind, 2008). 


\section{INTRODUCCIÓN}

10.1.4.4 Proteínas ancladas de forma no covalente por dominios específicos que reconocen algún componente de la pared (CWBD1, CWBD2, LysM, GW, SLHD, WxL, SH3b):

CWBD1: Cell Wall Binding Domain 1 o dominio de unión a colina. Este motivo reconoce residuos de colina de los ácidos teicoicos o lipoteicoicos y se une a los mismos. Está constituido por varias repeticiones imperfectas de unos 20 aminoácidos y con residuos aromáticos conservados. El número de copias oscila entre 1 y 50. Siendo lo más común de 5 a 10 repeticiones en tándem. Se encuentran principalmente en enzimas extracelulares como autolisinas y muramidasas (Wren, 1991).

CWBD2: Cell Wall Binding Domain 2. De unos 100 aminoácidos de longitud, de 1 a 3 copias en tándem localizadas en $\mathrm{N}$ o C-terminal. Queda por determinar con qué componentes de la pared celular interacciona este dominio. Se encuentra en autolisinas, adhesinas y algunas proteínas de la capa S. En las bacterias Grampositivas se encuentra sólo entre los miembros de las familias Bacillaceae y Clostridiaceae (Waligora, et al., 2001, Desvaux, et al., 2006).

LysM: Dicho dominio lo presentan muchas enzimas extracelulares implicadas en el metabolismo de la pared celular. El nombre procede de su presencia en varias lisinas bacterianas. Aparte de participar en la degradación de la pared celular pueden tener otras funciones diferentes e incluso una función dual, por ejemplo bacteriolítica y adhesiva en la autolisina aaa de S. aureus (Heilmann, et al., 2005). El dominio LysM une directamente el peptidoglicano y dicha unión se ve dificultada por otros polímeros secundarios de la pared celular, posiblemente los ácidos lipoteicoicos.

Consta de 40 aminoácidos y el número de repeticiones en tándem oscila entre una y seis. Generalmente se localiza en la región $\mathrm{N}$ o C-terminal. 
Por ejemplo en la autolisina AcmA de Lactococcus lactis se encuentra en su región C-terminal, puede deleccionarse sin eliminar la capacidad de la enzima de digerir pared celular in vitro y la obtención de proteínas quiméricas a las que se les añade el citado dominio permite su anclaje al peptidoglicano tanto en L. lactis como en otras bacterias Gram-positivas (Steen, et al., 2003).

Módulo GW: posee unos 80 aminoácidos aproximadamente, conteniendo el dipéptido Gly-Trp. Suele encontrarse en copias múltiples. A mayor número de copias más fuerte es la adhesión a la pared celular. Pueden interactuar con ácidos lipoteicoicos. Se encuentran principalmente en autolisinas, pero también pueden estar implicadas en adhesión a células eucariotas (Cabanes, et al., 2002).

SLHD: S-Layer Homology Motif. Descubierto originalmente en proteínas de la capa regular cristalina (S-layer) observada en la superficie de algunos procariotas. Se trata de una estructura cristalina, monomolecular cuyas subunidades son proteínas. Cubre aproximadamente la totalidad de la superficie celular, presenta simetría cuadrada o hexagonal y puede autoensamblarse in vitro y se considera que tiene una función protectora.

Al ser unión no covalente puede extraerse usando agentes desnaturalizantes como el $\mathrm{LiCl}$ o el cloruro de guanidinio. Se unen muy fuertemente de forma no covalente a polímeros secundarios de pared piruvilados o con el mismo peptidoglicano.

Los dominios suelen estar compuestos por uno a tres motivos de unos 50 aminoácidos de longitud, localizados en $\mathrm{N}$ o C-terminal. Muchos lactobacilos tienen múltiples genes que codifican proteínas de la capa $S$, pudiendo expresarse de forma simultánea o diferencial (Avall-Jaaskelainen \& Palva, 2005). 


\section{INTRODUCCIÓN}

Dominio SH3b: Son la contrapartida procariota de los dominios eucariotas SH3 (bacterial SH3-like domain). Se localizan en la región C-terminal y se piensa que reconocen secuencias específicas en los puentes cruzados del peptidoglicano de pared, que están implicados en la unión al mismo y que la función principal de las proteínas que los contienen es el recambio de la pared celular (Lu, et al., 2006).

Los dominios SH3b mejor estudiados hasta la fecha son los de las hidrolasas de mureina de Staphylococcus lisostafina y ALE-1 que reconocen y cortan el interpéptido de pentaglicina que constituye los puentes cruzados en esta especie (Lu, et al., 2006). Eldholm y colaboradores estudiaron el dominio SH3b presente en la hidrolasa de mureina $\mathrm{CbpD}$ de pneumococo. Construyeron proteínas de fusión de la proteína verde fluorescente (GFP) con estos dominios, las cuales fueron capaces de unirse a sáculos de mureina a los que se les habían retirado los ácidos teicoicos demostrando que reconocían y unían la porción de peptidoglicano de la pared celular (Eldholm, et al., 2010).

Dominio WxL: Es un dominio de unión a pared celular localizado en C-terminal. Se encuentran en clusters junto con genes que codifican proteínas con dominios de anclaje a membrana en Cterminal y motivos de tipo LPXTG reconocibles por sortasas, lo que sugiere que forman un complejo proteico extracelular.

Se han encontrado en bacterias Gram-positivas asociadas a plantas, conteniendo proteínas asociadas a adquisición de fuentes de carbono, lo que sugiere su participación en la degradación y utilización de oligosacáridos y polisacáridos de plantas (Siezen, et al., 2006). 


\section{INTRODUCCIÓN}

\subsubsection{Moonlighting Proteins:}

El concepto de moonlighting proteins o "proteínas pluriempleadas" hace referencia a proteínas para las que se han descrito más funciones aparte de aquella con la que inicialmente fueron caracterizadas. Un caso concreto son proteínas habitualmente citoplásmicas que pueden ser exportadas y quedar expuestas en la superficie bacteriana pese a carecer de señales detectables de secreción y retención.

Estas proteínas pluriempleadas pueden estar implicadas en roles importantes para la fisiología del tracto gastrointestinal como la unión del plasminógeno y la agregación de patógenos.

Recientemente se ha visto que la GAPDH y la enolasa presente en la superficie de bifidobacterias y lactobacilos probioticos son capaces de activar el plasminógeno, por lo que se sugiere que podrían de este modo estar interfiriendo con la interacción entre el plasminógeno y microorganismos patógenos los cuales usan la activación del mismo para incrementar su capacidad de captación de nutrientes así como su capacidad invasiva (Hurmalainen, et al., 2007).

Bergonzelli y colaboradores detectaron la presencia en superficie de la chaperona GroEL en L. Johnsonii La1. Una forma recombinante de dicha proteína presentó una gran capacidad de agregación del patógeno gástrico Helicobacter Pylori.

Lo que junto con su capacidad de unirse al mucus llevó a sugerir su posible implicación en disminuir la carga bacteriana de este patógeno favoreciendo su eliminación junto con el mucus (Bergonzelli, et al., 2006). 


\section{INTRODUCCIÓN}

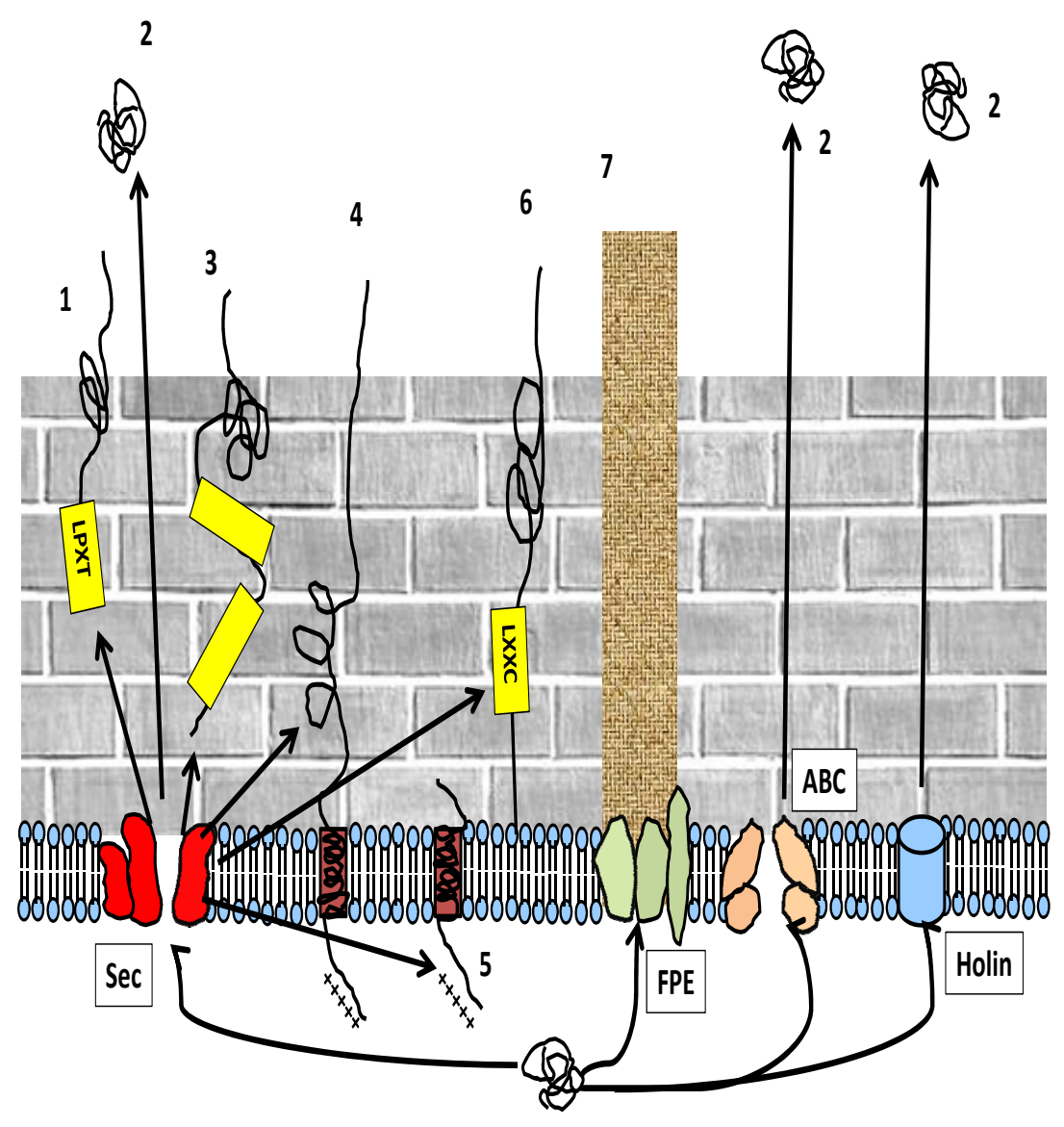

Figura 8. Sistemas de secreción de proteínas en lactobacilos. Adaptado de The extracelular biology of the lactobacilli (Kleerebezem, et al., 2010). 1: Proteínas ancladas covalentemente a pared por acción de las sortasas. 2: Proteínas liberadas al medio extracelular por los sistemas Sec, ABC o Holin. 3: Unidas no covalentemente a pared al presentar determinados motivos/dominios de unión como LysM, WxL o SLHD. 4: Proteínas de superficie ancladas a membrana por segmentos hidrofóbicos. 5: Proteínas integrales de membrana. 6: Proteínas ancladas covalentemente a lípidos de la membrana. 7: Proteínas que forman parte de apéndices de la superficie celular como los pseudopili de competencia. 


\section{SISTEMAS DE SECRECIÓN DE PROTEÍNAS EN LACTOBACILOS:}

El estudio de los genomas secuenciados de lactobacilos aplicando la homología de secuencias y búsqueda de dominios proteicos muestra que estas bacterias contienen genes que codifican los sistemas $\mathrm{Sec}$, FPE, Peptide Efflux $A B C$ y Holin de secreción de proteínas (Kleerebezem, et al., 2010) (Figura 8). A diferencia de lo que sucede en bacterias Gram-negativas, en las Gram-positivas las proteínas tan solo deben atravesar una membrana para llegar al ambiente extracelular. Por esta razón, se utilizan bacterias Gram-positivas, como por ejemplo diversas especies de Bacillus, para la producción industrial de proteínas extracelulares con rendimientos de hasta varios gramos por litro de medio de cultivo.

\subsection{SEC (Secretion):}

Es el principal sistema de secreción de proteínas a través de la membrana citoplásmica de bacterias Gram-positivas. Consta de un canal integrado en membrana (SecYEG), un motor ATPasa (SecA) y un complejo heterotrimérico implicado en regular la actividad del motor (SecDF-YajC). Adicionalmente el complejo heterotrimérico podría asociarse a YidC, importante en la inserción de proteínas integrales de membrana.

Los genomas de lactobacilos codifican copias únicas de los elementos implicados en el reconocimiento de la señal que dirigen la proteína precursora hacia la translocasa.

Todas las proteínas dirigidas por esta vía cuentan con un péptido señal $\mathrm{N}$-terminal con 3 regiones: la $\mathrm{N}$ con residuos cargados positivamente, la $\mathrm{H}$ con $15-25$ residuos hidrofóbicos y la $\mathrm{C}$ que puede contener el sitio de corte de la peptidasa señal.

En lactobacilos existe un número variable de genes de peptidasa señal de tipo I (de 1 a 3), la cual reconoce el sitio de corte AXAA. Todos los genomas de lactobacilos codifican una única peptidasa señal de tipo II que como se comentó anteriormente reconoce la secuencia LXXC, también llamada lipobox. 


\section{INTRODUCCIÓN}

Las preproteínas se translocan desplegadas a través del canal hidrofílico formado por los productos de los genes sec, tras lo cual el péptido señal es retirado proteolíticamente y la proteína se pliega con la ayuda de chaperonas moleculares (van Wely, et al., 2001).

\subsection{Holin (Formador de poros):}

Son pequeñas proteínas integrales de membrana implicadas principalmente en la secreción de enzimas murolíticos que participan en la autolisis. Son codificados frecuentemente por genomas de bacteriófagos aunque también pueden encontrarse en los genomas de lactobacilos en un contexto génico relacionado con la lisis celular. Comparten características estructurales y funcionales pese a su baja similitud de secuencia. Los criterios empleados para identificar holinas en los genomas de lactobacilos son (Wang, et al., 2000):

- Tamaño comprendido entre 60 y 150 aminoácidos

- Presencia de uno a cuatro segmentos transmembrana.

- Extremo N-terminal hidrofílico

- Extremo C-terminal polar y de carga elevada.

- Similitud de secuencia con la de holinas conocidas u otras proteínas con dominio holina de al menos un $50 \%$

\subsection{FPE (Fimbrilin-Protein Exporter):}

Forma parte de la ruta Com de desarrollo de la competencia en algunas bacterias. Los genes de este sistema participan en la exportación y el ensamblaje de prepilinas de tipo IV, pero no constituyen un pili de tipo cuatro propiamente dicho, sino una estructura que atraviesa la pared celular y permite la presentación de ADN exógeno a la maquinaria de translocación y su captación a través de la membrana (Chen \& Dubnau, 2004).

En Bacillus subtilis el sistema FPE consiste en siete genes comG localizados en el operon comGA-GG y otro gen no ligado, el comC. Todos los genomas de Lactobacillus codifican copias únicas del operón comGA-GC y la mayoría también un homólogo de comC, por lo que los principales componentes de la ruta FPE están presentes. 
Adicionalmente se han podido identificar en genomas secuenciados de lactobacilos genes codificantes de otras prepilinas o de proteínas adicionales implicadas en la captación de ADN exógeno. Los precursores se translocan mediante un evento de corte llevado a cabo por una peptidasa señal específica en el lado citoplásmico de la membrana.

\subsection{Peptide Efflux ABC Transporters:}

Comprenden subfamilias específicas de transportadores $A B C$ implicados principalmente en la exportación de péptidos antimicrobianos (lantibióticos, bacteriocinas y péptidos de competencia) (Havarstein, et al., 1995), capaces de exportar sustancias proteicas. La mayoría de los genes que codifican bacteriocinas parecen estar asociados genéticamente con genes codificantes de exportadores ABC (de Jong, et al., 2006).

\section{ADHESINAS DE LACTOBACILOS:}

La investigación sobre los procesos de adhesión al epitelio intestinal en lactobacilos ha establecido la implicación de diversas proteínas en el mecanismo. Los estudios de adhesinas proteicas se han llevado a cabo principalmente en patógenos, dónde estas juegan un papel crucial en la virulencia. En patógenos se han identificado multitud de adhesinas específicas que median la capacidad de adherirse a los epitelios e invadir diferentes órganos al interaccionar con, por ejemplo, proteínas de la matriz extracelular (Moschioni, et al., 2010).

Homólogos a estas adhesinas típicas de patógenos no han sido descritos en bacterias lácticas. Sin embargo, los lactobacilos comparten con los patógenos algunos de los mecanismos de adhesión. Las diferentes adhesinas identificadas en lactobacilos pueden clasificarse en función de su diana de unión, su localización en la superficie bacteriana o la forma en la que se han anclado a la misma. 


\section{INTRODUCCIÓN}

\subsection{Proteínas de unión a mucus:}

La renovación del mucus es relativamente rápida, lo que protege al hospedador de la colonización por microorganismos indeseables, puede también servir de hábitat para bacterias comensales como los lactobacilos (Velez, et al., 2007).

Aunque fracciones sacarídicas y ácidos lipoteicoicos podrían estar implicados en dicha unión, se propone que en la mayoría de los casos esté mediada por proteínas. Así, las adhesinas de mucus identificadas hasta la fecha en lactobacilos son de carácter proteico.

La mucus-binding protein (Mub) de Lactobacillus reuteri 1063, la adhesina específica de manosa tipo lectina (Msa) de $L$. plantarum WCFS1 y la Mub de L. acidophilus NCFM, presentan los dominios típicos de proteínas de superficie de bacterias Grampositivas (un péptido señal $\mathrm{N}$-terminal que determina su exportación y una secuencia conservada en $\mathrm{C}$-terminal reconocible por sortasas para su anclaje covalente al peptidoglicano de pared). Adicionalmente, tienen varias repeticiones de un dominio proteico de unión a mucus denominado MuB o MucBP (Mucin Binding Protein) presente repetido hasta 15 veces. La búsqueda en bases de datos de secuencias genomicas de lactobacilos de proteínas con dominios MuB revela que estas se encuentran exclusivamente en lactobacilos que poseen un hábitat gastrointestinal, lo que apoya la hipótesis de que estas proteínas juegan un papel importante en la adaptación de los lactobacilos a este nicho (Boekhorst, et al., 2006).

L. rhamnosus GG es una cepa que muestra adherencia a mucus y células epiteliales en cultivo 10 veces mayor que $L$. rhamnosus LC705. La comparación de sus genomas permitió identificar una isla génica con 3 genes codificantes de subunidades de pilus (spaCBA) con secuencia LPXTG y una sortasa dedicada al ensamblaje de pili.

En algunos patógenos Gram-positivos estos apéndices facilitan la adhesión a células del hospedador. En L. rhamnosus GG se confirmó la presencia en superficie de SpaC. 
El pre-tratamiento de las células con antituero anti-SpaC o bien el mutante deficiente en spaC presentaban una disminución estadísticamente significativa a mucus intestinal humano. Este podría ser uno de los factores que expliquen la persistencia de $L$. rhamnosus GG en el tracto gastrointestinal y la competencia por los sitios de unión con microorganismos patógenos.

También se ha especulado que podrían actuar como estímulos para el sistema inmune contribuyendo a las propiedades beneficiosas para la salud de esta cepa (Kankainen, et al., 2009). Hasta la fecha, éste es el primer ejemplo de la presencia de estas estructuras de adhesión en una cepa de lactobacilo e ilustra las diferentes adaptaciones de cepas específicas al tracto gastrointestinal.

\subsection{Proteínas de la capa de superficie (S-layer) como adhesinas:}

La capa $S$ es una malla proteica bidimensional presente en bastantes especies de Lactobacillus así como en otras bacterias y arqueas, que rodea la pared y se ancla no covalentemente a la misma. Puede suponer un escudo defensivo, que pasaría a ser considerado un factor de virulencia en el caso de proteger a un patógeno del sistema inmune del hospedador.

Suele resultar del ensamblaje de subunidades idénticas y presenta poros iguales entre sí distribuidos regularmente que suponen el $70 \%$ de la superficie, lo que podría servir como una criba. Las unidades de la capa $\mathrm{S}$ pueden unirse entre sí, al peptidoglicano y a los polímeros secundarios de pared.

La función biológica de muchas de estas proteínas resta por ser validada, salvo en el caso de SIp de L. helveticus R0052, las SIpA de Lactobacillus brevis ATCC 8287 y L. acidophilus NCFM, y CbsA de L. crispatus JCM 5810. Se ha caracterizado que estas proteínas median la adhesión a células epiteliales intestinales y a proteínas de la matriz extracelular, pudiendo prevenir la adhesión de bacterias patógenas a las mismas (Avall-Jaaskelainen \& Palva, 2005). 


\section{INTRODUCCIÓN}

De igual manera, se ha descrito que la proteína de la capa $S$ de $L$. acidophilus NCFM es un ligando para los receptores DC-SIGN presentes en la células dendríticas, y que su unión modula la producción de interleuquinas, por lo que estas proteínas, además de influenciar la adhesión, pueden ser componentes de los mecanismos de comunicación bacteria-célula epitelial (Konstantinov, et al., 2008).

\subsection{Proteínas que median la adhesión a la matriz extracelular:}

Las proteínas de la matriz extracelular podrían quedar expuestas en el caso de dañarse la mucosa (trauma, inflamación, infección) y conducir a una colonización por microorganismos patógenos. Los patógenos poseen un repertorio variado de adhesinas capaces de interaccionar con proteínas de la matriz extracelular que resultan vitales para los procesos de infección y diseminación por el organismo. Determinados lactobacilos pueden competir por estos sitios de unión con los patógenos, lo que supondría un beneficio para el hospedador.

\subsubsection{Unión a colágeno:}

Las proteínas de la capa S CbsA de Lactobacillus crispatus JCM 5810 y SIpA de L. brevis ATCC 8287 son ejemplos de proteínas de superficie capaces de unir colágeno.

Aleljung y colaboradores purificaron por afinidad dos proteínas de unión a colágeno de tipo I de 29 y 31 kDa (Collagen binding proteins (nBP) en L. reuteri NCIB 11951 usando la fracción de superficie de la bacteria y cromatografía en colágeno-sefarosa (Aleljung, et al., 1994).

La secuencia del gen cnb, que codifica la proteína de $29 \mathrm{kDa}$, presenta similitudes a la del dominio de unión de soluto de transportadores ABC bacterianos (Roos, et al., 1996).

Lactobacillus fermentum RC-14 libera al medio una proteína de $29 \mathrm{kDa}$ con capacidad de interferir con la adhesión del uropatógeno E. faecalis 1131. El extremo N-terminal tiene una identidad de secuencia del 100\% con la CnBP de L. reuteri NCIB 11951 (Heinemann, et al., 2000). 


\section{INTRODUCCIÓN}

\subsubsection{Unión a fibronectina:}

La proteína de la capa S SIpA de L. brevis ATCC 8287 anteriormente mencionada es capaz asimismo de unir fibronectina.

Buck y colaboradores identificaron una proteína de unión a fibronectina, FbpA, en L. acidophilus NCFM que contiene en $\mathrm{N}$ terminal el dominio de unión a fibronectina pfam05833. Este dominio en algunos patógenos ha sido descrito en proteínas que muestran unión a fibronectina o son necesarias para el proceso de infección, aunque su función real resulta todavía poco conocida. La inactivación de su gen produce una disminución aproximada del $76 \%$ en la capacidad de adhesión a células Caco-2 (Buck, et al., 2005).

\subsection{Proteínas moonlighting como factores de adhesión:}

Como se mencionó anteriormente, es bastante habitual la identificación en la superficie bacteriana de determinadas proteínas citoplásmicas pese a que éstas carecen de dominios de exportación y retención. En la superficie desempeñan una función alternativa a aquella con la que fueron inicialmente descritas.

La investigación llevada a cabo sobre todo con bacterias patógenas ha determinado que muchas de estas proteínas actúan como factores de virulencia mediando procesos de adhesión e invasión y, de hecho, muchas son antígenos prevalentes en diversas especies (Antikainen, et al., 2007, Cehovin, et al., 2010, Matta, et al., 2010, Tunio, et al., 2010).

Los lactobacilos y otras especies comensales del tracto gastrointestinal comparten con los patógenos algunas de estas características. Entre estas adhesinas atípicas podemos encontrarnos, por ejemplo, con factores de elongación del péptido durante la síntesis proteica, con proteínas de respuesta a estrés o con enzimas glicolíticas.

El factor de elongación Tu se localiza en la superficie de $L$. johnsonii NCC 533 (La1) y es uno de los factores responsables de la capacidad de dicha cepa de unirse a células Caco-2 diferenciadas. 


\section{INTRODUCCIÓN}

La obtención de una proteína recombinante con cola de histidinas permitió determinar su capacidad de unirse a células Caco2, HT-29 y a mucina purificada de la línea celular HT-29 MTX de forma dependiente del pH. Además, la importancia de la proteína en la unión de La1 quedó demostrada en estudios de competición entre células de la cepa y la proteína recombinante purificada (Granato, et al., 2004).También en $L$. johnsonii La1 se detectó la chaperona GroEL en superficie. Utilizando una forma recombinante de la misma se constató su capacidad de unir mucinas y células epiteliales, componentes de la mucosa, lo que sugirió su posible papel en la homeostasis gastrointestinal (Bergonzelli, et al., 2006).

El factor de elongación Tu (EF-Tu), la gliceraldehído-3-fosfato deshidrogenasa (GAPDH) y la triosa fosfato isomerasa de $L$. plantarum 423 están implicadas en la unión a células Caco-2 (Ramiah, et al., 2008).

La GAPDH de L. plantarum LA 318 se localiza en superficie y es capaz de unir mucina humana como demuestran los experimentos con la proteína purificada (Kinoshita, et al., 2008).

En un estudio sobre el perfil de las proteínas de superficie de cepas de L. plantarum con diferente capacidad de adhesión a mucus, se observó que, en la cepa más adherente, estaban sobreexpresadas en superficie las chaperonas GroES, GroEL y DnaK, así como EF-Tu y la enzima GAPDH. Esto sugiere su posible implicación en el proceso de adhesión y su uso como marcadores moleculares de dicha capacidad (Izquierdo, et al., 2009).

\subsection{Adhesión mediada por factores no proteicos:}

\subsection{1 Ácidos lipoteicoicos:}

Los ácidos lipoteicoicos constituyen la mayor aportación a la hidrofobicidad de superficie en función de las sustituciones con ésteres de D-alanina. Por tanto contribuirían principalmente a la adhesión inespecífica. 
En un trabajo del año 1999, Granato y colaboradores usaron anticuerpos monoclonales para determinar en qué estribaba la diferencia entre la cepa de L. johnsonii La1 y la de L. acidophilus La10, que hacía que la primera tuviera capacidad de adhesión a la línea Caco-2 mientras que la segunda no. El factor de adhesión identificado era no proteico: ácido lipoteicoico. Esta observación se confirmó al comprobar una inhibición dependiente de concentración de la adhesión de las células enteras a las Caco-2 al añadir ácido lipoteicoico purificado (Granato, et al., 1999).

\subsubsection{Exopolisacáridos:}

Al igual que los ácidos lipoteicoicos, los exopolisacáridos participan en interacciones inespecíficas con superficies bióticas o abióticas al contribuir a determinar las propiedades fisicoquímicas de superficie.

Pueden tanto estar directamente implicados en la adhesión, como tener un efecto indirecto al ser responsables de enmascarar otras adhesinas de superficie.

L. rhamnosus GG es una cepa que resiste bien las duras condiciones del tracto gastrointestinal, que es capaz de persistir más de una semana tras el cese de su administración en individuos adultos sanos, que se adhiere bien a cultivos celulares y a mucus in vitro y que puede formar biofilms en superficies no biológicas. El gen $w z b$ de L. rhamnosus GG codifica una fosfotirosina fosfatasa que regula la biosíntesis de un exopolisacárido y su tamaño. Usando la tecnología del ARN antisentido se observó una disminución en la formación de biofilms y capacidades adhesivas (Lebeer, et al., 2007).

Se identificó un cluster que codifica las enzimas y las proteínas reguladoras y transportadoras implicadas en la síntesis de exopolisacárido en L. rhamnosus GG. Al mutar el gen welE, que codifica una glicosil transferasa, la célula queda privada de los exopolisacáridos largos ricos en galactosa y aumenta su adherencia a mucus y células epiteliales, así como su capacidad de formación de biofilms. 


\section{INTRODUCCIÓN}

Esto podría deberse a la exposición en superficie de estructuras de tipo fimbria anteriormente enmascaradas por los exopolisacáridos (Lebeer, et al., 2009). 


\section{BIBLIOGRAFÍA}

Aleljung $\mathrm{P}$, Shen W, Rozalska B, Hellman $U$, Ljungh A \& Wadstrom $T$ (1994) Purification of collagenbinding proteins of Lactobacillus reuteri NCIB 11951. Curr Microbiol 28: 231-236.

Anderson RC, Cookson AL, McNabb WC, Kelly WJ \& Roy NC (2010) Lactobacillus plantarum DSM 2648 is a potential probiotic that enhances intestinal barrier function. FEMS Microbiol Lett 309: 184-192.

Antikainen J, Kuparinen V, Lahteenmaki K \& Korhonen TK (2007) Enolases from Gram-positive bacterial pathogens and commensal lactobacilli share functional similarity in virulence-associated traits. FEMS Immunol Med Microbiol 51: 526-534.

Arumugam M, Raes J, Pelletier E, et al. (2011) Enterotypes of the human gut microbiome. Nature 473: 174-180.

Aumailley M \& Gayraud B (1998) Structure and biological activity of the extracellular matrix. $J \mathrm{Mol}$ Med 76: 253-265.

Avall-Jaaskelainen S \& Palva A (2005) Lactobacillus surface layers and their applications. FEMS Microbiol Rev 29: 511-529.

Basson MD (2003) Invited research review: Cell-matrix interactions in the gut epithelium. Surgery 133: $263-267$

Bath K, Roos S, Wall T \& Jonsson H (2005) The cell surface of Lactobacillus reuteri ATCC 55730 highlighted by identification of 126 extracellular proteins from the genome sequence. FEMS Microbiol Lett 253: 75-82.

Bauerl C, Perez-Martinez G, Yan F, Polk DB \& Monedero V (2010) Functional Analysis of the p40 and p75 Proteins from Lactobacillus casei BL23. J Mol Microbiol Biotechnol 19: 231-241.

Bergonzelli GE, Granato D, Pridmore RD, Marvin-Guy LF, Donnicola D \& Corthesy-Theulaz IE (2006) GroEL of Lactobacillus johnsonii La1 (NCC 533) is cell surface associated: potential role in interactions with the host and the gastric pathogen Helicobacter pylori. Infect Immun 74: 425-434.

Boekhorst J, Helmer Q, Kleerebezem M \& Siezen RJ (2006) Comparative analysis of proteins with a mucus-binding domain found exclusively in lactic acid bacteria. Microbiology 152: 273-280.

Bosscher D, Breynaert A, Pieters L \& Hermans N (2009) Food-based strategies to modulate the composition of the intestinal microbiota and their associated health effects. J Physiol Pharmacol 60 Suppl 6: 5-11.

Bourlioux P, Koletzko B, Guarner F \& Braesco V (2003) The intestine and its microflora are partners for the protection of the host: report on the Danone Symposium "The Intelligent Intestine," held in Paris, June 14, 2002. Am J Clin Nutr 78: 675683.

Bouzaine T, Dauphin RD, Thonart $P$, Urdaci MC \& Hamdi M (2005) Adherence and colonization 


\section{INTRODUCCIÓN}

properties of Lactobacillus rhamnosus TB1, a broiler chicken isolate. Lett Appl Microbiol 40: 391-396.

Buck BL, Altermann E, Svingerud T \& Klaenhammer TR (2005) Functional analysis of putative adhesion factors in Lactobacillus acidophilus NCFM. Appl Environ Microbiol 71: 8344-8351.

Caballero-Franco C, Keller K, De Simone C \& Chadee $K$ (2007) The VSL\#3 probiotic formula induces mucin gene expression and secretion in colonic epithelial cells. Am J Physiol Gastrointest Liver Physiol 292: G315-322.

Cabanes D, Dehoux P, Dussurget O, Frangeul L \& Cossart P (2002) Surface proteins and the pathogenic potential of Listeria monocytogenes. Trends Microbiol 10: 238-245.

Cai H, Thompson R, Budinich MF, Broadbent JR \& Steele JL (2009) Genome sequence and comparative genome analysis of Lactobacillus casei: insights into their niche-associated evolution. Genome Biol Evol 1: 239-257.

Candela M, Perna F, Carnevali P, et al. (2008) Interaction of probiotic Lactobacillus and Bifidobacterium strains with human intestinal epithelial cells: adhesion properties, competition against enteropathogens and modulation of IL-8 production. Int J Food Microbiol 125: 286292.

Cehovin A, Coates AR, Hu Y, et al. (2010) Comparison of the moonlighting actions of the two highly homologous chaperonin 60 proteins of Mycobacterium tuberculosis. Infect Immun $\mathbf{7 8}$ 3196-3206.

Collado MC, Meriluoto J \& Salminen S (2007) Role of commercial probiotic strains against human pathogen adhesion to intestinal mucus. Lett Appl Microbiol 45 454-460.

Chassard C, Scott KP, Marquet $\mathrm{P}$, et al. (2008) Assessment of metabolic diversity within the intestinal microbiota from healthy humans using combined molecular and cultural approaches. FEMS Microbiol Ecol 66: 496-504.

Chen I \& Dubnau D (2004) DNA uptake during bacterial transformation. Nat Rev Microbiol 2: 241-249.

de Jong A, van Hijum SA, Bijlsma JJ, Kok J \& Kuipers OP (2006) BAGEL: a web-based bacteriocin genome mining tool. Nucleic Acids Res 34: W273-279.

de Leeuw E, Li X \& Lu W (2006) Binding characteristics of the Lactobacillus brevis ATCC 8287 surface layer to extracellular matrix proteins. FEMS Microbiol Lett 260: 210-215.

de Moreno de LeBlanc A, Dogi CA, Galdeano CM, Carmuega E, Weill $R$ \& Perdigon G (2008) Effect of the administration of a fermented milk containing Lactobacillus casei DN-114001 on intestinal microbiota and gut associated immune cells of nursing mice and after weaning until immune maturity. BMC Immunol 9: 27.

de Moreno de LeBlanc A, Chaves $S$, Carmuega E, Weill R, Antoine J \& Perdigon G (2008) Effect of longterm continuous consumption of fermented milk containing 
probiotic bacteria on mucosal immunity and the activity of peritoneal macrophages. Immunobiology 213: 97-108.

Deepika G \& Charalampopoulos D (2010) Surface and adhesion properties of lactobacilli. Adv Appl Microbiol 70: 127-152.

Denou E, Pridmore RD, Berger B, Panoff $\mathrm{JM}$, Arigoni $\mathrm{F} \&$ Brussow $\mathrm{H}$ (2008) Identification of genes associated with the long-gutpersistence phenotype of the probiotic Lactobacillus johnsonii strain NCC533 using a combination of genomics and transcriptome analysis. J Bacteriol 190: 3161-3168.

Desvaux M, Dumas E, Chafsey I \& Hebraud M (2006) Protein cell surface display in Gram-positive bacteria: from single protein to macromolecular protein structure. FEMS Microbiol Lett 256: 1-15.

Dicks LM, Du Plessis EM, Dellaglio F \& Lauer E (1996) Reclassification of Lactobacillus casei subsp. casei ATCC 393 and Lactobacillus rhamnosus ATCC 15820 as Lactobacillus zeae nom. rev., designation of ATCC 334 as the neotype of $L$. casei subsp. casei, and rejection of the name Lactobacillus paracasei. Int J Syst Bacteriol 46: 337-340.

Dramsi S, Trieu-Cuot P \& Bierne H (2005) Sorting sortases: a nomenclature proposal for the various sortases of Gram-positive bacteria. Res Microbiol 156: 289-297.

Dramsi S, Magnet S, Davison S \& Arthur M (2008) Covalent attachment of proteins to peptidoglycan. FEMS Microbiol Rev 32: 307-320.
Duncan SH, Louis P \& Flint HJ (2007) Cultivable bacterial diversity from the human colon. Lett Appl Microbiol 44: 343-350.

Durant JA, Corrier DE \& Ricke SC (2000) Short-chain volatile fatty acids modulate the expression of the hilA and invF genes of Salmonella typhimurium. J Food Prot 63: 573-578.

Eldholm V, Johnsborg O, Straume $D$ Ohnstad HS, Berg KH, Hermoso JA \& Havarstein LS (2010) Pneumococcal CbpD is a murein hydrolase that requires a dual cell envelope binding specificity to kill target cells during fratricide. Mol Microbiol 76: 905917.

Food and Agriculture Organization of the United Nations. \& World Health Organization. (2006) Probiotics in food : health and nutritional properties and guidelines for evaluation. Food and Agriculture Organization of the United Nations : World Health Organization, Rome.

Galdeano CM \& Perdigon G (2006) The probiotic bacterium Lactobacillus casei induces activation of the gut mucosal immune system through innate immunity. Clin Vaccine Immunol 13: 219-226.

Gianotti L, Morelli L, Galbiati F, et al. (2010) A randomized doubleblind trial on perioperative administration of probiotics in colorectal cancer patients. World J Gastroenterol 16: 167-175.

Gibson GR \& Roberfroid MB (1995) Dietary modulation of the human colonic microbiota: introducing the concept of prebiotics. J Nutr 125: 14011412. 


\section{INTRODUCCIÓN}

Gill SR, Pop M, Deboy RT, et al. (2006) Metagenomic analysis of the human distal gut microbiome. Science 312: 1355-1359.

Gillor O, Etzion A \& Riley MA (2008) The dual role of bacteriocins as antiand probiotics. Appl Microbiol Biotechnol 81: 591-606.

Granato D, Bergonzelli GE, Pridmore RD Marvin L, Rouvet M \& CorthesyTheulaz IE (2004) Cell surfaceassociated elongation factor Tu mediates the attachment of Lactobacillus johnsonii NCC533 (La1) to human intestinal cells and mucins. Infect Immun 72: 2160-2169.

Granato D, Perotti F, Masserey I, Rouvet $M$, Golliard $M$, Servin A \& Brassart D (1999) Cell surfaceassociated lipoteichoic acid acts as an adhesion factor for attachment of Lactobacillus johnsonii La1 to human enterocyte-like Caco-2 cells. Appl Environ Microbiol 65: 1071-1077.

Hamady M \& Knight R (2009) Microbial community profiling for human microbiome projects: Tools, techniques, and challenges. Genome Res 19: 1141-1152.

Havarstein LS, Diep DB \& Nes IF (1995) A family of bacteriocin $A B C$ transporters carry out proteolytic processing of their substrates concomitant with export. Mol Microbiol 16: 229240.

Heilmann C, Hartleib J, Hussain MS \& Peters G (2005) The multifunctional Staphylococcus aureus autolysin aaa mediates adherence to immobilized fibrinogen and fibronectin. Infect Immun 73: 4793-4802.
Heinemann C, van Hylckama Vlieg JE, Janssen DB, Busscher $\mathrm{HJ}$, van der Mei HC \& Reid G (2000) Purification and characterization of a surface-binding protein from Lactobacillus fermentum RC-14 that inhibits adhesion of Enterococcus faecalis 1131. FEMS Microbiol Lett 190: 177180.

Hijova E \& Chmelarova A (2007) Short chain fatty acids and colonic health. Bratis/ Lek Listy 108: 354358.

Horie $M$, Ishiyama A, Fujihira-Ueki $Y$, Sillanpaa J, Korhonen TK \& Toba $T$ (2002) Inhibition of the adherence of Escherichia coli strains to basement membrane by Lactobacillus crispatus expressing an S-layer. J Appl Microbiol 92: 396-403.

Hsiao WW, Metz C, Singh DP \& Roth J (2008) The microbes of the intestine: an introduction to their metabolic and signaling capabilities. Endocrinol Metab Clin North Am 37: 857-871.

Hulmes DJ (2002) Building collagen molecules, fibrils, and suprafibrillar structures. J Struct Biol 137: 2-10.

Humann J \& Lenz LL (2009) Bacterial peptidoglycan degrading enzymes and their impact on host muropeptide detection. J Innate Immun 1: 88-97.

Hurmalainen V, Edelman S, Antikainen J, Baumann M, Lahteenmaki $\mathrm{K}$ \& Korhonen TK (2007) Extracellular proteins of Lactobacillus crispatus enhance activation of human plasminogen. Microbiology 153: 1112-1122. 
Izquierdo E, Horvatovich P, Marchioni E, Aoude-Werner D, Sanz $Y$ \& Ennahar S (2009) 2-DE and MS analysis of key proteins in the adhesion of Lactobacillus plantarum, a first step toward early selection of probiotics based on bacterial biomarkers. Electrophoresis 30: 949-956.

Jankovic I, Sybesma W, Phothirath P, Ananta E \& Mercenier A (2010) Application of probiotics in food products--challenges and new approaches. Curr Opin Biotechnol 21: 175-181.

Kang W \& Kudsk KA (2007) Is there evidence that the gut contributes to mucosal immunity in humans? JPEN J Parenter Enteral Nutr 31: 246-258.

Kankainen M, Paulin L, Tynkkynen S, et al. (2009) Comparative genomic analysis of Lactobacillus rhamnosus GG reveals pili containing a human- mucus binding protein. Proc Natl Acad Sci U S A 106: 17193-17198.

Karczewski J, Troost FJ, Konings I, Dekker J, Kleerebezem M, Brummer RJ \& Wells JM (2010) Regulation of human epithelial tight junction proteins by Lactobacillus plantarum in vivo and protective effects on the epithelial barrier. Am J Physiol Gastrointest Liver Physiol 298: G851-859.

Kinoshita $\mathrm{H}$, Uchida $\mathrm{H}$, Kawai $\mathrm{Y}$, et al. (2008) Cell surface Lactobacillus plantarum LA 318 glyceraldehyde-3-phosphate dehydrogenase

(GAPDH) adheres to human colonic mucin. J Appl Microbiol 104: 1667-1674.

Kleerebezem M \& Vaughan EE (2009) Probiotic and gut lactobacilli and bifidobacteria: molecular approaches to study diversity and activity. Annu Rev Microbiol 63: 269-290.

Kleerebezem M, Hols $P$, Bernard E, Rolain $T$, Zhou M, Siezen RJ \& Bron PA (2010) The extracellular biology of the lactobacilli. FEMS Microbiol Rev 34: 199-230.

Konstantinov SR, Smidt $\mathrm{H}$, de Vos WM, et al. (2008) S layer protein A of Lactobacillus acidophilus NCFM regulates immature dendritic cell and $\mathrm{T}$ cell functions. Proc Natl Acad Sci U S A 105: 1947419479.

Lara-Villoslada F, Sierra S, Boza J, Xaus J \& Olivares M (2007) [Beneficial effects of consumption of a dairy product containing two probiotic strains, Lactobacillus coryniformis CECT5711 and Lactobacillus gasseri CECT5714 in healthy children]. Nutr Hosp 22: 496-502.

Le Leu RK, Hu Y, Brown IL, Woodman RJ \& Young GP (2010) Synbiotic intervention of Bifidobacterium lactis and resistant starch protects against colorectal cancer development in rats. Carcinogenesis 31: 246-251.

Lebeer S, Vanderleyden J \& De Keersmaecker SC (2008) Genes and molecules of lactobacilli supporting probiotic action. Microbiol Mol Biol Rev 72: 728764, Table of Contents.

Lebeer S, Verhoeven TL, Perea Velez M, Vanderleyden J \& De Keersmaecker SC (2007) Impact of environmental and genetic factors on biofilm formation by the probiotic strain Lactobacillus rhamnosus GG. Appl Environ Microbiol 73: 6768-6775. 


\section{INTRODUCCIÓN}

Lebeer S, Verhoeven TL, Francius G, et al. (2009) Identification of a Gene Cluster for the Biosynthesis of a Long, Galactose-Rich Exopolysaccharide Lactobacillus rhamnosus GG and Functional Analysis of the Priming Glycosyltransferase. Appl Environ Microbiol 75: 35543563.

Lee YK, Puong KY, Ouwehand AC \& Salminen S (2003) Displacement of bacterial pathogens from mucus and Caco- 2 cell surface by lactobacilli. J Med Microbiol 52: 925-930.

Leser TD \& Molbak L (2009) Better living through microbial action: the benefits of the mammalian gastrointestinal microbiota on the host. Environ Microbiol 11: 2194-2206.

Lu JZ, Fujiwara T, Komatsuzawa H, Sugai M \& Sakon J (2006) Cell walltargeting domain of glycylglycine endopeptidase distinguishes among peptidoglycan crossbridges. J Biol Chem 281: 549558.

Lucena S, Arocha Pinango CL \& Guerrero B (2007) [Fibronectin. Structure and functions associated to hemostasis. Review]. Invest Clin 48: 249-262.

Mack DR, Michail S, Wei S, McDougall L \& Hollingsworth MA (1999) Probiotics inhibit enteropathogenic $E$. coli adherence in vitro by inducing intestinal mucin gene expression. Am J Physiol 276: G941-950.

Mack DR, Ahrne S, Hyde L, Wei S \& Hollingsworth MA (2003) Extracellular MUC3 mucin secretion follows adherence of
Lactobacillus strains to intestinal epithelial cells in vitro. Gut 52: 827-833.

Mai V \& Draganov PV (2009) Recent advances and remaining gaps in our knowledge of associations between gut microbiota and human health. World J Gastroenterol 15: 81-85.

Manning TS \& Gibson GR (2004) Microbial-gut interactions in health and disease. Prebiotics. Best Pract Res Clin Gastroenterol 18: 287-298.

Marchesi JR (2010) Prokaryotic and eukaryotic diversity of the human gut. Adv Appl Microbiol 72: 43-62.

Maresso AW \& Schneewind O (2008) Sortase as a target of antiinfective therapy. Pharmacol Rev 60: 128-141.

Marraffini LA \& Schneewind O (2005) Anchor structure of staphylococcal surface proteins. V. Anchor structure of the sortase B substrate IsdC. I Biol Chem 280: 16263-16271.

Marraffini LA \& Schneewind O (2006) Targeting proteins to the cell wall of sporulating Bacillus anthracis. Mol Microbiol 62: 1402-1417.

Marraffini LA, Dedent AC \& Schneewind O (2006) Sortases and the art of anchoring proteins to the envelopes of gram-positive bacteria. Microbiol Mol Biol Rev 70: 192-221.

Martins AK, Martins FS, Gomes DA, et al (2010) Evaluation of in vitro antagonism and of in vivo immune modulation and 


\section{INTRODUCCIÓN}

protection against pathogenic experimental challenge of two probiotic strains of Bifidobacterium animalis var. lactis. Arch Microbiol.

Martins FS, Silva AA, Vieira AT, Barbosa $\mathrm{FH}$, Arantes RM, Teixeira MM \& Nicoli JR (2009) Comparative study of Bifidobacterium animalis, Escherichia coli, Lactobacillus casei and Saccharomyces boulardii probiotic properties. Arch Microbiol 191: 623-630.

Matta SK, Agarwal S \& Bhatnagar R (2010) Surface localized and extracellular Glyceraldehyde-3phosphate dehydrogenase of Bacillus anthracis is a plasminogen binding protein. Biochim Biophys Acta 1804: 2111-2120.

Mattar AF, Teitelbaum DH, Drongowski RA, Yongyi $F$, Harmon CM \& Coran AG (2002) Probiotics upregulate MUC-2 mucin gene expression in a Caco-2 cellculture model. Pediatr Surg Int 18: $586-590$

Maze A, Boel G, Zuniga M, et al. (2010) Complete genome sequence of the probiotic Lactobacillus casei strain BL23. J Bacteriol 192: 2647-2648.

Mennigen R, Nolte K, Rijcken E, Utech M, Loeffler B, Senninger N \& Bruewer M (2009) Probiotic mixture VSL\#3 protects the epithelial barrier by maintaining tight junction protein expression and preventing apoptosis in a murine model of colitis. Am J Physiol Gastrointest Liver Physiol 296: G1140-1149.

Millette M, Luquet FM \& Lacroix M (2007) In vitro growth control of selected pathogens by Lactobacillus acidophilus- and Lactobacillus casei-fermented milk. Lett App/ Microbiol 44: 314319.

Moorthy G, Murali MR \& Devaraj SN (2009) Lactobacilli facilitate maintenance of intestinal membrane integrity during Shigella dysenteriae 1 infection in rats. Nutrition 25: 350-358.

Moschioni M, Pansegrau W \& Barocchi MA (2010) Adhesion determinants of the Streptococcus species. Microb Biotechnol 3: 370-388.

O'Hara AM \& Shanahan F (2006) The gut flora as a forgotten organ. EMBO Rep 7: 688-693.

Ohara T, Yoshino K \& Kitajima M (2009) [Pre- and probiotics increase host-cell immunological competence, improve bowel movement, and prevent the onset of colon cancer--an analysis based on movements of intestinal microbiota]. Rinsho Byori 57: 533-541.

Ohland CL \& Macnaughton WK (2010) Probiotic bacteria and intestinal epithelial barrier function. $\mathrm{Am} J$ Physiol Gastrointest Liver Physiol 298: G807-819.

Oozeer R, Furet JP, Goupil-Feuillerat N, Anba J, Mengaud J \& Corthier G (2005) Differential activities of four Lactobacillus casei promoters during bacterial transit through the gastrointestinal tracts of humanmicrobiota-associated mice. Appl Environ Microbiol 71: 1356-1363.

Ostad SN, Salarian AA, Ghahramani $\mathrm{MH}_{\text {, }}$ Fazeli MR, Samadi N \& Jamalifar $\mathrm{H}$ (2009) Live and heat- 


\section{INTRODUCCIÓN}

inactivated lactobacilli from feces inhibit Salmonella typhi and Escherichia coli adherence to Caco-2 cells. Folia Microbiol (Praha) 54: 157-160.

Otte JM \& Podolsky DK (2004) Functional modulation of enterocytes by gram-positive and gram-negative microorganisms. Am J Physiol Gastrointest Liver Physiol 286: G613-626.

Ouwehand AC, Tuomola EM, Tolkko S \& Salminen S (2001) Assessment of adhesion properties of novel probiotic strains to human intestinal mucus. Int $J$ Food Microbiol 64: 119-126.

Ouwehand AC, Salminen S, Roberts PJ, Ovaska J \& Salminen E (2003) Disease-dependent adhesion of lactic acid bacteria to the human intestinal mucosa. Clin Diagn Lab Immunol 10: 643-646.

Ouwehand AC, Salminen S, Tolkko S, Roberts P, Ovaska J \& Salminen E (2002) Resected human colonic tissue: new model for characterizing adhesion of lactic acid bacteria. Clin Diagn Lab Immunol 9: 184-186.

Palmer C, Bik EM, DiGiulio DB, Relman DA \& Brown PO (2007) Development of the human infant intestinal microbiota. PLOS Biol 5: e177.

Palumbo E, Deghorain M, Cocconcelli PS, et al. (2006) D-alanyl ester depletion of teichoic acids in Lactobacillus plantarum results in a major modification of lipoteichoic acid composition and cell wall perforations at the septum mediated by the Acm 2 autolysin. J Bacteriol 188: 37093715.
Perea Velez M, Verhoeven TL, Draing C, et al. (2007) Functional analysis of D-alanylation of lipoteichoic acid in the probiotic strain Lactobacillus rhamnosus GG. Appl Environ Microbiol 73: 35953604.

Pereira M \& Simpson-Haidaris PJ (2001) Fibrinogen modulates gene expression in wounded fibroblasts. Ann $N$ Y Acad Sci 936: 438-443.

Presser KA, Ratkowsky DA \& Ross T (1997) Modelling the growth rate of Escherichia coli as a function of $\mathrm{pH}$ and lactic acid concentration. Appl Environ Microbiol 63: 23552360.

Ramiah K, van Reenen CA \& Dicks LM (2008) Surface-bound proteins of Lactobacillus plantarum 423 that contribute to adhesion of Caco-2 cells and their role in competitive exclusion and displacement of Clostridium sporogenes and Enterococcus faecalis. Res Microbiol 159: 470475.

Ramiro-Puig E, Perez-Cano FJ, Castellote C, Franch A \& Castell M (2008) The bowel: a key component of the immune system. Rev Esp Enferm Dig 100: 29-34.

Resta-Lenert S \& Barrett KE (2003) Live probiotics protect intestinal epithelial cells from the effects of infection with enteroinvasive Escherichia coli (EIEC). Gut 52: 988-997.

Roos S, Aleljung P, Robert N, Lee B, Wadstrom $T$, Lindberg $M$ \& Jonsson $H$ (1996) A collagen binding protein from Lactobacillus reuteri is part of an $\mathrm{ABC}$ transporter system? FEMS Microbiol Lett 144: 33-38. 
Salminen S, Bouley C, Boutron-Ruault MC, et al. (1998) Functional food science and gastrointestinal physiology and function. $\mathrm{Br} J$ Nutr 80 Suppl 1: S147-171.

Sanchez B, Bressollier P \& Urdaci MC (2008) Exported proteins in probiotic bacteria: adhesion to intestinal surfaces, host immunomodulation and molecular cross-talking with the host. FEMS Immunol Med Microbiol 54: 1-17.

Schaible UE \& Kaufmann SH (2005) A nutritive view on the hostpathogen interplay. Trends Microbiol 13: 373-380.

Scharlau D, Borowicki A, Habermann N, et al. (2009) Mechanisms of primary cancer prevention by butyrate and other products formed during gut floramediated fermentation of dietary fibre. Mutat Res 682: 3953.

Schlee M, Wehkamp J, Altenhoefer A, Oelschlaeger TA, Stange EF \& Fellermann K (2007) Induction of human beta-defensin 2 by the probiotic Escherichia coli Nissle 1917 is mediated through flagellin. Infect Immun 75: 23992407.

Schlee M, Harder J, Koten B, Stange EF, Wehkamp J \& Fellermann K (2008) Probiotic lactobacilli and VSL\#3 induce enterocyte betadefensin 2. Clin Exp Immunol 151: 528-535.

Schultz M, Gottl C, Young RJ, Iwen P \& Vanderhoof JA (2004) Administration of oral probiotic bacteria to pregnant women causes temporary infantile colonization. J Pediatr Gastroenterol Nutr 38: 293-297.
Sekirov I, Russell SL, Antunes LC \& Finlay BB (2010) Gut microbiota in health and disease. Physiol Rev 90: 859-904.

Sharma R, Young C \& Neu J (2010) Molecular modulation of intestinal epithelial barrier: contribution of microbiota. J Biomed Biotechnol 2010: 305879.

Shen L (2009) Functional morphology of the gastrointestinal tract. Curr Top Microbiol Immunol 337: 135.

Sherman PM, Ossa JC \& Johnson-Henry K (2009) Unraveling mechanisms of action of probiotics. Nutr Clin Pract 24: 10-14.

Siezen R, Boekhorst J, Muscariello L, Molenaar D, Renckens B \& Kleerebezem M (2006) Lactobacillus plantarum gene clusters encoding putative cellsurface protein complexes for carbohydrate utilization are conserved in specific grampositive bacteria. BMC Genomics 7: 126.

Simon-Assmann $P$, Lefebvre O, BellissentWaydelich A, Olsen J, OrianRousseau V \& De Arcangelis A (1998) The laminins: role in intestinal morphogenesis and differentiation. Ann N Y Acad Sci 859: 46-64.

Smith K, McCoy KD \& Macpherson AJ (2007) Use of axenic animals in studying the adaptation of mammals to their commensal intestinal microbiota. Semin Immunol 19: 59-69.

Steen A, Buist G, Leenhouts KJ, et al. (2003) Cell wall attachment of a widely distributed peptidoglycan binding domain is hindered by 


\section{INTRODUCCIÓN}

cell wall constituents. I Biol Chem 278: 23874-23881.

Styriak I \& Nemcova R (2003) Lectin-like binding of lactobacilli considered for their use in probiotical preparations for animal use. Berl Munch Tierarztl Wochenschr 116: 96-101

Sutcliffe IC \& Harrington DJ (2002) Pattern searches for the identification of putative lipoprotein genes in Gram-positive bacterial genomes. Microbiology 148: 2065-2077.

Tap J, Mondot S, Levenez F, et al. (2009) Towards the human intestinal microbiota phylogenetic core. Environ Microbiol 11: 2574-2584.

Ton-That H \& Schneewind O (2003) Assembly of pili on the surface of Corynebacterium diphtheriae. Mol Microbiol 50: 1429-1438.

Tunio SA, Oldfield NJ, Berry A, Ala'Aldeen DA, Wooldridge KG \& Turner DP (2010) The moonlighting protein fructose-1, 6-bisphosphate aldolase of Neisseria meningitidis: surface localization and role in host cell adhesion. Mol Microbiol 76: 605-615.

Ukena SN, Singh A, Dringenberg U, et al. (2007) Probiotic Escherichia coli Nissle 1917 inhibits leaky gut by enhancing mucosal integrity. PLoS One 2: e1308.

van Wely KH, Swaving J, Freudl R \& Driessen AJ (2001) Translocation of proteins across the cell envelope of Gram-positive bacteria. FEMS Microbiol Rev 25: 437-454.

Velez MP, De Keersmaecker SC \& Vanderleyden J (2007)
Adherence factors of Lactobacillus in the human gastrointestinal tract. FEMS Microbiol Lett 276: 140-148.

Vesterlund S, Paltta J, Karp M \& Ouwehand AC (2005) Adhesion of bacteria to resected human colonic tissue: quantitative analysis of bacterial adhesion and viability. Res Microbiol 156: 238-244.

Vesterlund S, Karp M, Salminen S \& Ouwehand AC (2006) Staphylococcus aureus adheres to human intestinal mucus but can be displaced by certain lactic acid bacteria. Microbiology 152 1819-1826

Waligora $\mathrm{AJ}$, Hennequin $\mathrm{C}$, Mullany $\mathrm{P}$, Bourlioux $P$, Collignon A \& Karjalainen $\quad T \quad$ (2001) Characterization of a cell surface protein of Clostridium difficile with adhesive properties. Infect Immun 69: 2144-2153.

Walter J, Loach DM, Alqumber M, Rockel C, Hermann C, Pfitzenmaier M \& Tannock GW (2007) D-alanyl ester depletion of teichoic acids in Lactobacillus reuteri 100-23 results in impaired colonization of the mouse gastrointestinal tract. Environ Microbiol 9: 17501760.

Wang IN, Smith DL \& Young R (2000) Holins: the protein clocks of bacteriophage infections. Annu Rev Microbiol 54: 799-825.

Wine E, Gareau MG, Johnson-Henry K \& Sherman PM (2009) Strainspecific probiotic (Lactobacillus helveticus) inhibition of Campylobacter jejuni invasion of human intestinal epithelial cells. FEMS Microbiol Lett 300: 146152. 


\section{INTRODUCCIÓN}

Wren BW (1991) A family of clostridial and streptococcal ligand-binding proteins with conserved Cterminal repeat sequences. $\mathrm{Mol}$ Microbiol 5: 797-803.

Yan F, Cao H, Cover TL, Whitehead R, Washington $\mathrm{MK}$ \& Polk DB (2007) Soluble proteins produced by probiotic bacteria regulate intestinal epithelial cell survival and growth. Gastroenterology 132: 562-575. 


\section{OBJETIVOS}

Cepas de la especie Lactobacillus casei son capaces de persistir en el tracto gastrointestinal y poseen un reconocido carácter probiótico. El Laboratorio de Bacterias Lácticas y Probióticos del IATA ha realizado numerosos estudios básicos y aplicados sobre la fisiología y genética de $L$. casei usando como modelo la cepa $L$. casei BL23, cuyo genoma ha sido recientemente secuenciado. En los últimos años el laboratorio se ha interesado en el estudio de los mecanismos que median la interacción probiótico/huésped y que condicionan sus efectos beneficiosos. En este contexto y debido a la importancia que la adhesión de los probióticos a componentes de la mucosa intestinal posee sobre factores clave como la persistencia, exclusión de patógenos o el mantenimiento de la homeostasis intestinal, en el presente trabajo se planteó como objetivo esclarecer los mecanismos de adhesión presentes en $L$. casei, particularmente en la cepa $L$. casei BL23. La consecución de este objetivo general se llevó a cabo mediante el planteamiento de tres objetivos específicos:

1.-Evaluación de la capacidad de adhesión a componentes de la matriz extracelular de cepas de $L$. casei provenientes de diferentes orígenes.

2.-Aplicación de diferentes técnicas para la identificación y caracterización de proteínas implicadas en la adhesión en $L$. casei.

3.-Estudio de la contribución a la adhesión de las proteínas de L. casei unidas covalentemente a la superficie mediante mecanismos dependientes de sortasas. 
CAPÍTULO 1 
CAPÍTULO 1

CAPÍTULO 1 
CAPÍTULO 1 


\section{CAPÍTULO 1}

\section{Adhesion properties of Lactobacillus casei strains to resected intestinal fragments and components of the extracellular matrix.}

Diego Muñoz-Provencio ${ }^{a}$, Marta Llopis ${ }^{b}$, María Antolín ${ }^{b}$, Inés de Torres ${ }^{c}$, Francisco Guarner ${ }^{b}$, Gaspar Pérez-Martínez ${ }^{a}$ and Vicente Monedero ${ }^{a}$.

aBiotechnology Department. Instituto de Agroquímica y Tecnología de Alimentos-CSIC. P.O. Box 73, 46100 Burjassot, Valencia, Spain.

${ }^{b}$ Digestive System Research Unit, University Hospital Vall d'Hebron, Centro de Investigación Biomédica en Red de Enfermedades Hepáticas y Digestivas (Ciberehd).

'Department of Pathological Anatomy, University Hospital Vall d'Hebron, Paseo Vall d'Hebron 129, 08035 Barcelona, Spain.

Published in Archives of Microbiology (2009) 191(2): 153-161 


\section{CAPÍTULO 1}

\section{ABSTRACT}

Adhesion to intestinal epithelium is an outcome property for the selection of probiotic lactic acid bacteria strains. We have analyzed the adhesion properties of a collection of Lactobacillus casei strains from different origins, ranging from cheese isolates to commercial probiotics. Analysis of the surface characteristics of the strains by measuring adhesion to solvents (MATS test) showed that most of the strains have a basic and hydrophobic surface.

The strains were able to bind ex vivo to human colon fragments at different levels and, in most cases, this adhesion correlated with the ability to in vitro binding of mucin. Attachment to this later substrate was not enhanced by growing the cells in the presence of mucin and was independent of proteinaceous factors. On the contrary, adhesion to other extracellular matrix components, such as collagen, fibronectin, or fibrinogen was partially or totally dependent on the presence of surface proteins.

These results show that most of $L$. casei strains have in their surfaces factors that promote binding to intestinal epithelium, however, no clear correlation appears to exist between the origin of the strains and their adhesion capacities.

Keywords: Lactobacillus casei, probiotic, extracellular matrix, adhesion 


\section{INTRODUCTION}

Lactic acid bacteria (LAB) are commonly used as probiotic organisms which aid to maintain a balanced intestinal microbiota, excluding pathogens and helping to keep the gut homeostasis by influencing the mucosal immune system.

Among several factors, adhesion to intestinal epithelium is one of the desirable characteristics for a potentially successful probiotic as it will assure the colonization of mucosal surfaces, at least transiently, thus interfering with pathogen binding and permitting an efficient interaction with the immune system cells. However, some authors have argued that attachment properties of $L A B$ are risk factors that might indicate their pathogenic potential. Therefore, a careful evaluation of these traits needs to be performed (Vesterlund, et al., 2007).

Adhesion mechanisms to host mucosa have been widely characterized in bacterial pathogens and, although it is believed that LAB might share some of these mechanisms, the adhesion process is less well known in this group of organisms (Velez, et al., 2007). Adhesive properties depend on a variety of factors, including nonspecific adhesion determined by electrostatic or hydrophobic forces and specific binding dependent on particular molecules.

To asses the adhesive capacity of $L A B$, several models have been developed. These include binding to tissue culture cells (Tuomola \& Salminen, 1998), intestinal mucus (Ouwehand, et al., 2001), extracellular matrix (ECM) proteins (Lorca, et al., 2002, Styriak, et al., 2003, de Leeuw, et al., 2006) and resected colonic tissue (Ouwehand, et al., 2002, Vesterlund, et al., 2005). Although none of these models reflect the complex interactions occurring in the mucosal layer of the digestive tract, they represent a fast method for the screening of strains and in most cases a good correlation is found between them.

Lactobacillus casei is a widely used species in the dairy industry and it is a normal constituent of the intestinal microbiota of healthy individuals. 


\section{CAPÍTULO 1}

This species has attracted intense interest as a probiotic and some strains are included in many commercial food products. L. casei can persist in the intestine and it can be found in the faeces for several days after the end of oral administration in humans (Oozeer, et al., 2006), furthermore, it has been demonstrated that $L$. casei can initiate protein synthesis during its pass through the digestive tract in animal models (Oozeer, et al., 2002).

With the aim of analyzing how the origin of a particular strain can influence its binding abilities to host mucosa, in this study we assessed the surface and adhesion characteristics of a collection of $L$. casei strains from different sources. 


\section{MATERIALS AND METHODS}

\section{Strains and growth conditions}

Lactobacillus strains used in this study are listed in Table 1. All strains were grown in MRS broth (BD Difco, Le Pont de Claix, France) at $37^{\circ} \mathrm{C}$ under static conditions. For preparing solid medium, the broth was supplemented with $1.8 \%$ agar. Plates were incubated in anaerobic jars at $37^{\circ} \mathrm{C}$.

Table 1. Strains used in this study

\begin{tabular}{|c|c|c|}
\hline strain & origin/reference & selected characteristics \\
\hline \multicolumn{3}{|l|}{ L. casei } \\
\hline BL23 & CECT $5275^{a}$ & $\begin{array}{l}\text { laboratory strain; } \\
\text { sequenced genome }\end{array}$ \\
\hline BL32 & CECT4040 & cheese isolate \\
\hline BL82 & ATCC $25598^{b}$ & sour milk isolate \\
\hline BL83 & CECT4043 & cheese isolate \\
\hline BL87 & ATCC11578 & oral cavity isolate \\
\hline BL90 & ATCC334 & $\begin{array}{l}\text { cheese isolate; } \\
\text { sequenced genome }\end{array}$ \\
\hline BL91 & ATCC4545 & dental caries isolate \\
\hline BL193 & laboratory stock & $\begin{array}{l}\text { isolated from } \\
\text { commercial probiotic drink }\end{array}$ \\
\hline BL208 & laboratory stock & human intestinal isolate \\
\hline BL212 & CRL686 ${ }^{\mathrm{C}}$ & dry cured sausage isolate \\
\hline BL227 & laboratory stock & commercial probiotic \\
\hline BL229 & laboratory stock & commercial probiotic \\
\hline \multicolumn{3}{|c|}{ L. plantarum } \\
\hline $\begin{array}{l}299 v \\
299 v \text { Adh- }\end{array}$ & $\begin{array}{l}\text { DSM9843 } \\
\text { (Mack, et al., 2003) }\end{array}$ & $\begin{array}{l}\text { human intestinal isolate } \\
\text { spontaneous mutant from } \\
299 v \text { with reduced } \\
\text { binding to HT- } 29 \text { cells }\end{array}$ \\
\hline
\end{tabular}

${ }^{a}$ Colección Española de Cultivos Tipo; ${ }^{b}$ American Type Culture Collection;

${ }^{\mathrm{c} C}$ Centro de Referencia para Lactobacilos; ${ }^{\mathrm{d}}$ Deutsche Sammlung von

Mikroorganismen und Zellkulturen 


\section{CAPÍTULO 1}

\section{Adhesion to solvents test}

Microbial adhesion to solvent (MATS) tests was performed essentially as described (Bellon-Fontaine, 1996). Five $\mathrm{ml}$ of overnight cultures of each strain were washed with phosphate-buffered saline (PBS; pH 7.2) and resuspended in PBS to a final $\mathrm{OD}_{600 \mathrm{~nm}}$ of $0.4\left(\mathrm{~A}_{0}\right)$. Three $\mathrm{ml}$ of this suspension were mixed with $1 \mathrm{ml}$ of different solvents (chloroform, ethyl-acetate or hexadecane) and the mixture was vortexed for $1 \mathrm{~min}$ at full speed. The mixture was let to stand for 20 min to allow phase separation and the absorbance of the aqueous phase was measured at $600 \mathrm{~nm}\left(A_{1}\right)$. The percentage of adhesion was calculated from: \%Adhesion $=100 \times\left[1-\left(A_{1} / A_{0}\right)\right]$. Each experiment was done in triplicate with cells coming from independent cultures.

\section{Ex vivo binding assay}

Resected mucosal colonic samples were obtained from patients subjected to colonic surgery at the Department of Pathological Anatomy Hospital Vall d'Hebron, Barcelona, and were immediately transferred to the laboratory.

Macroscopically healthy mucosal specimens were gently washed with cold saline and cut into $25-35 \mathrm{mg}$ pieces which included both mucosal and submucosal layers. Mucosal explants were then placed and orientated so that the epithelial surface was uppermost on culture filter plates ( $15 \mathrm{~mm}$-diameter wells with $500 \mu \mathrm{m}$ bottommesh, Netwell culture systems, Costar, Cambridge, MA) containing $1500 \mu \mathrm{l}$ of RPMI 1640 medium (CanSera, Rexdale, Ontario, Canada) plus $10 \%$ fetal bovine serum (Gibco BRL, Eggenstein, Germany).

A combination of antibiotics $50 \mu \mathrm{g} / \mathrm{ml}$ gentamycin (Normon, Madrid, Spain), $16 \mu \mathrm{g} / \mathrm{ml}$ vancomycine (Lilly, Indianapolis, USA) and $2500 \mathrm{U} / \mathrm{ml}$ colistine (Pharmax, Kent, UK) was added to the media in order to eradicate endogenous flora and the incubation lasted 3 hours at $37 \% \mathrm{C}$ in a humidified $5 \% \mathrm{CO}_{2}$ atmosphere. Traces of antibiotics were eliminated after intense washing with saline and mucosal explants were then incubated under the same conditions with RPMI 1640 medium plus 10\% fetal bovine serum, together with $10^{6} \mathrm{cfu} / \mathrm{ml}$ of each Lactobacillus strain. 
For each patient, each strain was tested in quadruplicate. After 4 hours of incubation, triplicates from each condition were removed and washed with $10 \mathrm{ml}$ of PBS in a tube rotator for 90 seconds at room temperature. The RPMI medium from the triplicates, the washing buffer and the washed mucosal fragments (homogenised in $1 \mathrm{ml}$ of PBS) were plated separately on MRS agar plates and incubated for 48 hours in a humidified $5 \% \quad \mathrm{CO}_{2}$ atmosphere.

The adherence was calculated as [cfu in the tissue/ total cfu (tissue + RPMI medium + washing buffer)] $x$ 1000. The fourth/remaining sample of RPMI incubated media and a tissue from each quadruplicated condition was stored at $-80^{\circ} \mathrm{C}$ for its later analysis of $\mathrm{pH}$ and lactate dehydrogenase activity (LDH) as a viability measurement of the tissue.

Viability was assessed in all tissues through the release of LDH into the supernatant according to (Finnie, et al., 1995)). The ratio of LDH activity in the culture supernatant over total LDH activity in tissue homogenates was calculated and used to estimate the percentage of viable tissue. Mucosal samples were homogenized in Tris/HCl (100 mM pH 7.4) and LDH activity was analysed by the spectrophotometric method (Pyruvate-Lactate) recommended by the Scandinavian Society of Enzymes.

Each strain was assayed against resected mucosal explants from four to six patients (mean age $70 \pm 18$ years). Prior informed consent was obtained from every patient, and the study had been approved by the Ethics Committee of our Institution (Comitè d'Ètica I Investigació Clínica, Hospital Universitari Vall d’Hebron). 


\section{CAPÍTULO 1}

\section{Microtitre plate binding assays}

All strains were assayed for binding to different substrates immobilized on 96-well immunoplates. Plates were covered with the different substrates overnight at $4 \stackrel{\circ}{ } \mathrm{C}$.

Mucin (porcine stomach, Sigma), fibrinogen (fraction I from pig plasma, Sigma), fibronectin (human plasma, Sigma) and collagen (type I, Roche) were used at $500 \mu \mathrm{g} / \mathrm{ml}$ (mucin) or $50 \mu \mathrm{g} / \mathrm{ml}$ (fibrinogen, fibronectin and collagen) in $50 \mathrm{mM}$ carbonate/bicarbonate buffer pH 9.6 (mucin, fibrinogen and fibronectin) or PBS pH 5.5 (collagen). 96-well Maxisorp plates (Nunc) were used for mucin and collagen, whereas Polysorp plates (Nunc) were used for fibrinogen and fibronectin.

After immobilization, wells were washed three times with PBS and blocked for 1 hour with PBS plus 1\% Tween 20. One hundred $\mu \mathrm{l}$ of each strain were added to each well in PBS adjusted to an $\mathrm{OD}_{550 \mathrm{~nm}}$ of 1 and plates were incubated overnight at $4^{\circ} \mathrm{C}$. Nonadhered cells were removed by washing three times with $200 \mu \mathrm{l}$ of PBS plus $0.05 \%$ Tween 20 and the plates were dried at 55으. Adhered cells were stained with crystal violet $1 \mathrm{mg} / \mathrm{ml}$ (100 $\mu \mathrm{l} /$ well) for 45 minutes. After 6 washes with PBS, the colorant was liberated with 50 $\mathrm{mM}$ citrate buffer $\mathrm{pH} 4.0(100 \mu \mathrm{l} /$ well) for 45 minutes and the absorbance at $595 \mathrm{~nm}$ was determined in a Multiskan Ascent plate reader (Labsystems).

For testing the effect of mucin presence in the growth medium, cells were grown in MRS broth supplemented with 0.1 (weight/volume) mucin. The effect of protease treatment was assayed by incubating the cells at an $\mathrm{OD}_{550 \mathrm{~nm}}$ of 1 in PBS with 100 $\mu \mathrm{g} / \mathrm{ml}$ of proteinase $\mathrm{K}$ (Roche) at $37^{\circ} \mathrm{C}$ for 1 hour. After incubation, the protease was inactivated by addition of $1 \mathrm{mM}$ phenylmethylsulfonyl fluoride followed by two washes with PBS. Cells were resuspended in PBS to an $\mathrm{OD}_{550 \mathrm{~nm}}$ of 1 and used for binding assays. Control cells were treated exactly as digested cells but without the addition of proteinase $\mathrm{K}$. 
Blank wells without bound substrates were run as controls in all experiments, which were carried out in triplicate three times with cells coming from independent cultures

\section{Yeast agglutination assay}

The method of (Kos, et al., 2003) was used with slight modifications. Cells were grown overnight in $5 \mathrm{ml}$ of MRS, washed with PBS and resuspended in $1 \mathrm{ml}$ of PBS. Fifty $\mu \mathrm{l}$ of a 1:4 dilution of this suspension were transferred to the wells of a microtitre plate and $50 \mu \mathrm{l}$ of PBS plus $100 \mu \mathrm{l}$ of a $1 \%$ (weight/volume) mixture of baker's yeast in PBS were added to each well. The plates were incubated for $10 \mathrm{~min}$ with mild agitation and the capacity to agglutinate yeast was observed under the microscope (400X).

\section{Bioinformatic analysis}

The presence of Mub or Msa homologues was searched in BL23 and BL90 (ATCC334) encoded proteins (Genbank FM177140 and CP000423, respectively) by using the Blastp algorithm. Search for proteins carrying MucBP domains was carried out with Hmmer

(http://hmmer.wustl.edu/) using the Pfam MucBP, alignment model (PF06458). 


\section{CAPÍTULO 1}

\section{RESULTS}

\section{Adhesion properties to solvents}

Microbial adherence is related to the cell surface characteristics, including hydrophobicity and charges. We used the microbial adhesion to solvents test (MATS) to measure surface characteristics in L. casei strains by measuring affinity to chloroform (acidic solvent and electron acceptor), ethyl-acetate (basic solvent and electron donor) and hexadecane (hydrophobic solvent) (BellonFontaine, 1996).

The study included strains that were isolated from food environments and strains of human origin (intestinal and oral isolates), together with strains that are being used as commercial probiotics (Table 1). In addition, one strain of a well characterized probiotic (Lactobacillus plantarum 299v), together with an isogenic mutant defective in the mannose-sensitive adhesion to mucus (Mack, et al., 2003) were used as controls.

Most of the strains had an affinity of more than $90 \%$ to the acidic solvent chloroform. With the exception of strains BL90, BL193 and BL212, adhesion to the basic solvent ethyl-acetate was low (10 to $20 \%$ ), thus confirming the non-acidic character of the surface of nearly all strains. Percentages of adherence to the apolar solvent hexadecane varied among strains with strongly hydrophobic (BL23, BL90, BL193, BL212), displaying more than $60 \%$ adhesion, to hydrophilic strains (BL83, BL208, BL229), which showed less than $10 \%$ affinity. L. plantarum $299 \mathrm{v}$ exhibited basic and relatively hydrophilic characteristics ( $18 \%$ adherence to hexadecane). Its isogenic mutant $299 \mathrm{v} \mathrm{Adh}^{-}$showed a reduction in the affinity to chloroform and ethyl acetate and a strongly hydrophilic surface (less than $1 \%$ adhesion to hexadecane). 
Figure 1 MATS test of different lactobacilli strains. The percentages of adhesion to A, chloroform; $\mathbf{B}$, ethyl-acetate and $\mathbf{C}$, hexadecane, are shown. Error bars represent standard deviations.

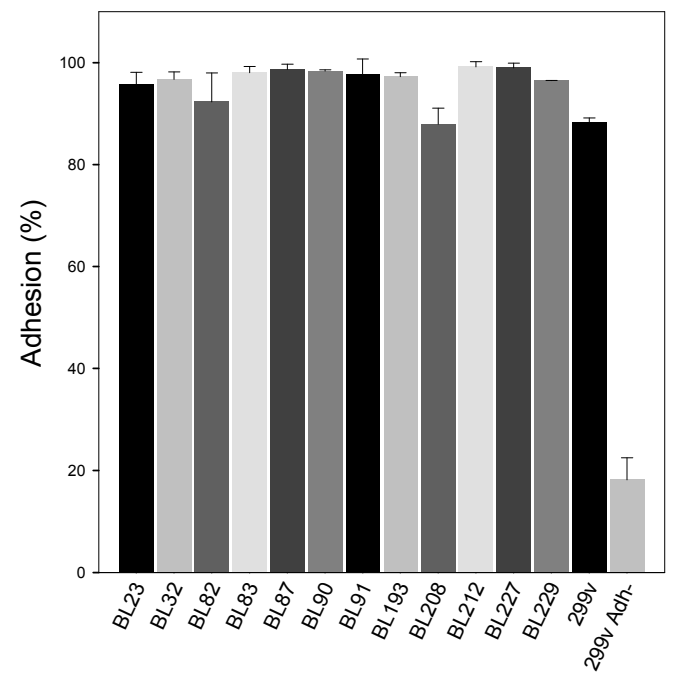

Figure 1A. Percentages of adhesion to chloroform.

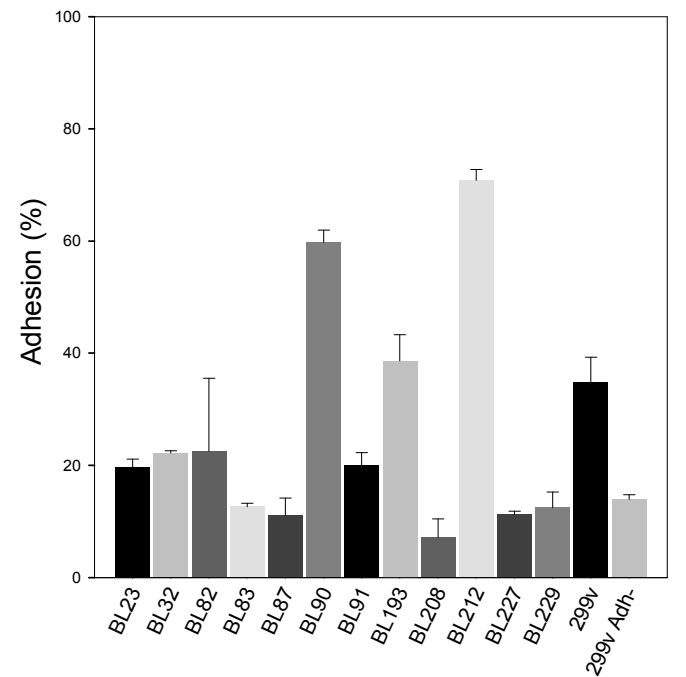

Figure 1B. Percentages of adhesion to ethyl-acetate. 


\section{CAPÍTULO 1}

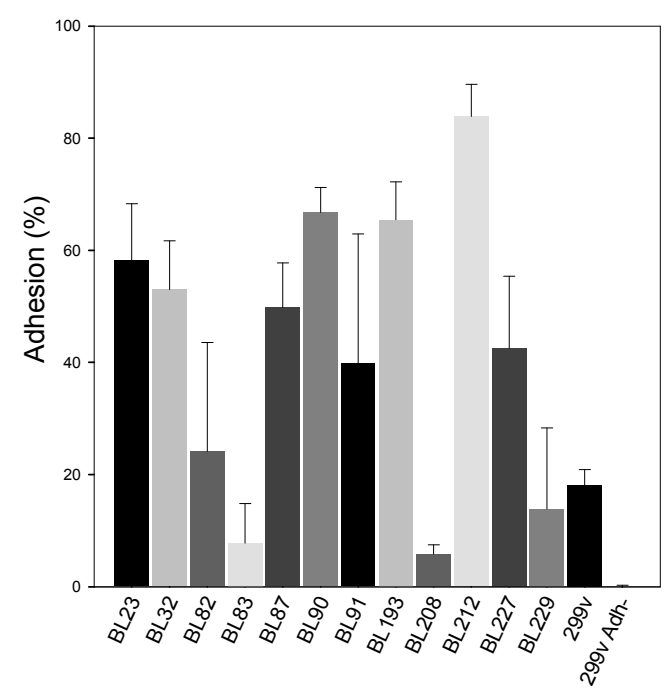

Figure 1C. Percentages of adhesion to hexadecane.

\section{Binding to human colon fragments ex vivo}

Ex vivo binding to resected human mucosa fragments has been described as a reliable method for measuring bacterial adhesion, as it contains the mucosal layer which bacterial cells encounter in vivo during their passage through the digestive tract (Ouwehand, et al., 2002). L. casei strains adhere to colon fragments of healthy individuals at different levels (Figure 2).

Commercial probiotics (BL193, BL229) or intestinal isolates (BL208) were not among the most adherent strains. Three strains (BL23, BL87 and BL227) showed the highest binding capacity while, in general, strains from food origin showed the lowest capacity.

The overall level of adhesion was low, which agrees to other models of in vivo and in vitro binding to non-lymphoid intestinal epithelium by lactobacilli (Plant \& Conway, 2001, Ouwehand, et al., 2002, Ouwehand, et al., 2003). As expected, L. plantarum 299v Adh lost its binding ability to human epithelium compared to its parental strain. 


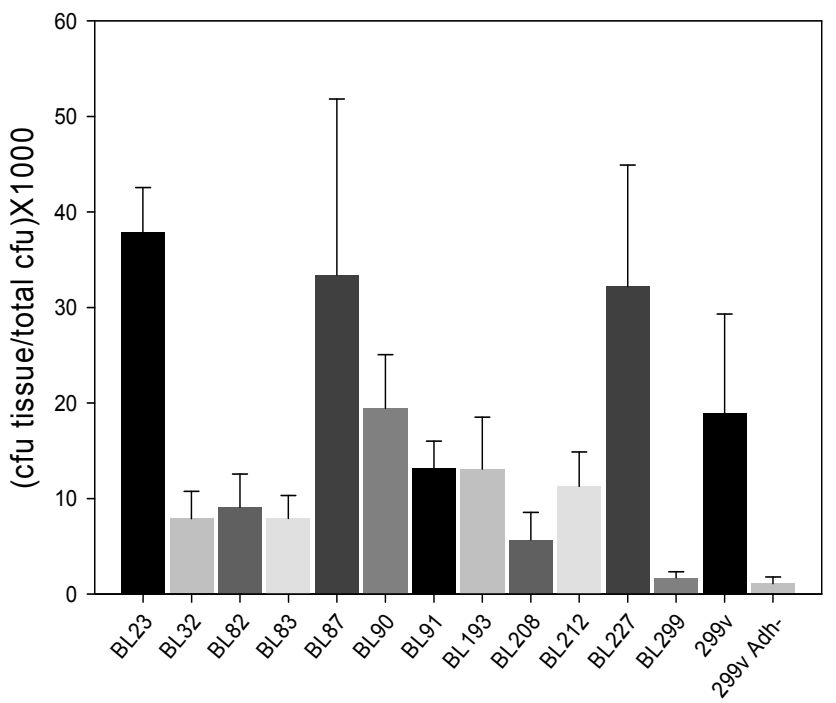

Figure 2. Binding of Lactobacillus strains to human resected colon fragments in culture medium. Data represent means plus standard deviations of experiments carried out with tissue fragments from four to six patients.

\section{In vitro binding to mucin and ECM components}

In an attempt to determine whether binding to resected mucosa correlated with binding of molecules present in the mucus or the ECM, we measured the binding to mucin, collagen, fibronectin or fibrinogen immobilized on the surface of immunoplates. With the exception of BL87, BL227 and 299v, strains showed very low or non detectable binding to mucin (Figure $3 a$ ).

It has been described that the adherence to mucus in several Lactobacillus reuteri strains is an inducible characteristic triggered by the presence of mucin in the growth medium (Jonsson, et al., 2001). To test whether this possibility might explain the absence of mucin binding detected in this study, strains were grow in the presence of mucin and tested for mucin binding. 


\section{CAPÍTULO 1}

\section{Figure 3}

Binding of Lactobacillus strains to different substrates immobilized in microtitre plates. A, mucin; B, collagen; C, fibronectin; D, fibrinogen. In panel $\mathbf{A}$, cells used in the experiments were grown in MRS with or without $0.1 \%$ mucin. Error bars show standard deviations.

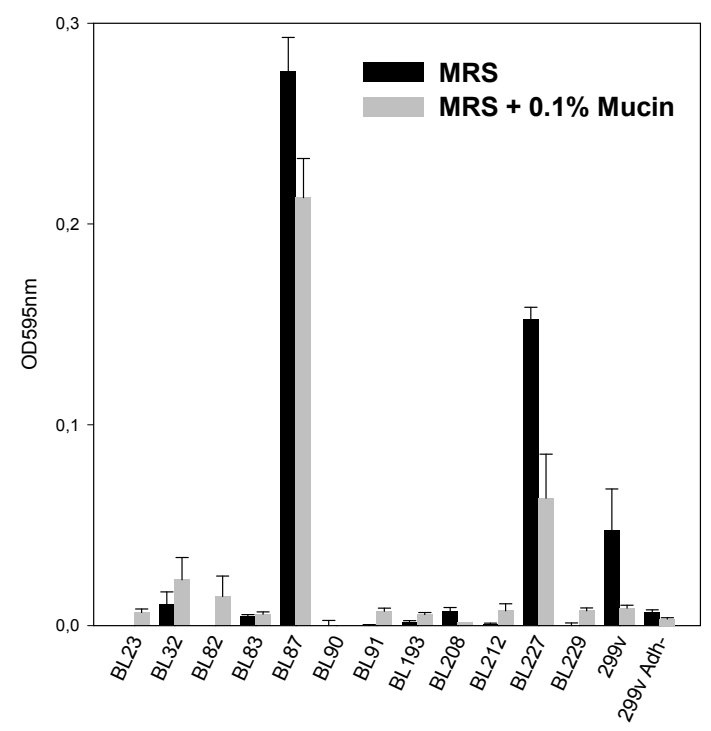

Figure 3A. Binding of Lactobacillus strains to mucin. Cells used in the experiments were grown in MRS with or without $0.1 \%$ mucin. Error bars show standard deviations.

The addition of mucin had no major effect in the adhesion capacity of the non-adherent strains. On the contrary, addition of mucin to the growth medium of adherent strains (BL87, BL227 and 299v) resulted in a decrease of their adhesion capacity (Figure 3a). Interestingly, with the exception of BL23 strain, adhesion to mucin by BL87, BL227 and 299v strains correlated with their adhesion to resected mucosa.

Mucin-binding proteins have been characterized in many $L$. plantarum strains and shown to be dependent on mannose-sensitive adhesins (Adlerberth, et al., 1996). 
The presence of these adhesins on the cell surface can be easily assayed, as they confer the capacity to agglutinate Saccharomyces cerevisiae cells. None of the L. casei strains were able to aggregate yeast, while the control L. plantarum 299v showed strong agglutination (data not shown). As expected, the control strain $299 \mathrm{v} \mathrm{Adh}^{-}$was negative in agglutination tests and bound less to mucin.

Collagen and fibronectin are components of the ECM and fibrinogen forms the blood clot. These three proteins are common targets for bacterial attachment, including lactobacilli (Velez, et al., 2007). L. casei strains adhere to the three substrates (Fig $3 b, 3 c$ and $3 d)$.

Some strains, like BL23, BL90 or BL91, had an intermediate binding ability to the three proteins, whereas BL212, a very hydrophobic strain, showed the lowest adherence to all ECM components. BL87, the strain showing the highest mucin-binding capacity did not adhere very strongly, whereas the mucin-binding strain BL227 strongly adhered to collagen (Fig 3b) and had an intermediate binding to fibronectin and fibrinogen. The highest adherence for the three substrates was found for BL32 (cheese isolate) and BL193 (commercial probiotic), showing that no clear correlation could be found between the origin of the strain and their adhesive properties.

The L. plantarum $299 \mathrm{v}$ control strain was the only strain showing a strong binding to all substrates, which was reduced in the Adh- mutant by $90 \%$ to $94 \%$. This mutant was isolated as a strain unable to aggregate yeast cells and had a reduction in the binding to HT-29 cultured epithelial cells (Mack, et al., 2003). MATS test and adhesion studies showed that this mutant has profound changes in its surface characteristics. 


\section{CAPÍTULO 1}

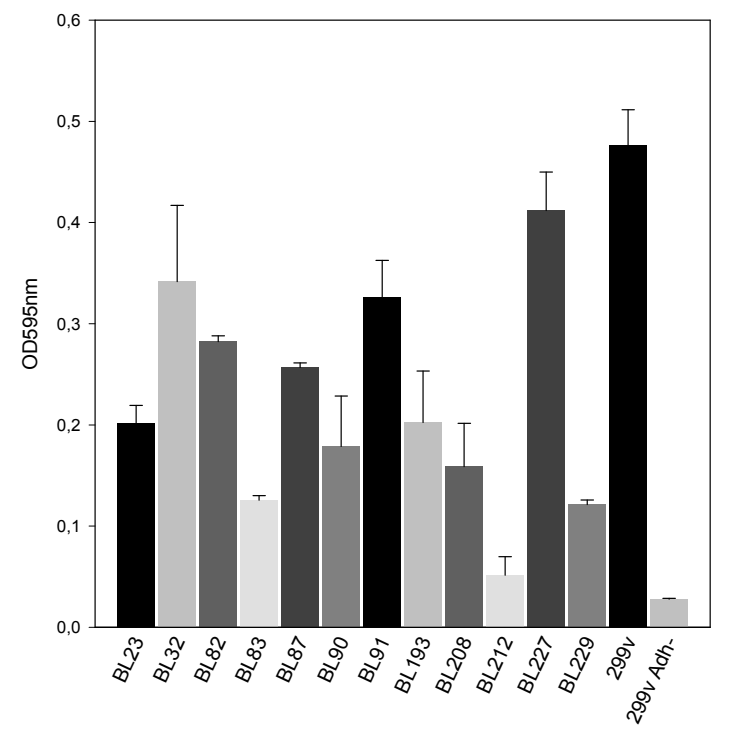

Figure 3B. Binding of Lactobacillus strains to collagen. Error bars show standard deviations.

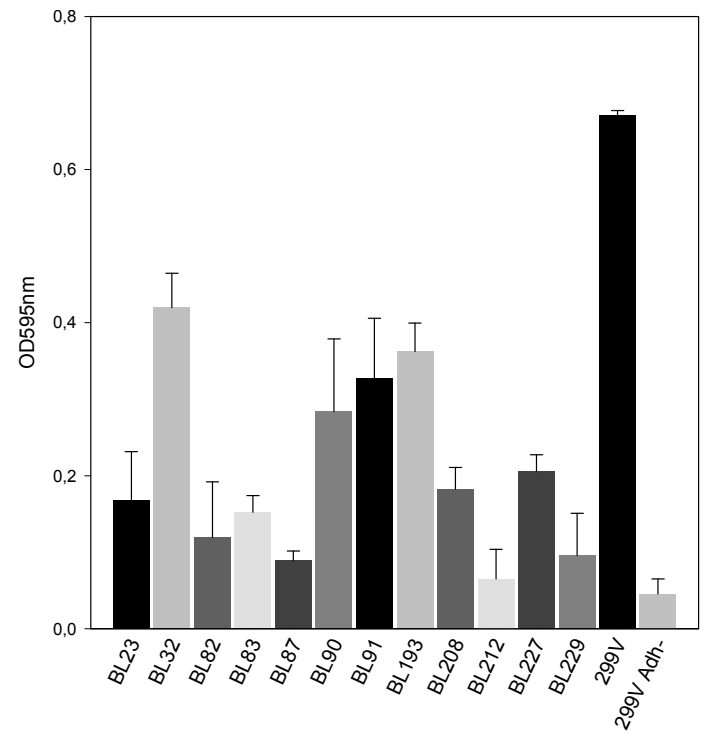

Figure 3C. Binding of Lactobacillus strains to fibronectin. Error bars show standard deviations. 


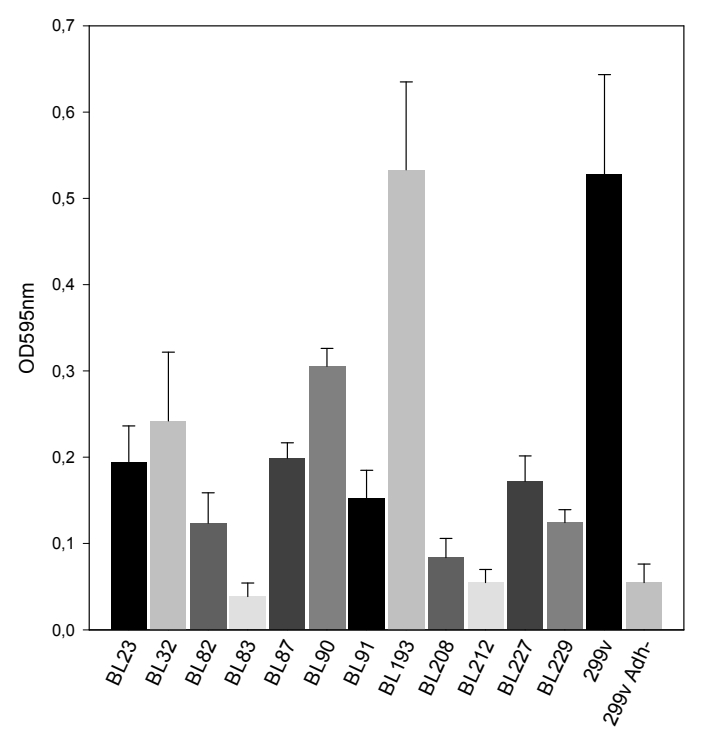

Figure 3D. Binding of Lactobacillus strains to fibrinogen. Error bars show standard deviations.

Specific surface adhesins have been described in some Lactobacillus species as responsible for binding of mucin, collagen and fibronectin (Lorca, et al., 2002). In order to test whether proteic factors could contribute to the adhesion properties, selected strains were tested for adhesion after proteinase $K$ treatment of the cells.

In general, protease treatment reduced the binding to all target substances (Figure 4) except in BL87 and BL227 strains, where binding was increased for all substances from 1.3- to 17-fold. In the rest of strains the most drastic decrease in binding ability was shown for fibronectin, with a reduction ranging from 3.4- to 49-fold after protease digestion (Figure 4c), whereas collagen and fibrinogen binding was reduced by 1.3- to 4.6 -fold (Figures $4 \mathrm{~b}$ and $4 \mathrm{~d}$ ).

These results suggest that protein determinants exposed to the cell surface are, at least partly, involved in adhesion to collagen, fibronectin and fibrinogen in the analyzed $L$. casei strains. 


\section{CAPÍTULO 1}

Figure 4. Effect of protease treatment in the binding activity of selected strains. Cells resuspended in PBS were subjected to digestion with proteinase $\mathrm{K}(100 \mu \mathrm{g} / \mathrm{ml})$ for 1 hour at $37^{\circ} \mathrm{C}$ and used in binding studies to $\mathbf{A}$, mucin; B, collagen; C, fibronectin and D, fibrinogen. Error bars represent standard deviations.

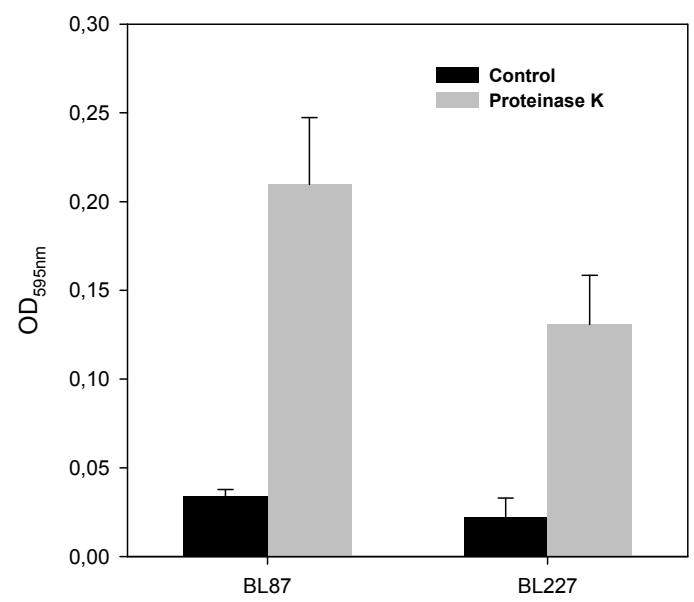

Figure 4A. Effect of protease treatment in the binding activity of selected strains to mucin.

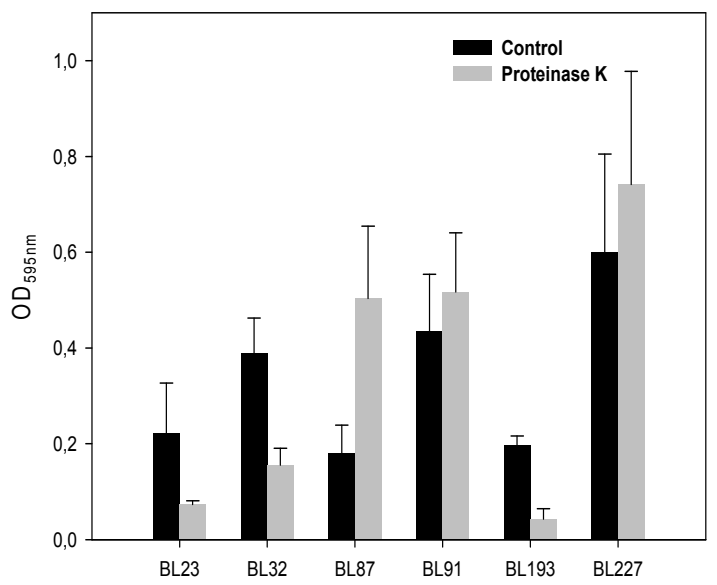

Figure 4B. Effect of protease treatment in the binding activity of selected strains to collagen. 


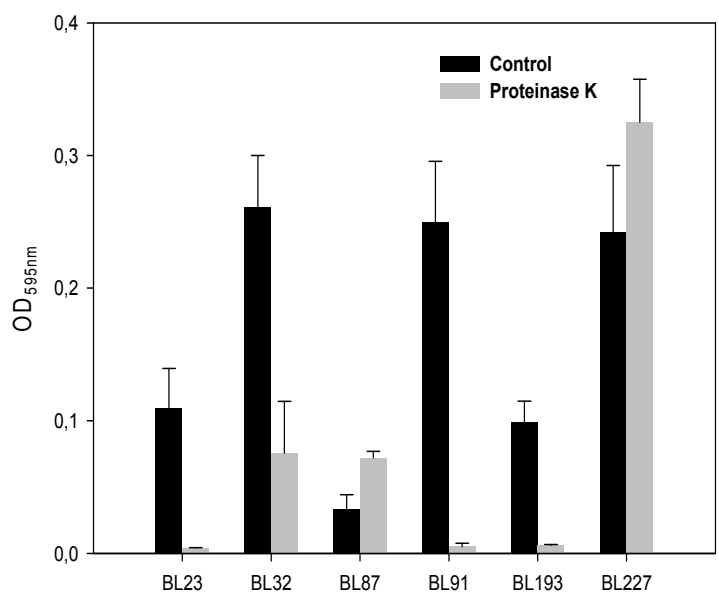

Figure 4C. Effect of protease treatment in the binding activity of selected strains to fibronectin.

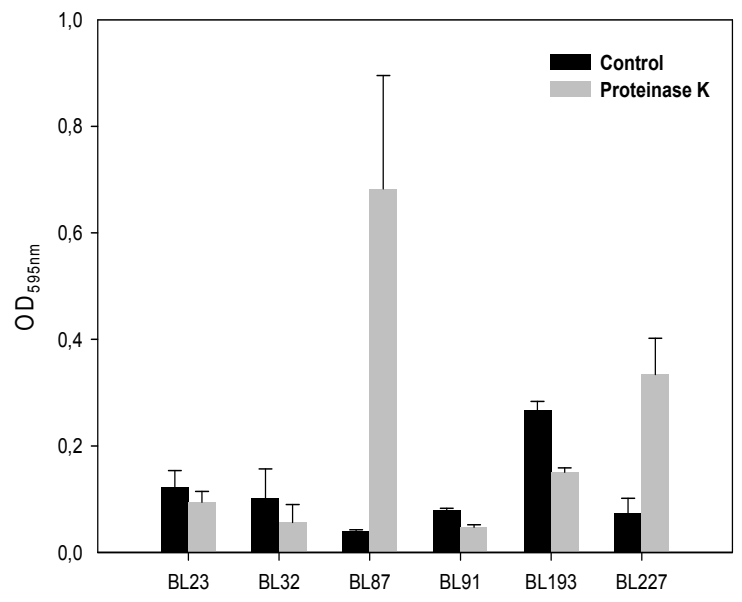

Figure 4D. Effect of protease treatment in the binding activity of selected strains to fibrinogen. 


\section{CAPÍTULO 1}

\section{DISCUSSION}

Adhesion to the intestinal mucosa could be crucial for a probiotic to exert its beneficial health effects.

The physicochemical surface characteristics of bacteria are important in the first reversible interactions that precede bacterial adhesion (Abraham, 1999). Previous adhesion studies to solvents with different Lewis-acid/base characteristics have demonstrated that $L$. casei strains have a strong basic and weak acidic character (Pelletier, et al., 1997). Basically, similar results were obtained in this work, with the exception that some strains displayed a dual behaviour, showing strong affinity for both chloroform and ethylacetate. However, the higher adhesion to chloroform observed in all strains supports the basic nature of the cell surfaces. Some works have reported the hydrophilic nature of lactobacilli, and L. casei in particular (Pelletier, et al., 1997). Although several of the strains characterized here displayed a hydrophilic surface (10 to $20 \%$ adhesion to hexadecane), a high hydrophobicity (more than $50 \%$ adhesion) was found in other strains, for which we assume that a high inter-strain variation is found for this character.

Highly hydrophobic cell surfaces are sometimes associated with autoaggregating capacity (Collado, et al., 2007), which in some cases determines the intestinal colonization (Voltan, et al., 2007). In addition, some authors have correlated the adhesion ability of lactobacilli to their surface hydrophobicity (Ehrmann, et al., 2002), whereas no correlation was observed by others (Vinderola, et al., 2004). In agreement with this, no association could be found between hydrophobicity and binding capacities of the strains studied here. Some strains (BL83, BL208 and BL229) displayed a hydrophilic surface and low adhesion, whereas low adhesion was observed in other highly hydrophobic strains (e.g. BL212).

In conclusion, further research is needed in order to characterize the role of LAB cell-wall hydrophobicity, as measured by MATS test, in bacterial adhesion. 
We have shown that some $L$. casei strains adhere to human resected intestinal mucosa, which correlates with the reported persistence of probiotic $L$. casei strains in the human intestinal tract in clinical trials (Oozeer, et al., 2006). Resected intestinal samples provide a good model to investigate $L A B$ adhesion by including interactions with the epithelium, mucus and the possibility to asses interactions with the resident microbiota (Ouwehand, et al., 2002). Mucin adhesion was paralleled to tissue adhesion in BL87 and BL227 strains. Epithelial cells are covered by the mucus, composed mainly of highly glycosilated mucins. Adhesion to this protective layer by lactobacilli is well documented both in vitro and in vivo (Ouwehand, et al., 2001, Vinderola, et al., 2004, Vesterlund, et al., 2005).

Mucus binding has been characterized in species such as $L$. plantarum and $L$. reuteri and it has been shown to depend on mannose-sensitive adhesins (Adlerberth, et al., 1996, Roos \& Jonsson, 2002). Two of such adhesins (Mub and Msa) have been purified and their genes cloned from L. reuteri 1063 (Roos \& Jonsson, 2002) and L. plantarum WCFS1 (Pretzer, et al., 2005). Mub and Msa are large multi-domain proteins (357 and $107 \mathrm{KDa}$, respectively) covalently attached to the cell surface by a sortase-dependent mechanism. Mucus-binding proteins from LAB contain several repetitions of a 100 to 200 amino-acids sequence which has been described as a mucin-binding domain (MucBP, Pfam database PF06458). This domain has only been detected in LAB (Boekhorst, et al., 2006) and proteins carrying it are abundant in strains from intestinal origin (Azcarate-Peril, et al., 2008).

The availability of the genome sequence of both BL90 (ATCC334, Genbank CP000423) and BL23 strains (Genbank FM177140), prompted us to look for the presence of Mub/Msa homologues or proteins carrying MucBP domains. However, no such proteins seem to be encoded within the BL90 or BL23 genomes (data not shown). 


\section{CAPÍTULO 1}

This correlated with the inability of most of the tested L. casei strains to bind mucin, with the lack of yeast agglutination activity and with the low mucus or mucin binding capacity of L. casei strains described by others (Ouwehand, et al., 2002, Styriak, et al., 2003). We only detected mucin binding activity in strains BL87 and BL227 and, in this case, binding was not dependent on proteins. On the contrary, protease treatment of these strains, which was probably producing changes in the surface hydrophobicity, enhanced the binding to mucin and proteins of the ECM.

In $L$. reuteri, mucus binding in a variety of strains is dependent on the presence of mucin in the growth medium (Jonsson, et al., 2001). Therefore, it is suggested that inducible cell surface proteins with mucus-binding activity are produced. Moreover, expression of $m s a$ in L. plantarum 423 was up-regulated by the presence of mucin (Ramiah, et al., 2007).

The opposite effect was found in L. casei BL87 and BL227, where mucin present in the growth medium is likely to attach and block mucin-binding sites on the cell surfaces, which could explain the inhibitory effect. BL227 strain is a commercial probiotic, whereas BL87 is an oral isolate. It is likely that the ability to proliferate in a complex medium such as the oral cavity might provide BL87 with the surface characteristics necessary for mucosa attachment.

A third strain, BL23, adhered to the mucosa but showed no mucin binding. This strain is thus using other surface traits for mucosal binding. The origin of BL23 strain is uncertain (Acedo-Felix \& Perez-Martinez, 2003), but it has been used by many laboratories in both genetic and physiology studies for years and its genome has been recently sequenced. In addition, it showed anti-inflammatory effects after oral administration in mice inflammatory bowel disease models (Foligne, et al., 2007).

The ECM forms a complex structure surrounding epithelial cells, but molecules from the ECM can be shed from the epithelium to the mucus. Moreover, if the mucosa is damaged, the ECM can be exposed, allowing microbial colonization and infection (Westerlund \& Korhonen, 1993). 
For this reason, binding to ECM proteins by lactobacilli can play a role in competition and displacement of pathogens (Lorca, et al., 2002, Styriak, et al., 2003). The adhesion experiments reported here showed that some strains were able to adhere to ECM proteins and that this was linked (except for BL87 and BL227 strains) to the presence of proteic factors on their surfaces.

Several proteins have been characterized in lactobacilli as responsible for collagen and fibronectin binding (Aleljung, et al., 1994, Lorca, et al., 2002, de Leeuw, et al., 2006, Velez, et al., 2007). CnBP from L. reuteri NCIB 11951 is a collagen-binding protein which forms part of an $A B C$-type bacterial transporter (solute binding protein) (Aleljung, et al., 1994). It seems therefore that some of the factors promoting binding to ECM proteins are moonlighting proteins implicated in other cellular processes. Similarly, the transcriptional elongation factor Tu (EF-Tu) or the molecular chaperone GroEL from L. johnsonii La1 (Granato, et al., 2004, Bergonzelli, et al., 2006) and the glyceraldehyde-3-phosphate dehydrogenase from $L$. plantarum LA318 (Kinoshita, et al., 2008) are surface-located and mediate binding to epithelial cells and mucus. No such proteins have been described for L. casei, but L. casei BL9O and BL23 carry a gene encoding a hypothetical fibronectin-binding protein (LSEI_1439 and LCABL_16620, respectively) homologous to FbpA from Streptococcus gordonii (Christie, et al., 2002) and L. acidophilus NCFM (Buck, et al., 2005), nevertheless, its implication in fibronectin binding is still unknown.

The adhesion properties studied in this work showed a high intra-species variability. Furthermore, clear adhesion profiles could not be attributed to commercial probiotics, food or human isolates. While studying adhesion to collagen, fibrinogen and mucus in LAB from different origins (faecal, clinical isolates and commercial probiotics, including dairy strains) (Vesterlund, et al., 2007) reported that no statistical significant difference could be found in the adhesion of strains from the three different groups. 


\section{CAPÍTULO 1}

Although the number of strains used in the present work is low, it strengthens the idea that individualized and careful analysis of each potential probiotic has to be performed and suggests that adhesion factors are widespread in $L$. casei from different origins.

\section{ACKNOWLEDGEMENTS}

This work was financed by funds of the Spanish Ministerio de Ciencia e Innovación (AGL2004-00176 and Consolider Fun-c-Food CSD2007-00063). Diego Muñoz-Provencio was supported by a predoctoral fellowship from the Conselleria de Cultura of the Generalitat Valenciana. We thank Siv Ahrne and Goran Molin (Department of Food Technology, Lund University, Lund, Sweden) for providing us with the strains L.plantarum 299v and 299v Adh-. 


\section{REFERENCES}

Abraham SN, Sharon, N. and Ofek, I. (1999) Adhesion of bacteria to mucosal surfaces. Academic Press, New York.

Acedo-Felix E \& Perez-Martinez G (2003) Significant differences between Lactobacillus casei subsp. casei ATCC 393T and a commonly used plasmid-cured derivative revealed by a polyphasic study. Int J Syst Evol Microbiol 53: 6775.

Adlerberth I, Ahrne S, Johansson ML, Molin G, Hanson LA \& Wold AE (1996) A mannose-specific adherence mechanism in Lactobacillus plantarum conferring binding to the human colonic cell line HT-29. Appl Environ Microbiol 62: 2244-2251.

Aleljung $\mathrm{P}$, Shen W, Rozalska B, Hellman $U$, Ljungh A \& Wadstrom $T$ (1994) Purification of collagenbinding proteins of Lactobacillus reuteri NCIB 11951. Curr Microbiol 28: 231-236.

Azcarate-Peril MA, Altermann E, Goh YJ, et al. (2008) Analysis of the genome sequence of Lactobacillus gasseri ATCC 33323 reveals the molecular basis of an autochthonous intestinal organism. Appl Environ Microbiol.

Bellon-Fontaine MR, J; vanOss, CJ (1996) Microbial adhesion to solvents: A novel method to determine the electron-donor/electron-

acceptor or Lewis acid-base properties of microbial cells Colloids and Surfaces $B$ : biointerfaces 7: 47-53.
Bergonzelli GE, Granato D, Pridmore RD, Marvin-Guy LF, Donnicola D \& Corthesy-Theulaz IE (2006) GroEL of Lactobacillus johnsonii La1 (NCC 533) is cell surface associated: potential role in interactions with the host and the gastric pathogen Helicobacter pylori. Infect Immun 74: 425-434.

Boekhorst J, Helmer Q, Kleerebezem M \& Siezen RJ (2006) Comparative analysis of proteins with a mucus-binding domain found exclusively in lactic acid bacteria. Microbiology 152: 273-280.

Buck BL, Altermann E, Svingerud T \& Klaenhammer TR (2005) Functional analysis of putative adhesion factors in Lactobacillus acidophilus NCFM. Appl Environ Microbiol 71: 8344-8351.

Collado MC, Surono I, Meriluoto J \& Salminen S (2007) Indigenous dadih lactic acid bacteria: cellsurface properties and interactions with pathogens. J Food Sci 72: M89-93.

Christie J, McNab R \& Jenkinson HF (2002) Expression of fibronectin-binding protein FbpA modulates adhesion in Streptococcus gordonii. Microbiology 148: 1615-1625.

de Leeuw E, Li X \& Lu W (2006) Binding characteristics of the Lactobacillus brevis ATCC 8287 surface layer to extracellular matrix proteins. FEMS Microbiol Lett 260: 210-215.

Ehrmann MA, Kurzak P, Bauer J \& Vogel RF (2002) Characterization of lactobacilli towards their use as 


\section{CAPÍTULO 1}

probiotic adjuncts in poultry. $J$ Appl Microbiol 92: 966-975.

Finnie IA, Dwarakanath AD, Taylor BA \& Rhodes JM (1995) Colonic mucin synthesis is increased by sodium butyrate. Gut 36: 93-99.

Foligne B, Nutten S, Grangette C, et al. (2007) Correlation between in vitro and in vivo immunomodulatory properties of lactic acid bacteria. World J Gastroenterol 13: 236-243.

Granato D, Bergonzelli GE, Pridmore RD, Marvin L, Rouvet M \& CorthesyTheulaz IE (2004) Cell surfaceassociated elongation factor Tu mediates the attachment of Lactobacillus johnsonii NCC533 (La1) to human intestinal cells and mucins. Infect Immun 72: 2160-2169.

Jonsson H, Strom E \& Roos S (2001) Addition of mucin to the growth medium triggers mucus-binding activity in different strains of Lactobacillus reuteri in vitro. FEMS Microbiol Lett 204: 19-22.

Kinoshita $\mathrm{H}$, Uchida $\mathrm{H}$, Kawai $\mathrm{Y}$, et al. (2008) Cell surface Lactobacillus plantarum LA 318 glyceraldehyde-3-phosphate dehydrogenase (GAPDH) adheres to human colonic mucin. J Appl Microbiol 104: 1667-1674.

Kos B, Suskovic J, Vukovic S, Simpraga M, Frece J \& Matosic S (2003) Adhesion and aggregation ability of probiotic strain Lactobacillus acidophilus M92. J Appl Microbiol 94: 981-987.

Lorca G, Torino MI, Font de Valdez G \& Ljungh AA (2002) Lactobacilli express cell surface proteins which mediate binding of immobilized collagen and fibronectin. FEMS Microbiol Lett 206: 31-37.

Mack DR, Ahrne S, Hyde L, Wei S \& Hollingsworth MA (2003) Extracellular MUC3 mucin secretion follows adherence of Lactobacillus strains to intestinal epithelial cells in vitro. Gut 52: 827-833.

Oozeer R, Goupil-Feuillerat N, Alpert CA, van de Guchte $M$, Anba J, Mengaud J \& Corthier G (2002) Lactobacillus casei is able to survive and initiate protein synthesis during its transit in the digestive tract of human floraassociated mice. Appl Environ Microbiol 68: 3570-3574.

Oozeer R, Leplingard A, Mater DD, et al. (2006) Survival of Lactobacillus casei in the human digestive tract after consumption of fermented milk. Appl Environ Microbiol 72: 5615-5617.

Ouwehand AC, Tuomola EM, Tolkko S \& Salminen S (2001) Assessment of adhesion properties of novel probiotic strains to human intestinal mucus. Int J Food Microbiol 64: 119-126.

Ouwehand AC, Salminen S, Roberts PJ, Ovaska J \& Salminen E (2003) Disease-dependent adhesion of lactic acid bacteria to the human intestinal mucosa. Clin Diagn Lab Immunol 10: 643-646.

Ouwehand AC, Salminen S, Tolkko S, Roberts $P$, Ovaska J \& Salminen E (2002) Resected human colonic tissue: new model for characterizing adhesion of lactic acid bacteria. Clin Diagn Lab Immunol 9: 184-186. 
Pelletier C, Bouley C, Cayuela C, Bouttier $S$, Bourlioux P \& Bellon-Fontaine MN (1997) Cell surface characteristics of Lactobacillus casei subsp. casei, Lactobacillus paracasei subsp. paracasei, and Lactobacillus rhamnosus strains. Appl Environ Microbiol 63: 17251731.

Plant L \& Conway P (2001) Association of Lactobacillus spp. with Peyer's patches in mice. Clin Diagn Lab Immunol 8: 320-324.

Pretzer G, Snel J, Molenaar D, et al. (2005) Biodiversity-based identification and functional characterization of the mannose-specific adhesin of Lactobacillus plantarum. J Bacteriol 187: 6128-6136.

Ramiah K, van Reenen CA \& Dicks LM (2007) Expression of the mucus adhesion genes Mub and MapA, adhesion-like factor EF-Tu and bacteriocin gene plaA of Lactobacillus plantarum 423, monitored with real-time PCR. Int J Food Microbiol 116: 405409.

Roos S \& Jonsson H (2002) A highmolecular-mass cell-surface protein from Lactobacillus reuteri 1063 adheres to mucus components. Microbiology 148: 433-442.

Styriak I, Nemcova R, Chang YH \& Ljungh A (2003) Binding of extracellular matrix molecules by probiotic bacteria. Lett Appl Microbiol 37: 329-333.

Tuomola EM \& Salminen SJ (1998) Adhesion of some probiotic and dairy Lactobacillus strains to Caco-2 cell cultures. Int J Food Microbiol 41: 45-51.
Velez MP, De Keersmaecker SC \& Vanderleyden J (2007) Adherence factors of Lactobacillus in the human gastrointestinal tract. FEMS Microbiol Lett 276: 140-148.

Vesterlund S, Paltta J, Karp M \& Ouwehand AC (2005) Adhesion of bacteria to resected human colonic tissue: quantitative analysis of bacterial adhesion and viability. Res Microbiol 156: 238-244.

Vesterlund S, Vankerckhoven V, Saxelin $M$, Goossens $H$, Salminen S \& Ouwehand AC (2007) Safety assessment of Lactobacillus strains: presence of putative risk factors in faecal, blood and probiotic isolates. Int J Food Microbiol 116: 325-331.

Vinderola CG, Medici M \& Perdigon G (2004) Relationship between interaction sites in the gut, hydrophobicity, mucosal immunomodulating capacities and cell wall protein profiles in indigenous and exogenous bacteria. J Appl Microbiol 96: 230-243.

Voltan S, Castagliuolo I, Elli $\mathrm{M}$, et al. (2007) Aggregating phenotype in Lactobacillus crispatus determines intestinal colonization and TLR2 and TLR4 modulation in murine colonic mucosa. Clin Vaccine Immunol 14: 1138-1148.

Westerlund B \& Korhonen TK (1993) Bacterial proteins binding to the mammalian extracellular matrix. Mol Microbiol 9: 687-694. 
CAPÍTULO 1 
CAPÍTULO 2

CAPÍTULO 2 
CAPÍTULO 2 


\section{CAPÍTULO 2}

\section{Characterization of a fibronectin-binding protein from Lactobacillus casei BL23}

Diego Muñoz-Provencio, Gaspar Pérez-Martínez and Vicente Monedero

Laboratorio de Bacterias Lácticas y Probióticos. Instituto de Agroquímica y Tecnología de Alimentos-CSIC. P.O. Box 73, 46100 Burjassot, Valencia, Spain

Published in Journal of Applied Microbiology (2010) 108(3): 1050-1059 


\section{CAPÍTULO 2}

\section{ABSTRACT}

Aims: To characterize the functionality of the Lactobacillus casei BL23 fbpA gene encoding a putative fibronectin-binding protein

Methods and Results: Adhesion tests showed that L. casei BL23 binds immobilized and soluble fibronectin in a protease sensitive manner. A mutant with inactivated $f b p A$ showed a decrease in binding to immobilized fibronectin and a strong reduction in the surface hydrophobicity as reflected by microbial adhesion to solvents test. However, minor effects were seen on adhesion to the human Caco-2 or HT-29 cell lines. Purified $6 \mathrm{X}(\mathrm{His}) \mathrm{FbpA}$ bound to immobilized fibronectin in a dose-dependent manner. Western blot experiments with FbpA-specific antibodies showed that FbpA could be extracted from the cell surface by $\mathrm{LiCl}$ treatment and that protease digestion of the cells reduced the amount of extracted FbpA. Furthermore, surface exposition of FbpA was detected in other $L$. casei strains by $\mathrm{LiCl}$ extraction and whole-cell ELISA analysis.

Conclusions: FbpA can be found at the L. casei BL23 surface and participates in cell attachment to immobilized fibronectin. We showed that FbpA is an important, but not the only, factor contributing to fibronectin binding in BL23 strain.

Significance and Impact of the Study: This is the first report showing the involvement of FbpA in fibronectin binding in L. casei BL23 and represents a new contribution to the study of attachment factors in probiotic bacteria.

Keywords: Lactobacillus casei, adhesion, fibronectin, extracellular matrix, probiotics 


\section{INTRODUCTION}

Lactobacilli have been used for the fermentation of food products and they have attracted much attention as probiotic bacteria for their beneficial effects on human health.

Adhesion of probiotic bacteria to the host intestinal epithelium is an important criterion for strain selection and several methods (binding to cultured epithelial cells, to immobilized tissue components or to resected tissue) have been employed for characterization and screening of new strains (Tuomola \& Salminen, 1998, Ouwehand, et al., 2001, Styriak, et al., 2003, Vesterlund, et al., 2006). Adhesion is believed not only to play a role in the persistence of a particular strain in the digestive tract but also to participate in pathogen exclusion by competition and blocking of their binding sites at the mucosa (Lee, et al., 2003, Vesterlund, et al., 2006, Collado, et al., 2007). Also, it may contribute to immunomodulation (Galdeano, et al., 2007). However, some authors have hypothesized that attachment factors in lactic acid bacteria are risk factors that might be an indicative of their pathogenic potential (Vesterlund, et al., 2007).

Lactobacilli can bind to mucin, a component of the mucus epithelial layer and to a variety of proteins present in the extracellular matrix (ECM), such as fibronectin, collagen and laminin, which are shed into the mucus or can be exposed to the intestinal lumen in case of trauma, infection or inflammation (Lorca, et al., 2002, Styriak, et al., 2003). While in most cases protein factors have been identified as responsible for this attachment, with the exception of mucin-binding proteins from lactobacilli, information about specific binding proteins is still scarce for this group of microorganisms (Velez, et al., 2007).

Fibronectin is a dimeric 454-kDa glycosylated protein which is present in soluble form in plasma and in immobilized form on the host cells surfaces and in the ECM. 


\section{CAPÍTULO 2}

It is an important target for bacterial attachment in many pathogens, such as Streptococcus pneumoniae and Streptococcus pyogenes, where fibronectin-binding proteins are important pathogenic factors (Molinari, et al., 1997, Holmes, et al., 2001, Jedrzejas, 2007).

There are numerous works describing the attachment of lactic acid bacteria to fibronectin but information about molecules implicated in the mechanism of binding is limited. The surface layer protein (SIpA) from Lactobacillus brevis ATCC8287 is involved in fibronectin binding (de Leeuw, et al., 2006). Moreover, inspection of lactobacilli genome sequences reveals that they carry genes encoding proteins homologous to fibronectin binding proteins from streptococci.

Lactobacillus casei is a species widely used in the dairy industry. It is also a normal constituent of the intestinal microbiota in humans and probiotic capacities have been reported for many strains, for which it is included as a probiotic in food products. Some $L$. casei strains survive the passage through the digestive tract in humans and persist in it for several days (Oozeer, et al., 2006).

In this work we sought to analyze factors involved in interaction with host cells and colonization of intestinal mucosa in $L$. casei BL23. This strain has been widely used for genetic and physiology studies (Acedo-Felix \& Perez-Martinez, 2003), it showed anti-inflammatory effects in animal inflammatory bowel disease models (Foligne, et al., 2007) and its genome sequence is available.

We describe the characterization of a gene encoding a fibronectin-binding protein that was detected during the in silico analysis of putative adhesion factors encoded in the $L$. casei BL23 genome. 


\section{MATERIALS AND METHODS}

\section{Strains and growth conditions}

Lactobacillus casei strains are listed in Table 1 and were grown in MRS broth (BD Difco, Le Pont de Claix, France) at 37으 under static conditions. Escherichia coli $\mathrm{DH} 5 \alpha$ was used for gene cloning and E. coli M15[pREP4] was used for protein purification. Both strains were grown in LB medium under agitation (200 rpm) at $37{ }^{\circ} \mathrm{C}$. Ampicillin and kanamycin were used for E. coli at 100 and $25 \mu \mathrm{g}$ $\mathrm{ml}^{-1}$, respectively. Erythromycin was used for $L$. casei at $5 \mu \mathrm{g} \mathrm{ml}{ }^{-1}$. Solid medium was prepared by adding $1.8 \%$ agar. Bacterial growth curves were determined in microtiter plates (200 $\mu$ l MRS broth per well) at $37^{\circ} \mathrm{C}$ in a Polarstar Omega plate reader (BMG Labtech, Offenburg, Germany).

\section{Construction of an L. casei BL23 fbpA mutant}

A 600-bp internal DNA fragment from the $f b p A$ gene (LCABL_16620) was amplified by PCR using oligonucleotides FBP1 (5'-CTTAAGCTTCGCAGCGTTGTTGC) and FBP2 (5'-TGAGGTACCTGGGCAACGGCATTAC), which introduced HindIII and $K p n l$ restriction sites (underlined), using L. casei BL23 genomic DNA and EcoTaq DNA polymerase (Ecogen, Barcelona, Spain).

The fragment was digested with HindIII and Kpnl and cloned into the integrative vector pRV300 (Leloup, et al., 1997) treated with the same enzymes. The resulting plasmid, pRVfbp, was transformed by electroporation into BL23 strain by using a Gene-Pulser (Biorad) as previously described (Posno, et al., 1991) and transformants were selected in solid media by erythromycin resistance.

Integration at the correct locus and fbpA disruption was checked by southern blot on Hindlll-digested genomic DNA. The probe was the pRVfbp insert labelled with digoxigenin (DIG) with the PCR DIG-labeling mix (Roche). Hybridization and detection was performed in Hybond-N membranes (GE Healthcare) by using alkaline phosphatase-conjugated anti-DIG and the CDP-star chemiluminiscent reagent as recommended by the manufacturer (Roche). 


\section{CAPÍTULO 2}

The insertional mutation was shown to be stable for at least $\sim 40$ generations in the absence of antibiotic (screening of 600 colonies after two consecutive overnight cultures gave a $100 \%$ of erythromycin resistants). Therefore, to discard interferences resulting from growth with antibiotics, bacteria used for the binding experiments in Figure $2 \mathrm{~A}$ and for growth curves were grown in the absence of erythromycin.

Table 1. L. casei strains used in this study

\begin{tabular}{|c|c|c|}
\hline strain & origin/reference & selected characteristics \\
\hline $\mathrm{BL23}$ & CECT $^{*} 5275$ & $\begin{array}{l}\text { laboratory strain; sequenced } \\
\text { genome (Acedo-Felix \& Perez- } \\
\text { Martinez, 2003) }\end{array}$ \\
\hline BL32 & СЕСТ4040 & cheese isolate \\
\hline BL82 & ATCC $^{\dagger} 25598$ & sour milk isolate \\
\hline BL83 & СЕСТ4043 & cheese isolate \\
\hline BL87 & ATCC11578 & oral cavity isolate \\
\hline BL90 & АТСС334 & $\begin{array}{l}\text { cheese isolate; sequenced } \\
\text { genome }\end{array}$ \\
\hline BL91 & ATCC4545 & dental caries isolate \\
\hline BL101 & laboratory stock & $\begin{array}{l}\text { isolated from commercial } \\
\text { probiotic drink }\end{array}$ \\
\hline BL106 & laboratory stock & $\begin{array}{l}\text { isolated from commercial } \\
\text { probiotic drink }\end{array}$ \\
\hline BL193 & laboratory stock & $\begin{array}{l}\text { isolated from commercial } \\
\text { probiotic drink }\end{array}$ \\
\hline BL199 & $\mathrm{CRL}^{\ddagger} 87$ & $\begin{array}{l}\text { exopolysaccharide producer } \\
\text { (Mozzi, et al., 1996) }\end{array}$ \\
\hline BL208 & laboratory stock & human intestinal isolate \\
\hline BL212 & CRL686 & $\begin{array}{l}\text { dry cured sausage isolate } \\
\text { (Fadda, et al., 1998) }\end{array}$ \\
\hline BL227 & laboratory stock & commercial probiotic \\
\hline BL229 & laboratory stock & commercial probiotic \\
\hline BL308 & BL23 fbpA::pRV300, ery & this work \\
\hline
\end{tabular}




\section{Microtitre plate binding assays}

Binding of $L$. casei to immobilized human fibronectin (Sigma) was performed in 96-well Polysorp plates (Nunc) with bacterial cells grown to late exponential phase (OD550 of $3.5-4 ; 1.2 \times 10^{9}$ to $1.4 \times 10^{9}$ cfu $\mathrm{ml}^{-1}$ ).

Plates were covered with $50 \mu \mathrm{g} \mathrm{m}{ }^{-1}$ of fibronectin in carbonate/bicarbonate buffer $50 \mathrm{mmol} \mathrm{I}^{-1} \mathrm{pH} 9.6$ at 4 으 $\mathrm{C}$ overnight. Wells were washed three times with PBS and blocked for $1 \mathrm{~h}$ with PBS plus 1\% Tween 20.

One hundred $\mu$ of each strain were added to each well in PBS adjusted to an OD550nm of $1\left(7 \times 10^{8} \mathrm{cfu} \mathrm{ml}^{-1}\right)$ and plates were incubated overnight at 4 으. After removing non-adhered cells by three washes with $200 \mu \mathrm{l}$ of PBS plus $0.05 \%$ Tween 20 (PBST), the plates were dried and adhered cells were detected by staining with crystal violet ( $1 \mathrm{mg} \mathrm{ml}^{-1}$ for $45 \mathrm{~min}$ ). After washing, the colorant was released with citrate buffer $50 \mathrm{mmol} \mathrm{I}^{-1} \mathrm{pH} 4.0$ (100 $\mu \mathrm{l}$ per well) and the absorbance at $595 \mathrm{~nm}$ was determined in a Multiskan Ascent plate reader (Thermo-Labsystems, Helsinki, Finland).

The effect of protease treatment was assayed by incubating bacterial cells at an OD550nm of $1\left(7 \times 10^{8} \mathrm{cfu} \mathrm{ml}^{-1}\right)$ in PBS with $100 \mu \mathrm{g}$ $\mathrm{ml}^{-1}$ of proteinase $\mathrm{K}$ (Roche) at $37^{\circ} \mathrm{C}$ for $1 \mathrm{~h}$. After incubation, the protease was inactivated by addition of $1 \mathrm{mmol}^{-1}$ phenylmethylsulfonyl fluoride followed by three washes with PBS containing $1 \mathrm{mmol} \mathrm{I}^{-1}$ phenylmethylsulfonyl fluoride. Bacteria were resuspended in PBS to an OD550nm of $1\left(7 \times 10^{8} \mathrm{cfu} \mathrm{ml}^{-1}\right)$ and used for binding assays. Control bacterial cells were treated exactly as digested bacterial cells but without the addition of proteinase $\mathrm{K}$.

Inhibition of binding by soluble fibronectin was assessed by adding different quantities of fibronectin ( 1 to $10 \mu \mathrm{g}$ per well) to the binding assay described above. Blank wells without bound fibronectin were run as controls in all experiments and their absorbance values were subtracted from the values of wells covered with fibronectin. Experiments were carried out in triplicate three times with bacteria coming from independent cultures. 


\section{CAPÍTULO 2}

For whole-cell ELISA analysis, L. casei bacterial cells were bound to immunoplates in PBS buffer at an OD550nm of 0.1 overnight at $4{ }^{\circ} \mathrm{C}$. The wells were washed and blocked with $2 \%$ BSA in PBS and the content of the wells were reacted with a 1:200 dilution of anti-FbpA mouse serum or preimmune serum followed by a 1:1000 dilution of peroxidase-conjugated anti-mouse IgG. Color was developed with the 1-Step ${ }^{\mathrm{TM}}$ Ultra TMB-ELISA substrate (Pierce).

To assay binding to soluble fibronectin, $L$. casei bacterial cells at an OD550nm of $1\left(7 \times 10^{8} \mathrm{cfu} \mathrm{ml}^{-1}\right)$ were incubated with 100 to 500 $\mathrm{ng}$ of fibronectin in $1 \mathrm{ml}$ of PBST containing $1 \%$ BSA for $1 \mathrm{~h}$ at 37으. After three washes with PBST, bound fibronectin was released by boiling the bacteria in SDS-PAGE buffer and detected by western blotting with a rabbit anti-fibronectin serum (Sigma).

\section{Adhesion to solvents test}

Microbial adhesion to solvent (MATS) test has been used to asses the surface properties of lactobacilli (Vinderola, et al., 2004). This test was performed with L. casei essentially as described (BellonFontaine, 1996). Five $\mathrm{ml}$ of overnight cultures of each strain were washed with PBS and resuspended in PBS to a final OD600nm of 0.4 $\left(A_{0}\right)$. This suspension was mixed (1:3) with different solvents (chloroform, ethyl-acetate or hexadecane) and vortexed for $1 \mathrm{~min}$ at full speed. After phase separation, absorbance of the aqueous phase was measured at $600 \mathrm{~nm}\left(A_{1}\right)$. The percentage of adhesion was calculated from: \%Adhesion $=100 \times\left[1-\left(A_{1} / A_{0}\right)\right]$. Each experiment was done in triplicate with bacteria coming from independent cultures. 
Adhesion to Caco-2 and HT-29 cell lines

Epithelial cells were seeded at $4 \times 10^{4}$ cells $\mathrm{cm}^{-2}$ (Caco-2) or $2 \times 10^{5}$ cell $\mathrm{cm}^{-2}$ (HT-29) in 24-well plates in DMEM medium (with Glutamax, glucose $25 \mathrm{mM}$; Gibco) supplemented with $1 \%(\mathrm{v} / \mathrm{v})$ nonessential amino acids solution (Gibco), $1 \%(\mathrm{v} / \mathrm{v})$ sodium pyruvate solution (Gibco), $1 \%(\mathrm{v} / \mathrm{v})$ sodium bicarbonate solution (Gibco, only for HT-29 cells), $1 \%(\mathrm{v} / \mathrm{v})$ of antibiotics $\left(100 \mathrm{U} \mathrm{ml}^{-1}\right.$ penicillin, $100 \mu \mathrm{g}$ $\mathrm{ml}^{-1}$ streptomycin, Gibco) and $10 \%(\mathrm{v} / \mathrm{v})$ fetal calf serum and incubated at $37^{\circ} \mathrm{C}$ in a $\mathrm{CO}_{2}$ incubator.

After the cells reached confluence (incubation for 6 and 3 days for Caco-2 and HT-29, respectively), plates were incubated for additional 15 (Caco-2) or 21 (HT-29) days to allow cell differentiation and the medium was changed every two days.

Log-phase $L$. casei bacterial cells were added to each well in $0.5 \mathrm{ml}$ of culture medium adjusted to an OD550 $\mathrm{nm}$ of $0.2\left(10^{8} \mathrm{cfu} \mathrm{ml}\right.$ $\left.{ }^{1}\right)$ and the plates were incubated for $1 \mathrm{~h}$ at $37^{\circ} \mathrm{C}$ with mild agitation. Non-adhered bacteria were removed by washing 3 times with $1 \mathrm{ml}$ of PBS and the bacteria were detached by covering the monolayer with $200 \mu \mathrm{l}$ of a $15 \%(\mathrm{v} / \mathrm{v})$ solution of trypsin-EDTA (Gibco) in PBS. After addition of $300 \mu \mathrm{l}$ of culture medium, serial dilutions were plated on MRS agar plates and the bacterial colonies were counted after $48 \mathrm{~h}$ of incubation.

The experiments were made in triplicate three times with bacteria coming from independent cultures. Adhesion was expressed as percentage of adhered bacteria respect to input bacteria.

\section{Purification of $6 \mathrm{X}$ (His)FbpA and binding assays}

The $L$. casei BL23 fbpA gene was amplified with oligonucleotides

FBP3 (5'-CGGGGATCCATGTCATTTGACGGAATC) and

FBP4 (5'-ACGAAGCTTTTACTTGGTAGGCGGGTTGC)

which included restriction sites (underlined) and $P f x$ DNA polymerase (Invitrogene).

The amplified fragment was digested with BamHI and HindIII and cloned into the expression vector PQE30 (Qiagen) digested with the same enzymes. 


\section{CAPÍTULO 2}

The plasmid construct was transferred to E. coli M15[pREP4] and cells of the transformed strain were grown in $500 \mathrm{ml}$ of LB medium at $37^{\circ} \mathrm{C}$ until $\mathrm{OD} 550 \mathrm{~nm}$ reached 0.6 . Then, IPTG was added to $1 \mathrm{mmol} \mathrm{I}^{-1}$ and induction was carried out for $3 \mathrm{~h}$ at $37 \circ$. Cells were collected by centrifugation, washed and resuspended in $10 \mathrm{ml}$ of Tris$\mathrm{HCl} 100 \mathrm{mmol} \mathrm{I}^{-1} \mathrm{pH7.4}$, lysozyme $1 \mathrm{mg} \mathrm{ml}^{-1}$, phenylmethylsulfonyl fluoride $0.5 \mathrm{mmol} \mathrm{I}^{-1}$, dithiothreitol $0.5 \mathrm{mmol} \mathrm{I}^{-1}$ and disrupted by sonication. The cellular debris were eliminated by centrifugation at $6000 \times$ for $30 \mathrm{~min}$ at $4{ }^{\circ} \mathrm{C}$, the supernatant containing recombinant 6X(His)FbpA was applied to a Ni-NTA column (Qiagen, $1 \mathrm{ml}$ bed volume) and the recombinant protein purified according to the instructions of the manufacturer.

Fractions containing $6 \mathrm{X}$ (His)FbpA were analyzed by SDS-PAGE and dialyzed overnight at $4{ }^{\circ} \mathrm{C}$ in Tris- $\mathrm{HCl} 50 \mathrm{mmol}^{-1} \mathrm{pH} 8$, EDTA 1 $\mathrm{mmol} \mathrm{I}^{-1}, \mathrm{NaCl} 500 \mathrm{mmol} \mathrm{I}^{-1}$, glycerol $15 \%$ and stored at $-80 \circ \mathrm{C}$ until use. Protein concentrations were determined with the BioRad dyebinding assay.

To test in vitro fibronectin binding of FbpA, different protein amounts of $6 \mathrm{X}$ (His)FbpA were added in $100 \mu \mathrm{l}$ of PBS buffer plus $0.1 \%$ BSA to microwell plates covered with fibronectin or BSA (50 $\mu \mathrm{g} \mathrm{ml}^{-1}$ in carbonate/bicarbonate buffer $50 \mathrm{mmol} \mathrm{I}^{-1} \mathrm{pH} 9.6$, overnight at 4 으). After $1 \mathrm{~h}$ of incubation at 37으, unbound protein was removed by washing 3 times with PBST and His-tagged FbpA was detected with the HisProbe ${ }^{\mathrm{TM}}-\mathrm{HRP}$ reagent (Pierce) and 1-Step ${ }^{\mathrm{TM}}$ Ultra TMB-ELISA (Pierce) as recommended by the manufacturer.

\section{Preparation of antiserum to $6 \mathrm{X}(\mathrm{His}) \mathrm{FbpA}$}

Fifteen micrograms of purified 6X(His)FbpA were intraperitonially administered to 8-weeks old female Balb/c mice (kept at the animal facilities of the University of Valencia) in $50 \mu \mathrm{l}$ of PBS containing adjuvant. Three doses were applied at two weeks intervals. Ten days after the last administration, mice were bled and the presence of anti-FbpA antibodies in sera was tested by Westernblot. 
Isolation of cellular fractions and western blot

L. casei bacterial cells were grown in $50 \mathrm{ml}$ of MRS to late exponential phase (OD550nm of $3.5-4 ; 1.2 \times 10^{9}$ to $1.4 \times 10^{9} \mathrm{cfu} \mathrm{ml}^{-1}$ ) and washed two times with PBS. The pellet was resuspended in Tris$\mathrm{HCl} 10 \mathrm{mmol} \mathrm{l}^{-1} \mathrm{pH} 8, \mathrm{LiCl} 1.5 \mathrm{~mol} \mathrm{I}^{-1}$ and incubated at 4을 for $1 \mathrm{~h}$. Bacteria were pelleted by centrifugation at $6000 \times \mathrm{xg}$ for $10 \mathrm{~min}$ and proteins in the supernatant were precipitated by adding trichloroacetic acid to $10 \%$ and incubation at $4 \% \mathrm{C}$ for $1 \mathrm{~h}$, followed by centrifugation at $10.000 \times \mathrm{xg} 20 \mathrm{~min}$, washing with cold $96 \%$ ethanol and resuspension of the pellet in urea $7 \mathrm{~mol} \mathrm{I}^{-1}$.

The cell pellet was disrupted with glass beads $(0.1 \mathrm{~mm})$ in a Mini-Bead Beater (BioSpec Products, Bartlesville, OK, USA ) with four cycles of $30 \mathrm{~s}$ at maximal speed and unbroken cells were discarded by centrifuging the supernatant three times at $6000 \times \mathrm{xg}$ for $5 \mathrm{~min}$. The supernatant was then centrifuged at $22.000 \mathrm{xg}, 20 \mathrm{~min}$ at $4 \stackrel{\circ}{ } \mathrm{C}$. The soluble fraction was retained as the cytoplasm fraction, whereas the pellet was washed three times at 22.000xg for $15 \mathrm{~min}$ with Tris- $\mathrm{HCl}$ $50 \mathrm{mmol} \mathrm{I}^{-1} \mathrm{pH} 8$ plus $\mathrm{NaCl} 0.5 \mathrm{~mol} \mathrm{l}^{-1}$ and retained as the cellenvelope fraction (cell-wall/membrane fragments).

To asses the effect of protease digestion on $\mathrm{LiCl}$ extraction of $\mathrm{FbpA}$, before extraction the bacteria were treated with protease as described above. Samples of the different fractions were separated by $10 \%$ SDS-PAGE and the gels were electro-transferred to HybondECL membranes (GE Healthcare). FbpA was detected with a mouse anti-FbpA serum (1:5000) and the ECL-advance western blotting detection kit (GE Healthcare).

\section{Statistical analysis.}

Results are indicated as means \pm standard deviation. The significance of the difference of the means in experiments carried out with wild-type $L$. casei and the fbpA mutant was calculated by the Student's t-test with the PRISM 4.0 software (Graph Pad Software, San Diego, CA, USA). 


\section{CAPÍTULO 2}

\section{RESULTS}

\section{Characterization of an L. casei BL23 strain mutated in fbpA}

Inspection of the $L$. casei BL23 genomic sequence (Genbank FM177140) revealed the presence of a gene (LCABL_16620, designated $f b p A$ from now), which encoded a protein showing homology to FBP54 (46\% identity) or PavA (43\% identity) from Streptococcus pyogenes and S. pneumoniae, respectively, two proteins which have been reported to mediate fibronectin binding (Courtney, et al., 1994, Holmes, et al., 2001). The product of fbpA was a 64-kDa protein which contained the typical pfam05833 and pfam05670 domains (Pfam database) present in a variety of bacterial fibronectin-binding proteins.

In order to construct a mutant affected in $f b p A$, an internal fragment of the gene was cloned into the non-replicative plasmid pRV300. Electroporation of this construct (pRVfbp) in BL23 yielded erythromycin-resistant clones in which the plasmid was integrated at the fbpA locus leading to a disruption of the gene (Figure 1). One of such integrants was chosen and designated BL308 fbpA::pRV300).

A

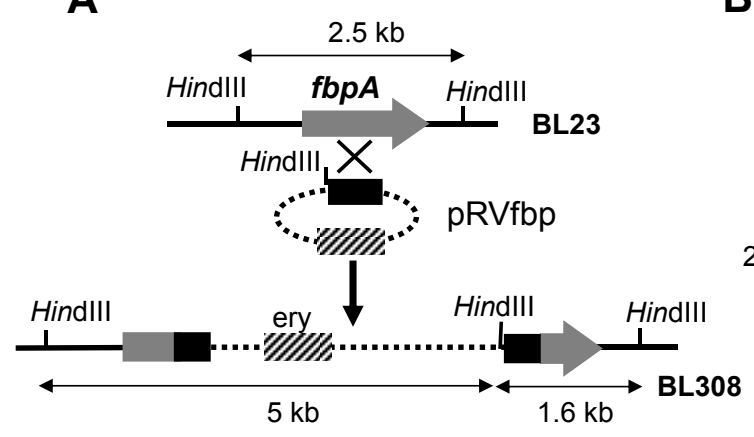

B

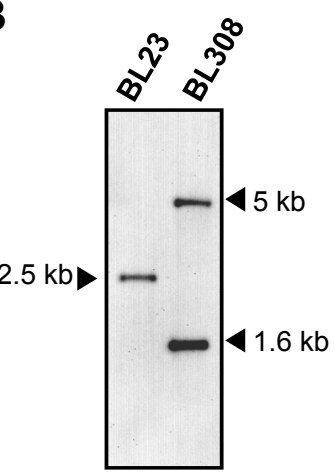

Figure 1. Construction of an L. casei BL23 mutant in fbpA. (A) Wild-type strain was transformed with the non-replicative pRVfbp plasmid and erythromycin-resistant colonies were selected. (B) Integration at the correct locus was verified by southern blot on HindllI-digested genomic DNA from wild-type strain (BL23) and the disrupted mutant (BL308). 
Compared to the wild type, the $f b p A$ mutant showed a reduced specific growth rate $\left(0.320 \pm 0.005\right.$ and $0.290 \pm 0.01 \mathrm{~h}^{-1}$ for $B L 23$ and BL308 strains, respectively; $P=0.0217$ ). Both strains were able to bind fibronectin immobilized on immunoplates in a proteasesensitive manner, as treatment of the cells with proteinase $K$ drastically reduced the binding (Figure 2A). Interestingly, the presence of the $f b p A$ mutation produced a $50 \%$ reduction in binding $(P=0.004)$ to immobilized fibronectin compared to the wild type (Figure 2A).

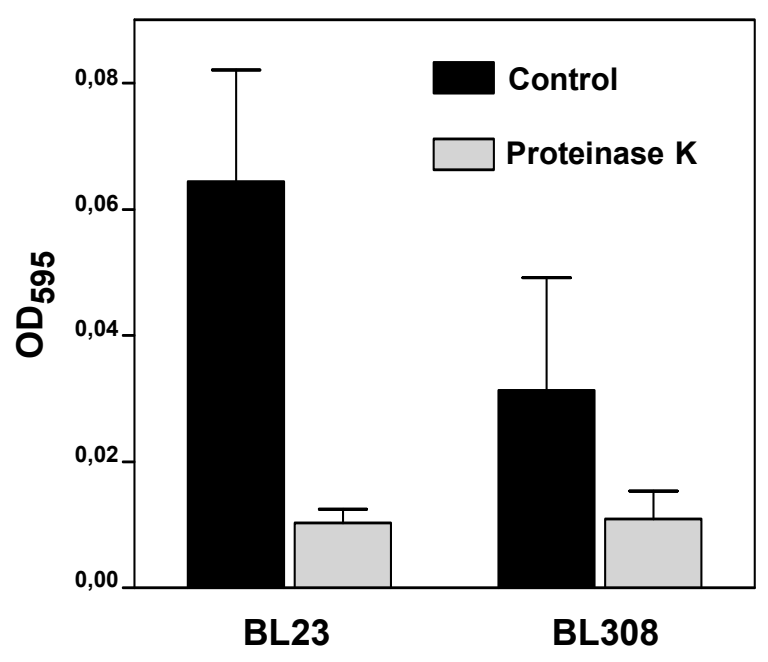

Figure 2A. Binding of $L$. casei to fibronectin. Effect of protease treatment and fbpA disruption on $L$. casei binding to immobilized fibronectin. BL23 is wild-type L. casei; BL308 is the fbpA mutant strain. The bars represent standard deviations.

Adding soluble fibronectin to the binding assays resulted in a decrease of bacterial binding in both the wild type and the fbpA mutant, suggesting that $L$. casei BL23 was interacting with immobilized as well as soluble fibronectin (Figure 2B). 


\section{CAPÍTULO 2}

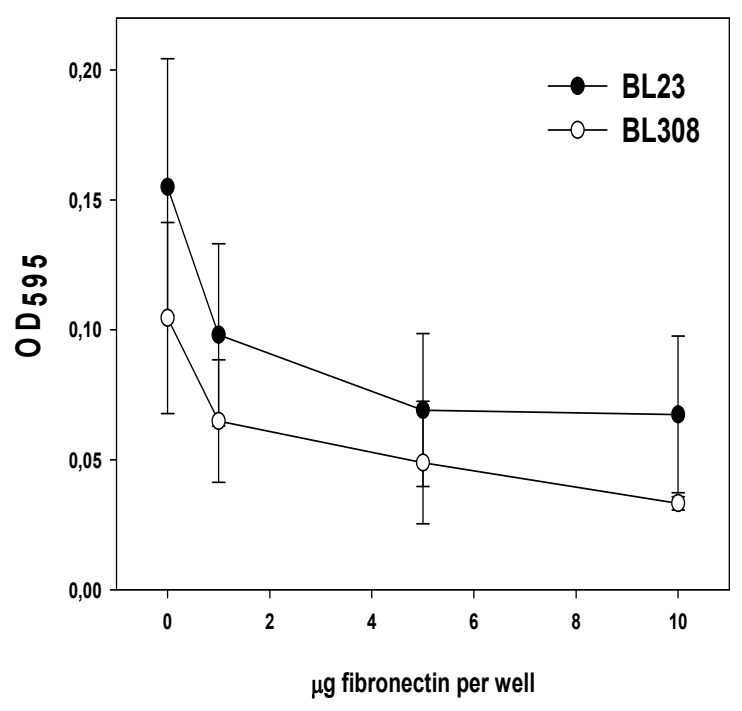

Figure 2B. Inhibition of $L$. casei binding to immobilized fibronectin by soluble added fibronectin. BL23 is wild-type L. casei; BL308 is the fbpA mutant strain. The bars represent standard deviations.

This latter idea was confirmed by incubating L. casei cells with fibronectin. After several washings, fibronectin attached to the cell surface could be released and detected by immunoblotting (Figure $2 \mathrm{C}$ ). In these assays, no differences between the wild-type and the $f b p A$ mutant were observed and protease treatment reduced the binding in both strains (Figure $2 \mathrm{C}$ ). In conclusion, the attachment ability to immobilized as well as soluble fibronectin probably involved surface proteinaceous substances and FbpA played a role in attachment to the immobilized form. 
BL23 BL308

$01002505000100250500 \mathrm{ng}$ fibronectin

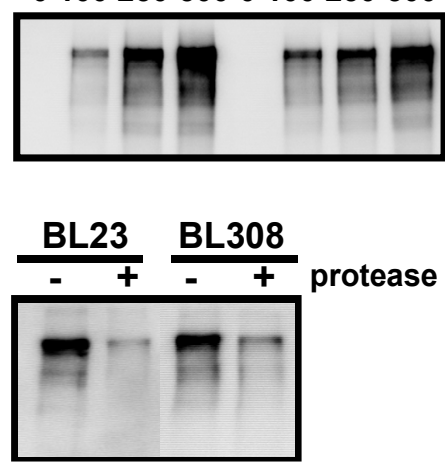

Figure 2C. Binding of $L$. casei to soluble fibronectin. Cells were incubated with fibronectin, washed and bound fibronectin was detected by westernblot. In parallel experiments, cells were treated with protease prior to fibronectin binding assays.

Two other tests were performed in order to detect changes in cell surface characteristics induced by the fbpA mutation.

First, we measured adhesion of the strains to cultured intestinal epithelial cells lines. A small but significant increase in adhesion to the HT-29 cell line was observed in the $f b p A$ mutant strain with respect to the wild type (\% adhesion of $3.03 \pm 0.7$ and $4.11 \pm 1.8$ for the wild type and the fbpA mutant, respectively; $\mathrm{P}=0.02$ ), whereas no significant changes were detected in the binding ability to Caco-2 (\% adhesion of $0.96 \pm 0.6$ and $1.3 \pm 0.34$ for the wild type and the $f b p A$ mutant, respectively; $\mathrm{P}=0.167$ ).

As a second approach we used the microbial adhesion to solvent test (MATS) with three different solvents: chloroform (acidic solvent and electron acceptor); ethyl-acetate (basic solvent and electron donor) and hexadecane (hydrophobic solvent). The results showed that the fbpA mutation did not induce changes in the acidbase characteristics of the cell surface; however, fbpA-disrupted cells showed a clear diminishing in their hydrophobicity, as reflected by a $70 \%$ decrease in the affinity for hexadecane (Figure 3). 


\section{CAPÍTULO 2}

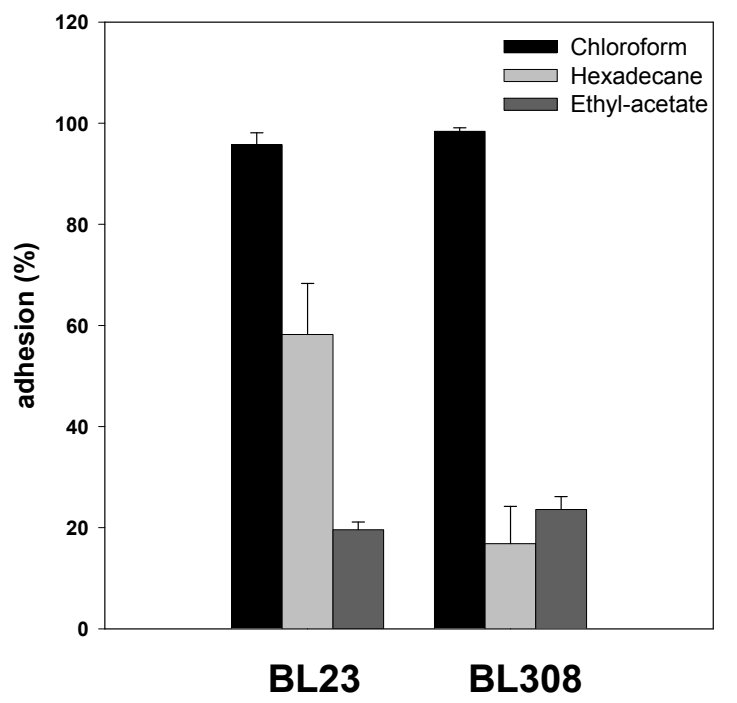

Figure 3. Cell-surface characteristics of $L$. casei wild type (BL23) and the fbpA mutant (BL308) measured by the MATS test. The bars represent standard deviations.

\section{L. casei FbpA binds to fibronectin}

The $f b p A$ gene was cloned in E. coli and FbpA was purified after expression as a His-tagged protein. When the purified protein was tested for binding to fibronectin immobilized on immunoplates, it was shown that $6 \mathrm{X}(\mathrm{His}) \mathrm{FbpA}$ bound to fibronectin in a dosedependent and saturable manner. A low binding was observed when the immunoplates were covered with the control protein BSA (Figure $4 A)$. In inhibition experiments where soluble fibronectin was added to the binding reaction, a low inhibition (around 20\%) in FbpA binding was only found at the highest fibronectin concentration (Figure 4B). 


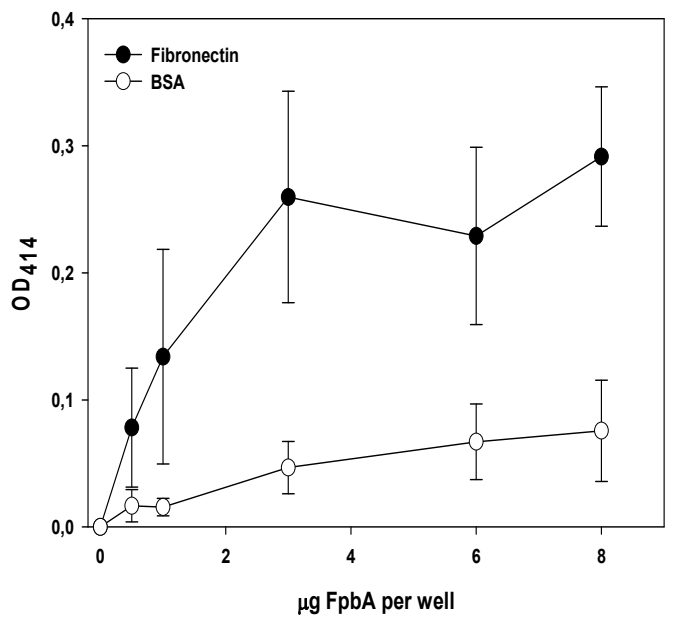

Figure 4A. Binding of purified 6X(His)FbpA to fibronectin immobilized on immunoplates. After washing, the bound protein was detected with a Histag detection reagent. The bars represent standard deviations.

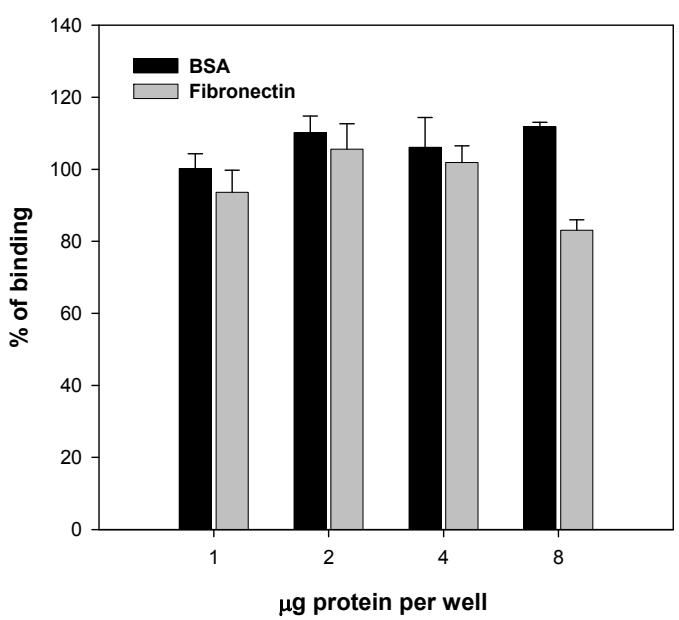

Figure 4B. Inhibitory effect of soluble fibronectin on 6X(His)FbpA binding. The bars represent standard deviations. 


\section{CAPÍTULO 2}

These results were in agreement with the previous characterization of the $L$. casei fbpA mutant and those reported for the S. pneumoniae protein (Holmes, et al., 2001), which showed that FbpA preferentially binds to immobilized fibronectin.

\section{Cellular location of FbpA}

To address the question whether FbpA was present at the $L$. casei cell surface several $L$. casei fractions were tested by western blot against an anti-FbpA serum.

Results showed that a 64-kDa band, the molecular weight of $\mathrm{FbpA}$, was detected in all cellular fractions (surface proteins extracted with $\mathrm{LiCl}$, cell-envelope proteins and cytoplasmic proteins, Figure 5A). Additional unspecific bands were also shown to react with the antiserum. These bands were not detected in the $\mathrm{LiCl}$ fraction, indicating the absence of cross-contamination. The 64-kDa band disappeared in the $f b p A$-disrupted mutant (Figure 5B), thus confirming its identity as FbpA.

Similar amounts of extracted proteins were loaded onto each lane, which led us to the conclusion that most of FbpA was present intracellularly. Treatment of the cells with protease reduced the amount of FbpA extracted by $\mathrm{LiCl}$ treatment, reinforcing the idea that part of FbpA is surface-exposed and accessible to hydrolytic enzymes (Figure 5C). However, similar to the rest of homologue proteins, no signal peptide responsible for protein secretion was identifiable in the FbpA sequence. 
A

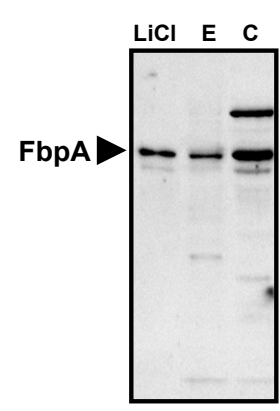

B

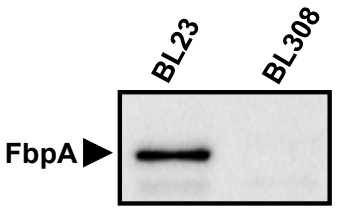

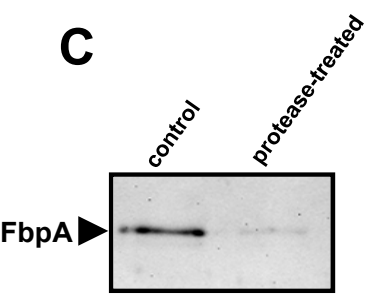

Figure 5. Detection of FbpA at the cell surface. (A) Western blot detection of FbpA in different cellular fractions of $L$. casei wild type (BL23). One $\mu \mathrm{g}$ of extracted proteins was loaded onto each lane. $\mathrm{LiCl}$, surface proteins extracted with $\mathrm{LiCl}$; $\mathrm{E}$, surface proteins from the cell-envelope (cellwall/membrane fraction); C, cytoplasmic proteins; (B) Detection of FbpA in cell extracts ( $1 \mu \mathrm{g}$ total protein per lane) of L. casei BL23 and the fbpA mutant (BL308); (C) The effect of protease digestion on the $\mathrm{LiCl}$ extraction of FbpA from L. casei BL23.

\section{FbpA in other L. casei strains}

We screened a collection of $L$. casei strains from different origins (food and human isolates, including probiotic strains, Table 1) for the presence of FbpA. As expected from the presence of a gene homologous to fbpA in its genome (LSEI_1439), the BL90 (ATCC334) strain showed a reacting protein band similar to BL23 (Figure 5). FbpA homologue proteins were also extracted at different levels by $\mathrm{LiCl}$ treatment in the rest of $L$. casei strains and were also present in the corresponding surface fractions (Figure 6). The cross-reacting bands varied in size, indicating that FbpA from different $L$. casei strains are not totally identical. Furthermore, southern blot hybridization with an $f b p A$ probe showed that a single copy of $f b p A$ was present in all strains (data not shown). 
A

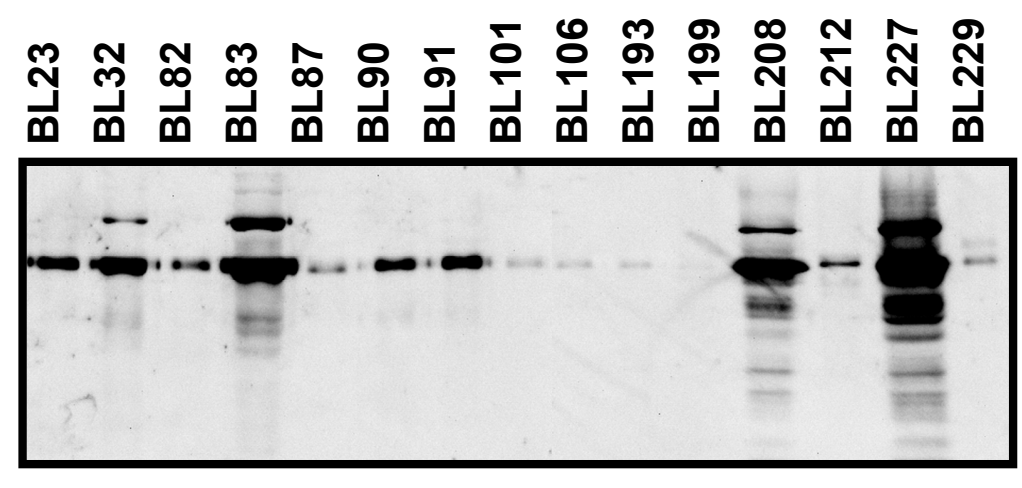

B
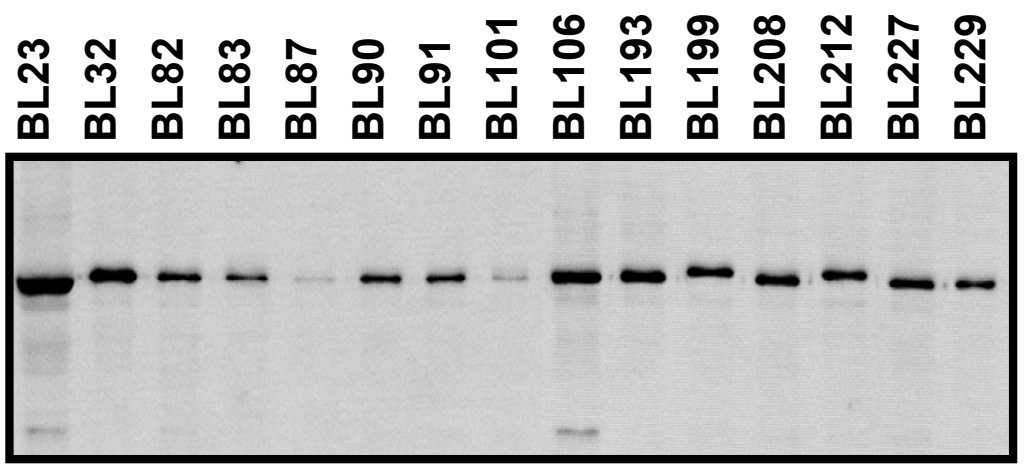

Figure 6. Detection of $\mathrm{FbpA}$ in different L. casei strains. Equal amount of $\mathrm{LiCl}$-extracted proteins (equivalent to the protein extracted from 10 absorbance units (600nm) of cells) (A) and one $\mu$ g of cell-envelope proteins (B) were resolved by $10 \%$ SDS-PAGE and tested by Western-blot with an anti-FbpA serum. 
Whole-cell ELISA analysis, in which the bacterial cells were bound to microtitre plates and probed with the anti-FbpA serum, led also to the detection of FbpA (Figure 7). These results concluded that the presence of FbpA on the cell surface is a common feature in $L$. casei.

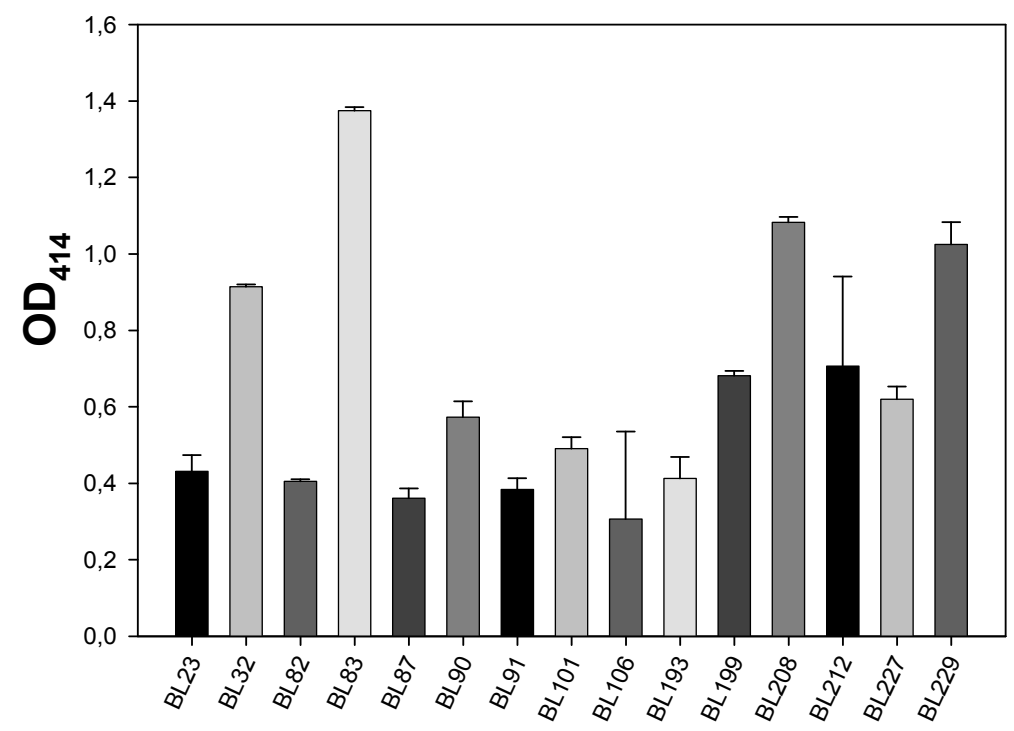

Figure 7. Whole-cell ELISA analysis to detect the presence of FbpA on the surface of $L$. casei strains. Bacterial cells were bound to the surface of immunoplates and an ELISA test was carried out with an anti-FbpA serum. Data presented are subtracted from the absorbance values of control wells incubated with a pre-immune serum. The bars represent standard deviations 


\section{CAPÍTULO 2}

\section{DISCUSSION}

In this work we tried to get some insight into the mechanisms which mediate interactions of lactobacilli to host cells. To this end, we have characterized FbpA from L. casei, a protein homologous to fibronectin-binding proteins described in other bacteria. Genome search at the NCBI database revealed that all sequenced lactobacilli genomes encode FbpA homologues with amino acid identities ranging from 41 to $60 \%$ compared to $L$. casei $\mathrm{FbpA}$.

In the search for host adhesion factors in L. acidophilus NCFB, Buck et al. (Buck, et al., 2005) constructed a mutant in fbpA which displayed a strong reduction in Caco-2 cells attachment. These experiments established that $L$. acidophilus FbpA participates in adhesion to epithelial cells. Nevertheless, no assays on fibronectin binding were carried out in this study.

Contrarily to what was expected, our results showed that, compared to the wild type, L. casei fbpA strain adhered slightly better to HT-29 cells, whereas no significant changes were detected on Caco-2 adherence. This striking result suggests that changes in the bacterial surface resulting from an $f b p A$ mutation (as evidenced by decreased surface hydrophobicity) lead to a slightly improved capacity to attach to HT-29 cell surfaces. However, the reason for this observation is not known. L. casei probably utilizes other FbpAindependent mechanisms for attachment to the HT-29 and Caco-2 cell lines or the contribution of FbpA to binding in these models is low. It has been reported that FBP54, an FbpA homologue from $S$. pyogenes, had minor effects on binding to some types of epithelial cells, whereas binding to others was strongly influenced by this adhesin (Courtney, et al., 1996).

Similar to fbpA-mutated streptococci, where reduction of bacterial fibronectin binding ranged from 50 to $25 \%$ (Christie, et al., 2002, Miller-Torbert, et al., 2008), disruption of L. casei fbpA led to only a $50 \%$ reduction in binding. 
This strengthens the idea that adhesion is a multifactor process and suggests the presence of additional not yet identified fibronectin-binding molecules, presumably of proteinaceous nature. In any case, inspection of the BL23 genome does not reveal the presence of genes encoding other types of fibronectin-binding proteins.

Previous studies showed that some lactobacilli were able to bind to the immobilized but not to the soluble form of fibronectin (Lorca, et al., 2002). We showed that L. casei BL23 can bind both forms of fibronectin but FbpA is binding more efficiently to only the immobilized form.

The FbpA proteins belong to an atypical group of fibronectinbinding proteins which lack the repetitive, secretion and cell-wall anchoring (LPXTG motif) sequences present in other characterized fibronectin-binding proteins (Jedrzejas, 2007). Lack of conventional signal for secretion and anchoring is a common feature of numerous proteins which decorate the bacterial surface. In lactobacilli, many of the characterized attachment factors are surface "moonlighting" proteins that are implicated in other processes. These include the elongation factor Tu (EF-Tu) (Granato, et al., 2004), the heat shock protein GroEL (Bergonzelli, et al., 2006) and glycolytic enzymes (Hurmalainen, et al., 2007, Kinoshita, et al., 2008, Ramiah, et al., 2008). How these proteins are transported and localized at the cell surface is still unknown.

Although L. casei FbpA can be found at the cell surface, the vast majority of the protein was of intracellular location. Similar results were found for the homologue protein Fbp68 from Clostridium difficile (Hennequin, et al., 2003). Despite of the fact that all FbpA-homologues characterized to date have a surface location, posses in vitro binding ability to fibronectin and are important virulence factors in pathogens (Holmes, et al., 2001, Dramsi, et al., 2004), some controversy exists about the exact role of FbpA. 


\section{CAPÍTULO 2}

In S. gordonii, fbpA is clustered with a gene ( $\operatorname{csh} A)$ encoding a distinct fibronectin-binding protein whose expression is downregulated upon $f b p A$ mutation, for which it was postulated that FbpA might play a role in the transcriptional regulation of adhesion factors (Christie, et al., 2002). Likewise, a mutation in fbpA of Listeria monocytogenes reduces the amount of two virulence factors (listeriolysin $O$ and $\operatorname{In|B}$ ) acting at the post-transcriptional level and FbpA co-precipitates with them, therefore it was postulated that it might function as a chaperone or an escort protein for these factors (Dramsi, et al., 2004). The genome context of fbpA in L. casei BL23 does not allow prediction of putative functions for FbpA. The fbpA gene is monocistronic and no adhesion-related genes can be found adjacent to it.

The pleiotropic effects of $f b p A$ mutations largely differ between species. S. pneumoniae pavA (fbpA) mutants bound less to fibronectin and were attenuated in virulence, however, they showed no changes in cell surface physicochemical properties or in the expression of virulence factors (Holmes, et al., 2001). A different situation was found in S. gordonii (Christie, et al., 2002) and in $L$. casei BL23 fbpA mutants, where a clear decrease in the cell surface hydrophobicity was observed. In S. gordonii this decrease was related to the lower expression of CshA (Christie, et al., 2002). Further research is needed to disclose the changes produced by an fbpA mutation on the cell surface of $L$. casei BL23. Whether FbpA directly interacts with fibronectin in vivo or it modulates the expression and functionality of other interacting proteins, or both, is still unknown.

It has been reported that the adhesive capacity of lactobacilli to ECM proteins is not exclusively found in probiotics or human isolates (Vesterlund, et al., 2007). Therefore, no link between attachment and probiotic character appears to exist.

FbpA orthologues are encoded in the genomes of all sequenced lactobacilli and the protein can be extracted from the cell surface of all $L$. casei strains tested in this work, from both human and food origin. 
While the exact role of FbpA in either pathogen, commensal or probiotic bacteria is not yet understood, the study of this protein in lactobacilli may lead to a better understanding of the relations established between these bacteria and the intestinal epithelium.

\section{ACKNOWLEDGEMENTS}

This work was supported by projects AGL2004-00176/ALI and Consolider Fun-c-Food CSD2007-00063 from the Spanish Ministry of Science and Innovation. Diego Muñoz-Provencio was recipient of a pre-doctoral fellowship from the Conselleria de Cultura of the Generalitat Valenciana and of a research fellowship from the Instituto Danone. We thank Dr. Javier Buesa and Rebeca Montava from the Microbiology Department of the University of Valencia for their help in obtaining anti-FbpA antibodies. 


\section{CAPÍTULO 2}

\section{REFERENCES}

Acedo-Felix E \& Perez-Martinez G (2003) Significant differences between Lactobacillus casei subsp. casei ATCC 393T and a commonly used plasmid-cured derivative revealed by a polyphasic study. Int J Syst Evol Microbiol 53: 6775.

Bellon-Fontaine MR, J; vanOss, CJ (1996) Microbial adhesion to solvents: $A$ novel method to determine the electron-donor/electron-

acceptor or Lewis acid-base properties of microbial cells Colloids and Surfaces $B$ : biointerfaces 7: 47-53.

Bergonzelli GE, Granato D, Pridmore RD, Marvin-Guy LF, Donnicola D \& Corthesy-Theulaz IE (2006) GroEL of Lactobacillus johnsonii La1 (NCC 533) is cell surface associated: potential role in interactions with the host and the gastric pathogen Helicobacter pylori. Infect Immun 74: 425-434

Buck BL, Altermann E, Svingerud T \& Klaenhammer TR (2005) Functional analysis of putative adhesion factors in Lactobacillus acidophilus NCFM. Appl Environ Microbiol 71: 8344-8351.

Collado MC, Surono IS, Meriluoto J \& Salminen S (2007) Potential probiotic characteristics of Lactobacillus and Enterococcus strains isolated from traditional dadih fermented milk against pathogen intestinal colonization. J Food Prot 70: 700-705.

Courtney HS, Dale JB \& Hasty DI (1996) Differential effects of the streptococcal fibronectin-binding protein, FBP54, on adhesion of group A streptococci to human buccal cells and HEp-2 tissue culture cells. Infect Immun 64: 2415-2419.

Courtney HS, Li Y, Dale JB \& Hasty DL (1994) Cloning, sequencing, and expression of a fibronectin/fibrinogen-binding protein from group A streptococci. Infect Immun $\mathbf{6 2}$ 3937-3946

Christie J, McNab R \& Jenkinson HF (2002) Expression of fibronectin-binding protein $\mathrm{FbpA}$ modulates adhesion in Streptococcus gordonii. Microbiology 148 : 1615-1625.

de Leeuw E, Li X \& Lu W (2006) Binding characteristics of the Lactobacillus brevis ATCC 8287 surface layer to extracellular matrix proteins. FEMS Microbiol Lett 260: 210-215.

Dramsi S, Bourdichon F, Cabanes D, Lecuit $M$, Fsihi $H$ \& Cossart $P(2004)$ FbpA, a novel multifunctional Listeria monocytogenes virulence factor. Mol Microbiol 53: 639-649.

Fadda S, Vignolo G, Holgado APR \& Oliver G (1998) Proteolytic activity of Lactobacillus strains isolated from dryfermented sausages on muscle sarcoplasmic proteins Meat Sci 49: 11-18.

Foligne B, Nutten S, Grangette C, et al. (2007) Correlation between in vitro and in vivo immunomodulatory properties of lactic acid bacteria. World J Gastroenterol 13: 236-243.

Galdeano CM, de Moreno de LeBlanc A, Vinderola G, Bonet $\mathrm{ME}$ \& 
Perdigon G (2007) Proposed model: mechanisms of immunomodulation induced by probiotic bacteria. Clin Vaccine Immunol 14: 485-492.

Granato D, Bergonzelli GE, Pridmore RD, Marvin L, Rouvet M \& CorthesyTheulaz IE (2004) Cell surfaceassociated elongation factor $\mathrm{Tu}$ mediates the attachment of Lactobacillus johnsonii NCC533 (La1) to human intestinal cells and mucins. Infect Immun 72: 2160-2169.

Hennequin C, Janoir C, Barc MC, Collignon A \& Karjalainen $T$ (2003) Identification

and characterization of a fibronectinbinding protein from Clostridium difficile. Microbiology 149: 27792787.

Holmes AR, McNab R, Millsap KW, Rohde M, Hammerschmidt S, Mawdsley JL \& Jenkinson HF (2001) The pavA gene of Streptococcus pneumoniae encodes a fibronectin-binding protein that is essential for virulence. $\mathrm{Mol}$ Microbiol 41: 1395-1408.

Hurmalainen V, Edelman S, Antikainen J, Baumann M, Lahteenmaki K \& Korhonen TK (2007) Extracellular proteins of Lactobacillus crispatus enhance activation of human plasminogen. Microbiology 153: 1112-1122.

Jedrzejas MJ (2007) Unveiling molecular mechanisms of bacterial surface proteins: Streptococcus pneumoniae as a model organism for structural studies. Cell Mol Life Sci 64: 2799-2822.

Kinoshita $\mathrm{H}$, Uchida $\mathrm{H}$, Kawai $\mathrm{Y}$, et al. (2008) Cell surface Lactobacillus plantarum LA 318 glyceraldehyde-3-phosphate dehydrogenase (GAPDH) adheres to human colonic mucin. J Appl Microbiol 104: 1667-1674.

Lee YK, Puong KY, Ouwehand AC \& Salminen S (2003) Displacement of bacterial pathogens from mucus and Caco-2 cell surface by lactobacilli. J Med Microbiol 52: 925-930.

Leloup L, Ehrlich SD, Zagorec M \& MorelDeville F (1997) Single-crossover integration in the Lactobacillus sake chromosome and insertional inactivation of the ptsl and lacL genes. Appl Environ Microbiol 63: 2117-2123.

Lorca G, Torino MI, Font de Valdez G \& Ljungh AA (2002) Lactobacilli express cell surface proteins which mediate binding of immobilized collagen and fibronectin. FEMS Microbiol Lett 206: 31-37.

Miller-Torbert TA, Sharma S \& Holt RG (2008) Inactivation of a gene for a fibronectin-binding protein of the oral bacterium Streptococcus mutans partially impairs its adherence to fibronectin. Microb Pathog 45: 53-59.

Molinari G, Talay SR, Valentin-Weigand P, Rohde M \& Chhatwal GS (1997) The fibronectin-binding protein of Streptococcus pyogenes, Sfbl, is involved in the internalization of group A streptococci by epithelial cells. Infect Immun 65: 1357-1363.

Mozzi F, Savoy de Giori G, Oliver G \& Font de Valdez G (1996) Exopolysaccharide Production by Lactobacillus casei under Controlled $\mathrm{pH}$. Biotechnol Lett 18: 435-439. 


\section{CAPÍTULO 2}

Oozeer R, Leplingard A, Mater DD, et al. (2006) Survival of Lactobacillus casei in the human digestive tract after consumption of fermented milk. Appl Environ Microbiol 72: 5615-5617.

Ouwehand AC, Tuomola EM, Tolkko S \& Salminen S (2001) Assessment of adhesion properties of novel probiotic strains to human intestinal mucus. Int J Food Microbiol 64: 119-126.

Posno M, Leer RJ, van Luijk N, van Giezen MJ, Heuvelmans PT, Lokman BC \& Pouwels PH (1991) Incompatibility of Lactobacillus Vectors with Replicons Derived from Small Cryptic Lactobacillus Plasmids and Segregational Instability of the Introduced Vectors. Appl Environ Microbiol 57: 1822-1828.

Ramiah K, van Reenen CA \& Dicks LM (2008) Surface-bound proteins of Lactobacillus plantarum 423 that contribute to adhesion of Caco-2 cells and their role in competitive exclusion and displacement of Clostridium sporogenes and Enterococcus faecalis. Res Microbiol 159: 470475 .

Styriak I, Nemcova R, Chang YH \& Ljungh A (2003) Binding of extracellular matrix molecules by probiotic bacteria. Lett Appl Microbiol 37: 329-333.
Tuomola EM \& Salminen SJ (1998) Adhesion of some probiotic and dairy Lactobacillus strains to Caco-2 cell cultures. Int J Food Microbiol 41: 45-51

Velez MP, De Keersmaecker SC \& Vanderleyden J (2007) Adherence factors of Lactobacillus in the human gastrointestinal tract. FEMS Microbiol Lett 276: 140-148.

Vesterlund S, Karp M, Salminen S \& Ouwehand AC (2006) Staphylococcus aureus adheres to human intestinal mucus but can be displaced by certain lactic acid bacteria. Microbiology 152: 1819-1826.

Vesterlund S, Vankerckhoven V, Saxelin M, Goossens H, Salminen S \& Ouwehand AC (2007) Safety assessment of Lactobacillus strains: presence of putative risk factors in faecal, blood and probiotic isolates. Int J Food Microbiol 116: 325-331.

Vinderola CG, Medici M \& Perdigon G (2004) Relationship between interaction sites in the gut, hydrophobicity, mucosal immunomodulating capacities and cell wall protein profiles in indigenous and exogenous bacteria. J Appl Microbiol 96: 230-243. 
CAPÍTULO 3

CAPÍTULO 3 
CAPÍTULO 3 


\section{CAPÍTULO 3}

\section{Shotgun phage display of Lactobacillus casei BL23 against collagen and fibronectin}

Diego Muñoz-Provencio and Vicente Monedero

Laboratorio de Bacterias Lácticas y Probióticos. Instituto de Agroquímica y Tecnología de Alimentos-CSIC. Av. Agustín Escardino 7, 46980 Paterna, Valencia, Spain

Published in Journal of Microbiology and Biotechnology (2011) 21(2):197-203 


\section{CAPÍTULO 3}

\section{ABSTRACT}

Lactobacilli are normal constituents of the intestinal microbiota and some strains show the capacity to bind to extracellular matrix proteins and components of the mucosal layer, which represents an adaptation to persist in this niche.

A shotgun phage-display library of Lactobacillus casei BL23 was constructed and screened for peptides able to bind to fibronectin and collagen. Clones showing binding to these proteins were isolated which encoded overlapping fragments of a putative transcriptional regulator (LCABL_29260), a hypothetical protein exclusively found in the L. casei/rhamnosus group (LCABL_01820) and a putative phage-related endolysin (LCABL_13470).

The construction of different glutathione S-transferase (GST) fusions confirmed the binding activity and demonstrated that the three identified proteins could interact with fibronectin, fibrinogen and collagen.

The results illustrate the utility of phage-display for the isolation of putative adhesins in lactobacilli. However, it remains to be determined whether the primary function of these proteins actually is adhesion to mucosal surfaces.

Keywords: Lactobacillus, probiotic, phage display, extracellular matrix 


\section{INTRODUCTION}

Bacterial adhesion to the intestinal epithelium is an important characteristic to persist in the gastrointestinal tract. In the probiotic field, adhesion has been a classical criterion for strain selection and in the past years and extensive research has been performed in the extracellular biology of probiotic lactobacilli with the aim of identifying surface adhesins (Boekhorst, et al., 2006, Velez, et al., 2007, Sanchez, et al., 2008, Kleerebezem, et al., 2010). However, information about the mechanisms and molecules implicated is still limited for this group of microorganisms.

Many lactobacilli bind to mucin, a component of the mucosal layer, and species of intestinal origin display on their surface specialized mucin-binding proteins (Boekhorst, et al., 2006, von Ossowski, et al., 2010). Lactobacilli also showed ability to bind to extracellular matrix (ECM) proteins like fibronectin, collagen, laminin or fibrinogen (Lorca, et al., 2002, Styriak, et al., 2003, de Leeuw, et al., 2006, Munoz-Provencio, et al., 2009), which normally are not exposed in the mucosal layer but can be of crucial importance in attachment and probiotic activity (displacement and competition to pathogens) under certain circumstances.

The search for adhesins to ECM present in the outer surface of the cell-wall from lactobacilli always led to the isolation of moonlighting proteins implicated in other bacterial processes (Velez, et al., 2007, Sanchez, et al., 2008). As an example, glycolytic enzymes such as enolase (Castaldo, et al., 2009) and glyceraldehyde-3phosphate dehydrogenase (Sanchez, et al., 2009) are displayed in the surface of some lactobacilli and possess binding ability to a variety of ECM proteins. Therefore, the in silico search of putative adhesion factors in lactobacilli becomes a difficult task. 


\section{CAPÍTULO 3}

In the shotgun phage display technique, random DNA fragments of a given organism are fused to a viral capside protein encoding gene to construct a library of phages which express the peptides derived from the DNA sequences on their surfaces (Jacobsson, et al., 2003). This allows the isolation of specific binding peptides after successive rounds of panning and selection of the modified viral particles on a particular target.

This technique has been successfully applied to isolate several adhesins from streptococcal and staphylococcal strains (Bjerketorp, et al., 2002, Jacobsson, 2003, Heilmann, et al., 2004) and, recently, allowed the isolation of a 29 amino acid peptide derived from an $A B C$ transporter from the intestinal probiotic Bifidobacterium longum which interacted with HT-29 epithelial cells (Shkoporov, et al., 2008).

The procedure has the advantage that no prior information on the genomic sequence of the microorganism under study is needed. Furthermore, the identification of interacting peptides within a protein sequence provides valuable information about domains involved in binding.

Lactobacillus casei is a natural inhabitant of the digestive tract and many strains show probiotic effects, for which it is included in a variety of probiotic products. L. casei BL23 is a strain with health promoting effects in animal models (Foligne, et al., 2007, Rochat, et al., 2007, Watterlot, et al., 2010) whose genome has been recently sequenced (Maze, et al., 2010). In this strain, protein-dependent binding to fibronectin and collagen has been reported (MunozProvencio, et al., 2009, Munoz-Provencio, et al., 2010).

In the present work we constructed and screened a shotgun phage-display library of $L$. casei BL23 against collagen and fibronectin and identified peptides derived from proteins of this microorganism which interacted with these ECM proteins. 


\section{MATERIALS AND METHODS}

\section{Strains and growth conditions.}

L. casei BL23 (Acedo-Felix \& Perez-Martinez, 2003, Maze, et al., 2010) was used for chromosomal DNA isolation and it was grown in MRS medium (Difco) at $37^{\circ} \mathrm{C}$ under static conditions. E. coli DH5a was used for gene cloning and E. coli BL21(DE3)[pLysS] was used for protein expression and purification. E. coli TG1 was used as a host for M13 phage propagation. E. coli strains were grown in LB or $2 \times$ TY (16 $\mathrm{g}$ tryptone, $10 \mathrm{~g}$ yeast extract and $5 \mathrm{~g} \mathrm{NaCl}$ per litre) medium at $37^{\circ} \mathrm{C}$ under agitation. Antibiotics used were ampicillin at $100 \mu \mathrm{g} / \mathrm{ml}$, chloramphenicol at $20 \mu \mathrm{g} / \mathrm{ml}$ and kanamycin at $25 \mu \mathrm{g} / \mathrm{ml}$.

\section{Construction and screening of an L. casei BL23 shotgun phage-display library.}

A shotgun phage display library was constructed in the phagemid vector pG8SAET essentially as described (Jacobsson, et al., 2003). L. casei BL23 chromosomal DNA was fragmented by sonication and fragments ranging from 0.1 to $2 \mathrm{~kb}$ were purified from an agarose gel and made blunt with T4 DNA polymerase.

Ten $\mu \mathrm{g}$ of purified fragments were ligated to $10 \mu \mathrm{g}$ of pG8SAET vector previously digested with SnaBI and dephosphorylated with calf intestinal phosphatase. The ligation mixture was electroporated into E. coli TG1 with a Genepulser apparatus (BioRad) following the procedure recommended by the manufacturer.

Transformed cells were resuspended in $50 \mathrm{ml}$ of LB and incubated at $37^{\circ} \mathrm{C}$ for $1 \mathrm{~h}$. The number of transformants was estimated by plating several dilutions on LB agar plates supplemented with ampicillin. Subsequently, ampicillin was added to $100 \mu \mathrm{g} / \mathrm{ml}$ to the cell suspension and after an overnight incubation at $37{ }^{\circ} \mathrm{C}, 2 \mathrm{ml}$ of the culture were infected with helper phage VCSM13 (Stratagene) at a multiplicity of infection of 10 for $30 \mathrm{~min}$ at $37^{\circ} \mathrm{C}$. 


\section{CAPÍTULO 3}

The cell suspension was mixed with $50 \mathrm{ml}$ of melted $2 \times$ TY soft agar (agar $0.5 \% \mathrm{w} / \mathrm{v}$ ) and $5 \mathrm{ml}$ aliquots were poured on $2 \times$ TY plates containing $50 \mu \mathrm{g} / \mathrm{ml}$ ampicillin and $25 \mu \mathrm{g} / \mathrm{ml}$ kanamycin. After an overnight incubation, the soft agar was scrapped off each plate and resuspended in $5 \mathrm{ml}$ of $2 \times \mathrm{TY}$. The mixture from all the plates was pooled and agitated $(100 \mathrm{rpm})$ for $4 \mathrm{~h}$ at room temperature. After centrifugation at $4,000 \times g$ for $20 \mathrm{~min}$ the supernatant was filtered through $0.45 \mu \mathrm{m}$ filters and the medium containing recombinant phages $\left(1.1 \times 10^{12} \mathrm{pfu} / \mathrm{ml}\right)$ was stored in $1 \mathrm{ml}$ aliquots at -80 ․ C.

Polysorp immunotubes ( $75 \times 12 \mathrm{~mm}$, Nunc) or four wells of a 96-well Maxisorp immunoplate (Nunc) were covered with $20 \mu \mathrm{g} / \mathrm{ml}$ fibronectin (human plasma, Sigma) in $50 \mathrm{mM}$ carbonate buffer $(\mathrm{pH}$ 9.6) or $20 \mu \mathrm{g} / \mathrm{ml}$ collagen (type I, Roche) in $10 \mathrm{mM}$ phosphate buffer (pH 5.5), $136 \mathrm{mM} \mathrm{NaCl}$, respectively, at 4으 overnight.

Tubes and plates were washed three times with PBST (PBS plus $0.05 \%$ Tween 20 ) and blocked with PBS plus $0.1 \%$ BSA for $1 \mathrm{~h}$ at room temperature. Phages from the phage display library were added in PBST plus $0.1 \%$ BSA and incubated for $4 \mathrm{~h}$. Unbound phages were removed by washing 25 times with PBST.

Bound phages were eluted by incubation with $1 \mathrm{ml}$ of $50 \mathrm{mM}$ citrate buffer $(\mathrm{pH} \mathrm{4})$ for $10 \mathrm{~min}$. The eluted phages were neutralized with $0.5 \mathrm{ml}$ of $2 \mathrm{M}$ Tris- $\mathrm{HCl}(\mathrm{pH} 8)$ and a $0.75 \mathrm{ml}$ aliquot was used to infect $9.25 \mathrm{ml}$ of an exponentially growing TG1 culture. Several dilutions were plated on $2 \times$ TY plates with $100 \mu \mathrm{g} / \mathrm{ml}$ ampicillin to estimate the number of eluted phages and the cells were concentrated by centrifugation and plated on ten $2 \times$ TY agar plates supplemented with $100 \mu \mathrm{g} / \mathrm{ml}$ ampicillin.

The resulting colonies were scrapped off the plates and infected with VCSM13 helper phage as described above to produce phage particles carrying $\mathrm{pVIII}$ fusions. Phages were recovered from the soft agar and used for further rounds of selection in new fibronectin- and collagen-coated immunotubes and plate wells. 


\section{ELISA of individual clones}

Phages were rescued from several individual clones from the third round of selection and tested for their ability to bind fibronectin, collagen and fibrinogen (fraction I from pig plasma, Sigma).

ELISA plates covered with the substrates at $20 \mu \mathrm{g} / \mathrm{ml}$ were incubated with culture supernatants containing M13 phages carrying pVIII fusions $\left(10^{7} \mathrm{pfu} / \mathrm{ml}\right.$ ) obtained from individual TG1 clones in PBS plus 2\% BSA. Bound M13 clones were detected with a horseradish peroxidase-conjugated anti-M13 antibody according to the instructions of the Detection Module Recombinant Phage Antibody System (GE Healthcare). Plasmid from positive clones was isolated and the inserts sequenced with the oligonucleotide

SAET3 (5'-TTATCAGCTTGCTTTCGAGG).

Homology searches were performed with BLAST at the National Center for Biotechnology Information (http://www.ncbi.nlm.nih.gov) and the sequences were aligned with DNAMAN (Lynnon Corporation)

\section{Protein expression and purification.}

Recombinant proteins were expressed as glutathione Stransferase (GST) fusion proteins from plasmid pGEX2t (GE Healthcare). To this end, $L$. casei genes were amplified by PCR using Platinum Pfx DNA polymerase (Invitrogene) and chromosomal DNA from $L$. casei BL23. The locus LCABL_01820 was amplified with the oligonucleotides:

LCABL_01820For (5'-GGTGGATCCATGGAACACTATGC) and LCABL_01820Rev (5'-CAAGAATTCTCAACTGGCAGTTTC).

Restriction sites introduced for cloning are underlined. The PCR product was digested with $B a m H I$ and EcoRI and cloned into pGEX2t digested with the same enzymes to give a GST-LCABL_01820 fusion. 


\section{CAPÍTULO 3}

Full-length LCABL_29260 (xpkR) was amplified with the oligonucleotides:

DeoRF (5'-GCGAGATCTATGAATAGCATCGA) and

DeoRR2 (5'-GGTGAATTCTTAGACGATCACCTT)

and a fragment encoding the first 88 amino acids of XpkR was amplified with the oligonucleotide pair DeoRF and

DeoRR1 (5'-GCCGAATTCTTAAAGTTTAACTGCATT).

Both PCR products were digested with $B g / I I$ and EcoRI and ligated to pGEX2t digested with BamHI and EcoRI, resulting in plasmids expressing GST-XpkR and GST-XpkR $\mathrm{R}_{1-88}$, respectively. A fragment encoding amino acid 29 to 80 from ps356 was amplified with oligonucleotides:

EndoFor (5'-GTCGGATCCGCCAAGGGTGATCAGGGC) and EndoRev (5'-TGCGAATTCGGCACTAGCAATTTGGCT).

The PCR fragment was digested with BamHI and EcoRI and cloned into pGEX2t to produce a GST-ps356 $29-80$ fusion. The four constructed plasmids were verified by sequencing and transformed into $E$. coli BL21(DE3)[pLysS]. Purification of GST fusion proteins was carried out from $500 \mathrm{ml}$ cultures induced with $1 \mathrm{mM}$ isopropyl- $\beta-D-$ thiogalactopyranoside. The proteins were purified in Glutathione Sepharose 4B columns ( $1 \mathrm{ml}$ bed volume) as recommended by the supplier (GE Healthcare).

\section{In vitro binding assays.}

Proteins were fixed to 96-well Polysorp immunoplates (Nunc) in $50 \mathrm{mM}$ carbonate buffer (pH 9.6) (fibronectin, fibrinogen) or Maxisorp immunoplates (Nunc) in $10 \mathrm{mM}$ phosphate buffer (pH 5.5), $136 \mathrm{mM} \mathrm{NaCl}$ (collagen) at $20 \mu \mathrm{g} / \mathrm{ml}(100 \mu \mathrm{l} /$ well) overnight at 4 으.

Plates were washed three times with PBS and blocked with PBS containing $2 \%$ BSA for 2 hours at 37으. After washing three times with PBS the different GST-fusions (GST-ps356 $29-80$, GST-XpkR 1-88 $_{1}$ , GST-XpkR and GST-LCABL_01820) were added (10 $\mu \mathrm{g}$ in $100 \mu \mathrm{l}$ of PBS) and plates were incubated overnight at $4{ }^{\circ} \mathrm{C}$. 
Plates were washed four times with PBS and GST activity was detected with $100 \mu \mathrm{l} /$ well of a solution containing $100 \mathrm{mM}$ phosphate buffer ( $\mathrm{pH}$ 6.5), $1 \mathrm{mM}$ 1-chloro-2,4-dinitrobenzene, $1 \mathrm{mM}$ reduced glutathione, by measuring changes in the absorbance at $340 \mathrm{~nm}$ over a $1 \mathrm{~h}$ period in an Multiskan Ascent plate reader (Thermo-Labsystems).

\section{RT-PCR}

Total RNA was isolated from $10 \mathrm{ml}$ of exponentially growing L. casei BL23 cells (OD550nm of 0.9) using the Trizol reagent as recommended by the supplier (Invitrogen). The RNA was treated with RNAase-free DNase I (Turbo DNA-free kit, Ambion) and $2 \mu \mathrm{g}$ were used to synthesize cDNA with the Superscript VILO cDNA synthesis kit as recommended by the manufacturer (Invitrogen).

RNA (60 ng), cDNA (5 ng) and chromosomal DNA samples (100 ng) were used to amplify fragments from $x p k R$, LCABL_01820 and ps356 with the oligonucleotide pairs DeoRF/DeoRR1, LCABL_01820For/LCABL_01820Rev and EndoFor/EndoRev, respectively, and the reaction products were separated in $1.5 \%$ agarose gels stained with ethidium bromide. 


\section{CAPÍTULO 3}

\section{RESULTS}

Identification of $L$. casei peptides interacting with collagen and fibronectin by phage display

An L. casei BL23 phage display library was constructed in the vector pG8SAET (Jacobsson, et al., 2003). The library consisted in $1.2 \times 10^{7}$ independent clones with random BL23 chromosomal fragments fused to the $5^{\prime}$ end of the phage coat protein VIII gene.

After three rounds of panning on collagen, overlapping clones spanning two different genes (LCABL_29260 and LCABL_01820, Figure 1A) were obtained. Panning of the library on fibronectin resulted in the isolation of clones derived also from LCABL_29260 and of a new gene (LCABL_13470; Figure 1A). The isolation of different overlapping clones confirmed that binding was due to a specific interaction with the displayed peptides.

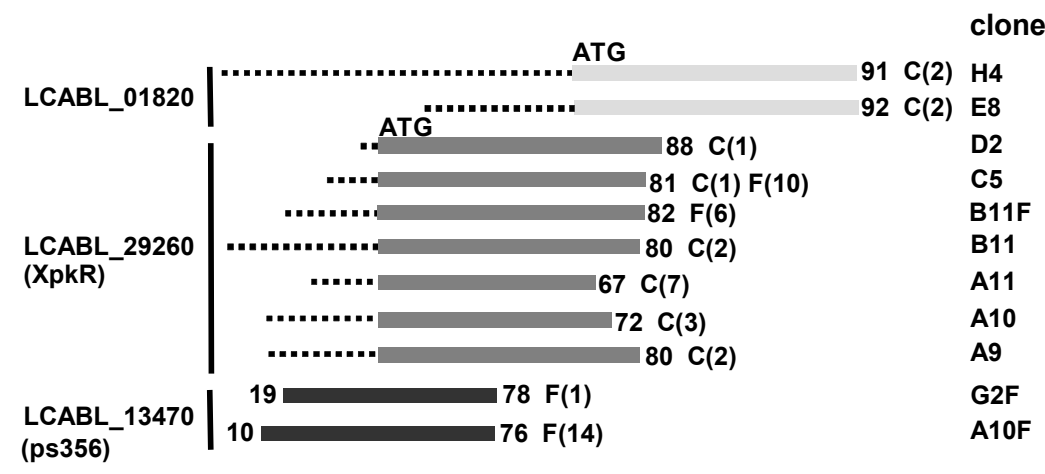

Figure 1A. Binding clones isolated by phage display. Schematic representation of the DNA fragments present in each clone. Rectangles represent the length of each open reading frame and numbers indicate the encoded amino acid positions that were fused to the pVIII M13 protein. Dotted lines represent the $L$. casei BL23 5 ' non-coding sequences upstream the open reading frame in each clones. $\mathrm{C}$ means that the clones were isolated on collagen, whereas $F$ means that the clones were isolated after panning on fibronectin. Numbers in parenthesis indicate the number of times that a particular fragment was isolated. The clone column shows the designations of the representative clones chosen for further analysis. 
Figure $1 \mathrm{~B}$ shows an ELISA experiment with representative M13 clones carrying each pVIII fusion. In these experiments, BSA and fibrinogen were used as controls. No clone was able to bind BSA. On the contrary, in addition to fibronectin, the clones carrying LCABL_13470 fragments were also able to bind fibrinogen.

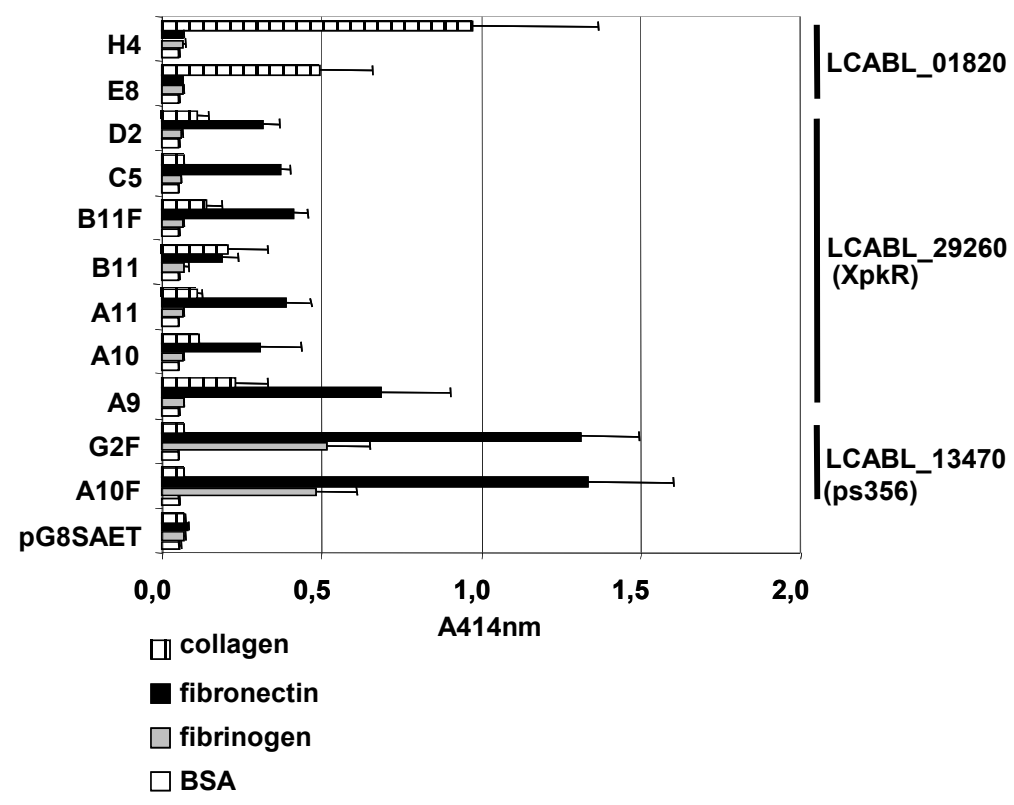

Figure 1B. ELISA analysis for binding to ECM proteins of representative M13 clones carrying different $\mathrm{pVIII}$ fusions. Results are derived from two independent experiments repeated in quadruplicate. Error bars are standard deviations.

Fragments from LCABL_29260 and LCABL_01820 always carried segments corresponding to the $5^{\prime}$ region of the genes and therefore LCABL_29260- and LCABL_01820-pVIII fusion proteins were translated from the $L$. casei translational signals present in these segments. For LCABL_13470, the pVIII fusions were expressed from the signals carried by pG8SAET (Jacobsson, et al., 2003). 


\section{CAPÍTULO 3}

LCABL_29260 coded for a putative transcriptional regulator of the DeoR family. This family of regulators carry an N-terminal helix-turn-helix (H-T-H) DNA-binding domain and are usually controlling expression of genes related to sugar catabolism. This gene was located upstream of a gene encoding a putative phosphoketolase enzyme ( $x p k$ ), with homology to phosphoketolase-2 (xpk2) from Lactobacillus plantarum (79\% identity), an enzyme which displayed catalytic activity on xylulose-5-phosphate and fructose-6phosphate (Yevenes \& Frey, 2008).

The same genetic arrangement was observed in L. plantarum, Lactobacillus salivarius and Lactobacillus sakei strains, for which the LCABL_29260 product was tentatively named XpkR. The $x p k R$ clones encoded amino acids of the $\mathrm{N}$-terminal part of the protein, indicating that the binding ability resided at the putative $\mathrm{H}-\mathrm{T}-\mathrm{H}$ motif present in this region.

LCABL_01820 encoded a putative $12 \mathrm{kDa}, 101$ amino acid protein with no evident secretion signal and for which homologues were only found in L. casei (ATCC334 and ATCC 25302; 100\% identity) and Lactobacillus rhamnosus strains (GG, HN001, Lc705 and LMS2-1; 91\% identity). Sequence analysis showed that the practical totality of the LCABL_01820 open reading frame (91 and 92 amino acids, Figure $1 A)$ was fused to the $p V I I I$ gene.

LCABL_13470 was similar (46\% identity) to the ps356 endolysin from Lactococcus lactis (Wegmann, et al., 2007) and was annotated as a ps356-like protein in the L. casei BL23 genome. It consisted in a putative phage-related endolysin that contained LysM and SH3 domains, probably involved in cell-wall binding, in addition to a catalytic domain belonging to the glycosyl hydrolase family 25 (residues 36 to 214 , endo- $N$-acetylmuramidase). A secretion signal peptide was predicted in the $L$. casei ps356 sequence with a likely cleavage site between positions 28 and 29 (SignalP 3.0 server, http://www.cbs.dtu.dk/services/SignalP/). Homologues to ps356 were also present in other lactobacilli belonging to the $L$. casei/rhamnosus group with amino acid identities ranging from 63 to $92 \%$. 
L. casei ps356 was encoded within a prophage gene cluster (LCABL_12880 to LCABL_13480) with a typical structural organization containing putative lysogeny, replication, structural and lysis modules resembling the structure of $L$. casei phages Lca1, A2 and Lrm1. Analysis of the cloned fragments revealed that the binding activity (amino acids 19 to 76 ) was located at the $\mathrm{N}$-terminal catalytic domain (Figure 1A).

\section{Ability of purified XpkR, ps356 and LCABL_01820 to bind collagen and fibronectin.}

In order to test if the binding ability of the identified peptides was independent of their presence at the M13 surface; several GST fusions were constructed and purified (Figure 2). For LCABL_01820, the whole 101 amino acid protein was fused to GST, while for XpkR two variants were constructed. The first one carried 88 amino acids from the $\mathrm{N}$-terminus, whereas a second fusion carried the full-length protein. Finally, amino acids 29 to 80 from the ps356 N-terminus (excluding the signal peptide) were fused to GST.

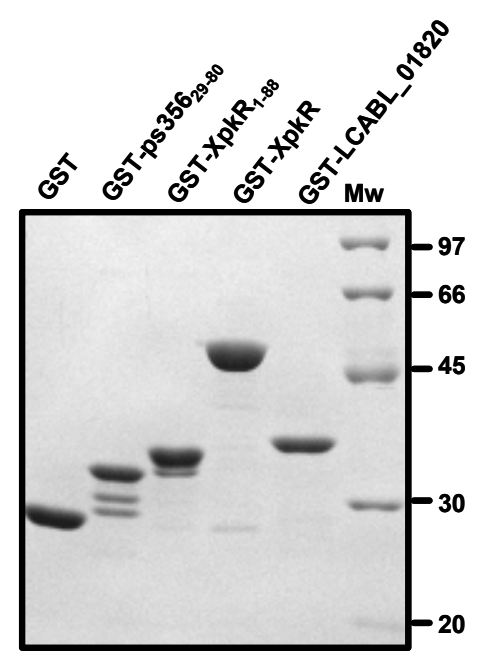

Figure 2. Analysis of purified GST fusions carrying different amino acid segments of XpkR, ps356 and LCABL_01820 in a $12 \%$ SDS-PAGE gel. Numbers written as suffix in XpkR and ps356 indicate the position numbers of the amino acids present in the fusions. When no numbers are indicated, the full-length protein is fused. Numbers on the right are the molecular weights $(\mathrm{Mw})$ of a protein marker in kDa. 


\section{CAPÍTULO 3}

The results presented in Figure 3 demonstrate that the purified proteins retained their ability to bind to the assayed ECM proteins. Surprisingly, the three identified proteins were able to bind the three substrates to some extent. Similar to ELISA results with M13 phages, the product of LCABL_01820 had the maximum binding capacity to collagen but it also showed the maximum level of binding to fibrinogen, even if no fibrinogen binding was detected when the peptide was located at the M13 surface (Figure 1B). For XpkR, fusion of the whole protein to GST resulted in a loss of the binding capacity to collagen, suggesting that the N-terminal fusion of GST might be hampering the interaction of the $\mathrm{N}$-terminus of $\mathrm{XpkR}$ with this protein. The activity determined with the GST control was low and at the level of the background obtained in wells were no protein was added, indicating that GST alone had no binding capacity.

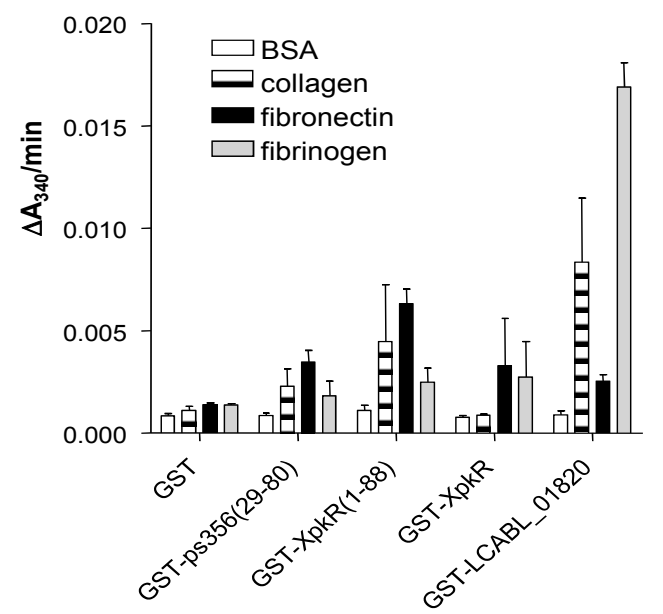

Figure 3. Binding of GST fusions to different ECM proteins. After incubation of the different GST fusions in immunoplates covered with ECM proteins, unbound GST fusions were washed and bound proteins were detected by measuring GST activity spectrophotometrically with a coupled reaction at $340 \mathrm{~nm}$. Data are expressed as increment of the A340nm per minute. Results are from two independent experiments repeated in quadruplicate. Error bars represent standard deviations. 
Expression of $x p k R, p s 356$ and LCABL_01820 in L. casei BL23.

In order to determine whether $x p k R, p s 356$ and LCABL_01820 genes were expressed in $L$ casei $B L 23$ under our laboratory conditions we examined their transcription by RT-PCR analysis. These experiments evidenced the presence of RNA transcripts for the three open reading frames (Figure 4).

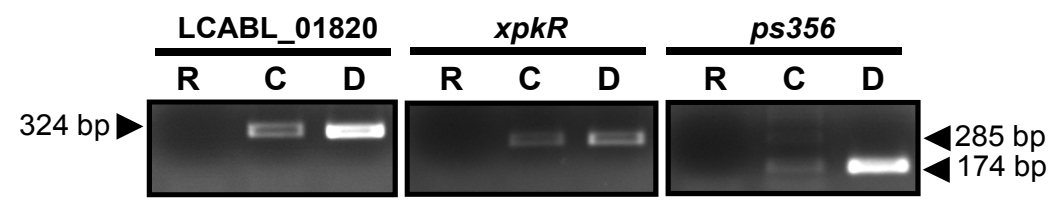

Figure 4. RT-PCR analysis of the expression of LCABL_01820, $x p k R$ and $p s 356$ in L. casei BL23. PCR was performed with RNA samples (lanes R); cDNA samples (lanes C) and chromosomal DNA (lanes D) as template. 


\section{CAPÍTULO 3}

DISCUSSION

Exoproteome analysis of lactobacilli shows that, analogous to other bacteria, these microorganisms present at their surfaces a variety of proteins with non evident secretion signal involved in processes such as central metabolism, protein folding, stress response and transcription and translation (Beck, et al., 2009, Sanchez, et al., 2009). In some cases, these surface proteins are involved in the interaction with the host mucosa and behaved as sticky factors able to interact with the mucosal layer (Sanchez, et al., 2009) or to activate defined host pathways (Antikainen, et al., 2007)

In this work, the use of the phage display technique led to the isolation of three proteins from $L$ casei BL23 with in vitro binding activity to ECM proteins. With the exception of the ps356 endolysin, the identified proteins lacked recognized secretion signals. The isolation of a protein with putative cell-wall hydrolytic activity is not surprising as many endolysins from bacterial pathogens have been reported to bind to the ECM and act as attachment factors involved in virulence (Teng, et al., 2003, Heilmann, et al., 2005). The ps356 gene was located within a prophage cluster and detection of its transcription by RT-PCR evidenced that it was not a silent gene. This is not an anomalous situation, as mobilization of other prophage in a portion of BL23 bacterial population has been detected by massive sequencing (Maze, et al., 2010).

The second identified protein, XpkR, is probably the transcriptional regulator of a gene ( $x p k$ ) encoding an enzyme of the pentose metabolism (Yevenes \& Frey, 2008). Surface location of other transcriptional regulators have been described when analyzing the surface proteome of some microorganisms (Schaumburg, et al., 2004, Hansmeier, et al., 2006), but the functionality of this location is unknown. The binding domain of XpkR resided at the $\mathrm{N}$-terminal DNA binding region and the presence of the $C$-terminal part of $X p k R$ in the GST-XpkR fusion was hindering this domain to interact with collagen, but not with fibronectin or fibrinogen. This suggests that the spatial requirements for binding each substrate are different. 
The third protein, the product of LCABL_01820, is a hypothetical protein with unknown function exclusively found in the L. casei/rhamnosus group. It showed a strong binding activity but its specificity was dependent on the type of fusion employed in the assays. In analogy to the results with $X p k R$, fusion of the product of LCABL_01820 to M13 pVIII prevented the binding of this protein to fibronectin and fibrinogen, whereas a GST-LCABL_01820 fusion interacted with the three assayed substrates. In this sense, ps356 and LCABL_01820 clones were only isolated after panning on fibronectin and collagen, respectively, whereas the three identified proteins were able to attach to fibronectin, collagen and fibrinogen.

Lack of a strict binding specificity is a characteristic of others attachment factors in lactobacilli. As an example, the surface layer protein (SIpA) from Lactobacillus brevis ATCC 8287 was shown to interact with laminin, collagen, fibronectin and fibrinogen (de Leeuw, et al., 2006) and a solute-binding protein from an $A B C$ transporter in Lactobacillus reuteri ( $\mathrm{CnBP}$ ) and Lactobacillus mucosae (Lam29), binds collagen, mucus, Caco-2 cells and blood antigens (Miyoshi, et al., 2006, Watanabe, et al., 2010). This points to the idea that lactobacilli decorate their surface with non-specific interacting proteins able to bind a broad spectrum of targets. However, it is not known at this stage whether the identified proteins participate in $L$. casei $\mathrm{BL} 23$ binding to ECM proteins.

The protein FbpA of $L$. casei BL23 has been recently described as possessing fibronectin binding activity (Munoz-Provencio, et al., 2010). This protein was not identified during our phage display screening. This could arise from one of the disadvantages of this technique: the interacting motifs are fused to a M13 coat protein, which may affect phage viability and restricts the size of the displayed peptides (Jacobsson, et al., 2003). Similarly, no fragments from enolase or glyceraldehyde-3-phosphate dehydrogenase enzymes were isolated, even though these proteins from $L$. casei BL23 show binding activity to collagen and fibronectin (our unpublished observations). 


\section{CAPÍTULO 3}

This limits the use of phage display to the isolation of proteins with defined, not very large interacting domains which show strong binding.

In conclusion, we have constructed a highly represented $L$. casei BL23 phage display library that can be useful to study interactions of this microorganism to host factors. Among the three identified proteins, we have characterized the product of a previous hypothetical gene (LCABL_01820) as a protein with binding capacity to ECM proteins. The length of the interacting domain (about 91 amino acids) and its binding characteristics open the possibility for its biotechnological application in lactobacilli for enhancement of ECM binding. Further genetic/biochemical analyses are required to assess the role of the identified proteins in L. casei interaction with the host.

\section{ACKNOWLEDGEMENTS}

We are grateful to Dr. Lars Frykberg for the generous gift of plasmid pG8SAET. This work was supported by projects AGL2004-00176/ALI and Consolider Fun-c-Food CSD2007-00063 from the Spanish Ministry of Science and Innovation. Diego Muñoz-Provencio was recipient of a research fellowship from the Instituto Danone. We thank Dr. Manuel Zúñiga for critical reading. 


\section{REFERENCES}

Acedo-Felix E \& Perez-Martinez G (2003) Significant differences between Lactobacillus casei subsp. casei ATCC 393T and a commonly used plasmid-cured derivative revealed by a polyphasic study. Int J Syst Evol Microbiol 53: 6775.

Antikainen J, Kuparinen V, Lahteenmaki K \& Korhonen TK (2007) Enolases from Gram-positive bacterial pathogens and commensal lactobacilli share functional similarity in virulence-associated traits. FEMS Immunol Med Microbiol 51: 526-534.

Beck HC, Madsen SM, Glenting J, et al. (2009) Proteomic analysis of cell surface-associated proteins from probiotic Lactobacillus plantarum. FEMS Microbiol Lett 297: 61-66.

Bjerketorp J, Nilsson M, Ljungh A, Flock JI, Jacobsson K \& Frykberg L (2002) A novel von Willebrand factor binding protein expressed by Staphylococcus aureus. Microbiology 148: 2037-2044.

Boekhorst J, Wels M, Kleerebezem M \& Siezen RJ (2006) The predicted secretome of Lactobacillus plantarum WCFS1 sheds light on interactions with its environment. Microbiology 152: 3175-3183.

Boekhorst J, Helmer Q, Kleerebezem M \& Siezen RJ (2006) Comparative analysis of proteins with a mucus-binding domain found exclusively in lactic acid bacteria. Microbiology 152: 273-280.
Castaldo C, Vastano V, Siciliano RA, et al (2009) Surface displaced alfaenolase of Lactobacillus plantarum is a fibronectin binding protein. Microb Cell Fact 8: 14.

de Leeuw E, Li X \& Lu W (2006) Binding characteristics of the Lactobacillus brevis ATCC 8287 surface layer to extracellular matrix proteins. FEMS Microbiol Lett 260: 210-215.

Foligne B, Nutten S, Grangette C, et al. (2007) Correlation between in vitro and in vivo immunomodulatory properties of lactic acid bacteria. World J Gastroenterol 13: 236-243.

Hansmeier N, Chao TC, Kalinowski J, Puhler A \& Tauch A (2006) Mapping and comprehensive analysis of the extracellular and cell surface proteome of the human pathogen Corynebacterium diphtheriae. Proteomics 6: 2465-2476.

Heilmann C, Hartleib J, Hussain MS \& Peters G (2005) The multifunctional Staphylococcus aureus autolysin aaa mediates adherence to immobilized fibrinogen and fibronectin. Infect Immun 73: 4793-4802.

Heilmann C, Niemann S, Sinha B, Herrmann M, Kehrel BE \& Peters G (2004) Staphylococcus aureus fibronectin-binding protein (FnBP)-mediated adherence to platelets, and aggregation of platelets induced by FnBPA but not by FnBPB. J Infect Dis 190: 321-329.

Jacobsson K (2003) A novel family of fibrinogen-binding proteins in Streptococcus agalactiae. Vet Microbiol 96: 103-113. 


\section{CAPÍTULO 3}

Jacobsson K, Rosander A, Bjerketorp J \& Frykberg $L$ (2003) Shotgun Phage Display - Selection for Bacterial Receptins or other Exported Proteins. Biol Proced Online 5: 123-135.

Kleerebezem M, Hols $\mathrm{P}$, Bernard E, Rolain $\mathrm{T}$, Zhou M, Siezen RJ \& Bron PA (2010) The extracellular biology of the lactobacilli. FEMS Microbiol Rev 34: 199-230.

Lorca G, Torino MI, Font de Valdez G \& Ljungh AA (2002) Lactobacilli express cell surface proteins which mediate binding of immobilized collagen and fibronectin. FEMS Microbiol Lett 206: 31-37.

Maze A, Boel G, Zuniga M, et al. (2010) Complete genome sequence of the probiotic Lactobacillus casei strain BL23. J Bacteriol 192: 2647-2648.

Miyoshi Y, Okada S, Uchimura T \& Satoh E (2006) A mucus adhesion promoting protein, MapA, mediates the adhesion of Lactobacillus reuteri to Caco-2 human intestinal epithelial cells. Biosci Biotechnol Biochem 70: 1622-1628.

Munoz-Provencio D, Perez-Martinez G \& Monedero V (2010) Characterization of a fibronectinbinding protein from Lactobacillus casei BL23. J Appl Microbiol 108: 1050-1059.

Munoz-Provencio D, Llopis $M$, Antolin $M$, de Torres I, Guarner F, PerezMartinez G \& Monedero $V$ (2009) Adhesion properties of Lactobacillus casei strains to resected intestinal fragments and components of the extracellular matrix. Arch Microbiol 191: 153-161.
Rochat T, Bermudez-Humaran L, Gratadoux JJ, Fourage C, Hoebler C, Corthier G \& Langella P (2007) Anti-inflammatory effects of Lactobacillus casei BL23 producing or not a manganesedependant catalase on DSSinduced colitis in mice. Microb Cell Fact 6: 22.

Sanchez B, Bressollier P \& Urdaci MC (2008) Exported proteins in probiotic bacteria: adhesion to intestinal surfaces, host immunomodulation and molecular cross-talking with the host. FEMS Immunol Med Microbiol 54: 1-17.

Sanchez B, Schmitter JM \& Urdaci MC (2009) Identification of novel proteins secreted by Lactobacillus plantarum that bind to mucin and fibronectin. J Mol Microbiol Biotechnol 17: 158-162.

Schaumburg J, Diekmann O, Hagendorff P, et al. (2004) The cell wall subproteome of Listeria monocytogenes. Proteomics 4: 2991-3006.

Shkoporov AN, Khokhlova EV, Kafarskaia LI, Pavlov KA, Smeianov VV, Steele JL \& Efimov BA (2008) Search for protein adhesin gene in Bifidobacterium longum genome using surface phage display technology. Bull Exp Biol Med 146: 782-785.

Styriak I, Nemcova R, Chang YH \& Ljungh A (2003) Binding of extracellular matrix molecules by probiotic bacteria. Lett Appl Microbiol 37: 329-333.

Teng $F$, Kawalec $M$, Weinstock GM, Hryniewicz W \& Murray BE (2003) An Enterococcus faecium secreted antigen, SagA, exhibits 
broad-spectrum binding to extracellular matrix proteins and appears essential for E. faecium growth. Infect Immun 71: 50335041.

Velez MP, De Keersmaecker SC \& Vanderleyden J (2007) Adherence factors of Lactobacillus in the human gastrointestinal tract. FEMS Microbiol Lett 276: 140-148.

von Ossowski I, Reunanen J, Satokari R, et al. (2010) Mucosal adhesion properties of the probiotic Lactobacillus rhamnosus GG SpaCBA and SpaFED pilin subunits. Appl Environ Microbiol 76: 2049-2057.

Watanabe $M$, Kinoshita $H$, Nitta $M$, et al. (2010) Identification of a new adhesin-like protein from Lactobacillus mucosae ME-340 with specific affinity to the human blood group A and B antigens. J Appl Microbiol.

Watterlot L, Rochat $\mathrm{T}$, Sokol $\mathrm{H}$, et al. (2010) Intragastric administration of a superoxide dismutase-producing recombinant Lactobacillus casei BL23 strain attenuates DSS colitis in mice. Int J Food Microbiol.

Wegmann $\mathrm{U}, \mathrm{O}^{\prime}$ Connell-Motherway $\mathrm{M}$, Zomer A, et al. (2007) Complete genome sequence of the prototype lactic acid bacterium Lactococcus lactis subsp. cremoris MG1363. I Bacteriol 189: 3256-3270.

Yevenes A \& Frey PA (2008) Cloning, expression, purification, cofactor requirements, and steady state kinetics of phosphoketolase-2 from Lactobacillus plantarum. Bioorg Chem 36: 121-127. 
CAPÍTULO 3 
CAPÍTULO 4

CAPÍTULO 4 
CAPÍTULO 4 


\section{CAPÍTULO 4}

\section{Identification of surface proteins from Lactobacillus casei BL23 able to bind fibronectin and collagen}

Diego Muñoz-Provencio, Gaspar Pérez-Martínez and Vicente Monedero

Laboratorio de Bacterias Lácticas y Probióticos. Instituto de Agroquímica y Tecnología de Alimentos-CSIC. Av. Agustín Escardino 7, 46980 Paterna, Valencia, Spain

Published in Journal of Probiotics and Antimicrobial Proteins (2011) 3(1): 15-20 


\section{CAPÍTULO 4}

\section{ABSTRACT}

Strains of lactobacilli show the capacity to attach to extracellular matrix proteins. Cell-wall fractions of Lactobacillus casei BL23 enriched in fibronectin and collagen binding proteins were isolated. Mass spectrometry analysis of their protein content revealed the presence of stress-related proteins (GroEL, ClpL), translational elongation factors (EF-Tu, EF-G), oligopeptide solutebinding proteins and the glycolytic enzymes enolase and glyceraldehyde-3-phosphate dehydrogenase (GAPDH). The latter two enzymes were expressed in Escherichia coli and purified as glutathione-S-transferase (GST) fusion proteins and their in vitro binding activity to fibronectin and collagen was confirmed. These results reinforce the idea that lactobacilli display on their surfaces a variety of moonlighting proteins that can be important in their adaptation to survive at intestinal mucosal sites and in the interaction with host cells.

Keywords: Lactobacillus, surface proteins, fibronectin, collagen 


\section{INTRODUCTION}

Probiotic microorganisms have adapted to the specific environmental conditions of the digestive tract by developing mechanisms to persist and interact with the host mucosa. Among these mechanisms, attachment to epithelial surfaces is a widely distributed characteristic in lactobacilli and, although some controversy exists, it has been applied as a criterion for probiotic strain selection and, in some cases, it has been related to their health-promoting effects in the human gut (Velez, et al., 2007, Sanchez, et al., 2008).

In silico analyses of the exoproteome of probiotic intestinal lactobacilli identified a variety of secreted proteins which are putatively targeted to the cell surface and therefore contain motifs involved in peptidoglycan interaction (e.g. LysM, WxL, SH3) or possess specific covalent anchoring (lipoprotein or sortasedependent anchor) (Kleerebezem, et al., 2010).

However, biochemical and genetic characterization of proteic factors able to interact with mucosal surfaces (extracellular matrix (ECM) proteins, mucus and epithelial cells) revealed in most cases the occurrence of cytoplasmic housekeeping proteins. This correlates with the fact that a high proportion of extracellular and surfaceexposed proteins lack detectable secretion or retention signals (Beck, et al., 2009, Izquierdo, et al., 2009, Sanchez, et al., 2009).

The mechanism by which these proteins are exported and attached at the surface is intriguing and it is referred as non-classical protein secretion, for which a possible mechanism has been recently proposed (Pasztor, et al., 2010). In this sense, studies on the surface location of glyceraldehyde-3-phosphate dehydrogenase (GAPDH) in Lactobacillus plantarum 299v show that the presence of the enzyme at the cell-wall correlates to increased membrane permeability throughout the growth phase (Saad, et al., 2009) and it has been reported that surface association of enolase and GAPDH in Lactobacillus crispatus only occurs at acidic $\mathrm{pH}$ and it is dependent on its interaction with lipoteichoic acids (Antikainen, et al., 2007) 


\section{CAPÍTULO 4}

The association of cytoplasmic proteins to bacterial surfaces is also a common finding in pathogens and they have been linked to bacterial attachment to tissues and virulence (Pancholi \& Chhatwal, 2003). This suggests that, although lactobacilli lack the classical ECMbinding proteins found in some pathogens, common attachment mechanisms are shared between these bacteria. In addition to their role in mucosal attachment, some of the identified surface adhesins from lactobacilli have been suggested to interfere with pathogen binding or to participate in the maintenance of the gastrointestinal homeostasis by the modulation of immune processes (Bergonzelli, et al., 2006, Antikainen, et al., 2007, Spurbeck \& Arvidson, 2010).

In this work, with the aim of analyzing adhesion factors that could contribute to mucosal attachment, we have characterized surface proteins that interact with the ECM proteins fibronectin and collagen from Lactobacillus casei BL23, a strain with probiotic potential (Maze, et al., 2010). Our results show that a variety of housekeeping proteins and enzymes may exert adhesion-related functions in this bacterium. 


\section{MATERIALS AND METHODS}

\section{Bacterial strains and growth conditions}

Lactobacillus casei BL23 was grown in MRS medium (Difco) at $37^{\circ} \mathrm{C}$ under static conditions. Escherichia coli DH5 $\alpha$ was used as a host for gene cloning. E. coli BL21(DE3)[pLysS] and BL21(DE3)[pREP4GroES/EL](Dale, et al., 1994) were used for protein expression and purification. These strains were grown in LB medium at $37^{\circ} \mathrm{C}$ under agitation or in LB agar plates (1.8\% agar $\left.\mathrm{w} / \mathrm{v}\right)$. Antibiotics used were ampicillin at $100 \mu \mathrm{g} / \mathrm{ml}$, chloramphenicol at 20 $\mu \mathrm{g} / \mathrm{ml}$ and kanamycin at $25 \mu \mathrm{g} / \mathrm{ml}$.

\section{Isolation of $L$. casei surface proteins and immunoplate binding}

L. casei BL23 was grown in $40 \mathrm{ml}$ of MRS until an OD550nm of 0.9. The bacterial cells were recovered by centrifugation, washed two times with phosphate buffered saline (PBS) pH 7.4 and resuspended in $5 \mathrm{ml}$ of PBS containing $1 \mathrm{mM}$ EDTA and $1 \mathrm{mM}$ phenylmethyl sulphonyl fluoride.

Bacteria were broken with glass beads ( $0.1 \mathrm{~mm}$ diameter) in a Bead-beater apparatus (Biospec) for four cycles of $30 \mathrm{~s}$ at maximal speed. Unbroken cells were eliminated by centrifugation at 6,000 $\mathrm{g} g$ for $5 \mathrm{~min}$ at 4 으, the supernatant was recovered and the centrifugation step was repeated twice. The supernatant was then centrifuged at 22,000 $\times \mathrm{g} 20 \mathrm{~min}$ at $4 . \mathrm{O} \mathrm{C}$ and the pellet washed with $50 \mathrm{mM}$ Tris- $\mathrm{HCl} \mathrm{pH} 8$ containing $0.5 \mathrm{M} \mathrm{NaCl}$ three times under the same centrifugation conditions. The pellet containing the cellenvelope fraction (cell-walls plus membranes) was finally resuspended in $50 \mu$ l of $50 \mathrm{mM}$ Tris- $\mathrm{HCl} \mathrm{pH} 8$.

96-well Polysorp (Nunc) and Costar 3591 immunoplates were used for fibronectin and collagen, respectively, and were coated overnight at $4=\mathrm{C}$ with $50 \mu \mathrm{g} / \mathrm{ml}$ of each protein in $50 \mathrm{mM}$ carbonate/bicarbonate buffer $\mathrm{pH} 9.6$ (fibronectin, 2 wells per assay) or PBS pH 5.5 (collagen, 2 wells per assay). Wells were washed three times with PBS containing 0.1\% Tween-20 (PBST), blocked for $2 \mathrm{~h}$ at $37{ }^{\circ} \mathrm{C}$ with $\mathrm{PBS}$ plus $1 \% \mathrm{BSA}$ and washed again. 


\section{CAPÍTULO 4}

Cell-envelope proteins were added to wells in PBS plus $0.1 \%$ BSA (100 $\mu \mathrm{l} /$ well containing $20 \mu \mathrm{g}$ protein). After an overnight incubation at 4 으 $\mathrm{C}$ the wells were washed with PBST twenty times and bound proteins released by adding $30 \mu \mathrm{l} /$ well of $1 \mathrm{x}$ Laemmli loading buffer and mixing for $10 \mathrm{~min}$. Samples were loaded onto $10 \%$ SDSPAGE gels that were stained with silver nitrate.

Each experiment was repeated at least three times with extracts isolated from independent cultures. Protein bands were excised from the gels, trypsinized and identified by LC-ESI-MS/MS at the Proteomics Laboratory of the Centro de Investigación Principe Felipe, member of Proteored.

\section{Purification of GST fusion proteins}

The enolase (eno; LCABL_11330) and GAPDH (gap; LCABL_11300) encoding genes were amplified by PCR with oligonucleotides:

ENO_FOR (5'-GAAGGATCCATGTCTATCATTACTGAT)/

ENO_REV (5'-TTAAAGCTTTTAGTCGATTGCTTTCAC) and

GA3P_FOR (5'-GGAAATGGATCCATGACTGTTAAGATTGG)/

GAP3P_REV (5'-GTTACAAGCTTTTAGAGAGTAGCAAATTTCAGC), respectively (restriction sites were introduced for cloning and are underlined), using chromosomal DNA from L. casei BL23 as a template and Platinum Pfx DNA polymerase (Invitrogene).

The PCR products thus obtained were purified with the GFX PCR and gel band isolation kit (GE Healthcare) and digested with BamHI and HindIII for cloning into pGEX2t plasmid (GE Healthcare). The recombinant plasmids containing fusions of eno and gap genes to the gene encoding GST were verified by sequencing and transformed into E. coli BL21(DE3)[pLysS].

E. coli transformants carrying the pGEX2t derivatives were grown in $500 \mathrm{ml}$ of LB with antibiotics and induction of the genes was achieved by adding isopropyl- $\beta$-D-thiogalactopyranoside at $1 \mathrm{mM}$ when the cultures reached an OD550nm of 0.6 , followed by incubation for four hours. 
Under these conditions the GST-enolase recombinant protein was present as inclusion bodies and therefore the pGEX2t derivative carrying eno was transferred to E. coli BL21(DE3)[pREP4GroES/EL] strain, which expresses chaperones that facilitate protein folding. In this strain induction was carried out with $0.1 \mathrm{mM}$ isopropyl- $\beta-D-$ thiogalactopyranoside. Bacterial cells were washed with $100 \mathrm{mM}$ Tris- $\mathrm{HCl} \mathrm{pH} \mathrm{7.4,} \mathrm{resuspended} \mathrm{in} 10 \mathrm{ml}$ of $100 \mathrm{mM}$ Tris- $\mathrm{HCl} \mathrm{pH} \mathrm{7.4,} 0.5$ $\mathrm{mM}$ phenylmethyl sulphonyl fluoride, $0.5 \mathrm{mM}$ dithiothreitol $(1 \mathrm{mg} / \mathrm{ml}$ of lysozyme was added for the BL21(DE3)[pREP4GroES/EL] strain, followed by $30 \mathrm{~min}$ incubation at $37^{\circ} \mathrm{C}$ ). The suspension was sonicated and cellular debris was eliminated by centrifugation at $12,000 \times \mathrm{g} 10 \mathrm{~min}$ at $4{ }^{\circ} \mathrm{C}$. The supernatants were filtered through $0.45 \mu \mathrm{m}$ pore nitrocellulose filters, applied to $1 \mathrm{ml}$ Glutathione Sepharose $4 B$ columns and proteins were purified following the indications of the supplier (GE Healthcare).

\section{Immunoplate binding assays with purified proteins}

96-wells immunoplates (Costar 3591) were coated with BSA, fibronectin or collagen at $20 \mu \mathrm{g} / \mathrm{ml}$ overnight at 4 으 in $50 \mathrm{mM}$ carbonate/bicarbonate buffer $\mathrm{pH} 9.6$ (BSA and fibronectin) or PBS pH 5.5 (collagen). After three washes with PBS, the wells were blocked for $2 \mathrm{~h}$ with PBS containing $3 \% \mathrm{BSA}$ at $37^{\circ} \mathrm{C}$, washed again and $5 \mu \mathrm{g}$ of GST, GST-enolase or GST-GAPDH added in $100 \mu$ of PBS. Plates were incubated for $16 \mathrm{~h}$ at $4{ }^{\circ} \mathrm{C}$ and washed three times with PBST, after which $100 \mu \mathrm{l} /$ well of a 1:20,000 dilution of a rabbit anti-GST serum plus a 1:20,000 dilution of horseradish peroxidase-conjugated antirabbit IgG (GE Healthcare) in PBS plus 3\% BSA was added. After $1 \mathrm{~h}$ at room temperature, the wells were washed with PBST and developed with $100 \mu \mathrm{l} /$ well of $1-$ Step $^{\mathrm{TM}}$ Ultra TMB-ELISA substrate (Pierce). The

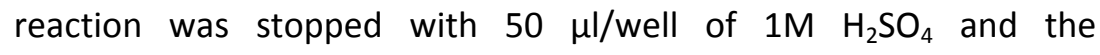
absorbance at $414 \mathrm{~nm}$ was measured in a Multiskan Ascent plate reader (Thermo-Labsystems). 


\section{CAPÍTULO 4}

\section{RESULTS}

\section{L. casei BL23 surface proteins that bind fibronectin and collagen}

The cell-envelope fractions of $L$. casei BL23 containing bound proteins were incubated with fibronectin or collagen immobilized on immunoplates and their protein content was analyzed by SDS-PAGE. $A$ variety of peptides were detected in both cases and similar banding patterns were obtained (Fig. 1).

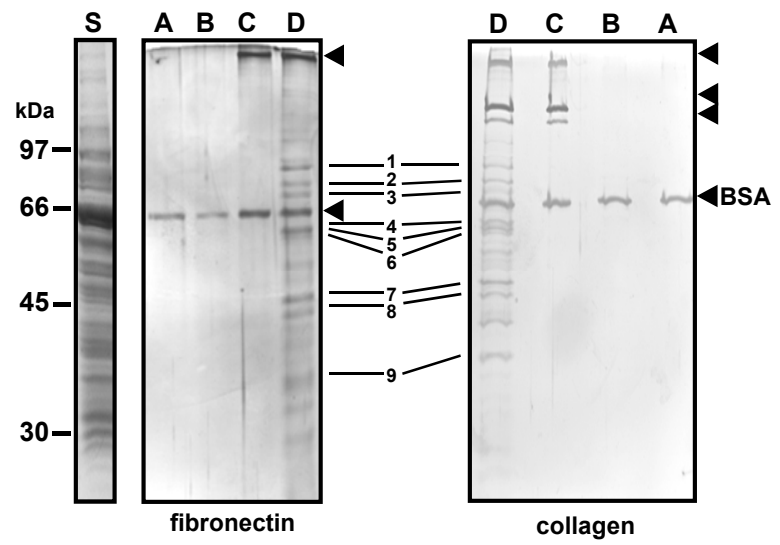

Figure 1. SDS-PAGE analysis of L. casei BL23 surface proteins able to interact with fibronectin and collagen. Proteins recovered from immunoplates were loaded onto SDS-PAGE gels and silver stained. Lanes A, wells blocked with $\mathrm{BSA}$; lanes B, wells blocked with BSA and incubated with L. casei BL23 proteins; lanes $C$, wells with immobilized fibronectin or collagen and blocked with BSA; lanes $D$, wells with immobilized fibronectin or collagen, blocked with BSA and incubated with L. casei BL23 proteins. Lane $S$ is a Coomassie straining of the whole BL23 surface protein fraction. The positions of BSA, fibronectin and collagen are indicated by black triangles. Numbers indicate the $L$. casei proteins that were analyzed by mass spectrometry.

Among the detected proteins, nine major bands were excised from the gels and subjected to mass spectrometry analysis. Table 1 shows the results of protein identification, which confirmed that identical $L$. casei proteins were isolated from cell-wall fractions interacting with fibronectin and collagen. 
CAPÍTULO 4

Table 1. Surface proteins from $L$. casei BL23 that interact with fibronectin and collagen

\begin{tabular}{lllccc}
\hline $\begin{array}{l}\text { band } \\
\text { no. }^{\text {a }}\end{array}$ & protein & accession no. & $\begin{array}{l}\text { mol. } \\
\text { weight } \\
\text { (kDa) }\end{array}$ & $\begin{array}{l}\text { MS } \\
\text { peptides }\end{array}$ & score $^{c}$ \\
\hline 1 & not identified & - & - & - & - \\
2 & $\begin{array}{l}\text { Elongation factor G } \\
\text { (EF-G) }\end{array}$ & gi|191639433 & 76.7 & 10 & 484 \\
3 & ClpL & gi|191638971 & 78.4 & 10 & 379 \\
4 & OppA1 & gi|191638594 & 66.4 & 22 & 967 \\
5 & OppA2 & gi|190713174 & 61.2 & 10 & 809 \\
6 & GroEL & gi|190713480 & 57.3 & 5 & 246 \\
7 & $\begin{array}{l}\text { Elongation factor Tu } \\
\text { (EF-Tu) }\end{array}$ & gi|190712633 & 43.4 & 9 & 440 \\
8 & Enolase & gi|190712212 & 46.9 & 9 & 451 \\
9 & GAPDH & gi|190712209 & 36.5 & 5 & 207 \\
\hline
\end{tabular}

aband numbers correspond to those represented in Figure 1 ; ${ }^{b}$ number of peptides matching the identified protein; ' scores obtained by using the MASCOT search engine

The identified proteins fell within four functional groups. The first group was composed by two proteins involved in stress response, ClpL and GroEL, the ATPase subunit of the Clp protease involved in degradation of missfolded proteins and a molecular chaperone, respectively. The second group comprised two factors (EF-Tu and EF-G) involved in peptide elongation during protein synthesis at the ribosome.

The third group was formed by two solute-binding proteins, OppA1 and OppA2, sharing a $23 \%$ amino acid identity. The genes coding for these proteins were clustered with genes encoding the corresponding subunits (integral membrane permeases $o p p B C$ and 


\section{CAPÍTULO 4}

ATPase subunits oppDF) of two distinct $A B C$ transporters putatively involved in oligopeptide uptake. The last group consisted of two enzymes, enolase and GAPDH, that catalyze reactions which are separated by two steps in glycolysis and are encoded in the same operon together with phosphoglycerate kinase (pgk; LCABL_11310) and triosephosphate isomerase (tpi; LCABL_11320).

With the exception of the two identified oligopeptide solutebinding proteins, which are extracellular lipoproteins carrying a peptidase II signal for covalent anchoring to the membrane, the rest of proteins were cytoplasmic proteins lacking recognizable secretion peptides.

\section{Verification of binding of enolase and GAPDH}

In order to confirm the results obtained above, we decided to overexpress and purify the two glycolytic enzymes that were detected in binding experiments. To this end, GST fusions were produced in E. coli and purified by affinity chromatography (Fig. 2).

Figure 2. SDS-PAGE analysis of purified GST fusion proteins to enolase and GAPDH from $L$. casei BL23. $\mathrm{Mw}$ is a molecular weight protein standard.

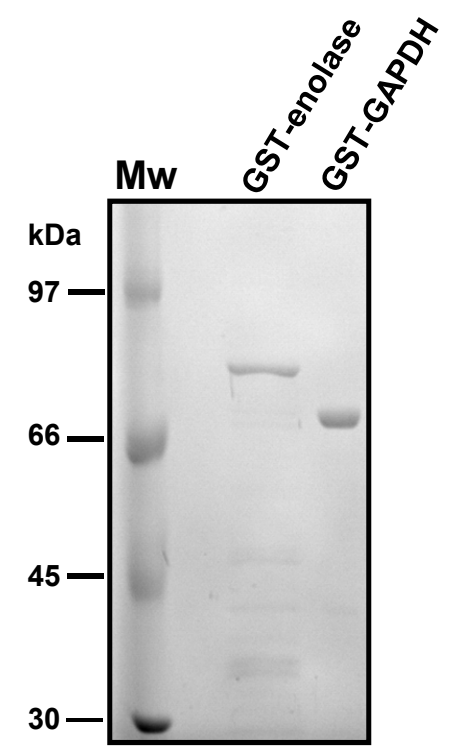


Figure 3 shows an ELISA experiment in which purified enolase and GAPDH were tested for binding to immobilized fibronectin and collagen. The two L. casei BL23 enzymes bound both substrates, while the GST control protein showed very low binding ability. All of them displayed a limited interaction with BSA. These results demonstrated that recombinant enolase and GAPDH retained their ability to interact specifically with ECM proteins.

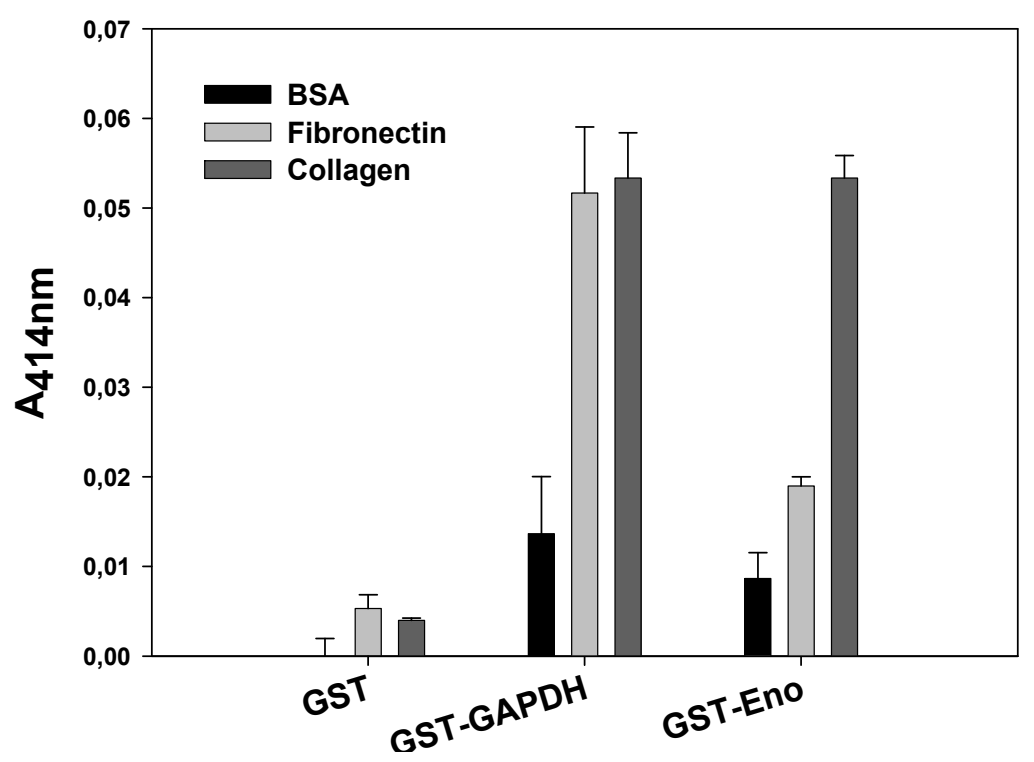

Figure 3. ELISA analysis of enolase and GAPDH binding to fibronectin and collagen. Immunoplates coated with BSA, fibronectin or collagen were incubated with different GST fusion proteins. After washing, bound proteins were detected with an anti-GST antibody. Values are means plus standard deviations from three experiments and were subtracted from absorbances obtained in blank wells. 


\section{CAPÍTULO 4}

\section{DISCUSSION}

Protein-dependent fibronectin and collagen binding has been reported in L. casei BL23 (Munoz-Provencio, et al., 2009, MunozProvencio, et al., 2010). In this work, several surface proteins of this microorganism were identified in cell wall fractions retained to these ECM proteins. With the exception of OppA1 and OppA2, they were anchorless proteins of cytoplasmic location implicated in the central metabolism, stress response and translation.

Interestingly all the proteins characterized here have been reported to contribute to bacterial adhesion. GAPDH and OppA1 orthologues have already been found in the cell surface of the phylogenetically-related Lactobacillus rhamnosus GG strain (Sanchez, et al., 2009). Moreover, related proteins were detected in high amounts in the cell-wall fractions of highly adhesive strains of other Lactobacillus species, which were shown to contribute to bacterial attachment (Izquierdo, et al., 2009). GroEL mediates epithelial cell attachment in lactobacilli and pathogens (Hennequin, et al., 2001, Bergonzelli, et al., 2006), and EF-Tu was identified as a molecule responsible for the attachment of Lactobacillus johnsonii NC533 to Caco-2 epithelial cells and mucin (Granato, et al., 2004). The solutebinding proteins from oligopeptide $A B C$ transporters are also widespread adhesins in probiotics. CnBP and MapA from Lactobacillus reuteri, which are homologues to OppA1 and OppA2 from $L$. casei BL23, were identified as mucus and collagen adhesion proteins that mediate attachment to epithelial cells (Roos, et al., 1996, Miyoshi, et al., 2006, Wang, et al., 2008). Similarly, the solutebinding protein BopA from Bifidobacterium bifidum MIMBb75 participates in binding to Caco-2 cells (Guglielmetti, et al., 2008) and a similar protein from Bifidobacterium longum VMKB44 adhered to the HT-29 cell line (Shkoporov, et al., 2008).

Finally, the presence of glycolytic enzymes at the cell surface is a frequent finding in bacteria. Thus, enolase and GAPDH are important molecules displayed at the surface of pathogens and contribute to adhesion and virulence (Pancholi \& Chhatwal, 2003). 
In lactobacilli, these enzymes have been found at the surface, bind ECM proteins and mucin (Kinoshita, et al., 2008, Castaldo, et al., 2009, Sanchez, et al., 2009, Spurbeck \& Arvidson, 2010) and, similar to pathogens, enhance activation of human plasminogen. However, the biological role of this interference in host pathways is not yet understood (Antikainen, et al., 2007).

In a previous work, two surface-located endolysins from $L$. casei BL23 (p40 and p75, (Bäuerl, et al., 2010)) were shown to interact with collagen, and another protein, $\mathrm{FbpA}$, was characterized which possessed fibronectin-binding capacity (Munoz-Provencio, et al., 2010). Nevertheless, these proteins were not identified in this work. Two possible reasons might explain this fact: first, a variety of proteins were detected by silver staining but only some of them were identified by mass spectrometry; second, p40 and p75 were loosely attached to $L$. casei cell surface and therefore they could have been lost during the washing steps employed for protein extracts purification.

This work describes the identification of a variety of $L$. casei surface proteins that had the potential to interact with ECM components, which suggests that protein-mediated adhesion may be a multifactorial process. As an example, and in parallel to our results, screening for surface proteins able to bind salivary mucin in the mucosal commensal Streptococcus gordonii led to the identification of EF-Tu, EF-G, enolase and oligopeptide solute-binding proteins (Kesimer, et al., 2009).

Here, the two glycolytic elements were further cloned and purified, showing that $L$. casei BL23 GAPDH and enolase unspecifically bound fibronectin and collagen. This fact had already been described in the literature. For example, the OppA orthologues in L. reuteri strains were able to bind collagen, mucus components and Caco-2 cells (Roos, et al., 1996, Miyoshi, et al., 2006, Wang, et al., 2008) and the $L$. crispatus ST1 enolase binds collagen, laminin and fibrinogen (Antikainen, et al., 2007). 


\section{CAPÍTULO 4}

ECM proteins and mucin are characterized by being highly modified, mainly by glycosylation. It is therefore likely that most of the identified proteins possess lectin-like capacity, which would explain their broad interaction spectrum. Surface lectin-like activity was early reported in lactobacilli (Mukai, et al., 1992) and specific binding to glycoconjugates present in human mucosa has been detected in these bacteria (Mukai, et al., 2004, Uchida, et al., 2006). Supporting this concept, surface proteins from Lactococcus lactis IL1403, including GroEL and GAPDH, bind to yeast mannan (Katakura, et al., 2010) and GAPDH from L. plantarum LA318 and a solutebinding protein from Lactobacillus mucosae ME-340 are able to recognize the oligosaccharides that define the human blood groups $A$ and B (Kinoshita, et al., 2008, Watanabe, et al., 2010).

In conclusion, diverse proteins were found at a surface location in L. casei BL23 that could interact with ECM proteins. These proteins were commonly isolated in other lactobacilli as putative adhesins and, for some of them; specific functions in the cross-talk between bacteria and host cells have been suggested. Therefore, they could play an important role in the persistence and physiology of these bacteria at mucosal niches.

\section{ACKNOWLEDGEMENTS}

This work was supported by projects AGL2004-00176/ALI and Consolider Fun-c-Food CSD2007-00063 from the Spanish Ministry of Science and Innovation. Diego Muñoz-Provencio was recipient of a research fellowship from the Instituto Danone. We thank Manuel Zúñiga for critical reading and suggestions. 


\section{REFERENCES}

Antikainen J, Kuparinen V, Lahteenmaki K \& Korhonen TK (2007) pHdependent association of enolase and glyceraldehyde-3phosphate dehydrogenase of Lactobacillus crispatus with the cell wall and lipoteichoic acids. J Bacteriol 189: 4539-4543.

Antikainen J, Kuparinen V, Lahteenmaki K \& Korhonen TK (2007) Enolases from Gram-positive bacterial pathogens and commensal lactobacilli share functional similarity in virulence-associated traits. FEMS Immunol Med Microbiol 51: 526-534.

Bäuerl C, Pérez-Martínez G, Yan F, Polk D.B. \& Monedero V (2010) Functional characterization of the p40 and p75 proteins from Lactobacillus casei BL23. J Mol Microbiol Biotechnol in press.

Beck HC, Madsen SM, Glenting J, et al. (2009) Proteomic analysis of cell surface-associated proteins from probiotic Lactobacillus plantarum. FEMS Microbiol Lett 297: 61-66.

Bergonzelli GE, Granato D, Pridmore RD, Marvin-Guy LF, Donnicola D \& Corthesy-Theulaz IE (2006) GroEL of Lactobacillus johnsonii La1 (NCC 533) is cell surface associated: potential role in interactions with the host and the gastric pathogen Helicobacter pylori. Infect Immun 74: 425-434.

Castaldo C, Vastano V, Siciliano RA, et al. (2009) Surface displaced alfaenolase of Lactobacillus plantarum is a fibronectin binding protein. Microb Cell Fact 8: 14

Dale GE, Schonfeld HJ, Langen H \& Stieger $M$ (1994) Increased solubility of trimethoprim-resistant type S1 DHFR from Staphylococcus aureus in Escherichia coli cells overproducing the chaperonins GroEL and GroES. Protein Eng 7: 925-931.

Granato D, Bergonzelli GE, Pridmore RD, Marvin L, Rouvet M \& CorthesyTheulaz IE (2004) Cell surfaceassociated elongation factor Tu mediates the attachment of Lactobacillus johnsonii NCC533 (La1) to human intestinal cells and mucins. Infect Immun $\mathbf{7 2}$ : 2160-2169.

Guglielmetti S, Tamagnini I, Mora D, et al. (2008) Implication of an outer surface lipoprotein in adhesion of Bifidobacterium bifidum to Caco-2 cells. Appl Environ Microbiol 74: 4695-4702.

Hennequin C, Porcheray $F$, WaligoraDupriet A, Collignon A, Barc $M$, Bourlioux $P$ \& Karjalainen $T$ (2001) GroEL (Hsp60) of Clostridium difficile is involved in cell adherence. Microbiology 147: 87-96.

Izquierdo E, Horvatovich $\mathrm{P}$, Marchioni E, Aoude-Werner D, Sanz $Y$ \& Ennahar S (2009) 2-DE and MS analysis of key proteins in the adhesion of Lactobacillus plantarum, a first step toward early selection of probiotics based on bacterial biomarkers. Electrophoresis 30: 949-956.

Katakura Y, Sano R, Hashimoto T, Ninomiya K \& Shioya S (2010) 


\section{CAPÍTULO 4}

Lactic acid bacteria display on the cell surface cytosolic proteins that recognize yeast mannan. Appl Microbiol Biotechnol 86: 319-326.

Kesimer M, Kilic N, Mehrotra R, Thornton DJ \& Sheehan JK (2009) Identification of salivary mucin MUC7 binding proteins from Streptococcus gordonii. BMC Microbiol 9: 163.

Kinoshita $\mathrm{H}$, Uchida $\mathrm{H}$, Kawai $\mathrm{Y}$, et al. (2008) Cell surface Lactobacillus plantarum LA 318 glyceraldehyde-3-phosphate dehydrogenase (GAPDH) adheres to human colonic mucin. J Appl Microbiol 104: 1667-1674.

Kleerebezem $M$, Hols $P$, Bernard E, Rolain $T$, Zhou M, Siezen RJ \& Bron PA (2010) The extracellular biology of the lactobacilli. FEMS Microbiol Rev 34: 199-230.

Maze A, Boel G, Zuniga M, et al. (2010) Complete genome sequence of the probiotic Lactobacillus casei strain BL23. J Bacteriol 192: 2647-2648.

Miyoshi Y, Okada S, Uchimura T \& Satoh E (2006) A mucus adhesion promoting protein, MapA, mediates the adhesion of Lactobacillus reuteri to Caco-2 human intestinal epithelial cells. Biosci Biotechnol Biochem 70: 1622-1628.

Mukai T, Arihara K \& Itoh H (1992) Lectinlike activity of Lactobacillus acidophilus strain JCM 1026. FEMS Microbiol Lett 98: 71-74.

Mukai T, Kaneko S, Matsumoto M \& Ohori H (2004) Binding of Bifidobacterium bifidum and Lactobacillus reuteri to the carbohydrate moieties of intestinal glycolipids recognized by peanut agglutinin. Int J Food Microbiol 90: 357-362.

Munoz-Provencio D, Perez-Martinez G \& Monedero V (2010)

Characterization of a fibronectinbinding protein from Lactobacillus casei BL23. J Appl Microbiol 108: 1050-1059.

Munoz-Provencio D, Llopis $M$, Antolin M, de Torres I, Guarner F, PerezMartinez G \& Monedero $V$ (2009) Adhesion properties of Lactobacillus casei strains to resected intestinal fragments and components of the extracellular matrix. Arch Microbiol 191: 153-161.

Pancholi V \& Chhatwal GS (2003) Housekeeping enzymes as virulence factors for pathogens. Int J Med Microbiol 293: 391401.

Pasztor L, Ziebandt AK, Nega M, et al. (2010) The staphylococcal major autolysin (ATL) is involved in excretion of cytoplasmic proteins. Journal of Biological Chemistry 285: 36794-36803.

Roos S, Aleljung P, Robert N, Lee B, Wadstrom $T$, Lindberg $M$ \& Jonsson H (1996) A collagen binding protein from Lactobacillus reuteri is part of an $\mathrm{ABC}$ transporter system? FEMS Microbiol Lett 144: 33-38.

Saad N, Urdaci M, Vignoles C, Chaignepain S, Tallon R, Schmitter JM \& Bressollier P (2009) Lactobacillus plantarum 299v surface-bound GAPDH: a new insight into enzyme cell walls location. J Microbiol Biotechnol 19: 16351643. 
Sanchez B, Bressollier P \& Urdaci MC (2008) Exported proteins in probiotic bacteria: adhesion to intestinal surfaces, host immunomodulation and molecular cross-talking with the host. FEMS Immunol Med Microbiol 54: 1-17.

Sanchez B, Schmitter JM \& Urdaci MC (2009) Identification of novel proteins secreted by Lactobacillus rhamnosus GG grown in de Mann-RogosaSharpe broth. Lett Appl Microbiol 48: $618-622$.

Sanchez B, Schmitter JM \& Urdaci MC (2009) Identification of novel proteins secreted by Lactobacillus plantarum that bind to mucin and fibronectin. J Mol Microbiol Biotechnol 17: 158-162.

Shkoporov AN, Khokhlova EV, Kafarskaia LI, Pavlov KA, Smeianov VV, Steele JL \& Efimov BA (2008) Search for protein adhesin gene in Bifidobacterium longum genome using surface phage display technology. Bull Exp Biol Med 146: 782-785.

Spurbeck RR \& Arvidson CG (2010) Lactobacillus jensenii surfaceassociated proteins inhibit Neisseria gonorrhoeae adherence to epithelial cells. Infect Immun 78: 3103-3111.

Uchida $\mathrm{H}$, Kinoshita $\mathrm{H}$, Kawai $\mathrm{Y}$, et al. (2006) Lactobacilli binding human A-antigen expressed in intestinal mucosa. Res Microbiol 157: 659-665.

Velez MP, De Keersmaecker SC \& Vanderleyden J (2007) Adherence factors of Lactobacillus in the human gastrointestinal tract. FEMS Microbiol Lett 276: 140-148.

Wang B, Wei H, Yuan J, Li Q, Li Y, Li N \& Li $J$ (2008) Identification of a surface protein from Lactobacillus reuteri JCM1081 that adheres to porcine gastric mucin and human enterocytelike HT-29 cells. Curr Microbiol 57: 33-38.

Watanabe $\mathrm{M}$, Kinoshita $\mathrm{H}$, Nitta $\mathrm{M}$, et al. (2010) Identification of a new adhesin-like protein from Lactobacillus mucosae ME-340 with specific affinity to the human blood group $A$ and $B$ antigens. J Appl Microbiol 109: 927-35 
CAPÍTULO 5

CAPÍTULO 5 
CAPÍTULO 5 


\section{CAPÍTULO 5}

\section{Four sortase genes are present in the genome of Lactobacillus casei BL23. Mutant construction and characterization.}

Diego Muñoz-Provencio ${ }^{a}$, M. Carmen Collado ${ }^{a}$, Phillipe Langella ${ }^{\mathrm{b}}$, Luis $\mathrm{G}$. Bermúdez-Humarán ${ }^{\mathrm{b}}$, Vicente Monedero ${ }^{\mathrm{a}}$

${ }^{a}$ Laboratorio de Bacterias Lácticas y Probióticos. Instituto de Agroquímica y Tecnología de Alimentos-CSIC. Av. Agustín Escardino 7, 46980 Paterna, Valencia, Spain

bunité d'Ecologie et de Physiologie du Système Digestif, INRA, Domaine de Vilvert, 78352 Jouy-en-Josas Cedex, France. 


\section{CAPÍTULO 5}

\section{ABSTRACT}

The Lactobacillus casei BL23 genome encodes four sortase genes, two class A (srtA1 and srtA2) and two class C sortases (srtC1 and srtC2) clustered with their potential pilin subunit substrates. Twenty three putative sortase substrates were identified that harbored a consensus cleavage motif which does not deviate significantly from the LPXTG canonical sequence. Southern blot and homology searches determined that while $\operatorname{sr} A 1$, srtC1 and srtC2 presence is a common feature in L. casei strains, srtA2 is only present in a few strains. Single disruption mutants of all sortase genes and a double mutant for the two class A sortases were obtained. RT-PCR analysis showed that srtA1, srtC1 and srtC2 are clearly expressed during growth under laboratory conditions and that srtA2 expression becomes apparent when srtA1 is disrupted. The srtA1 and srtA1/srtA2 mutants experimented a significant decrease in the surface hydrophobicity, related to a substantial change in the cell surface characteristics. The anchorage to the cell wall of a recombinant form of the staphylococcal nuclease was affected in the srtA1 mutant and even more in the srtA1/srtA2 double mutant. The enzymatic activities of $\beta$ $\mathrm{N}$-acetyl-glucosaminidase and the cell-wall proteinase, two sortase substrates, in whole cells were diminished in the srtA1 mutant and to a greater extent in the double srtA1/srtA2 mutant. The percentage of adhesion to Caco-2 and HT-29 epithelial cell lines was significantly reduced for the srtA1/srtA2 double mutant in both cases and also to a lesser extent for the srtA2 mutant in the Caco-2 cell line. When we studied the adhesion properties to different cell matrix molecules (collagen, fibronectin and fibrinogen), only in the latter case statistically significant decreases were found for the srtC1 and the double mutant srtA1/srtA2 strains. The body of evidence suggests that SrtA1 probably acts as the housekeeping sortase in L. casei BL23, being responsible for the anchoring of the great majority of sortase substrates to the cell wall, some of which may play a role in bacterial adhesion. SrtA2 would carry out a redundant and complementary function that became apparent when SrtA1 activity is absent. 
CAPÍTULO 5

Keywords: Sortase, LPxTG motif, surface proteins, Lactobacillus casei, probiotic, adhesion. 


\section{CAPÍTULO 5}

\section{INTRODUCTION}

The murein sacculus of the Gram-positive bacteria confers protection from environmental challenges and serves as a scaffold for the assembly of secondary cell wall polymers (protein, carbohydrates, and teichoic acids) (Schaffer \& Messner, 2005, Silhavy, et al., 2010). Those macromolecular structures play an important role in the interaction of the cell with its surroundings, being responsible of its unique lifestyle. Among the secondary cell wall polymers, the surface proteins are important for processes such as cell wall metabolism, degradation and uptake of nutrients, adhesion to diverse substrates and host surfaces, invasion and signaling (Scott \& Barnett, 2006).

In Gram-positive bacteria, many surface proteins are covalently anchored to the cell wall envelope by a membrane-bound thiol-transpeptidase named sortase. Twelve years ago the first sortase was identified in Staphylococcus aureus by Mazmanian and colleagues. It was named SrtA, for surface protein sorting A since it sorts the proteins out to their proper location (Mazmanian, et al., 1999). The sortase substrates have an N-terminal signal peptide that directs them through the Sec pathway. The loss of the protein to the extracellular environment is prevented by a stretch of hydrophobic aminoacids followed by positively charged residues at the C-terminal region. In the membrane the substrate is accessible to the sortase which recognizes the conserved carboxylic sorting motif LPXTG (Marraffini, et al., 2006), cleaves between the threonine and the glycine and catalizes the formation of an amide bond between the Cterminal carboxyl group of the threonine and an amino group of peptide cross-bridges within cell wall peptidoglycan (Ton-That, et al., 1999).

Almost all Gram-positive bacteria encode more than one paralogous sortase gene which made necessary a classification. They can be grouped based on their sequence homology and distinct functions into four classes (Dramsi, et al., 2005). 
The members of the class A are the so-called "housekeeping" sortases. There is usually a unique representative per genome, ubiquitously expressed and responsible for the anchoring of the majority of the LPXTG-proteins that can be placed elsewhere in the chromosome. In the other three classes the sortase genes are positioned in the same transcriptional unit as their putative substrates. That is the case of class B sortases that anchor proteins involved in heme-iron acquisition (Maresso \& Schneewind, 2006), class $C$ that has been shown to participate in the elaboration of pili on the bacterial surface (Hendrickx, et al., 2011) and class D involved in the spore formation of bacilli and streptomyces (Elliot, et al., 2003, Marraffini \& Schneewind, 2006).

Two main objectives drive the current investigation on sortases. The first one is to stay ahead of the Gram-positive bacteria drug resistance traits. The increase in antibiotic-resistant infections is associated with increases in mortality and healthcare costs (Bonomo \& Rossolini, 2008). Without the sortase substrates many pathogens cannot sustain an infection. Thus, it may be possible to design sortase inhibitors in a rational manner taking advantage of the thiol active site feature of sortase or the conserved structure of its peptide substrate. These inhibitors could even discriminate between specific members of the sortase family and serve as an effective therapeutic strategy that may not be associated with the same resistance phenomena (Maresso \& Schneewind, 2008).

The second objective is to exploit the sortase catalized reaction in the field of protein engineering (Tsukiji \& Nagamune, 2009). The reaction was coined sortagging (Popp, et al., 2007) and can be triggered by the addition of calcium. It only requires a recombinant SrtA enzyme as a molecular stapler, a substrate protein with the LPXTG cleavage motif and another molecule (peptidic or not)

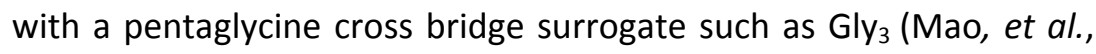
2004). The number of potential applications as arisen considerably and it ranges from one-step protein purification to incorporation of peptidic or non-peptidic moieties and even protein immobilization on solid surfaces (Parthasarathy, et al., 2007). 


\section{CAPÍTULO 5}

While the roles of sortase enzymes and its substrates are well documented in pathogens, only a few reports have examined these functions in other bacteria. Nowadays there is an increasing interest in marketing fermented foods that include probiotic bacteria among their ingredients and provide health benefits. In this scenario is of great interest to determine the role of sortases and their substrates in the interaction with the host, the adaptation to the intestinal environment and the probiotic traits performance.

A very limited number of studies have attempted to characterize these enzymes and their substrates in Lactobacillus, one of the most relevant probiotic genus within the lactic acid bacteria (LAB) (Pretzer, et al., 2005, van Pijkeren, et al., 2006, Gross, et al., 2008, Kankainen, et al., 2009, von Ossowski, et al., 2010). Lactobacillus casei is a natural inhabitant of the gastrointestinal tract. L. casei BL23, the object of this study, has been widely used for genetic, physiological and biochemical studies. It is easily transformable and its genome has recently been fully sequenced (Maze, et al., 2010). This strain exhibits probiotic properties in animal models. Its consumption confers a prophylactic protective capacity in a TNBS-induced colitis murine model, leading to a considerable attenuation in colitis (Foligne, et al., 2007).

In the present study, we searched the genome of $L$. casei BL23 for the presence of sortase gene homologues and sortasedependent-protein encoding genes. Functional characterization of targeted gene knockout mutants was employed to examine the role in adhesion of the sortase proteins. The in vitro adhesion data for epithelial cells demonstrate the role of sortase-dependent proteins in epithelial cell adhesion by L. casei BL23. 


\section{MATERIALS AND METHODS}

\section{Strains and growth conditions}

Lactobacillus casei strains are listed in Table 1 and were grown in MRS broth (BD Difco, Le Pont de Claix, France) at 37으 under static conditions. Escherichia coli $\mathrm{DH} 5 \alpha$ was used as a cloning host and was grown in LB medium at 37으 $\mathrm{C}$ under agitation (200 rpm). Antibiotics used were ampicillin at $100 \mu \mathrm{g} / \mathrm{ml}$ for E. coli and erythromycin and chloramphenicol at $5 \mu \mathrm{g} / \mathrm{ml}$ when used separately and at $2.5 \mu \mathrm{g} / \mathrm{ml}$ each when used together for L. casei. Solid medium was prepared by adding $1.8 \%$ agar. Bacterial growth curves were determined in microtiter plates ( $200 \mu \mathrm{l}$ MRS broth per well) at $37^{\circ} \mathrm{C}$ in a Polarstar Omega plate reader (BMG Labtech, Offenburg, Germany).

\section{Homology searches}

A bioinformatic approach was employed to identify genes encoding sortase enzymes and their putative substrates. Translations of the ORFs in the genome of L. casei BL23 were screened with pfsearch (pftools package, Swiss Institute for Experimental Cancer Research ISREC) (Bucher, et al., 1996) using the hidden Markov models from the Pfam database pf04203 (sortase) and pf00746 (Gram-positive anchor), respectively. 


\section{CAPÍTULO 5}

Table 1. Strains and plasmids used in this study

\begin{tabular}{|c|c|c|}
\hline Strain & Relevant characteristics & Reference/origin \\
\hline BL23 & wild type, genome sequenced & $\mathrm{CECT}^{\mathrm{a}} 5275$ \\
\hline BL32 & cheese isolate & CECT4040 \\
\hline BL82 & sour milk isolate & ATCC $^{b} 25598$ \\
\hline BL83 & cheese isolate & CECT4043 \\
\hline BL87 & oral cavity isolate & ATCC11578 \\
\hline BL90 & cheese isolate, genome sequenced & ATC 334 \\
\hline BL91 & dental caries isolate & ATCC4545 \\
\hline BL101 & isolated from commercial probiotic drink & laboratory stock \\
\hline BL106 & isolated from commercial probiotic drink & laboratory stock \\
\hline BL193 & isolated from commercial probiotic drink & laboratory stock \\
\hline BL199 & exopolysaccharide producer & $C R L^{\mathrm{C}} 87$ \\
\hline BL208 & human intestinal isolate & laboratory stock \\
\hline BL212 & dry cured sausage isolate & CRL686 \\
\hline BL227 & commercial probiotic & laboratory stock \\
\hline BL229 & commercial probiotic & laboratory stock \\
\hline BL341 & BL23 srtA1::pRV300 Ery ${ }^{r}$ & this work \\
\hline BL342 & BL23 srtA2::pRV300 Ery ${ }^{r}$ & this work \\
\hline BL343 & BL23 srtC1::pRV300 Ery ${ }^{r}$ & this work \\
\hline BL344 & BL23 srtC2::pRV300 Ery ${ }^{r}$ & this work \\
\hline BL347 & BL23 srtA1::pUCm1 $\mathrm{Cm}^{\mathrm{r}}$ & this work \\
\hline BL348 & BL23 srtA2::pUCm1 $\mathrm{Cm}^{\mathrm{r}}$ & this work \\
\hline BL346 & $\mathrm{BL} 23 \Delta s r t A 2$ & this work \\
\hline BL345 & $\mathrm{BL} 23 \Delta s r t A 2$ srtA1::pUCm1 $\mathrm{Cm}^{\mathrm{r}}$ & this work \\
\hline Plasmid & Description & Source/Reference \\
\hline pRV300 & $\begin{array}{l}\text { Sspl-restricted pBluescript SK- joined to a 1,130-bp Smal } \\
\text { fragment of pVE6023; Amp }{ }^{r} \text { Ery }^{r}\end{array}$ & $\begin{array}{l}\text { (Leloup, et al., } \\
\text { 1997) }\end{array}$ \\
\hline pUCm1 & $\begin{array}{l}\text { pUC19 derivative carrying the chloramphenicol marker of } \\
\text { pC194 at the Smal site; } \mathrm{Amp}^{r} \mathrm{Cm}^{r}\end{array}$ & $\begin{array}{l}\text { (Monedero, et } \\
\text { al., 1997) }\end{array}$ \\
\hline pNUC- & ColE1 pAM $\beta 1 ;$ & (Dieye, et al., \\
\hline CWA & $\begin{array}{l}\text { pBS::pIL252::ttrpA::P59::spUsp45::nucA::cwaM6D105::t1t2; } \\
\text { Amp }^{r} \text { Ery }^{r}\end{array}$ & 2001) \\
\hline
\end{tabular}




\section{Construction of $L$. casei mutants in srt genes}

Internal DNA fragments ranging from 350 to $390 \mathrm{bp}$ were amplified by PCR from the sortase genes srtA1, srtA2, srtC1 and srtC2 (LCABL_23200, LCABL_06160, LCABL_25390 and LCABL_05230, respectively) using primers listed in Table 2 obtaining blunt-ended DNA fragments. The PCR reaction was carried out using L. casei BL23 genomic DNA as a template and Platinum Pfx DNA polymerase (Invitrogen).

The fragments were cloned into the integrative vector pRV300 (Leloup, et al., 1997) treated with Smal allowing blunt-end cloning. The resulting plasmids, pRVsrtA1, pRVsrtA2, pRVsrtC1 and pRVsrtC2 were transformed by electroporation into BL23 strain by using a Gene-Pulser (Biorad) as previously described (Posno, et al., 1991) and transformants were selected in solid media by erythromycin resistance.

Integration at the correct loci and disruption was checked by Southern blot on Hindlll-digested genomic DNA for srtA1 and srtC2, Accl-digested for srtA2 and Kpnl-digested for srtC1 (Figure 5A). The probes were the plasmid inserts labelled with digoxigenin (DIG) with the PCR DIG-labeling mix (Roche). Hybridization and detection was performed in Hybond-N membranes (GE Healthcare) by using alkaline phosphatase-conjugated anti-DIG and the CDP-star chemiluminiscent reagent as recommended by the manufacturer (Roche).

The insertional mutation was shown to be stable for at least $\sim 40$ generations in the absence of antibiotic (screening of 600 colonies after two consecutive overnight cultures gave a $100 \%$ of erythromycin resistants). Therefore, to discard interferences resulting from growth with antibiotics, bacteria used for the binding experiments and for growth curves were grown in the absence of erythromycin.

The srtA2 gene was deleted by a double-crossover strategy. The $5^{\prime}$ - and $3^{\prime}$-end-flanking regions of the srtA2 gene (LCABL_06160) were amplified using the primer pairs A2_PRE_FOR, A2_PRE_REV and A2_POST_FOR, A2_POST_REV. 


\section{CAPÍTULO 5}

The amplicons were joined by splicing by overlap extension (SOE)-PCR using the primer pair A2_PRE_FOR, A2_POST_REV. The resultant $1.9-\mathrm{Kb}$ amplicon was digested using Sacl and HindIII and cloned into pRV300 digested with the same enzymes. The integrity of the transformants was verified by PCR, using primers PRE and POST located on pRV300.

Plasmid integrants in L. casei BL23 were constructed as described previously. Colonies resistant to erythromycin were tested to confirm upstream or downstream integration to srtA2 by $P C R$, using primer pairs SRTA2_REV, pRV300_REV and SRTA2_FOR, pRV300_FOR, respectively. Plasmid integrants were simple recombination occurred upstream or downstream were selected and cultured at $37{ }^{\circ} \mathrm{C}$ without antibiotic selection for at least 200 generations. Colonies were grown on MRS plates and screened for Ery $^{\mathrm{s}}$ phenotype by replica plating on MRS plates with $5 \mu \mathrm{g} / \mathrm{ml}$ of erythromycin. The occurrence of a double crossover event in Ery strains was confirmed by PCR using the primer pair A2_PRE_FOR, A2_POST_REV. (Figure 5B). The absence of srtA2 (LCABL_06160) was also verified by a negative amplification using the primer pair SRTA2_FOR and SRTA2_REV (data not shown).

For the Western blot experiment to study the anchoring to the cell wall of a fusion protein consisting in the staphylococcal nuclease fused to a cell wall sorting signal, sortase mutants with a chloramphenicol marker were constructed. Blunt-ended amplicons of the internal fragments of the genes srtA1 and srtA2 were obtained and cloned in pUCm1 (Monedero, et al., 1997) digested with Hincll.

The plasmids pUCsrtA1 and pUCsrtA2 were used to obtain disruption mutans srtA1::pUCm1; srtA2::pUCm1 and $\triangle$ srtA2, srtA1::pUCm1 double mutant. Integration at the correct loci and disruption was checked by Southern blot on HindIII-digested genomic DNA for srtA1 and Accl-digested for srtA2 (Figure 5A). 
CAPÍTULO 5

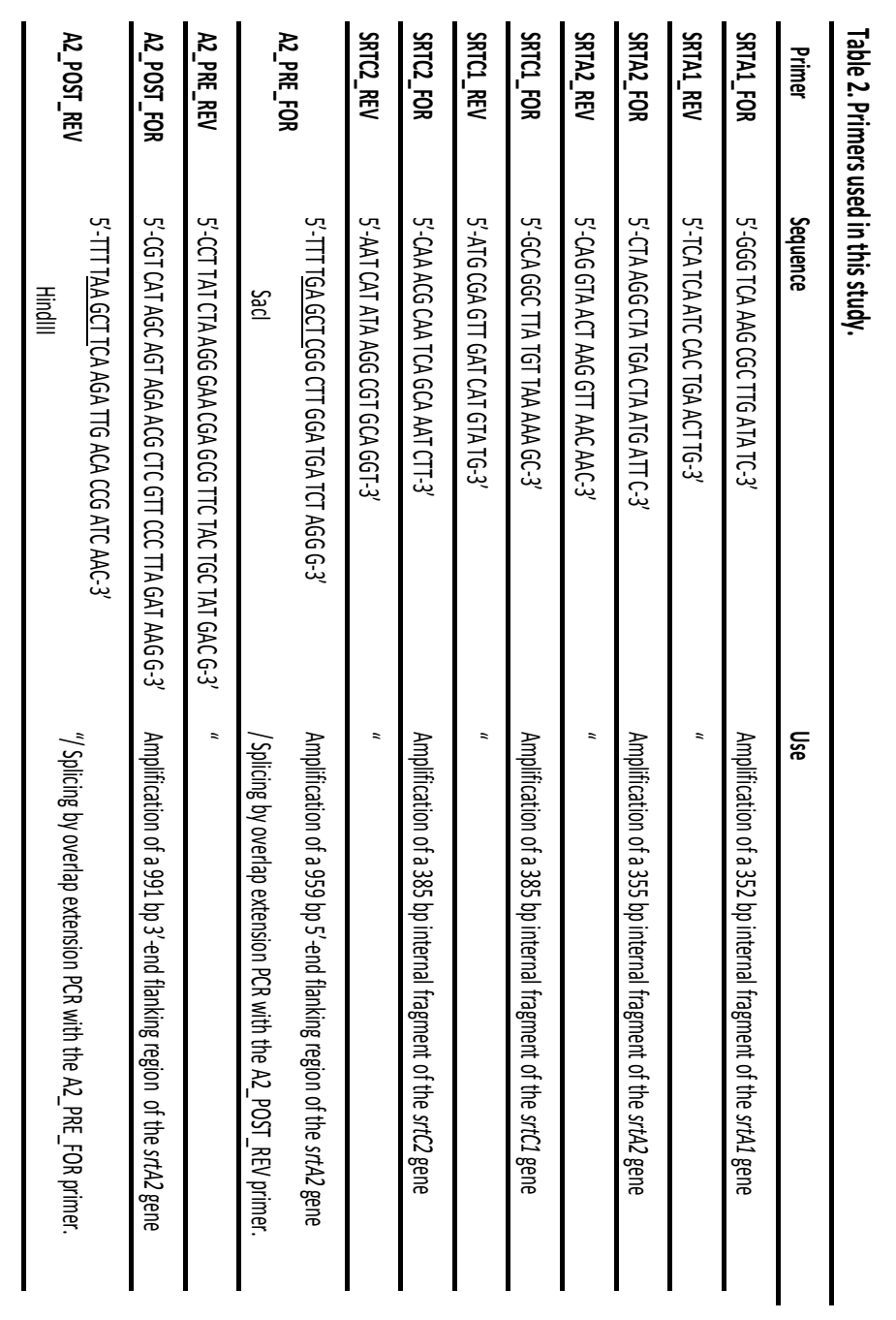




\section{CAPÍTULO 5}

\section{Adhesion to solvents test}

Microbial adhesion to solvent (MATS) test was performed essentially as described (Bellon-Fontaine, 1996). Five $\mathrm{ml}$ of overnight cultures of each strain were washed with phosphate-buffered saline (PBS; $\mathrm{pH}$ 7.2) and resuspended in PBS to a final $\mathrm{OD}_{600 \mathrm{~nm}}$ of $0.4\left(\mathrm{~A}_{0}\right)$. Three $\mathrm{ml}$ of this suspension were mixed with $1 \mathrm{ml}$ of different solvents (chloroform, ethyl-acetate or hexadecane) and the mixture was vortexed for $1 \mathrm{~min}$ at full speed. The mixture was let to stand for 20 min to allow phase separation and the absorbance of the aqueous phase was measured at $600 \mathrm{~nm}\left(A_{1}\right)$. The percentage of adhesion was calculated from: \%Adhesion $=100 \times\left[1-\left(A_{1} / A_{0}\right)\right]$. Each experiment was done in triplicate with cells coming from independent cultures.

\section{Adhesion to Caco-2 and HT-29 cell lines}

Epithelial cells were seeded at $4 \times 10^{4}$ cells $/ \mathrm{cm}^{2}$ (Caco-2) or $2 \times 10^{5}$ cells $/ \mathrm{cm}^{2}$ (HT-29) in 24-well plates in DMEM medium (with Glutamax, $25 \mathrm{mM}$ glucose; Gibco) supplemented with $1 \%(\mathrm{v} / \mathrm{v})$ nonessential amino acids solution (Gibco), $1 \%(\mathrm{v} / \mathrm{v})$ sodium pyruvate solution (Gibco), $1 \%(\mathrm{v} / \mathrm{v}$ ) sodium bicarbonate solution (Gibco, only for HT-29 cells), 1\% (v/v) of antibiotics (100 U per ml penicillin, 100 $\mu \mathrm{g} / \mathrm{ml}$ streptomycin, Gibco) and $10 \%(\mathrm{v} / \mathrm{v})$ fetal calf serum and incubated at $37^{\circ} \mathrm{C}$ in a $\mathrm{CO}_{2}$ incubator.

After the cells reached confluence (incubation for 6 and 3 days for Caco-2 and HT-29, respectively), plates were incubated for additional 15 (Caco-2) or 21 (HT-29) days to allow cell differentiation and the medium was changed every two days. L. casei cells were grown overnight, washed two times with PBS and stained with $75 \mu \mathrm{M}$ carboxyfluorescein diacetate (CFDA) in the absence of light for 30 minutes. After that, they were washed two times with PBS and stained bacterial cells were added to each well in $0.5 \mathrm{ml}$ of PBS adjusted to an $\mathrm{OD}_{550 \mathrm{~nm}}$ of $0.2\left(10^{8} \mathrm{cfu} / \mathrm{ml}\right)$. The plates were incubated for $1 \mathrm{~h}$ at $37^{\circ} \mathrm{C}$ in the absence of light. Aliquots of the stained cells were maintained in tubes under the same conditions and treated the same way from then on. 
Non-adhered bacteria were removed by washing 3 times with $1 \mathrm{ml}$ of PBS and the bacteria were detached by covering the monolayer with $200 \mu \mathrm{l}$ of a $15 \%(\mathrm{v} / \mathrm{v}$ ) solution of trypsin-EDTA (Gibco) in PBS, followed by the addition of $300 \mu$ of culture medium to stop trypsin reaction.

The fluorescence of the input and output fractions was measured in a Fluoroskan Ascent plate reader (Thermo Scientific) set at $485 \mathrm{~nm}$ excitation wavelength and $538 \mathrm{~nm}$ emission wavelength. The experiments were made in triplicate three times with bacteria coming from independent cultures. Adhesion was expressed as percentage of fluorescence recovered with respect to that of the input.

\section{Microtitre plate binding assays}

L. casei BL23 wild type and the sortase mutants were assayed for binding to different substrates immobilized on 96-well immunoplates. Polysorp Plates (Nunc) were covered with the different substrates overnight at $4 \stackrel{\circ}{ } \mathrm{C}$. Fibrinogen (fraction I from pig plasma, Sigma), fibronectin (human plasma, Sigma) and collagen (type I, Roche) were used at $25 \mu \mathrm{g} / \mathrm{ml}$ in $50 \mathrm{mM}$ carbonate/bicarbonate buffer $\mathrm{pH} 9.6$ (fibrinogen and fibronectin) or PBS pH 5.5 (collagen).

After immobilization, wells were washed two times with PBS and blocked for 2 hours at $37{ }^{\circ} \mathrm{C}$ with PBS plus 2\% BSA. After washing two times with PBS, one hundred $\mu$ of each strain labelled with 75 $\mu \mathrm{M}$ CFDA were added to each well in PBS adjusted to an $\mathrm{OD}_{550 \mathrm{~nm}}$ of 0.2 and plates were incubated overnight at $4 \stackrel{\circ}{ } \mathrm{C}$ in the absence of light. Aliquots of the input were maintained in tubes under the same conditions and processed the same way.

Non-adhered cells were removed by washing three times with $200 \mu \mathrm{l}$ of PBS plus $0.05 \%$ Tween 20 . To remove the adhered cells, $200 \mu \mathrm{l}$ of $1 \%$ SDS, $0.1 \% \mathrm{NaOH}$ was added per well and left for 1 hour at $37^{\circ} \mathrm{C}$. After homogenizing the solution by repetitive pipetting, it was transferred to a black 96 well plate. 


\section{CAPÍTULO 5}

Adhesion was expressed as percentage of fluorescence recovered with respect to that of the input. Experiments were carried out in triplicate three times with cells coming from independent cultures.

\section{Determination of enzymatic activities}

The $\mathrm{N}$-acetylglucosaminidase assay was carried out in a 250 $\mu$ volume containing $10 \mathrm{mM}$ potassium phosphate $(\mathrm{pH} 6.8), 1 \mathrm{mM}$ $\mathrm{MgCl}_{2}, 5 \mathrm{mM} p$-nitrophenyl- $N$-acetyl- $\beta$-D-glucosaminide (Sigma), and cells $\left(\mathrm{OD}_{550 \mathrm{~nm}}\right.$ of 6$)$ at $37^{\circ} \mathrm{C}$. The reaction was stopped with $250 \mu \mathrm{l}$ of $5 \% \mathrm{Na}_{2} \mathrm{CO}_{3}$, and the $\mathrm{OD}_{420 \mathrm{~nm}}$ was measured.

The cell envelope proteinase (PrtP) activity was determined on $\beta$-casein. L. casei BL23 and the sortase mutants were grown overnight in MRS plaques, collected with PBS from the surface and washed in the same buffer. The cells were adjusted to an $\mathrm{OD}_{550 \mathrm{~nm}}$ of 3 in $100 \mathrm{mM}$ MES buffer $\mathrm{pH} 7$ supplemented with $5 \mathrm{mM} \mathrm{CaCl} 2$. The cell suspension was mixed with the substrate $\beta$-casein $(4 \mathrm{mg} / \mathrm{ml}$ ) (Sigma) dissolved in the same buffer at a 3:1 volume ratio. After incubation $\mathrm{O} / \mathrm{N}$ at $37^{\circ} \mathrm{C}$, the cells were pelleted by centrifugation and $10 \mu \mathrm{l}$ aliquots were analyzed by SDS-PAGE.

\section{Isolation of cellular fractions and localization of Nuc reporter fusions}

L. casei strains transformed with pNUC-CWA were grown in $10 \mathrm{ml}$ of MRS to mid exponential phase $\left(\mathrm{OD}_{550 \mathrm{~nm}}\right.$ of $0.8-0.9 ; 5.8 \times 10^{8}$ to $6.6 \times 10^{8} \mathrm{cfu} / \mathrm{ml}$ ) and the conditioned media was retained as the secreted fraction. The cells were washed two times with PBS. The pellet was resuspended in $50 \mathrm{mM}$ Tris- $\mathrm{HCl}$ pH8.

The cell pellet was disrupted with glass beads $(0.1 \mathrm{~mm})$ in a Mini-Bead Beater (BioSpec Products, Bartlesville, OK, USA ) with four cycles of $30 \mathrm{~s}$ at maximal speed and unbroken cells were discarded by centrifuging the supernatant three times at $6000 \times \mathrm{xg}$ for $5 \mathrm{~min}$. The supernatant was then centrifuged at $22.000 \mathrm{xg}, 20 \mathrm{~min}$ at $4{ }^{\circ} \mathrm{C}$. 


\section{CAPÍTULO 5}

The pellet was washed three times at 22.000xg for $15 \mathrm{~min}$ with $50 \mathrm{mM}$ Tris- $\mathrm{HCl} \mathrm{pH} 8$ plus $0.5 \mathrm{M} \mathrm{NaCl}$ and retained as the cellenvelope fraction (cell-wall/membrane fragments). pNUC-CWA carries a cassette consisting in the strong constitutive lactococcal promoter $\mathrm{P}_{59}$, the signal peptide of the lactococcal Usp45 protein and the staphylococcal nuclease $A$ gene (nucA) fused to the sequence encoding the cell-wall anchor motif of the Streptococcus pyogenes M6 protein, followed by two transcriptional terminators.

Samples of the different fractions were separated on $15 \%$ SDS-PAGE gels $(0.5 \mu \mathrm{g}$ of cell-envelope fraction, $0.5 \mu \mathrm{l}$ of supernatant/conditioned media) and the proteins were electrotransferred to Hybond-ECL membranes (GE Healthcare). NucA was detected with a rabbit anti-NucA serum (1:5000) and the ECLadvance western blotting detection kit (GE Healthcare).

\section{RT-PCR analysis}

Total RNA was isolated from $10 \mathrm{ml}$ of exponentially growing L. casei BL23, BL341 and BL342 cells $\left(\mathrm{OD}_{550 \mathrm{~nm}}\right.$ of 0.9$)$ using the Trizol reagent as recommended by the supplier (Invitrogen). The RNA was treated with RNAase-free DNase I (Turbo DNA-free kit, Ambion) and $2 \mu \mathrm{g}$ were used to synthesize cDNA with the Superscript VILO cDNA synthesis kit as recommended by the manufacturer (Invitrogen).

RNA (60 ng), cDNA (5 ng) and chromosomal DNA samples (100 ng) were used to amplify fragments from srtA1, srtA2, srtC1 and srtC2 with the oligonucleotide pairs SRTA1_FOR/SRTA1_REV, SRTA2_FOR/SRTA2_REV, SRTC1_FOR/SRTC1_REV and SRTC2_FOR/SRTC2_REV, respectively, and the reaction products were separated in $1.5 \%$ agarose gels stained with ethidium bromide.

\section{Statistical analysis}

Student's $\mathrm{t}$ test was employed to investigate statistical differences with the PRISM 4.0 software (Graph Pad Software, San Diego, CA, USA). Samples with P values of $<0.05$ were considered statistically different. 


\section{CAPÍTULO 5}

\section{RESULTS}

The L. casei BL23 genome carries four sortase genes.

We identified four sortase genes in the L. casei BL23 genome using the HMM pf04203 and the bioinformatic tool pfsearch (ISREC Foundation). Two sortases belong to the class A (LCABL_23200 and LCABL_06160, named hereinafter srtA1 and srtA2, respectively) and two to the class C (LCABL_25390 and LCABL_05230, named srtC1 and srtC2, respectively) of sortases.

Table 3. Orthologues to the $L$. casei BL23 sortase proteins in other sequenced strains of the L. casei/rhamnosus group.

\begin{tabular}{|c|c|c|c|c|c|}
\hline & Organism & Protein & $\begin{array}{l}\text { Identity } \\
\%\end{array}$ & $\begin{array}{l}\text { Similarity } \\
\%\end{array}$ & $\begin{array}{l}\text { E } \\
\text { value }\end{array}$ \\
\hline & $\begin{array}{l}\text { Lactobacillus paracasei } \\
\text { subsp. paracasei ATCC } \\
25302\end{array}$ & ZP_03963898.1 & $100 \%$ & $100 \%$ & $\begin{array}{l}1 \mathrm{e}- \\
131\end{array}$ \\
\hline & $\begin{array}{l}\text { Lactobacillus casei ATCC } \\
334\end{array}$ & YP_807331.1 & “ & “ & " \\
\hline & $\begin{array}{l}\text { Lactobacillus paracasei } \\
\text { subsp. paracasei } 8700: 2\end{array}$ & ZP_04673028.1 & “ & “ & " \\
\hline \multirow{5}{*}{ SrtA1 } & $\begin{array}{l}\text { Lactobacillus casei } \\
\text { Zhang }\end{array}$ & YP_003789159.1 & “ & “ & “ \\
\hline & $\begin{array}{l}\text { Lactobacillus } \\
\text { rhamnosus LMS2-1 }\end{array}$ & ZP_04441772.1 & $84 \%$ & $94 \%$ & $\begin{array}{l}7 e- \\
113\end{array}$ \\
\hline & $\begin{array}{l}\text { Lactobacillus } \\
\text { rhamnosus HN001 }\end{array}$ & ZP_03210870.1 & “ & “ & " \\
\hline & $\begin{array}{l}\text { Lactobacillus } \\
\text { rhamnosus GG }\end{array}$ & YP_003171889.1 & “ & “ & " \\
\hline & $\begin{array}{l}\text { Lactobacillus } \\
\text { rhamnosus Lc } 705\end{array}$ & YP_003174840.1 & “ & “ & " \\
\hline SrtA2 & $\begin{array}{l}\text { Lactobacillus } \\
\text { rhamnosus Lc } 705\end{array}$ & $\begin{array}{l}\text { YP_003175623.1 } \\
\text { locus_tag= } \\
\text { "pLC705_00020" } \\
\text { plasmid="pLC1" }\end{array}$ & $97 \%$ & $100 \%$ & $\begin{array}{l}6 e- \\
122\end{array}$ \\
\hline
\end{tabular}


CAPÍTULO 5

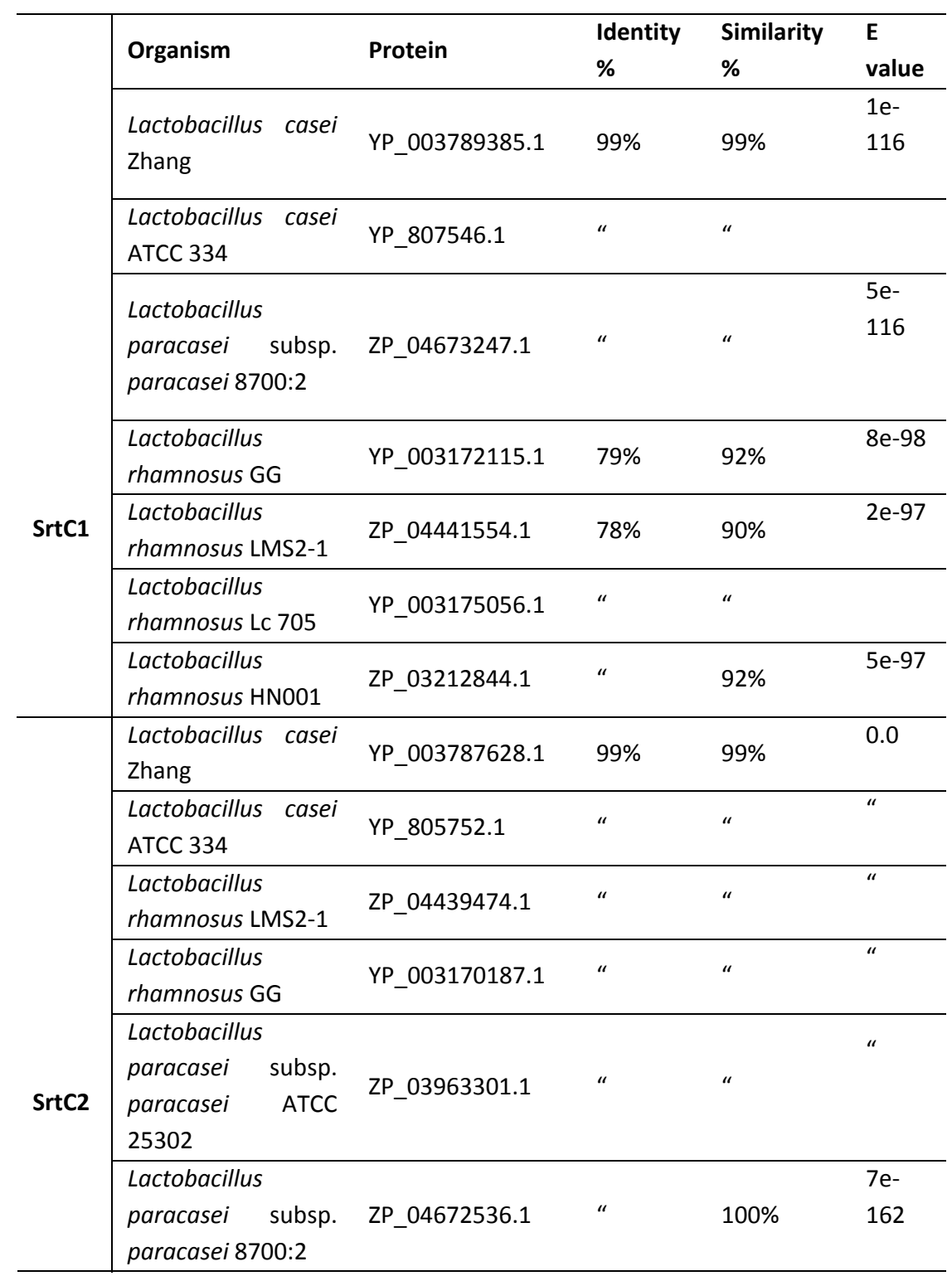

Orthologue proteins were identified in the Lactobacillus genus employing the Blastx program on fully sequenced genomes or ongoing sequencing projects. 


\section{CAPÍTULO 5}

Only results with identities above $75 \%$ and $E$ values below 1e-96 were considered and are presented in Table 3.

The analysis of the $L$. casei BL23 sortase protein sequences with the DAS transmembrane prediction server (Figure 1) revealed the presence of an $\mathrm{N}$-terminal signal peptide/transmembrane region in every case and an additional C-terminal hydrophobic domain in the two class $C$ sortases that could serve as a membrane anchor of type II and represents a characteristic for this type of sortases. The catalytic C-terminal signature of sortases (TLXTC) is represented by the sequences TMVTC for SrtA1, TLVTC for SrtA2 and TLMTC in both SrtC enzymes that also share a conserved proline residue after their catalytic signature.

The use of Blastn revealed the presence of orthologue genes of $\operatorname{srtA1}$ srtC1 and srtC2 in the sequenced genomes of more than six strains belonging to the $L$. casei-paracasei/rhamnosus group with identities over $78 \%$ at the protein level. On the other hand, srtA2 was only detected in L. casei ATCC334 as a pseudogen and in $L$. rhamnosus LC705 an SrtA2 homologue was plasmid-encoded (Table $3)$.

Southern blot analysis of a collection of $L$. casei strains from different origins (food and human isolates, including probiotic strains, Table 1) with srtA1, srtA2, srtC1 and srtC2 probes (Figure 2) confirmed the genome analysis, showing that copies of srtA1, srtC1 and srtC2 were present in all strains except BL199, BL212 and BL229. These strains are probably members of the $L$. rhamnosus species, where the lower sortase homology at the DNA level (around 70-76\%) could result in the absence of hybridization signal under stringent hybridization conditions. These results concluded that the presence of srtA1, srtC1 and srtC2 is a common feature in L. casei/rhamnosus. srtA1 is probably the housekeeping sortase, while the function of srtA2, which is only present in strains very close to BL23 (BL101, BL106), as a pseudogene in ATCC334 and plasmid encoded in LC705 is intriguing. 


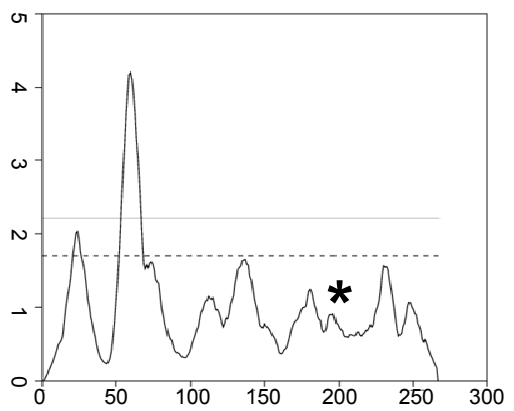

SrtA1

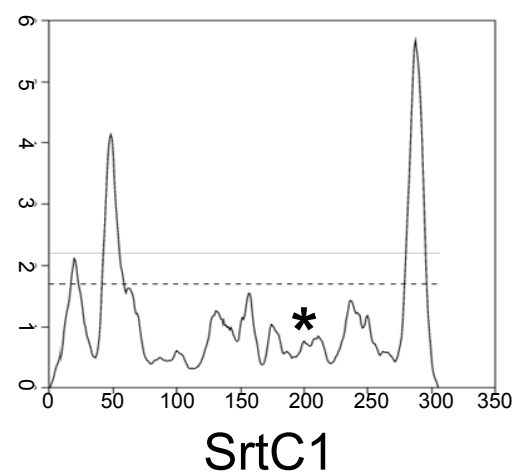

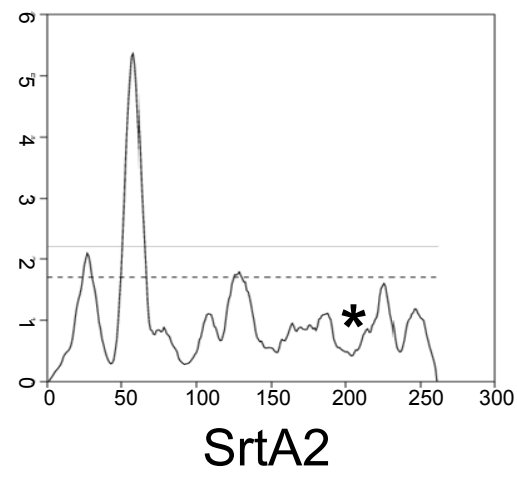

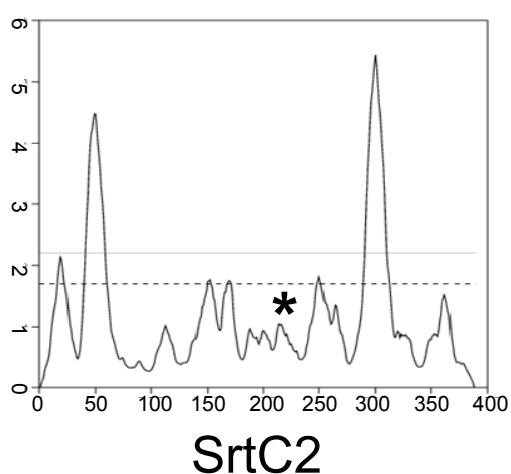

Figure 1. Hydropathy profiles in L. casei BL23 sortases. The hydrophilicity/hydrophobicity of the protein were computed according to the Dense Alignment Surface method (DAS server, http://www.sbc.su.se/ miklos/DAS/)(Cserzo, et al., 1997). Class A sortases (SrtA1 and SrtA2) carry an N-terminal signal peptide, whereas class C sortases ( $\mathrm{SrtC1}$ and srtC2) carry an additional $\mathrm{C}$-terminal hydrophobic region that could serve as a membrane anchor. The dashed lines indicate a loose cutoff, while the straight lines represent a strict one. The position of the critical catalytic cysteyl residue present in every sequence is indicated by an asterisk symbol. 


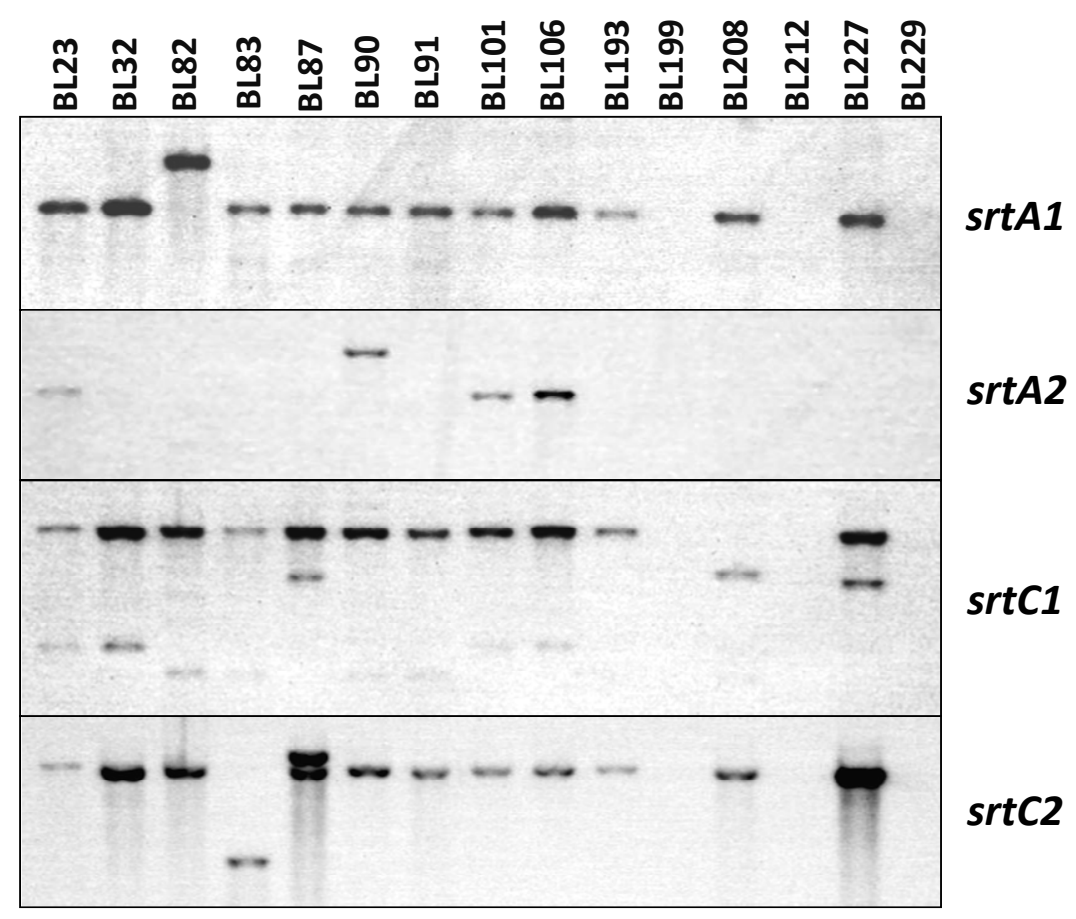

Figure 2. Screening by Southern blot on genomic DNA from a collection of $L$. casei strains digested with HindIII for the presence of homologues of the sortase genes.

\section{Putative sortase substrates in L. casei BL23.}

The HMM pf00746 (Gram-positive anchor) allowed the identification of 23 putative sortase substrates encoded in the $L$. casei BL23 genome (Table 4). The proteins destined to become attached to the peptidoglycan via the LPxTG anchor should also have an $\mathrm{N}$-terminal signal peptide with consensus cleavage motif AxAA for initial translocation of the protein across the cell membrane. Nevertheless, of the 23 putative sortase substrates identified, four did not appear to have such signal peptide (as predicted by SignalP).

Inspection of putative sortase substrate sequences showed that 11 contain the canonical LPXTG whereas the rest contain target sequences that deviate from it with one or more mismatches. 
One mismatch is present in eight cases, two mismatches in three cases and three mismatches in one case. The weblogo software (Crooks, et al., 2004) was used to visualize the conservation at each position of the motif and the relative frequency of the different residues (Figure 4). In summary, L. casei BL23 preferentially encode sortase substrates with cleavage motifs that does not deviate or that deviate slightly from the canonical one.

Of the 23 putative sortase substrates identified, $35 \%$ did not have any predicted function, $30 \%$ were predicted to have an enzymatic function, and $35 \%$ were predicted to have a surface adhesin/binding function (e.g., collagen-binding protein) based on the hints on a conserved domain database search (Marchler-Bauer, et al., 2011).

L. casei BL23 encodes three surface-anchored glycosidases that may be involved in the adaptation of this microorganism to exploit the carbohydrate resources present in the gastrointestinal niche (LCABL_02860, LCABL_28750 and LCABL_03600). LCABL_02860 is predicted to encode a $\beta-N$-acetylglucosaminidase enzyme of the glycosyl hydrolase family $20(\mathrm{GH} 20)$. These enzymes are involved in the removal of terminal $\beta$-glycosidically linked $N$-acetylhexosamine residues and participate in many important physiological and pathological processes (Intra, et al., 2008). They act hydrolyzing the $\beta$-1,6-linkages of PGA (Poly- $\beta-(1,6)-N$-acetylglucosamine), a major component of extracellular matrix polysaccharides and may act on the liberation of $\mathrm{N}$-acetylhexosamine residues from the highly glycosylated mucins from intestinal mucus or human milk oligosaccharides. LCABL_28750 encodes a glycosyl hydrolase of the GH31 family, putatively acting in the hydrolysis of glycosaminglycans from the extracellular matrix. LCABL_03600, also denoted fosE, encodes a $\beta$-fructosidase. It is localized in a putative levanase operon (lev) that includes a fructose/mannose phosphotransferase system (PTS) (fos $A B C D X)$ (Maze, et al., 2004). Its identification as a putative sortase substrate indicates that fructooligosaccharides (FOS) may be hydrolyzed extracellularly. 


\section{CAPÍTULO 5}

This may provide versatility for the utilization of larger prebiotic substrates in the gastrointestinal tract without dependence on dedicated transporters for their uptake. The BL23 fos operon has high sequence identity with the fOSABCDXE operon of $L$. paracasei 1195 (Goh, et al., 2007), where FosE was demonstrated to be cellwall associated and catalyze the extracellular hydrolysis of FOS and other fructose-containing carbohydrates.

Other genes encoding enzymatic functions are predicted to code for three cell envelope associated proteinases (CEP). CEPs are present in lactococci and several species of lactobacilli where they provide essential amino acids for growth, but also in some species of pathogenic streptococci where they most likely act as a virulence factors. Two are paralogous genes in tandem encoding PrtR proteases (LCABL_05320 and LCABL_05330) that share $43 \%$ sequence identity and one is a PrtP encoding gene (LCABL_24520). The composition of domains varied, but all contain the catalytic serine protease domain showing sequence homology to the active site of subtilases.

The prtP gene is associated with the upstream-located and divergently transcribed prtM gene (LCABL_19420) encoding the PrtM protein involved in the maturation of PrtP proteinase (Kunji, et al., 1996). Strahinic et al. performed a nucleotide sequence analysis of the prtM-prtP intergenic region of different strains ( $L$. casei BL23, $L$. casei ATCC 334, L. plantarum BGSJ3-18 and L. paracasei ssp. paracasei NCDO 151) that revealed over $97 \%$ sequence homology among strains, indicating the presence of an identically organized proteinase region (Strahinic, et al., 2010). The orthologue genes of the PrtR proteases in the highly homologous L. casei ATCC334 strain (LSEI_0465 and LSEI_0468) are truncated which could be in agreement with an adaptation to a simpler ecological niche. ATCC 334 strain is a cheese isolate and it may rely on another strain of greater proteolytic potential for its growth on milk. 
At least five proteins among the identified putative sortase substrates contain domains present in the $S$. aureus CNA collagen adhesin (LCABL_05200 and LCABL_05220 in the srtC2 cluster; LCABL_25400 and LCABL_25420 in the srtC1 cluster and LCABL_26030). CNA is a MSCRAMM (Microbial surface component recognizing adhesive matrix molecules) and virulence factor in $S$. aureus necessary and sufficient to mediate the attachment to collagen containing substrates. All the proteins mentioned contain a Cna-B domain. The absence of this B domain did not affect processing of the collagen adhesin to the cell surface or the ability to bind collagen; it has been proposed to serve as a stalk that projects the adhesive Cna-A domain (Snodgrass, et al., 1999). A Cna-A domain is found in LCABL_26030. Mutation experiments performed on the CnaA domain of the staphylococcal CNA confirmed that it contains residues critical for collagen adhesion and a groove present in its crystal structure showed surface complementarity to collagen probes (Symersky, et al., 1997). L. casei BL23 shows protein-dependent collagen binding (Munoz-Provencio, et al., 2009) but the role of these proteins in adhesion to extracellular matrix proteins is presently unknown.

Sortases belonging to the $\mathrm{C}$ class and their substrates are often encoded in gene clusters and genome context seems a strong indicator of functional relationship. That is the case for $L$. casei BL23 srtC1 and srtC2 which are included in clusters that contain three putative substrates each (Figure 3 ). This kind of sortase-substrate clustering might represent an independent functional unit encoding cell surface-associated proteins along with sortase enzymes exclusively dedicated to the cell wall anchoring of those proteins. This idea was reinforced by the fact that in the SrtC1 and SrtC2 putative substrates a glycine residue follows the LPXTG motif, which is characteristic for substrates being anchored by this class of sortases (Desvaux, et al., 2006). 


\section{CAPÍTULO 5}

The automated annotation of the genome revealed that both clusters contain proteins homologue to those encoded in the biofilm enhancer locus bee of Enterococcus faecalis (Tendolkar, et al., 2006, Schluter, et al., 2009). In E. faecalis the bee locus is comprised of three structural genes bee-1, bee-2 and bee-3 which encode sortase substrates and two sortase genes. It is likely harbored in a conjugative plasmid that enhances the biofilm formation capacity upon transconjugation (Tendolkar, et al., 2006). A bee-2 homologue is present in the srtC2 cluster and a bee-3 homologue is located in the srtC1 cluster.

However, the highest homology of the srtC1 and srtC2 clusters was for the spaFED and spaCBA clusters recently described in L. rhamnosus GG, with identity levels at the nucleotide level of $69 \%$ and $96 \%$, respectively. Those clusters also carry a C-class sortase along with three structural genes encoding pilin subunits each. The roles of the different pilin subunits were predicted based on amino acid sequence analysis with pilins from related Gram-positive species (Kankainen, et al., 2009). SpaA and SpaD were predicted to be major pilin subunits forming the shaft. SpaB and SpaE would be ancillary minor pilin subunits present at the pilus base signaling the cessation of polymerization and decorating the backbone. Finally, SpaC and SpaF represent another kind of larger minor pilin subunits with adhesive properties localized along the backbone and at the pilus tip.

The pilin subunits of $L$. rhamnosus GG SpaB, SpaC and SpaF, wich are $97 \%, 94 \%$ and $62 \%$ identical to the proteins encoded by LCABL_05210, LCABL_05200 and LCABL_25420 respectively, bind to intestinal mucus. The binding is mediated through a possible lectintype binding capacity provided by the von Willebrand factor domain present in the primary structure of $\mathrm{SpaC}$ and through electrostatic contacts of the positively charged SpaB with the negatively charged mucosal substrate. SpaF tough showing significant adherence to the mucosal substrate lacks any similar or related domain to the von Willebrand factor like one present in SpaC and the possible binding mechanism is still to be determined (von Ossowski, et al., 2010). 
In this type of pili, the sortase reaction covalently bind the pilin subunits by isopeptidyl bonds that serve as a polymerization mechanisms for pili extension, while its basal portion is anchored to the surface by the housekeeping sortase.

In contrast to other lactobacilli from intestinal origin, the presence of proteins with tandem multiple mucin-binding domains (MucBP) involved in mucus attachment is not a characteristic of $L$. casei. The product of LCABL_25040, another sortase substrate, represents the only exception. Although it does not show homology to mucus binding proteins such as Msa or Mub from Lactobacillus plantarum and Lactobacillus reuteri, it carries three MucBP domains. It was annotated as internalin $J$ due to the shared sequence similarity with the Pfam-MucBP domain repeats found typically in that protein family exclusive to the food-borne pathogen Listeria monocytogenes but it lacks the typical internalin domain responsible for mediating protein-protein interactions in the infection process of $L$. monocytogenes (Sabet, et al., 2005). It shares a 38\% identity at the amino acid level with the mucus-binding factor (MBF) protein encoded by the L. rhamnosus GG LGG_02337 ORF. The MBF protein has been recently proven to be surface localized in $L$. rhamnosus GG and its purified recombinant form was able to bind intestinal mucus in vitro, although less strongly than the SpaC pilin subunit. It was hypothesized to account only for a small fraction of the mucusbinding capacity in a piliated microbe requiring a close proximity between the bacterial surface and the mucus (von Ossowski, et al., 2011).

In summary, although the specific function of most of the putative sortase substrates is unknown, sequence analysis suggests that many of them are related to the lifestyle of $L$. casei at the host mucosal surfaces and most likely participate in adhesion to host components or play a key role in substrate release from environmental macromolecules. 


\section{CAPÍTULO 5}

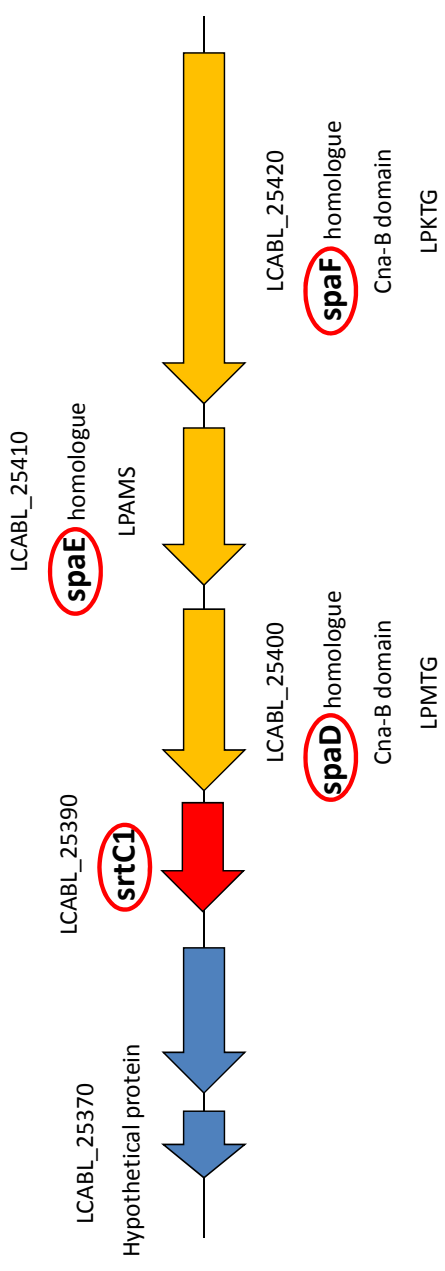

Iวมน

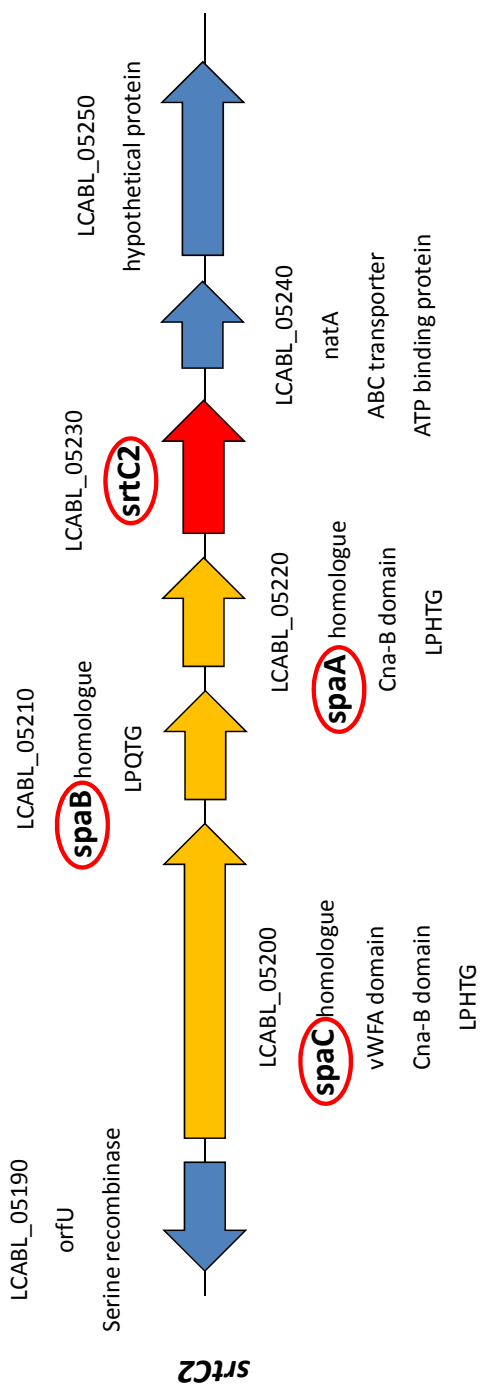

Figure 3. Genomic context of the L. casei BL23 class C sortases. The red arrows indicate the sortase genes, while the orange colored ones indicate putative sortase substrates. The locus tags are indicated along with some relevant characteristics as known homologues, conserved domains or sortase cleavage motifs sequences if present. 


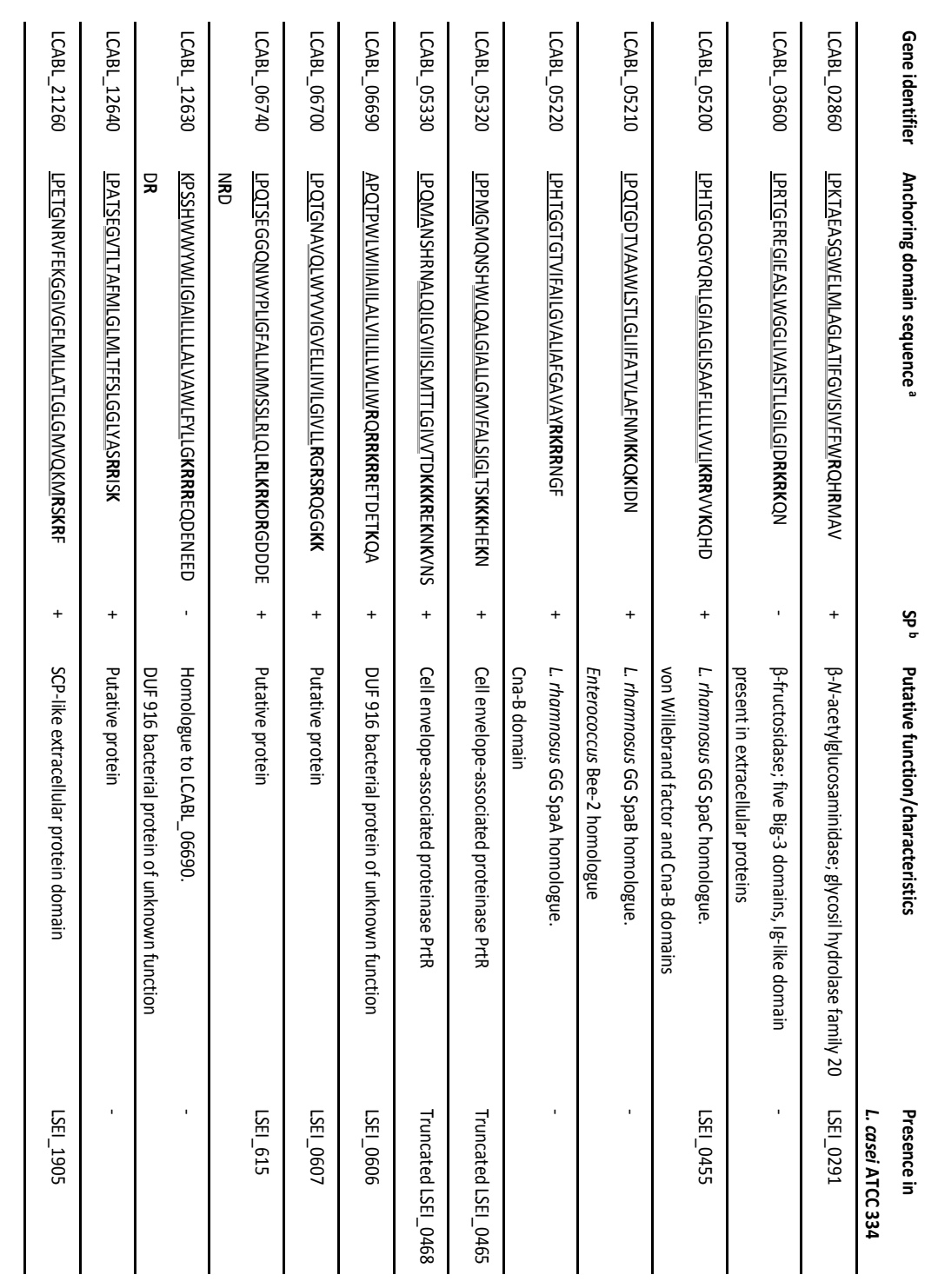

Table 4. L. casei BL23 genes encoding proteins putatively anchored to the cell wall by a sortase-dependent mechanism.

a LPXTG consensus motifs and the following amino acid are single underlined, transmembrane domains predicted using the TMHMM server (24) are double underlined, and cationic residues are in boldface.

${ }^{\mathrm{b}}$ SP, signal peptides were predicted using SignalP3.0 (2). + present; - absent. 
CAPÍTULO 5

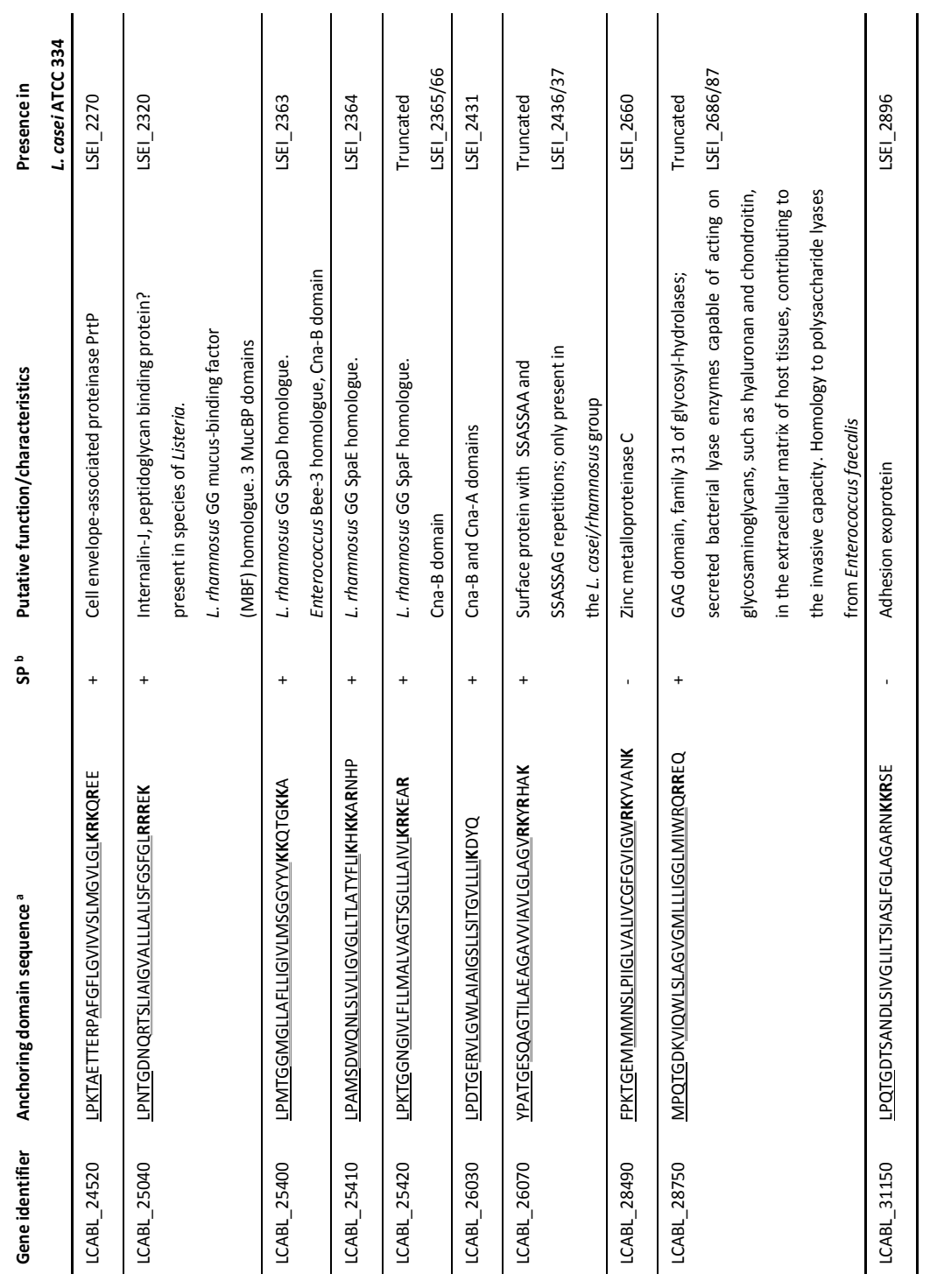

Table 4. continued 


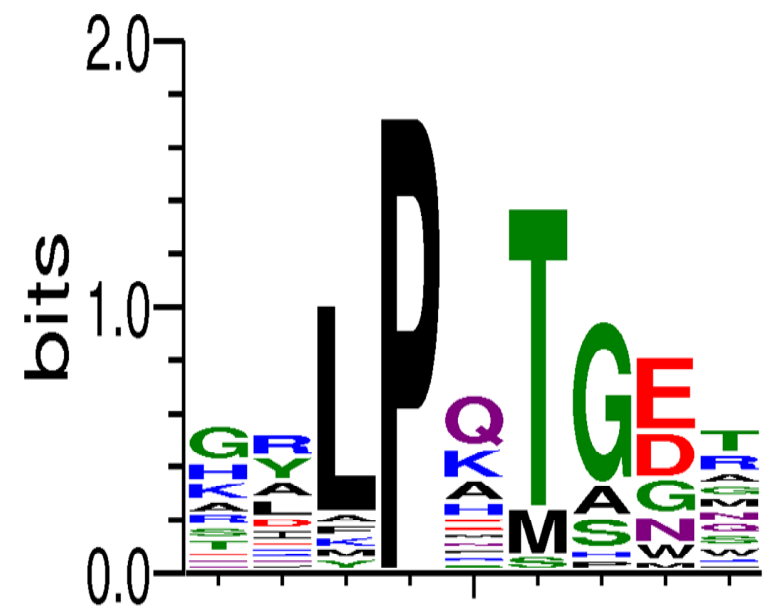

Figure 4. The consensus sortase cleavage site of L. casei BL23 (LPxTG, found in 11 of 23 predicted sortase substrates). The overall height of each stack indicates the sequence conservation at that position (measured in bits), whereas the height of symbols within the stack reflects the relative frequency of the corresponding amino acid at that position. The Weblogo software (Crooks, et al., 2004) was used to visualize the motifs.

\section{Construction of mutants in L. casei BL23 sortases.}

Single mutant in all sortase encoding genes were constructed by inserting non-replicative plasmids ( $p R V 300, p U C m 1)$ carrying internal fragments of the genes (Table 1 and Figure $5 \mathrm{~A}$ ). A double mutant in srtA1 and srtA2 (strain BL345) was also constructed by deleting the srtA2 gene (Figure $5 B$ ) followed by insertional inactivation of srtA1. The mutant strains were assayed for their growth in MRS medium, showing no changes in growth rate compared to the parental BL23 strain (data not shown). 
CAPÍTULO 5

1

Figure 5A
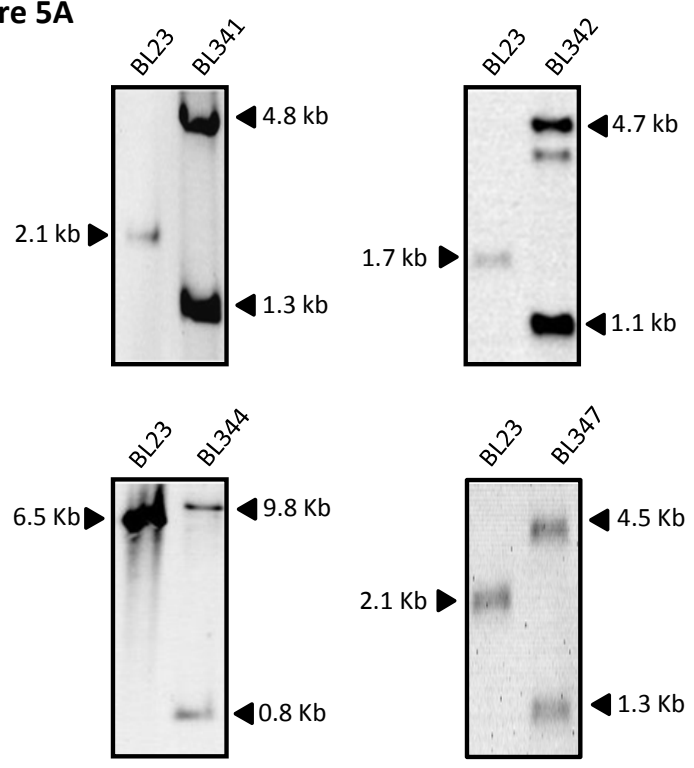

4

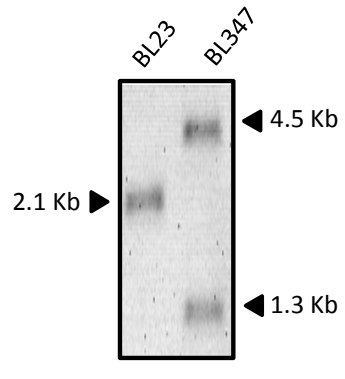

5
3
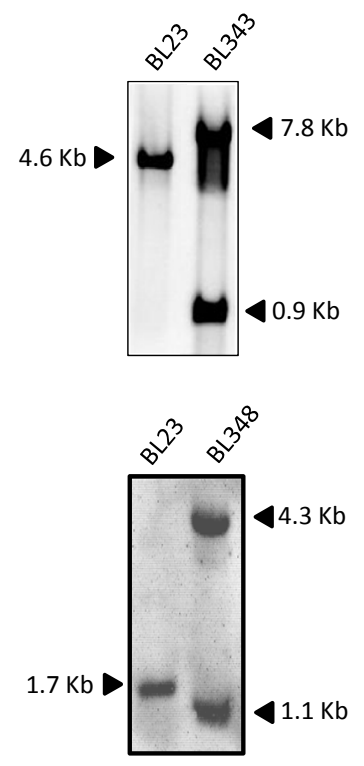

6

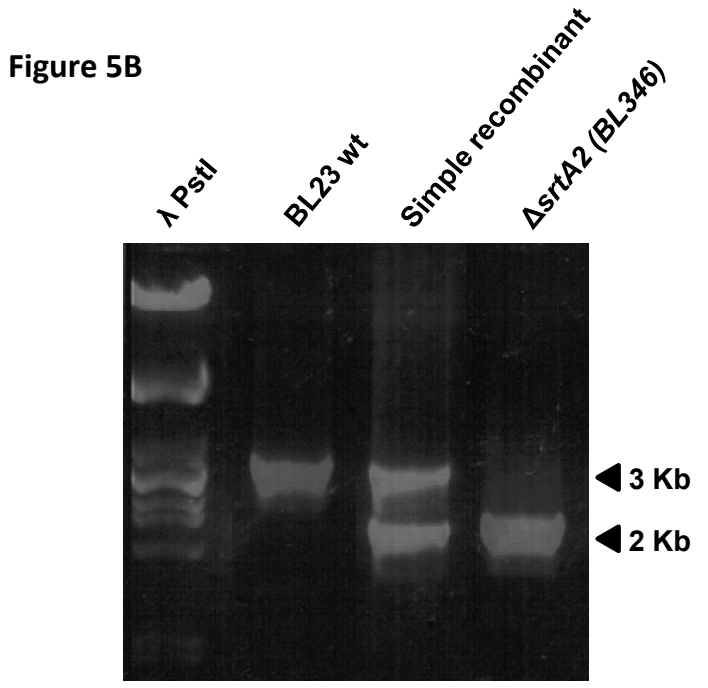


Figure 5. Construction of $L$. casei BL23 mutants in the sortase genes. Wildtype strain was transformed with the non-replicative plasmids pRVsrtA1, pRVsrtA2, pRVsrtC1, pRVsrtC2, pUCsrtA1 or pUCsrtA2 and erythromycinresistant colonies in the first four cases and chloramphenicol-resistant colonies in the last two cases were selected. 5A. Integration at the correct loci was verified by Southern blot on HindIII-digested genomic DNA in 1, 4 and 5; by Southern blot on Accl-digested genomic DNA in 2 and 6 and on Kpnl-digested genomic DNA in 3 from wild-type strain (BL23) and the disrupted mutants. 5B. Deletion of srtA2 was verified by PCR using the primer pair A2_PRE_FOR and A2_POST_REV. The absence of srtA2 (LCABL_06160) was also verified by a negative amplification using the primer pair SRTA2_FOR and SRTA2_REV (data not shown).

\section{Characterization of the effect of sortase mutations in L. casei}

\section{Cell surface characteristics}

The net hydrophobicity and the surface charge are among the most commonly studied physicochemical properties of the bacterial surface. They determine to a large extent the non-specific interactions with the environment. We used the microbial adhesion to solvents test (MATS) to measure surface characteristics in L. casei strains by measuring affinity to chloroform (acidic solvent and electron acceptor), ethyl-acetate (basic solvent and electron donor) and hexadecane (hydrophobic solvent) (Figure 6) (Bellon-Fontaine, 1996).

The high adhesion to the acidic solvent chloroform (above 95\%) and the low adhesion to the basic solvent ethyl acetate (around $21 \%$ ) in all the strains with no statistically significant differences confirm the non-acidic character of the L. casei BL23, as already reported (Munoz-Provencio, et al., 2009). Percentages of adherence to the apolar solvent hexadecane varied among strains. L. casei BL23 wild type is highly hydrophobic ( $58 \%$ adhesion to hexadecane) and three mutant strains, srtA1, srtC1 and the double mutant srtA1/srtA2 experiment a reduction in hexadecane adhesion of $77 \%, 59 \%$ and $79 \%$, respectively, although only changes in srtA1 and the double 


\section{CAPÍTULO 5}

mutant strains were significant ( $\mathrm{P}=0.0284$ and $\mathrm{P}=0.048$, respectively). This suggests that the surface hydrophobicity of $L$. casei BL23 is influenced by proteins anchored by sortase-dependent mechanisms.

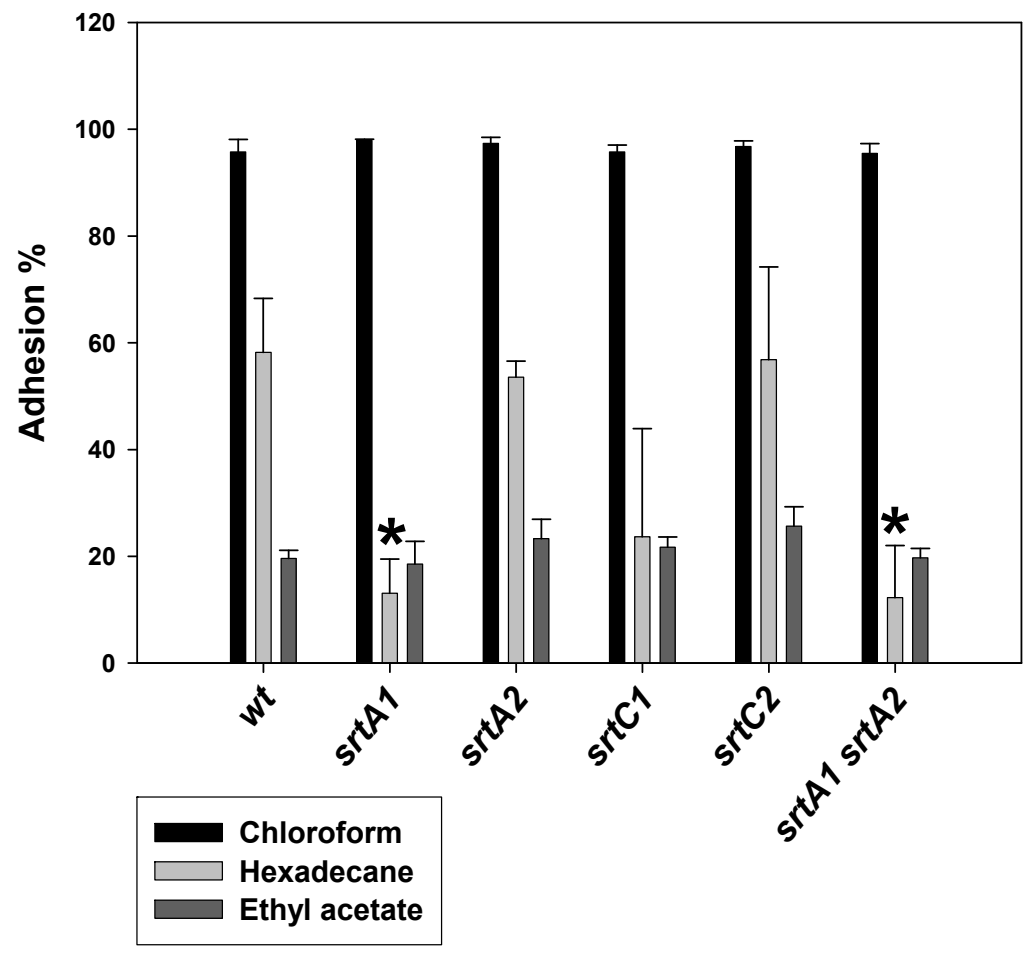

Figure 6. Cell-surface characteristics of $L$. casei wild type (BL23) and the sortase mutants (BL341, BL342, BL343, BL344 and BL345) measured by the MATS test. The bars represent standard deviations. An asterisk indicates a statistically significant difference according to the t-test $(p<0.05)$. 


\section{CAPÍTULO 5}

\section{Adhesion properties of $s r t$ mutants}

First, we measured adhesion of the strains to cultured intestinal epithelial cells lines. The adhesion profile resulted to be quite similar for the two cell lines employed, so are the absolute values. A significant decrease of $83 \%$ in adhesion to the HT-29 cell line was observed in the srtA1/srtA2 double mutant strain with respect to the parent strain $B L 23\left(P=7,508 * 10^{-3}\right)$ (Figure $\left.7 A\right)$. Significant changes were also detected in the binding ability to Caco2 with decreases of $44 \%$ for the srtA2 mutant $\left(P=6,628 * 10^{-3}\right)$ and $66 \%$ for the double mutant srtA1/srtA2 $\left(P=9,296 * 10^{-5}\right)$ with respect to the wild type (Figure 7B).

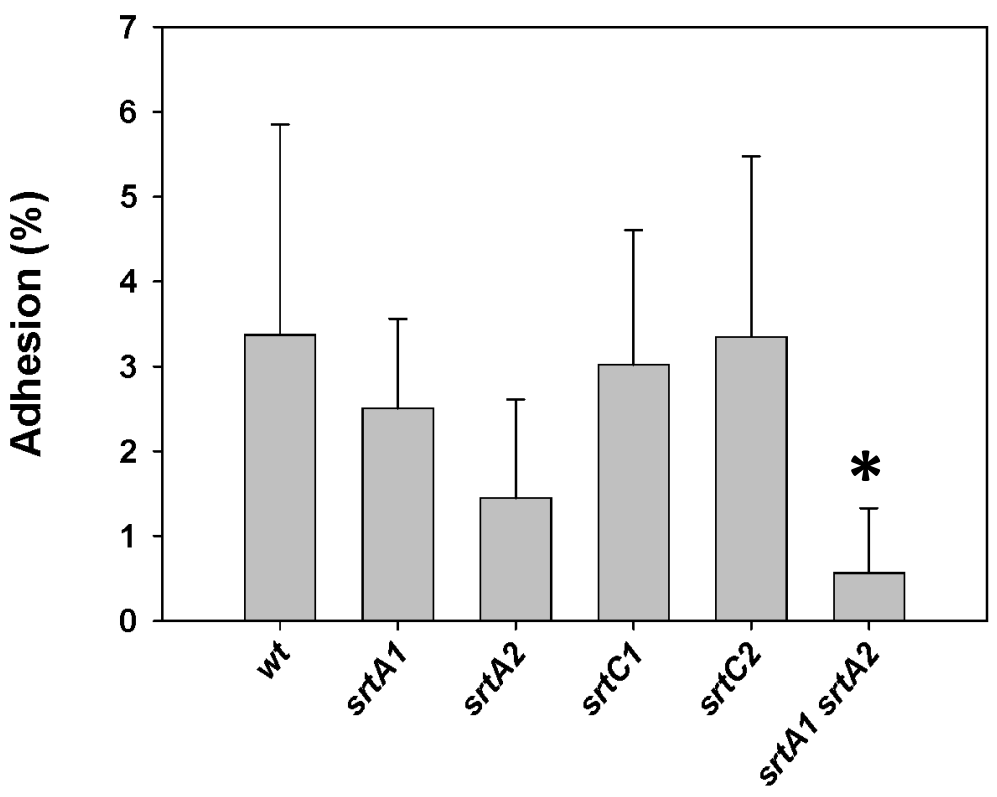

Figure 7A. Binding of $L$. casei BL23 wild type and the sortase mutants to HT29 cells. The bars represent standard deviations. An aterisk indicates a statistically significant difference according to the t-test $(P<0.05)$. 


\section{CAPÍTULO 5}

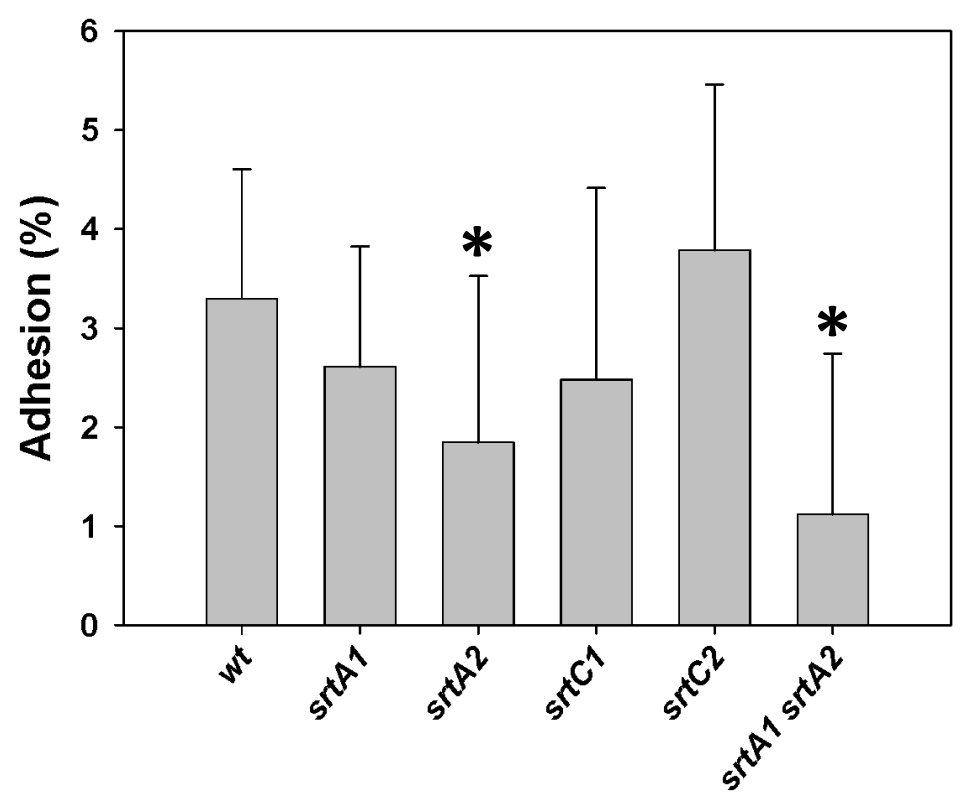

Figure 7B. Binding of L. casei BL23 wild type and the sortase mutants to Caco- 2 cells. The bars represent standard deviations. An asterisk indicates a statistically significant difference according to the t-test $(P<0.05)$.

We also measured the binding to three extracellular matrix proteins (collagen, fibronectin and fibrinogen) immobilized on the surface of immunoplates. L. casei strains adhere to the three substrates. No statistically significant differences were found between $L$. casei BL23 wild type and the sortase mutants in the adhesion to collagen or fibronectin. In contrast, srtC1 and the double mutant srtA1/srtA2 showed a statistically significant decrease in adhesion to fibrinogen of $46 \%(P=0.021)$ and $49 \%\left(P=9.775^{*} 10^{-3}\right)$, respectively. 


\section{Determination of enzymatic activities}

We determined the activity in whole cells of two enzymes that are putative substrates for sortase enzymes (the $\mathrm{N}$ acetylglucosaminidase and the cell envelope proteinase encoded by LCABL_02860 and LCABL_24520, respectively, Table 4) in the wild type and the different srt mutants. A statistically significant decrease in $N$-acetylglucosaminidase activity by $18 \%\left(\mathrm{P}=2.7753 * 10^{-4}\right)$ was found in srtA1. This activity was additionally lowered by $62 \%$ $\left(\mathrm{P}=2.390^{*} 10^{-8}\right)$ in the class $\mathrm{A}$ sortase double mutant srtA1/srtA2 (Figure 8).

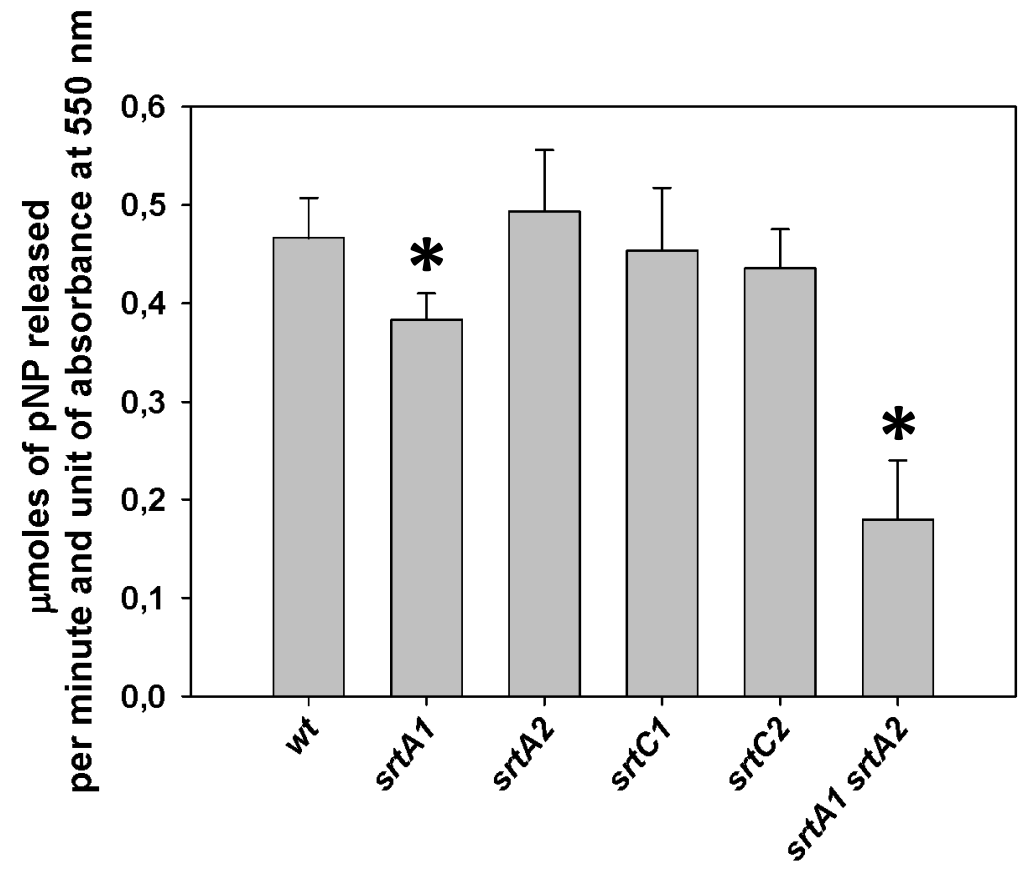

Figure 8. $N$-acetylglucosaminidase assay. Measure of the $N$-acetyl- $\beta$-Dglucosaminidase activity of $L$. casei BL23 wild type and the sortase mutants. 


\section{CAPÍTULO 5}

The bars represent standard deviations. An asterisk indicates a statistically significant difference according to the t-test $(P<0.05)$.

The surface proteinase activity was determined by monitoring its proteolytic activity on $\beta$-casein by electrophoresis of the resulting peptides. The hydrolytic activity of $L$. casei BL23 on this substrate was low and only detectable after long incubation periods. The single srt mutants showed hydrolytic activity comparable to that of the wild type, whereas a reduced $\beta$-casein hydrolysis was observed for the srtA1/srtA2 strain (Figure 9).

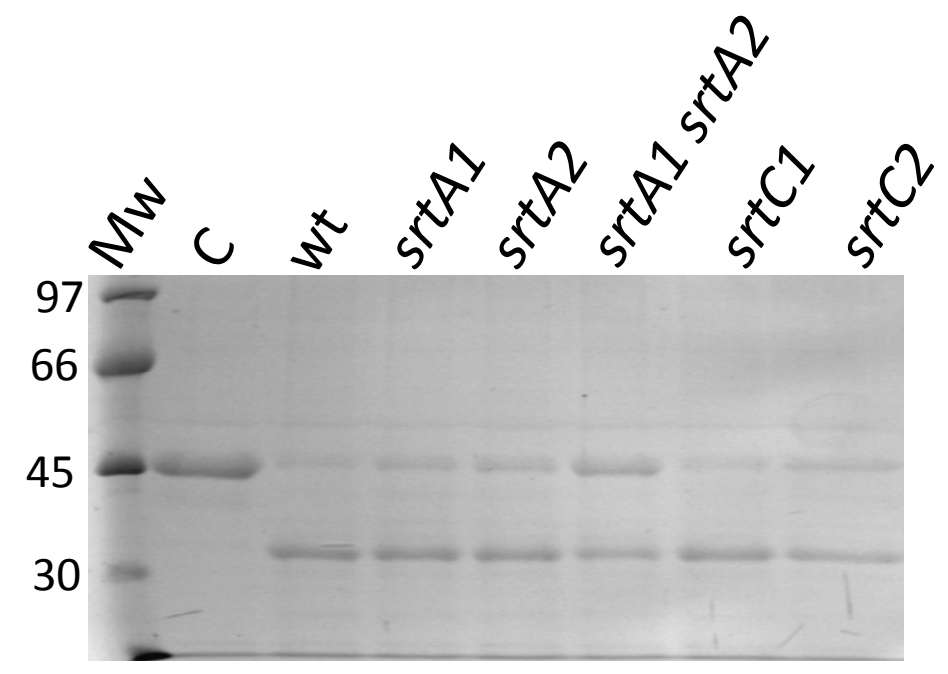

Figure 9. Proteolytic activity of whole cells towards $\beta$-casein determined by SDS-PAGE analysis. After an overnight incubation at $37{ }^{\circ} \mathrm{C}$, aliquots were loaded onto SDS-PAGE gels and Coomassie stained. $\mathrm{Mw}$ is a molecular weight protein standard; numbers on the left are molecular weight in $\mathrm{kDa}$; $\mathrm{C}$ is a control $\beta$-casein sample incubated without cells; wt accounts for BL23 strain (wild type). 
Anchoring of a heterologous protein to the $L$. casei surface.

We used a reporter protein to assess the surface anchoring activity present in srtA1 and srtA2 mutants. To this end, two mutant strains disrupted in srtA1 and srtA2 and carrying a chloramphenicol resistance marker (Table 1 and Figure 5) were transformed with the pNucA-CWA plasmid, which encoded the staphylococcal nuclease fused to the cell-wall anchoring domain of the S. pyogenes M6 protein. The plasmid was also introduced in the srtA1/srtA2 double mutant and the presence of NucA in cell culture supernatants and surface fractions was assayed by Western blot analysis (Figure 10). NucA bands of the same size were detected in surface fractions of all strains, but their intensity decreased in the sortase mutants as follows: wt>srtA2>srtA1>srtA1/srtA2. When the culture supernatants were analyzed, the srtA1 mutation, and to a lesser extent the srtA2 mutation, resulted in the occurrence of NucA forms of a higher size which could correspond to non-processed LPXTG fusions. These results are congruent with the lack of a transpeptidase reaction at the LPXTG sequence, which resulted in lack of cleavage of the Cterminal part of the anchoring sequence $(3.17 \mathrm{kDa}$ in the $\mathrm{M} 6$ anchoring domain fused to NucA). The intensity of the NucA bands in supernantants followed the gradation srtA1/srtA2>srtA1>srtA2>wt, additionally suggesting that in the absence of sortase activity more NucA protein is released to the supernatant.

\section{Transcriptional analysis of sortase genes}

In order to determine whether the class $A$ sortase genes (LCABL_23200, LCABL_06160) and the class C sortase genes (LCABL_25390, LCABL_05230) were expressed under our laboratory conditions we examined their transcription by RT-PCR analysis. These experiments evidenced the presence of RNA transcripts for the LCABL_23200 (srtA1), LCABL_25390 (srtC1) and LCABL_05230 (srtC2) open reading frames in the wild type and for LCABL_06160 (srtA2) in 


\section{CAPÍTULO 5}

the srtA1 mutant (Figure 11). srtA1, srtC1 and srtC2 were clearly expressed, while the srtA2 CDNA was barely amplified and only became evident when srtA1 was mutated.

These results suggest a complementary function of the two class $A$ sortase transpeptidases of this organism and suggest that part of the SrtA1 functions can be supplied by SrtA2 when the former enzyme is absent.

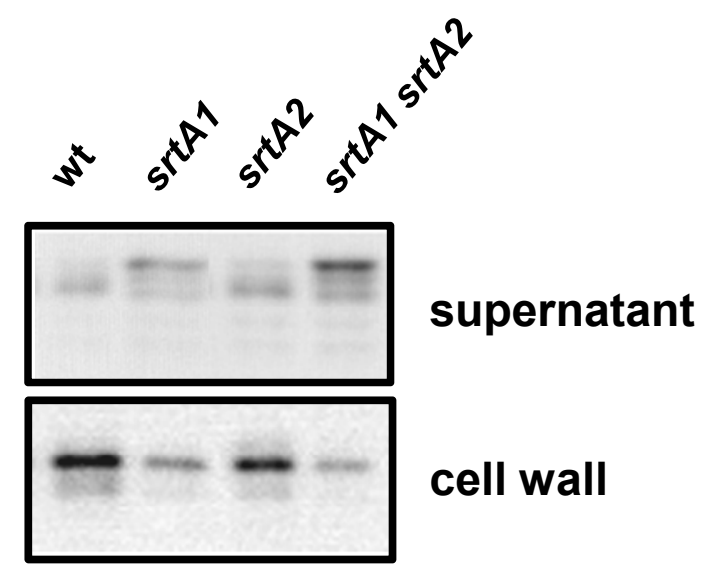

Figure 10. Western blot detection of Nuc reporter fusions in the supernatant and cell wall fractions of $L$. casei wild type (BL23) and the different sortase mutants. $0.5 \mu \mathrm{g}$ of cell-envelope fraction proteins or $0.5 \mu \mathrm{l}$ of supernatant/conditioned media were loaded onto each lane. Cell wall= surface proteins from the cell-envelope (cell-wall/membrane fraction); supernatant $=$ proteins present in the conditioned medium.

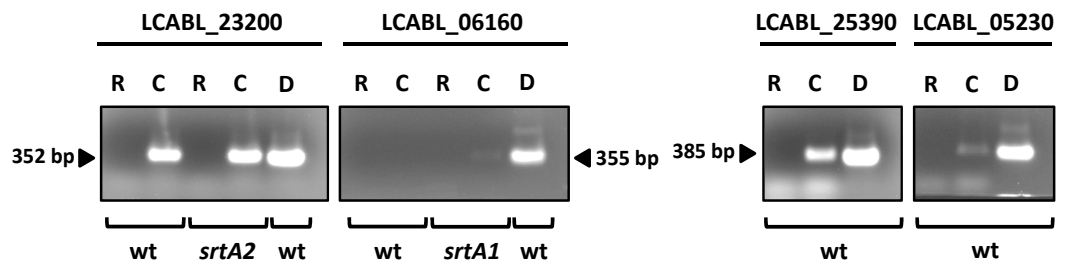

Figure 11. RT-PCR analysis of the expression of LCABL_23200, LCABL_06160, LCABL_25390 and LCABL_05230 in L. casei BL23 wild type and sortase mutants. PCR was performed with RNA samples (lanes R); cDNA samples (lanes C) and chromosomal DNA (lanes D) as template. wt= BL23 wild type, 
CAPÍTULO 5

srtA1=LCABL_23200::pRV300 (BL341) and srtA2=LCABL_06160::pRV300 (BL342). 


\section{CAPÍTULO 5}

DISCUSSION

Sortase enzymes have attracted attention as a possible new anti-infective target with a lesser tendency to develop resistance (Suree, et al., 2009, Lee, et al., 2010). Nevertheless, the sortase dependent surface proteins are key to many processes related with niche adaptation and persistence in pathogenic and non-pathogenic Gram-positive bacteria. It is important to determine the traits that the commensal and probiotic microorganisms share with the pathogens to gain a better understanding on the mechanism that promote health and to exclude any unwanted side effects of the sortase based anti-infective therapies.

As a general rule, mutants in sortase genes showed a bacterial morphology and growth kinetics similar to those of their parental strains. This has been reported for sortase mutants of different classes in many Gram-positive microorganisms including LAB. That is the case for the different mutants of $L$. casei BL23 obtained in this study and also for the srtA deletion mutant in the model LAB L. lactis (Dieye, et al., 2010). Only in the case of Bacillus anthracis class $B$ sortase and under iron-limiting conditions significant growth defects have been detected (Maresso, et al., 2006). This suggest that the absence of the sortase activity may be less critical than the absence of other enzymatic activities essential for life processes (Clancy, et al., 2010).

The 23 putative sortase substrates identified in the $L$. casei BL23 genome, account for $0.77 \%$ of its exoproteome, which is quite similar to the $0.78 \%$ in the closely related L. casei ATCC334 strain. Those strains were among the LAB with higher percentage of sortase substrates in a genome-scale comparative analysis carried out with 26 strains by Zhou and coworkers (Zhou, et al., 2010). The absence in some L. casei strains (e.g. ATCC334) of some functional genes related to adhesion (SpaB, SpaC and SpaF) or with scavenging functions (PrtR, $\beta$-fructosidase) may reflect the absence of selective pressure due to the adaptation to a more specific environment (milk instead of gastrointestinal tract). 
Similarly, in Lactobacillus salivarius UCC118 six out of the ten sortase substrates identified are pseudogenes or gene fragments. Most of them would code for functions related to adhesion in the oral cavity, suggesting that this strain suffered an adaptation that was concomitant with the loss of functions related to adhesion (van Pijkeren, et al., 2006). The GC content of the sortase dependent protein ORFs in L. salivarius UCC118 was on average $5 \%$ higher than that of the chromosome, with two genes even differing in more than $30 \%$ from the average genomic GC content. This was attributed to a possible horizontal gene transfer acquisition (van Pijkeren, et al., 2006). By contrast in L. casei BL23 the average difference in GC content was only of $1.63 \%$ with only four uncharacterized proteins having a difference of up to $4-5 \%$ higher content. That could account for a more distant acquisition.

The existence of two class-A sortases in the BL23 strain is remarkable. The fact that the srtA2 homologue in L. rhamnosus Lc705 is plasmid-encoded leaves open the possibility of srtA2 locus being an integrated plasmid remnant in strains like BL23, where it is chromosomally located. The exact role of SrtA2 is still unknown and the fact that its transcription was only evidenced upon srtA1 mutation suggests that srtA2 transcription could be activated when there is a lack of general sortase activity.

We have shown that the activity of the class A sortases is necessary for the anchoring of at least an $\mathrm{N}$-acetylglucosaminidase and the cell-wall proteinase in L. casei BL23 and that they can anchor NucA fused to an heterologous sorting sequence. Although we found a decrease in the surface display of these three reporters in the srtA1 strain and even a more pronounced effect in the srtA1/srtA2 double mutant, there was never a complete lack of anchoring. This is in contrast to recent results obtained in L. lactis, where a srtA mutation completely abolished the anchoring to the cell wall of all the sortase substrates tested. Therefore, as reported for many other Grampositive bacteria, srtA is the single gene responsible for the general sortase activity in L. lactis (Dieye, et al., 2010) 


\section{CAPÍTULO 5}

Also, Dieye and coworkers used two-dimensional gel electrophoresis of surface proteins to search for proteins absent in the L. lactis srtA mutant, and they identified several sortase substrates (Dieye, et al., 2010). However, and in agreement with the results of surface anchoring, our efforts to detect the absence/reduction of surface proteins in the BL23 srtA1/srtA2 mutant by this technique were not successful (data not shown).

The absence of the sortase A activity in L. casei BL23 might be compensated by another sortase activity or its substrates might be anchored, transiently at least, to the cell wall by a sortaseindependent mechanism. It is tempting to speculate that SrtC1 or SrtC2 sortases may be responsible for some anchoring capacity and partially compensate the absence of the housekeeping sortases. The class $C$ sortases usually act as pili polymerizing enzymes and they catalyze the cross-linking of pilin protein subunits forming the proteinaceous appendixes, using two peptides instead of using a protein and the peptidoglycan as substrates. However, some pilus associated sortases, such as those from Streptococcus pyogenes, belong to the B class (Dramsi, et al., 2008). Also, in L. casei BL23 the sorting signals present in the proteins encoded in the class $C$ sortase clusters do not differ from the LPXTG sequence characteristic to class A substrates. Construction of multiple deleted mutant strains will help to answer this question.

Adhesion experiments indicate that one or more sortasedependent proteins are involved in the adhesion to human intestinal epithelial cells in BL23. This is in agreement with the presence of putative sortase substrates with likely adhesion functions such as the proteins encoded by the spaCBA and spaFED clusters, LCABL_25040 or LCABL_26030. In experiments carried out in L. salivarius UCC118, a sortase A mutant experimented a reduction in the adherence to intestinal epithelial cells HT-29 and Caco-2 (van Pijkeren, et al., 2006). The reduction was lesser for the adhesion to Caco-2 cells. The authors attributed the differences observed to a possible presence of more abundant receptors for sortase independent adhesins or to the absence of MUC3 mucin on the surface of that cell line. 
In our work the level of adhesion was quite similar for the two cell lines, but it was coincidental with a slightly lesser reduction in the adhesion to Caco-2 cell line.

A previous work determined that the protein contribution to the binding to extracellular matrix molecules (collagen, fibronectin and fibrinogen) was important in L. casei BL23 (Munoz-Provencio, et al., 2009). Studies carried out in pathogenic Gram-positive microorganisms determined the importance of the sortase reaction in anchoring important adhesins. The mutation of the general sortase SrtA or use of inhibitors produced impairment in binding to major extracellular matrix components, to intestinal epithelial cells and in clumping to fibrinogen (Lalioui, et al., 2005, Park, et al., 2005, Kang, et al., 2006, Oh, et al., 2006). For the L. casei BL23 sortase mutants, statistically significant decreases in adhesion were only detected in the case of fibrinogen. That may imply that the surface proteins responsible for the binding to the other ECM mentioned in L. casei BL23 would be anchored and surface exposed by a sortaseindependent mechanism. This is supported by previous findings in which proteins able to interact with fibronectin and collagen and with no known export or surface anchoring sequences were identified in $L$. casei BL23 (Munoz-Provencio, et al., 2010, Munoz-Provencio \& Monedero, 2011). The contribution of those proteins may be important in the adhesion phenomena and would not be affected by the mutation of sortase genes.

L. rhamnosus GG strain is a well characterized probiotic with an important adherence to human intestinal mucus (Alander, et al., 1999). Genetic and biochemical analyses revealed the presence of multiple factors responsible for this, including the MabA (Velez, et al., 2010) and MBF (von Ossowski, et al., 2011) proteins and the pili encoded by the spaCBA operon (Kankainen, et al., 2009) (von Ossowski, et al., 2010). This strain is the first probiotic LAB where mucus adhesive pili formed by the SpaCBA subunits have been detected. Our findings indicate that $L$. casei BL23, which contains a spaCBA homologue operon clustered with srtC2, may be another piliated LAB as well. 


\section{CAPÍTULO 5}

In addition, genome and Southern blot data indicate that the presence of at least one of these pili-encoding clusters is a general feature of the L. casei/L. rhamnosus group. In spite of the presence of pili clusters and a homologue to MBF from L. rhamnosus GG, L. casei BL23 showed very low binding to pig gastric mucin, while showing one of the highest binding capacities to human colonic resected fragments in a collection of $L$. casei strains (Munoz-Provencio, et al., 2009). The outermost layer of the intestinal mucosa present in these fragment is the highly glycosylated mucus layer. The differences in the methodologies of assays make difficult to compare the adhesion in absolute terms, but the absence of mucin binding in L. casei BL23 could be due to the different mucin source (gastric instead of colonic and pig instead of human).

It should be noted that adhesion of lactobacilli to the gastrointestinal mucosa is a result of multifactorial interactions. The adhesive capacity is considered important to prolong the persistence and avoid an immediate washout in the highly dynamic intestine environment with its peristaltic movement and epithelial cells turnover. The pili, due to their length, probably mediate the first steps of the interaction between the bacterial surface and the mucosal surface and once the surfaces become closer other factors could gain importance. To compare the adhesion levels of $L$. rhamnosus GG and L. casei BL23 a standardized experimental setting should be used.

In summary, in L. casei BL23 more that twenty proteins are likely anchored to the cell surface by sortases and they would play roles in adhesive and substrate scavenging processes, which would account for an adaptation to persist in the gastrointestinal niche. SrtA1 is the housekeeping sortase in this strain, while SrtA2 can compensate its absence to a certain extent. The genes for two other sortases, srtC2 and srtC2, are clustered with genes putatively encoding adhesive pili assembled by sortase-catalyzed reactions. The presence of pilus-like structures has only been reported for $L$. rhamnosus GG, but it may constitute a characteristic for the $L$. casei/rhamnosus group. 


\section{ACKNOWLEDGEMENTS}

This work was supported by projects AGL2004-00176/ALI and Consolider Fun-c-Food CSD2007-00063 from the Spanish Ministry of Science and Innovation. Diego Muñoz-Provencio was recipient of a research fellowship from the Instituto Danone. Amalia Blasco is acknowledged for her excellent technical support. 


\section{CAPÍTULO 5}

\section{REFERENCES}

Bellon-Fontaine MR, J; vanOss, CJ (1996) Microbial adhesion to solvents: A novel method to determine the electron-donor/electronacceptor or Lewis acid-base properties of microbial cells Colloids and Surfaces $B$ : biointerfaces 7: 47-53.

Bonomo RA \& Rossolini GM (2008) Importance of antibiotic resistance and resistance mechanisms. Foreword. Expert Rev Anti Infect Ther 6: 549-550.

Bucher P, Karplus K, Moeri N \& Hofmann K (1996) A flexible motif search technique based on generalized profiles. Comput Chem 20: 3-23.

Clancy KW, Melvin JA \& McCafferty DG (2010) Sortase transpeptidases: insights into mechanism, substrate specificity, and inhibition. Biopolymers 94: 385396.

Crooks GE, Hon G, Chandonia JM \& Brenner SE (2004) WebLogo: a sequence logo generator. Genome Res 14: 1188-1190.

Cserzo M, Wallin E, Simon I, von Heijne $G$ \& Elofsson A (1997) Prediction of transmembrane alpha-helices in prokaryotic membrane proteins: the dense alignment surface method. Protein Eng 10: 673676.

Desvaux M, Dumas E, Chafsey I \& Hebraud M (2006) Protein cell surface display in Gram-positive bacteria: from single protein to macromolecular protein structure. FEMS Microbiol Lett 256: 1-15.
Dieye Y, Usai S, Clier F, Gruss A \& Piard JC (2001) Design of a proteintargeting system for lactic acid bacteria. J Bacteriol 183: 41574166.

Dieye Y, Oxaran V, Ledue-Clier F, et al. (2010) Functionality of sortase A in Lactococcus lactis. Appl Environ Microbiol 76: 7332-7337.

Dramsi S, Trieu-Cuot P \& Bierne H (2005) Sorting sortases: a nomenclature proposal for the various sortases of Gram-positive bacteria. Res Microbiol 156: 289-297.

Dramsi S, Magnet S, Davison S \& Arthur M (2008) Covalent attachment of proteins to peptidoglycan. FEMS Microbiol Rev 32: 307-320.

Elliot MA, Karoonuthaisiri N, Huang J, Bibb MJ, Cohen SN, Kao CM \& Buttner MJ (2003) The chaplins: a family of hydrophobic cell-surface proteins involved in aeria mycelium formation in Streptomyces coelicolor. Genes Dev 17: 1727-1740.

Foligne B, Nutten S, Grangette C, et al. (2007) Correlation between in vitro and in vivo immunomodulatory properties of lactic acid bacteria. World $J$ Gastroenterol 13: 236-243.

Goh YJ, Lee JH \& Hutkins RW (2007) Functional analysis of the fructooligosaccharide utilization operon in Lactobacillus paracasei 1195. Appl Environ Microbiol 73: 5716-5724.

Gross G, van der Meulen J, Snel J, et al. (2008) Mannose-specific interaction of Lactobacillus plantarum with porcine jejunal epithelium. FEMS Immunol Med Microbiol 54: 215-223. 


\section{CAPÍTULO 5}

Hendrickx AP, Budzik JM, Oh SY \& Schneewind O (2011) Architects at the bacterial surface - sortases and the assembly of pili with isopeptide bonds. Nat Rev Microbiol 9: 166-176.

Intra J, Pavesi G \& Horner DS (2008) Phylogenetic analyses suggest multiple changes of substrate specificity within the glycosyl hydrolase 20 family. BMC Evol Biol 8: 214.

Kankainen M, Paulin L, Tynkkynen S, et al. (2009) Comparative genomic analysis of Lactobacillus rhamnosus GG reveals pili containing a human- mucus binding protein. Proc Natl Acad Sci U S A 106: 17193-17198.

Kunji ER, Mierau I, Hagting A, Poolman B \& Konings WN (1996) The proteolytic systems of lactic acid bacteria. Antonie Van Leeuwenhoek 70: 187-221.

Leloup L, Ehrlich SD, Zagorec M \& MorelDeville F (1997) Single-crossover integration in the Lactobacillus sake chromosome and insertional inactivation of the ptsl and lacL genes. Appl Environ Microbiol 63: 2117-2123.

Mao H, Hart SA, Schink A \& Pollok BA (2004) Sortase-mediated protein ligation: a new method for protein engineering. J Am Chem Soc 126: 2670-2671.

Marchler-Bauer A, Lu S, Anderson JB, et al. (2011) CDD: a Conserved Domain Database for the functional annotation of proteins. Nucleic Acids Res 39 D225-229.

Maresso AW \& Schneewind O (2006) Iron acquisition and transport in
Staphylococcus aureus. Biometals 19: 193-203.

Maresso AW \& Schneewind O (2008) Sortase as a target of antiinfective therapy. Pharmacol Rev 60: 128-141.

Maresso AW, Chapa TJ \& Schneewind O (2006) Surface protein IsdC and Sortase B are required for hemeiron scavenging of Bacillus anthracis. J Bacteriol 188: 8145 8152

Marraffini LA \& Schneewind O (2006) Targeting proteins to the cell wall of sporulating Bacillus anthracis. Mol Microbiol 62 : 1402-1417.

Marraffini LA, Dedent AC \& Schneewind O (2006) Sortases and the art of anchoring proteins to the envelopes of gram-positive bacteria. Microbiol Mol Biol Rev 70: 192-221.

Maze A, Boel G, Poncet S, et al. (2004) The Lactobacillus casei ptsHI47T mutation causes overexpression of a LevR-regulated but RpoNindependent operon encoding a mannose class phosphotransferase system. $J$ Bacteriol 186: 4543-4555.

Maze A, Boel G, Zuniga M, et al. (2010) Complete genome sequence of the probiotic Lactobacillus casei strain BL23. J Bacteriol 192 2647-2648.

Mazmanian SK, Liu G, Ton-That H \& Schneewind O (1999) Staphylococcus aureus sortase, an enzyme that anchors surface proteins to the cell wall. Science 285: 760-763. 


\section{CAPÍTULO 5}

Monedero V, Gosalbes MJ \& PerezMartinez G (1997) Catabolite repression in Lactobacillus casei ATCC 393 is mediated by CcpA. $J$ Bacteriol 179: 6657-6664.

Munoz-Provencio D, Llopis M, Antolin M, de Torres I, Guarner F, PerezMartinez G \& Monedero V (2009) Adhesion properties of Lactobacillus casei strains to resected intestinal fragments and components of the extracellular matrix. Arch Microbiol 191: 153-161.

Parthasarathy R, Subramanian S \& Boder ET (2007) Sortase A as a novel molecular "stapler" for sequence-specific protein conjugation. Bioconjug Chem 18 469-476.

Popp MW, Antos JM, Grotenbreg GM, Spooner E \& Ploegh HL (2007) Sortagging: a versatile method for protein labeling. Nat Chem Biol 3: 707-708.

Posno M, Leer RJ, van Luijk N, van Giezen MJ, Heuvelmans PT, Lokman BC \& Pouwels PH (1991) Incompatibility of Lactobacillus Vectors with Replicons Derived from Small Cryptic Lactobacillus Plasmids and Segregational Instability of the Introduced Vectors. Appl Environ Microbiol 57: 1822-1828.

Pretzer G, Snel J, Molenaar D, et al. (2005) Biodiversity-based identification and functional characterization of the mannose-specific adhesin of Lactobacillus plantarum. $J$ Bacteriol 187: 6128-6136.

Sabet C, Lecuit M, Cabanes D, Cossart P \& Bierne H (2005) LPXTG protein InIJ, a newly identified internalin involved in Listeria monocytogenes virulence. Infect Immun 73: 6912-6922.

Scott JR \& Barnett TC (2006) Surface proteins of gram-positive bacteria and how they get there. Annu Rev Microbiol 60: 397-423.

Schaffer C \& Messner P (2005) The structure of secondary cell wall polymers: how Gram-positive bacteria stick their cell walls together. Microbiology 151: 643651.

Schluter S, Franz CM, Gesellchen F, Bertinetti O, Herberg FW \& Schmidt FR (2009) The high biofilm-encoding Bee locus: a second pilus gene cluster in Enterococcus faecalis? Curr Microbiol 59: 206-211.

Silhavy TJ, Kahne D \& Walker S (2010) The bacterial cell envelope. Cold Spring Harb Perspect Biol 2 a000414.

Snodgrass JL, Mohamed N, Ross JM, Sau S, Lee CY \& Smeltzer MS (1999) Functional analysis of the Staphylococcus aureus collagen adhesin B domain. Infect Immun 67: 3952-3959.

Strahinic I, Kojic M, Tolinacki M, Fira D \& Topisirovic L (2010) The presence of prtP proteinase gene in natural isolate Lactobacillus plantarum BGSJ3-18. Lett Appl Microbiol 50: 43-49.

Symersky J, Patti JM, Carson M, et al. (1997) Structure of the collagenbinding domain from a Staphylococcus aureus adhesin. Nat Struct Biol 4: 833-838.

Tendolkar PM, Baghdayan AS \& Shankar N (2006) Putative surface proteins encoded within a novel 


\section{CAPÍTULO 5}

transferable locus confer a highbiofilm phenotype to

Enterococcus faecalis. J Bacteriol 188: 2063-2072.

Ton-That H, Liu G, Mazmanian SK, Faull KF \& Schneewind $O$ (1999)

Purification and characterization of sortase, the transpeptidase that cleaves surface proteins of Staphylococcus aureus at the LPXTG motif. Proc Natl Acad Sci U S A 96: 12424-12429.

Tsukiji S \& Nagamune T (2009) Sortasemediated ligation: a gift from Gram-positive bacteria to protein engineering. Chembiochem 10: 787-798.

van Pijkeren JP, Canchaya C, Ryan KA, et al. (2006) Comparative and functional analysis of sortasedependent proteins in the predicted secretome of Lactobacillus salivarius UCC118. Appl Environ Microbiol 72: 41434153.

von Ossowski I, Satokari R, Reunanen J, et al. (2011) Functional characterization of a mucusspecific LPXTG surface adhesin from probiotic Lactobacillus rhamnosus GG. Appl Environ Microbiol.doi:10.1128/AEM.024 97-10

von Ossowski I, Reunanen J, Satokari R, et al. (2010) Mucosal adhesion properties of the probiotic Lactobacillus rhamnosus GG SpaCBA and SpaFED pilin subunits. Appl Environ Microbiol 76: 2049-2057 
DISCUSIÓN GENERAL

DISCUSIÓN GENERAL 
DISCUSIÓN GENERAL 


\section{DISCUSIÓN GENERAL Y CONCLUSIONES}

La capacidad de adherirse al epitelio, como se ha mencionado repetidamente a lo largo de esta tesis, condiciona la persistencia en el tracto gastrointestinal, posibilita la colonización, al menos transitoria, de las superficies mucosas y se considera un importante criterio de selección de cepas de bacterias acido lácticas con potencial probiótico.

Esta colonización facilitaría interacciones con otros miembros de la microbiota, con células epiteliales y con células del sistema linfoide asociado a mucosas; interacciones cruciales para el desempeño de los efectos beneficiosos sobre la salud del hospedador. Sin embargo la información acerca de los mecanismos y las moléculas implicadas es aún limitada para este grupo de microorganismos.

Lactobacillus casei es una especie presente de forma natural en los tractos gastrointestinales y reproductivos de humanos $y$ animales, tiene una larga historia de uso en la industria alimentaria y comprende múltiples cepas consideradas probióticas. La experiencia en su estudio en el Laboratorio de Bacterias Lácticas y Probióticos del IATA, junto con lo anteriormente mencionado, convirtieron a esta especie en un sujeto ideal para estudiar mecanismos de adhesión al epitelio intestinal y las moléculas implicadas.

En el capítulo 1: "Adhesion properties of Lactobacillus casei strains to resected intestinal fragments and components of the extracellular matrix", abordamos la cuestión de si el origen concreto de una cepa influye en su capacidad de adherirse a la mucosa del hospedador.

Estudiamos las propiedades de superficie y las capacidades adhesivas de una colección de cepas de $L$. casei que incluía aislados de productos alimentarios, aislados de origen humano y cepas comercializadas como probióticas. 
Ningún modelo para el estudio de las capacidades adhesivas de las bacterias lácticas refleja en su totalidad la complejidad del ambiente gastrointestinal. Por ello utilizamos varios modelos diferentes y determinamos diversos parámetros con el objeto de complementar la información obtenida y determinar el grado de correlación existente.

El test de adhesión a solventes (MATS) permite determinar las propiedades fisicoquímicas netas de hidrofobicidad y carga, importantes en las interacciones inespecíficas reversibles que inician los procesos de adhesión. La superficie de la práctica totalidad de las cepas estudiadas presenta un carácter no ácido mientras que el grado de hidrofobicidad es ampliamente variable.

En colaboración con la Unidad de Investigación del Sistema Digestivo del Hospital Universitario Vall d'Hebron se estudió la adhesión de la colección de cepas a explantes de tejido intestinal obtenido de pacientes sometidos a cirugía colónica. Tres cepas presentaron la capacidad de adhesión más elevada: BL23 (cepa de laboratorio), BL87 (aislada de cavidad oral) y BL227 (cepa probiótica comercial). Esto se correlacionó para las dos últimas con una elevada capacidad de unir mucina inmovilizada en inmunoplacas, mientras que esta capacidad fue muy baja e incluso indetectable para el resto de las cepas.

Ninguna cepa fue capaz de aglutinar levaduras. La aglutinación es común en cepas que producen adhesinas homólogas a Mub o Msa de Lactobacillus plantarum y Lactobacillus reuteri, dos proteínas multidominio que poseen actividad lectina específica de manosa y múltiples repeticiones en tándem (hasta 15 copias) del dominio de unión a mucus MucBP. El genoma de las cepas de L. casei secuenciadas, incluyendo BL23 y BL90 (ATCC334), no muestra proteínas homólogas a MapA o Msa con éstas repeticiones de dominios, que por otra parte son característicos de cepas de hábitat intestinal. Sin embargo, como se discutirá más adelante, las cepas de L. casei codifican en sus genomas proteínas que podrían estar implicadas en la adhesión a mucus. 


\section{DISCUSIÓN GENERAL}

Todas las cepas de la colección estudiada fueron capaces de unir en distinta medida colágeno, fibronectina o fibrinógeno inmovilizado en inmunoplacas. La adhesión a estas proteínas de matriz extracelular se ha estudiado ampliamente en patógenos, donde juega un papel esencial en la invasión y colonización del huésped en el proceso infeccioso. Es conocido que diversas cepas de Lactobacillus pueden adherirse a estas moléculas, aunque existe controversia sobre cuál puede ser el papel de esta adhesión, tanto en la colonización como en mecanismos de interferencia frente a patógenos.

No se encontró una relación clara entre las propiedades adhesivas y el origen de las cepas ni entre las capacidades adhesivas y la hidrofobicidad de superficie. La mayoría de las cepas estudiadas disminuyeron su capacidad de adhesión a los sustratos ensayados tras ser sometidas a tratamientos proteolíticos, lo que sugiere que la adhesión es mediada en parte por determinantes de tipo proteico expuestos en su superficie.

Este trabajo ha mostrado la alta variabilidad intra-específica de las propiedades de adhesión, la ausencia de perfiles de adhesión claros, la necesidad de evaluar individualmente cada caso y sugiere que la existencia de factores de adhesión está extendida en cepas de L. casei de distintos orígenes. Los resultados corroboran la extendida observación de que las propiedades de los probióticos son específicas de cepa, y no de especie.

Para estudios posteriores sobre la capacidad adhesiva de $L$. casei a proteínas de la matriz extracelular decidimos utilizar la cepa $L$. casei BL23 por varios motivos: esta cepa muestra propiedades probióticas in vitro y en modelos animales y comprobamos en este capítulo que se adhería a explantes colónicos ex vivo. A su vez, esta cepa ha sido ampliamente utilizada como modelo en diversos estudios del Laboratorio de Bacterias Lácticas y Probióticos, se contaba con herramientas para su manipulación genética y se disponía de información sobre su secuencia genómica que fue ampliándose a lo largo de esta tesis. 
Abordamos la caracterización de factores proteícos, ya que ésta presenta varias ventajas desde un punto de vista práctico:

- La purificación e identificación es metodológicamente más sencilla.

- Desde un punto de vista genético su estudio es más abordable mediante la construcción de mutantes simples.

- Existen multitud de proteínas identificadas como adhesinas en bacterias que colonizan mucosas, tanto patógenas como comensales.

- Por último, los ensayos con proteasas apuntaban a proteínas como el componente mayoritario responsable de las cualidades de adhesión.

Así pues, la identificación de factores proteicos se abordó mediante tres estrategias complementarias: el análisis in silico de la codificación en el genoma de posibles factores de adhesión, la utilización de la técnica de phage display y la identificación directa de proteínas con capacidad de unión a proteínas de matriz extracelular. Por último, se caracterizó la unión a la superficie celular de proteínas mediante mecanismos dependientes de sortasas en L. casei BL23.

En el capítulo 2: "Characterization of a fibronectin-binding protein from Lactobacillus casei BL23" analizamos la funcionalidad del gen fbpA de L. casei BL23 detectado durante un análisis in silico de factores de adhesión putativos codificados en su genoma. Esta proteína ha sido caracterizada como un factor de adhesión a fibronectina en estreptococos, homólogos a ella están codificados en los genomas de todos los lactobacilos presentes en bases de datos y el gen $f b p A$ y la proteína FbpA se detectaron en todas las cepas de $L$. casei analizadas aquí. 
Habíamos observado que L. casei era capaz de unir fibronectina inmovilizada y que esta característica era dependiente de proteínas de superficie. A su vez, se demostró que la proteína FbpA purificada de manera recombinante poseía esa capacidad de unión.

La construcción de un mutante de L. casei en $f b p A$ permitió estimar la participación de FbpA en la unión a fibronectina in vitro. Esta cepa mutante mostró un $50 \%$ de reducción en su capacidad de unir fibronectina, que se vio totalmente inhibida tras el tratamiento con proteasas. Esto sugiere la presencia de factores adicionales capaces de unir fibronectina, presumiblemente de naturaleza proteica y refuerza la idea de que la adhesión es un proceso multifactorial.

Mediante el uso de anticuerpos específicos contra FbpA pudimos determinar que parte de esta proteína se encuentra asociada a la superficie de $L$. casei. FbpA engruesa la lista de proteínas de localización extracelular que carecen de secuencia señal de secreción. Los efectos de la mutación en $f b p A$ sobre la superficie celular fueron claros: una acusada disminución de la hidrofobicidad. Sin embargo, y contrariamente a lo observado en un mutante $f b p A$ de la cepa Lactobacillus acidophillus NCIMB, los efectos de mutar fbpA en $L$. casei sobre la capacidad de adhesión a líneas celulares Caco-2 y HT-29 fueron mínimos. Posiblemente $L$. casei se sirva de mecanismos independiente de FbpA para unirse a las líneas celulares o la contribución de FbpA en estos modelos sea baja.

La mutación de $f b p A$ en otras bacterias produce disminución en la capacidad de unir fibronectina y efectos pleiotrópicos que difieren notablemente entre especies (desde cambios en las propiedades fisicoquímicas de superficie hasta disminución en los niveles de expresión de otros factores de adhesión). El papel exacto de FbpA no es conocido todavía. El que interaccione in vivo con fibronectina o module la expresión y funcionalidad de otras proteínas que interactúen con la misma se desconoce y requiere una mayor investigación. 
En el capítulo 3: "Shotgun phage display of Lactobacillus casei BL23 against collagen and fibronectin" empleamos la técnica de Shotgun Phage Display para tratar de identificar adhesinas de L. casei BL23 capaces de interaccionar con fibronectina y colágeno. Mediante esta técnica no se requiere información previa de la secuencia genómica de la especie a analizar y permite identificar factores de adhesión difíciles de reconocer en análisis in silico, ya que muchas adhesinas son proteínas moonlighting, por lo que es difícil inferir funciones de adhesión a partir de la predicción de su función primaria en la célula.

Frente a fibronectina se aislaron clones que expresaban fusiones del gen de la proteína pVIII del fago M13 con fragmentos del producto del gen LCABL_01820. Este gen codifica una proteína putativa de función desconocida, sin evidente señal de secreción, con homólogos tan solo en cepas de L. casei y L. rhamnosus.

Frente a colágeno se aislaron fusiones de $\mathrm{pVIII}$ con fragmentos del producto de LCABL_13470. Este gen se encuentra en una agrupación de genes de tipo profago y codifica una putativa endolisina fágica homóloga de la endolisina ps356 de Lactococcus lactis. La proteína contiene motivos probablemente implicados en unión a la pared celular (SH3 y LysM) y un dominio catalítico glicosil hidrolasa de la familia 25. Estos resultados poseen cierta lógica, ya que algunas endolisinas de pared de patógenos han sido descritas como factores de adhesión implicados en virulencia.

Finalmente, fusiones de pVIII con fragmentos del producto de LCABL_29260 se aislaron tanto frente a colágeno como frente a fibronectina. Este gen codifica un regulador transcripcional putativo de una fosfocetolasa ( $x p k$ ) codificada adyacentemente en el genoma por lo que su producto se pasó a denominar XpkR. La proteína pertenece a la familia DeoR de reguladores transcripcionales y cuenta con un dominio hélice-giro-hélice $(\mathrm{H}-\mathrm{T}-\mathrm{H})$ de unión a DNA en el extremo $\mathrm{N}$-terminal. Este generalmente controla la expresión de genes implicados en el catabolismo de azúcares y su presencia en los clones aislados apunta a este dominio como responsable de la unión. 


\section{DISCUSIÓN GENERAL}

La capacidad de unión de las proteínas identificadas se verificó a través de la construcción de diversas fusiones GST. Mediante esta herramienta se determinó que las proteínas purificadas tras su expresión en Escherichia coli retenían la capacidad de unirse a proteínas de la matriz extracelular, siendo todas ellas capaces de unir fibronectina, fibrinógeno y colágeno en cierta medida. Determinadas fusiones a GST perdieron la capacidad de unión, lo que pone de manifiesto la posible existencia de condicionantes estéricos para la interacción con los sustratos.

Pese a que fusiones a ps356 y al producto de LCABL_01820 se aislaron solo frente a fibronectina y colágeno, respectivamente, las tres proteínas identificadas son capaces de unirse a fibronectina, fibrinógeno y colágeno. Esta falta de especificidad de unión es característica de otros factores de adhesión de lactobacilos.

La técnica de phage display nos ha permitido identificar tres proteínas de $L$. casei BL23 con actividad de unión in vitro a proteínas de la matriz extracelular. La verdadera funcionalidad de estas proteínas en la adhesión in vivo se desconoce. Con la excepción de la endolisina ps356, éstas carecen de señales reconocibles de secreción. En algunos casos se ha descrito en otros microorganismos la presencia de reguladores transcripcionales en su proteoma de superficie, aunque el papel de esta localización se desconoce.

El análisis por RT-PCR evidenció la presencia de transcritos de los tres genes identificados bajo nuestras condiciones de laboratorio. Se obtuvieron anticuerpos frente a los productos de LCABL_01820 y $x p k R$, pero la presencia de estas proteínas en fracciones citoplasmáticas o extracelulares no pudo determinarse con precisión (resultados no mostrados). A pesar de que sus capacidades de adhesión in vitro quedaron demostradas en este trabajo, su funcionalidad en este aspecto es todavía discutible. Su estudio requeriría la construcción de mutantes específicos y la localización inequívoca de las proteínas en la superficie de L. casei. 
En el capítulo 4: "Identification of surface proteins from Lactobacillus casei BL23 able to bind fibronectin and collagen" utilizamos una tercera técnica para identificar proteínas de superficie de $L$. casei BL23 que interactuaran con proteínas de la matriz extracelular in vitro. Nuestros resultados muestran que una variedad de proteínas y enzimas de localización primaria citoplásmática podrían ejercer funciones relacionadas con la adhesión en esta bacteria.

Las proteínas identificadas se pueden englobar en 4 grupos funcionales:

- Proteínas implicadas en respuesta a estrés (ClpL y GroEL)

- Factores implicados en la elongación del péptido durante la síntesis proteica en el ribosoma (EF-Tu y EF-G)

- Proteínas de unión a soluto pertenecientes a transportadores $A B C$ putativamente implicados en captación de oligopéptidos (OppA1 y OppA2)

- Enzimas glicolíticas (enolasa y gliceraldehído 3-fosfato deshidrogenasa o GAPDH).

Salvo las proteínas de unión a soluto, que son lipoproteínas con una señal de anclaje covalente a membrana reconocible por la peptidasa señal II, el resto son proteínas citoplásmicas sin péptidos de secreción reconocibles.

La enolasa y GAPDH se purificaron como fusiones GST, las cuales fueron capaces de unir fibronectina y colágeno inmovilizados en inmunoplaca. Por tanto, al igual que el resto de proteínas identificadas en capítulos anteriores, las enzimas recombinantes retenían su capacidad de interaccionar con proteínas de la matriz extracelular. 
Para la mayoría de las proteínas identificadas en este capítulo se ha descrito su contribución a la adhesión bacteriana (unión a componentes del mucus, la matriz extracelular y a células epiteliales) en diversos microorganismos, desde patógenos a probióticos, incluidas varias especies de lactobacilos y bifidobacterias. Igualmente, para algunas de ellas se han sugerido roles en la interacción entre probióticos y el hospedador (inmunoregulación y activación del plasminógeno), por lo que podrían desempeñar un papel importante en la persistencia y fisiología de estas bacterias en los nichos de la mucosa.

La variedad de proteínas de superficie de L. casei identificadas en este trabajo capaces de interaccionar con componentes de la matriz extracelular refuerza las observaciones previas de que el proceso de adhesión es multifactorial. Es muy posible que la mayoría de estas proteínas posean características de tipo lectina, ya que las proteínas de la matriz extracelular y las mucinas se caracterizan por estar altamente modificadas, principalmente por glicosilación.

Es destacable que ninguna de las proteínas identificadas en los capítulos 2 y 3 haya sido encontrada aquí. Esto pone de manifiesto la necesidad de utilizar múltiples técnicas para identificar proteínas de adhesión, ya que ninguna técnica por separado posee la capacidad resolutiva suficiente y todas presentan limitaciones en la identificación.

Los datos obtenidos en este trabajo apuntan a que este grupo de organismos decora su superficie con proteínas capaces de unirse a un amplio espectro de sustratos de forma inespecífica. La manera por la cual estas proteínas "adhesivas" llegan a localizarse en la superficie sin la participación de las vías clásicas de secreción de proteínas en bacterias continúa suscitando controversia. 
En el capítulo 5: "Four sortase genes are present in the genome of Lactobacillus casei BL23. Mutant construction and characterization.", estudiamos la presencia de enzimas sortasas y sus sustratos en L. casei BL23, con la finalidad de determinar su contribución a las propiedades adhesivas de esta cepa. Mediante este análisis pretendíamos estudiar un grupo de proteínas cuya localización primaria es la superficie celular y para las cuales se han descrito funciones de adhesión e interacción con componentes de la matriz extracelular y mucosa en otros grupos bacterianos.

Un análisis bioinformático permitió identificar cuatro genes que codificaban enzimas sortasas en su genoma. Estas enzimas son las encargadas del anclaje covalente al peptidoglicano de proteínas que presentan motivos LPxTG en su porción C-terminal. Dos sortasas pertenecían a la clase $\mathrm{A}$ (sortasas generales) y dos a la clase $\mathrm{C}$, que pasamos a denominar srtA1, srtA2, srtC1 y srtC2 respectivamente.

Las sortasas de clase $\mathrm{C}$ se localizan en agrupaciones con sus sustratos potenciales. Los clusters srtC1 y srtC2 contienen genes homólogos a los clusters spaFED y spaCBA de L. rhamnosus GG, respectivamente, responsables de la formación de estructuras extracelulares tipo pili.

En total se pudieron identificar 23 sustratos putativos cuyo motivo reconocible por sortasas no se diferenciaba notablemente del consenso LPxTG. Estos sustratos se dividen a partes iguales entre los que codifican proteínas putativas con función desconocida, los que codifican enzimas (proteasas y glicosidasas) y aquellos que codifican proteínas presumiblemente relacionadas con adhesión.

La construcción tanto de mutantes simples en cada una de las cuatro sortasas como de un doble mutante srtA1/srtA2 nos permitió evaluar su papel en el anclaje de proteínas en superficie, así como su efecto en la adhesión. El mutante srtA1 mostró una notable disminución de la hidrofobicidad de superficie, pero fue necesario el uso del doble mutante srtA1/srtA2 para observar cambios sustanciales en la localización en superficie de proteínas LPXTG propias (proteinasa PrtP y $\mathrm{N}$-acetil-glucosaminidasa) y heterólogas (fusión Nuc::CWA). 
Por otra parte, los ensayos de adhesión mostraron que, una vez más, el mayor efecto tanto en adhesión a las líneas celulares Caco-2 y HT-29 como a algunas proteínas de matriz extracelular se encontraba para el mutante srtA1/srtA2.

La presencia de dos genes de sortasas generales (srtA1 y srtA2) resulta un hecho destacable. Un análisis por RT-PCR permitió determinar que srtA1 y las dos sortasas de la clase $C$ (srtC1 y srtC2) se expresaban bajo nuestras condiciones de laboratorio. Por su parte la expresión de srtA2 es indetectable y sólo se hacía aparente en el mutante con la disrupción de srtA1, estando el mecanismo responsable de este fenómeno todavía por determinar.

Todos los resultados expuestos apuntan a que srtA1 actúa como la sortasa constitutiva responsable de anclar a pared la mayoría de los sustratos con motivo reconocible por sortasas y que srtA2 podría desempeñar un papel redundante y complementario que pasa a ser esencial con la ausencia de srtA1.

Este trabajo ha dejado patente que algunas de las proteínas LPXTG de L. casei BL23 pueden jugar un papel en la adhesión. Es remarcable el hecho de la presencia de los clusters spaFED y spaCBA junto con las sortasas srtC1 y srtC2, que en L. rhamnosus GG son responsables de la formación de pili adhesivos para mucus. Estos dos clusters, o al menos uno de ellos, están presentes en todas las cepas de $L$. casei/rhamnosus analizadas, lo cual los convierte en una característica para este grupo que no ha sido descrita en ningún otro lactobacilo.

Por otro lado, el gen LCABL_25040 de L. casei BL23, que codifica un sustrato de sortasas, es homólogo a LGG_02337 de L. rhamnosus GG, que codifica una proteína con capacidad de adhesión a mucus. Esta proteína es la única de $L$. casei BL23 que posee tres dominios MucBP, aunque no es homóloga a adhesinas de mucus del tipo MapA o Msa. Nuestros experimentos evidenciaron que L. casei BL23 no muestra prácticamente adherencia a mucina de origen gástrico de cerdo (capítulo 1 ), mientras que L. rhamnosus GG es una bacteria cuya adherencia a mucus intestinal humano está ampliamente probada. 
La posible participación de los genes responsables de la síntesis de pili y de LCABL_25040 en la adhesión de L. casei BL23 a mucus merece un estudio más profundo. 


\section{CONCLUSIONES FINALES}

1. En L. casei la capacidad de adhesión al epitelio intestinal y a proteínas de la matriz extracelular es ampliamente variable entre cepas, sin apreciarse patrones de adhesión ligados al origen. El proceso de adhesión es multifactorial y la contribución a esta capacidad es mayoritariamente proteica.

2. Las distintas metodologías empleadas para identificar proteínas de adhesión en $L$. casei BL23 han aportado resultados no coincidentes. Esto pone de manifiesto la necesidad de emplear técnicas diferentes para llegar a identificar todo el repertorio de adhesinas. Los resultados obtenidos mediante técnicas exclusivamente in vitro, como el phage display, deberían validarse mediante la construcción de mutantes, la purificación de proteínas y el análisis in vitro e in vivo.

3. Se han identificado varias proteínas de L. casei BL23 que poseen capacidad de adhesión a componentes de la matriz extracelular. Entre ellas cabe destacar enzimas de localización primaria citoplasmática, como la GAPDH y la enolasa, o proteínas como FbpA, para la cual no se determinado todavía su papel preciso en la adhesión. En general, los resultados son coincidentes con la identificación de factores de adhesión en otras especies de lactobacilos. El mecanismo por el cual muchas de estas proteínas son transportadas hasta y retenidas en la pared celular se desconoce todavía y requiere una mayor investigación.

4. En L. casei BL23 existen numerosas proteínas de superficie ancladas mediante mecanismos dependientes de sortasa. Estas pueden ser clasificadas en tres categorías: enzimas implicados en la utilización de moléculas de la mucosa del huésped, proteínas posiblemente implicadas en adhesión y proteínas de función desconocida. Este hecho, junto con los experimentos de adhesión utilizando mutantes en genes de sortasas, indica que 


\section{DISCUSIÓN GENERAL}

un porcentaje alto de las proteínas ancladas covalentemente a la pared celular de L. casei BL23 están relacionadas con la adaptación y modo de vida en el nicho gastrointestinal.

5. La presencia de dos genes codificando sortasas de tipo A y los resultados con los diversos mutates construidos indican que $L$. casei BL23 posee actividades sortasa redundantes. Es de destacar la existencia de sortasas especializadas asociadas a la formación de estructuras tipo pili, que podrían intervenir en los mecanismos de adhesión a las mucosas y constituyen una característica diferencial del grupo L. casei/L. rhamnosus. 